BRUNO VINÍCIUS MANZOLLI RODRIGUES

\title{
VALORIZAÇÃO DE FIBRAS DE SISAL: SÍNTESE DE ÉSTERES DE CELULOSE E PREPARAÇÃO DE MATERIAIS
}

Tese apresentada ao Instituto de Química de São Carlos, da Universidade de São Paulo, como parte dos requisitos para obtenção do título de Doutor em Ciências.

Área de Concentração: Físico-Química

Orientadora: Profa. Dra. Elisabete Frollini

São Carlos

2014 

Dedico este trabalho a minha família, por me apoiar incondicionalmente em tudo na vida. 



\section{Agradecimentos}

À Prof. Dra. Elisabete Frollini, pela dedicação na orientação concedida a mim durante todos os anos de trabalho. Pelo incentivo, confiança e preocupação com a minha formação pessoal, acadêmica e profissional.

A minha mãe, Tânia, e irmã, Isabela, por todo o esforço, incentivo e carinho durante todos estes anos, não importando a distância.

A Rachel, minha namorada e antes de tudo melhor amiga e companheira desde o todo o sempre. Agradeço por estar ao meu lado em todos os momentos e ser a melhor pessoa que já conheci em toda a minha vida.

Aos meus companheiros, amigos de laboratório, de curta ou longa data: Jorge, Tonimar, Fernando, Adriana, Talita, Daniele, Anderson, Bianca, Elaine, Érika, Daiana, Joice, Lilian, Daniela, Virgínia, Danilo, Andrea e Willian.

Ao Prof. Dr. Sérgio Campana, por agregar um grande valor ao "Grupo de Pesquisa Virtual" que envolve todos os integrantes do Grupo MacromoLignoCell e do Grupo de Físico-Química Orgânica.

Ao Prof. Dr. Pedro Fardim pela orientação e ensinamentos durante o período que estive sob sua orientação na Åbo Akademi University (Turku, Finlândia).

Aos amigos e companheiros de laboratório que fiz durante a minha jornada na Finlândia: Joanna, Beatriz, Kostya, Olga, Jan e Elina.

Aos meus amigos de longa data e vida, os quais foram fundamentais para sanar parte da alienação envolvida durante a realização deste trabalho: Olivis, Matheus, Bruno, André, Raphael e Vagner.

Aos funcionários do Instituto de Química de São Carlos presentes na Central de Análises Químicas (CAQI), na Biblioteca Prof. Johanes Rüdiger Lechat, no Serviço de PósGraduação, no Setor Financeiro e nas Oficinas: Mecânica, Eletrônica e Vidraria, por todos os serviços prestados. Meus especiais agradecimentos aos funcionários: Bernadete L. C. B. Figueiredo Filho, Márcia Zambon, Dr. Luiz Antônio Ramos e Dr. Márcio de Paula.

À FAPESP pelo suporte financeiro e bolsa concedida e ao CNPq e CAPES pelo suporte financeiro. 

"You've got to find what you love (...)

Your work is going to fill a large part of your life,

and the only way to be truly satisfied is to do what you believe is great work.

And the only way to do great work is to love what you do.

If you haven't found it yet, keep looking. Don't settle."

Steve Jobs (Stanford, 2005) 

Resumo $O$ presente trabalho visou à valorização da fibra lignocelulósica de sisal, focando principalmente em seu componente majoritário, a celulose, através da síntese de ésteres de celulose e também na preparação de diferentes materiais. A escolha dessa fonte lignocelulósica deveu-se a sua disponibilidade no país, sendo ○ Brasil ○ maior produtor e exportador mundial, e por se tratar de uma fonte de fibras com alto teor de celulose e de curto ciclo de crescimento. A síntese de ésteres de celulose com diferentes tamanhos de cadeia (acetatos, butanoatos e hexanoatos) e grau de substituição (GS) foi explorada, em meios homogêneo e heterogêneo, visando à identificação de condições que levassem aos melhores rendimentos. Em meio homogêneo, utilizando DMAc/LiCl como sistema de solvente e anidridos ácidos como agentes esterificantes, a síntese de ésteres de celulose com diferentes tamanhos de cadeia e GS $(0,2-3,0)$ foi possível, apenas ajustando-se a razão $\mathrm{Mol}_{\text {Anidrido }} / \mathrm{Mol}_{\text {Celulose }}$ Em meio heterogêneo, diferentes rotas de síntese foram exploradas. Com o uso do sistema anidrido ácido/iodo metálico (catalisador), apenas ésteres de cadeia curta (acetatos) puderam ser obtidos com alta eficiência. $\mathrm{Na}$ busca de rotas alternativas para a obtenção de ésteres de cadeias mais longas, o uso de cloreto ácido e piridina (como meio reacional e como catalisador nucleofílico, respectivamente) levou à obtenção de butanoatos de celulose completamente substituídos, em apenas 30 minutos. Posteriormente, os ésteres de celulose, preparados em meio homogêneo, foram considerados como materiais de partida na preparação de filmes e biocompósitos [ésteres de celulose/celulose (0-20\%)], também utilizando $\mathrm{DMAc/LiCl}$ como sistema de solvente. Os resultados de análise dinâmicomecânica (DMA) e ensaios de tração revelaram que, de modo geral, a introdução de celulose levou a biocompósitos com propriedades superiores em relação aos filmes sem celulose. Resultados superiores de módulo de armazenamento e resistência à tração foram obtidos com a consequente geração de materiais que apresentaram valores superiores de Módulo de Tração e menor alongamento na ruptura. Por exemplo, biocompósitos a partir de butanoato de celulose (GS I,8) com $20 \%$ de celulose mostraram valor de módulo de armazenamento (675 MPa) quase 4x maior que o mesmo filme sem reforço (195 MPa). Para os filmes a partir de hexanoatos de celulose (GS I,8), a adição de celulose aumentou a resistência à tração em até I unidade (I5\% de celulose), em relação ao filme sem reforço. Por meio do uso de técnicas avançadas de caracterização de superfície (XPS e ToF-SIMS), pôde-se estudar a distribuição dos grupos ésteres nas superfícies dos filmes, assim como a influência da variação do tamanho da cadeia do éster, GS e da presença da celulose nesta distribuição. Em linhas gerais, quando a cadeia lateral manteve-se constante (butanoatos), os 
resultados de XPS revelaram um aumento na contribuição do carbono alifático com o aumento do GS. Em relação à cobertura superficial por cadeias alifáticas dos grupos ésteres, os resultados de XPS indicaram uma maior concentração de celulose na superfície da matriz do biocompósito preparado a partir de acetato de celulose. Por outro lado, para os ésteres de cadeias maiores (butanoatos e hexanoatos de celulose), os resultados de XPS apontaram que a celulose estaria majoritariamente presente nas camadas mais internas, gerando um maior recobrimento da superfície dos biocompósitos pelos grupos ésteres da matriz. De acordo com os dados de ToF-SIMS, os grupos ésteres se distribuíram de maneira uniforme ao longo das superfícies dos filmes e biocompósitos. Posteriormente, após uma exploração de diversas condições de pré-tratamento na massa celulósica, as quais visaram condições ótimas para a dissolução da celulose em sistema aquoso de $\mathrm{NaOH} /$ Uréia e posterior coagulação em meio ácido, microesferas de celulose de sisal foram preparadas com sucesso. Essas microesferas de celulose apresentam potencialidade de aplicação em diversas áreas, como na liberação controlada de fármacos e cromatografia. $\mathrm{Na}$ etapa final, a fibra lignocelulósica e a celulose de sisal foram consideradas como materiais de partida em um estudo envolvendo a técnica de eletrofiação a temperatura ambiente, utilizando ácido trifluoroacético (TFA) como solvente. A partir do uso dessa técnica, a dissolução da fibra lignocelulósica e sua posterior reconstrução levou a formação de fibras ultrafinas (I 20 a 5 I 0 $\mathrm{nm})$. A eletrofiação da celulose de sisal levou a formação de fibras ultrafinas e nanofibras $(<100 \mathrm{~nm})$, em um amplo intervalo de diâmetros, apenas ajustando-se a vazão da solução. Os resultados obtidos neste trabalho abrem uma vasta gama de possíveis aplicações, nas quais as fibras ultrafinas e nanofibras, preparadas a partir da biomassa lignocelulósica, podem ser empregadas, tais como membranas, filmes em estruturas do tipo sanduíche ou mesmo como reforço em compósitos. Através do presente trabalho, diferentes tipos de materiais foram preparados, a partir da fibra lignocelulósica e da celulose de sisal, ampliando as possibilidades de aplicação destes materiais em diversas áreas.

Palavras-chave fibra lignocelulósica de sisal; celulose de sisal; ésteres de celulose; biocompósitos; microesferas; XPS; ToF-SIMS; eletrofiação 
Abstract The present investigation aimed at the valorization of the lignocellulosic sisal fiber, mainly focusing on its main component, i.e. cellulose, through the synthesis of cellulose esters and preparation of different materials. This lignocellulosic source was chosen due to its availability in the country since Brazil is the largest producer and exporter worldwide and also because this lignocellulosic source has a high cellulose content and a short life cycle. The synthesis of cellulose esters with varied chain lengths (acetates, butanoatos and hexanoates) and degree of substitution (DS) was explored in homogeneous and heterogeneous media in order to identify the conditions that led to better yields. In the homogeneous medium, by using $\mathrm{DMAc} / \mathrm{LiCl}$ as the solvent system and acid anhydrides as the esterifying agents, the synthesis of cellulose esters with varied chain lengths and DS (0.2-3.0) was possible by only adjusting the $\mathrm{Mol}_{\text {Anhydride }} / \mathrm{Mol}_{\text {Cellulose }}$ ratio. In the heterogeneous medium, different synthesis routes were explored. By using acid anhydride/metallic iodine (catalyst) as the system, only short-chain cellulose esters (acetates) could be obtained with high efficiency. In the search for new routes to obtain cellulose esters with longer chains, completely substituted esters (GS 3.0) were obtained by using acid chloride and pyridine (as the reaction medium and nucleophilic catalyst) in just 30 minutes. Afterwards, by using the same solvent system $(\mathrm{DMAc} / \mathrm{LiCl})$, cellulose esters prepared in a homogeneous medium were used as starting materials in the preparation of films and biocomposites [cellulose ester/cellulose $(0-20$ $w t \%)]$. The results of dynamic-mechanical analysis (DMA) and tensile tests revealed that, in general, the cellulose loading led to biocomposites with superior properties than the films without cellulose. Thus, higher values of storage modulus and tensile strength were obtained, which consequently led to materials with higher Young Modulus and lower elongation at break. For example, biocomposites from cellulose butanoate (GS I.8) with 20 wt\% of cellulose showed a storage module value $(675 \mathrm{MPa})$ almost 4 times higher than the film without cellulose (195 MPa). For the cellulose biocomposites from cellulose hexanoate (GS I.8), the cellulose loading increased the tensile strength up to I unit (I5 wt\% cellulose) comparatively to the film without cellulose. By means of advanced techniques of surface characterization (XPS and ToF-SIMS), the distribution of the cellulose ester groups along the films/biocomposites surfaces were studied as well as the influence of the different cellulose esters chain lengths, DS and presence of cellulose on that distribution. XPS results revealed an increase in the contribution of the aliphatic carbon as the DS increased when the side chain remained constant (butanoates). Regarding the surface coverage by aliphatic chains of the ester groups, XPS results indicated a higher concentration of cellulose on the surface of 
the biocomposite prepared from cellulose acetate as its matrix. Conversely, for the cellulose esters with longer chains (butanoates and hexanoates), XPS results pointed that the cellulose was mostly present in the inner layers, which generated a higher surface coverage of these biocomposites' surfaces by the aliphatic chains of the ester groups. According to the ToFSIMS results, the esters groups were evenly distributed on the surface of the films and biocomposites. Thereafter, beads from sisal cellulose were successfully prepared after an exploration of various pre-treatment conditions on the cellulosic mass, where optimal conditions were found to lead to complete cellulose dissolution in $\mathrm{NaOH} / \mathrm{Urea}$ aqueous system followed by coagulation in acid medium. Cellulose beads present a high potential of application in several areas, for example in controlled drug delivery and chromatography. At the final stage of this work, the lignocellulosic sisal and sisal cellulose fibers were used as starting materials in a study involving the electrospinning technique at room temperature, by using trifluoroacetic acid (TFA) as solvent. Through this technique, the lignocellulosic fiber dissolution and later reconstruction led to ultrathin fibers (I20 to $510 \mathrm{~nm})$. The electrospinning of sisal cellulose led to ultrathin fibers and nanofibers $(<100 \mathrm{~nm})$ in a wide interval of diameters, by only varying the solution flow rate. The results obtained in this investigation open a wide range of possible applications, in which the ultrathin and nanofibers prepared from the lignocellulosic biomass can be used, such as membranes, sandwich-type structure of films or as reinforcement in composite materials. Through the present work, different materials were prepared from the lignocellulosic sisal and sisal cellulose fibers, which contributed to expand the possibilities of application of these materials in diverse areas.

Keywords lignocellulosic sisal fiber; sisal cellulose; cellulose esters; biocomposites; beads; XPS; ToF-SIMS; electrospinning 


\section{Lista de Figuras}

Figura I - Representação da estrutura de uma fibra lignocelulósica e seus principais componentes.

Figura 2 - Estrutura da celulose.

Figura 3 - Representação das ligações hidrogênio intermoleculares e intramoleculares na estrutura cristalina da celulose.

Figura 4 - Composição de açúcares presentes na massa de hemicelulose seca da fibra lignocelulósica de sisal.. 39

Figura 5 - Estruturas químicas das unidades de açúcares presentes nas hemiceluloses. 40

Figura 6 - Alcoóis precursores nas reações de formação da lignina. 41

Figura 7 - Conceito estrutural da lignina de faia de acordo com NIMZ (1974). 42

Figura 8 - Foto de uma plantação de sisal. 43

Figura 9 - Produção de sisal (toneladas) e valores brutos de produção (US\$), no período de 200I-20II, no Brasil e no mundo.

Figura 10 - Comparativo da produção de sisal (toneladas) entre ○ Brasil e países com produção abaixo da média em relação aos valores brutos de mercado (US\$/tonelada), no período de 200I-20II 45

Figura II - Representação esquemática dos tipos de não uniformidade na derivatização da celulose.

Figura 12 - Projeções das celas unitárias da celulose no plano a, b: a) celulose I b) celulose II ----- ligações hidrogênio .58

Figura 13 - Esquemas de mecanismos propostos para o complexo [Li-DMAc] ${ }^{(+)} \mathrm{Cl}^{(-)} /$celulose $^{-}$

Figura 14 - Mecanismo de dissolução da celulose no sistema de solvente DMAc/LiCl proposto por ZHANG, C. et al. (20I4)..

Figura 15 - Analisador de fibras (MorFi Compact - Techpap).

Figura 16 - Representação esquemática das etapas do processo de solubilização da celulose.

Figura 17 - Modelo do sistema de acetilação da celulose em meio heterogêneo. A) banho de óleo; B) Balão de nitrogênio; C) Condensador de refluxo; D) Agitador mecânico. .73 
Figura 18 - Mapas de densidade da distribuição de comprimento/espessura das fibras de celulose de sisal e de celulose de sisal mercerizada.

Figura 19 - Espectros na região do infravermelho para as amostras de celulose de sisal e celulose de sisal mercerizada.

Figura 20 - Difratogramas de raios $X$ das amostras de celulose de sisal e celulose de sisal mercerizada.

Figura 2l - Teores de xilose/furfural e glicose/HMF advindos da hidrólise da polpa de celulose de sisal mercerizada.

Figura 22 - Fotomicrografias da celulose de sisal ampliada (a) 1000x e (b) 10.000; celulose de sisal mercerizada ampliada (c) 1000x e (d) 5.000x

Figura 23 - Curva TG da celulose de sisal (a) e celulose de sisal mercerizada (b), com respectiva $I^{\circ}$ derivada $(\mathrm{dTG})$, (atmosfera de $\mathrm{N}_{2}$, razão de aquecimento de $\left.20^{\circ} \mathrm{C} \mathrm{min}^{-1}\right) \ldots . . . .86$ Figura 24 - Reações de eliminação de água na celulose durante a decomposição térmica. ....88 Figura 25 - Estrutura da levoglucosana.

Figura 26 - Espectro de RMN-'H para um acetato de celulose obtido a partir de celulose de sisal mercerizada, com as áreas de integração delimitadas.

Figura 27 - Espectro de RMN-'H para um butanoato de celulose obtido a partir de celulose de sisal mercerizada, com as áreas de integração delimitadas.

Figura 28 - Espectro de RMN-'H para um hexanoato de celulose obtido a partir de celulose de sisal mercerizada, com as áreas de integração delimitadas.

Figura 29 - Dependência do grau de substituição com a razão $\mathrm{Mol}_{\text {Anidrido }} / \mathrm{Mol}_{\text {UAG }}$ para os ésteres de sisal obtidos em meio homogêneo (4 h de reação).

Figura 30 - Difratograma de raios $X$ da celulose de sisal mercerizada e acetato de celulose de sisal (GS 2,9).

Figura 3 I - Difratograma de raios $X$ para a celulose mercerizada e seus ésteres de cadeia longa.

Figura 32 - Difratograma de raios $X$ para os butanoatos de celulose obtidos em meio homogêneo.

Figura 33 - Difratogramas de raios $X$ para os hexanoatos de celulose obtidos em meio homogêneo.

Figura 34 - Curva TG e derivada primeira para o acetato de celulose de GS = 0,7 (atmosfera de $\mathrm{N}_{2}$, e razão de aquecimento de $20^{\circ} \mathrm{C} \mathrm{min}^{-1}$ ). 
Figura 35 - Mecanismo proposto para a reação de acetilação da celulose com anidrido acético, na presença de iodo como catalisador.

Figura 36 - Modelo gráfico da dependência dos GS com o tempo de reação para acetatos de celulose de sisal obtidos em meio heterogêneo.

Figura 37 - Mecanismo proposto para a reação de acilação da celulose com cloreto de butanoíla, na presença de piridina como catalisador nucleofílico. 107

Figura 38 - Mecanismo proposto para a reação de acilação da celulose com anidrido butanóico, na presença de piridina como catalisador nucleofílico 110

Figura 39 - Estágio de dissolução de um polímero, (A) rede com cadeias associadas e regiões interligadas, (B; C; D, E) estágio intermediário e $(F)$ completamente dissolvido. 116

Figura 40 - Modelo de "micela franjada" para os agregados de celulose em DMAc/LiCl ..... I I7 Figura 4 I - Esquema de preparação dos filmes e biocompósitos a partir de soluções de DMAc/LiCl - (a) solução transparente a partir da dissolução do éster de celulose/celulose em DMAc/LiCl (24 h, sob agitação mecânica); (b) filtração da solução seguida de deposição em placas de petri e formação de material com consistência de gel; (c) lavagem dos matérias obtidos até eliminação do sistema de solvente; (d) filmes secos em estufa.

Figura 42 - Micrografias das superfícies dos filmes de (a) celulose de sisal mercerizada, (b) acetato de celulose (GS I,8) e (c) biocompósito a partir de acetato de celulose GS I,8 e celulose de sisal (20\%).

Figura 43 - Micrografias das superfícies dos filmes/biocompósitos preparados a partir de butanoatos de celulose com (a) GS 0,7; (b) GS 0,7 e 20\% de celulose; (c) GSI,4; (d) GS I,4 e $20 \%$ de celulose; (e) GS I,8 e (f) GS I,8 e $20 \%$ de celulose.

Figura 44 - Micrografias de cortes transversais dos biocompósitos preparados a partir de butanoatos de celulose de (a) GS 0,7 e (b) GS 0,7 e celulose de sisal (20\%). 132

Figura 45 - Micrografias das superfícies para os filmes/biocompósitos preparados a partir de hexanoatos de celulose de (a) GS I,8; (b) GS I,8 e 12,5\% de celulose de sisal; (c) GS I,8 e $20 \%$ de celulose de sisal; (d) GS I,8 e I5\% de celulose de sisal.

Figura 46 - Difratograma de raios $X$ para os filmes/biocompósitos a partir de butanoatos de celulose com (a) GS 0,7; (b) GS I,4 e (c) GS I,8. 135 Figura 47 - Difratograma de raios x para os filmes/biocompósitos a partir de hexanoatos de celulose de GS I,0, GS I,8 e celulose de sisal...... 137

Figura 48 - Módulo de armazenamento, a 30, para $\circ$ filme de celulose de sisal e filmes/biocompósitos a partir de ésteres de celulose e celulose de sisal. 
Figura 49 - Temperatura de transição vítrea para os filmes/biocompósitos preparados a partir de (a) acetato de celulose; (b) butanoatos de celulose; (c) hexanoatos de celulose... 143 Figura 50 - Resistência à tração, a $30^{\circ} \mathrm{C}$, para os filmes/biocompósitos a partir de ésteres de celulose e celulose de sisal.

Figura $5 \mathrm{I}$ - Alongamento na ruptura, a $30^{\circ} \mathrm{C}$, para os filmes/biocompósitos a partir de ésteres de celulose e celulose de sisal.

Figura 52 - Valores de módulo de tração, a $30^{\circ} \mathrm{C}$, para os filmes/biocompósitos a partir de ésteres de celulose e celulose de sisal. .148

Figura 53 - Esquema adaptado do princípio de funcionamento de FE-SEM. 153

Figura 54 - Princípio de funcionamento da técnica de XPS.

Figura 55 - Princípio de funcionamento da técnica de ToF-SIMS .156

Figura 56 - Representação esquemática da superfície dos filmes e a área detectável via XPS.

Figura 57 - Variação na (a) razão $\mathrm{O} / \mathrm{C}$ e (b) $\mathrm{Cl}$ para os filmes de ésteres de celulose. 163

Figura 58 - Razões O/C para os filmes de ésteres de celulose e seus respectivos biocompósitos ( $20 \%$ de celulose). .164

Figura 59 - Variação em Cl e C2 para os biocompósitos. 165

Figura 60 - Cobertura superficial por cadeias alifáticas (grupos ésteres) para os filmes de butanoatos de celulose de diferentes GS e filmes de ésteres de celulose com diferentes tamanhos de cadeia (acetato; butanoato e hexanoato) com GS I,8. 165

Figura $6 \mathbf{I}$ - Cobertura superficial por cadeias alifáticas (grupos ésteres) para os filmes de ésteres de celulose com GS I,8 e seus respectivos biocompósitos ( $20 \%$ de celulose). 166 Figura 62 - Distribuições de grupos acetato (a) e (b) e hexanoatos (c) e (d) nas amostras Acl,8 e Hexl,8, em modo positivo. Imagens de íons totais. Área varrida: 200x $200 \mu \mathrm{m}^{2}$ (a) e (c) e $100 \times 100 \mu \mathrm{m}^{2}$ (b) e (d).

Figura 63 - Espectros de massa ToF-SIMS de íons negativos no intervalo de 30-I30 Da para os filmes Acl,8 e Hexl,8, coletados em uma área de varredura de $200 \times 200 \mu \mathrm{m}^{2}$. 168 Figura 64 - Distribuições de grupos acetato (a) e (b) e hexanoatos (c) e (d) nas amostras Acl,8 e Hexl,8, em modo negativo. Imagens de íons totais. Área varrida: $200 \times 200 \mu \mathrm{m}^{2} . . .169$ Figura 65 - Distribuições de grupos hexanoatos em Hexl,8/20Cel, mapeando o íon positivo $99 \mathrm{Da}$ (imagem de íons totais). Área varrida: $200 \times 200 \mu \mathrm{m}^{2}$ (a) e $100 \times 100 \mu \mathrm{m}^{2}(\mathrm{~b})$. 169 Figura 66 - Ângulo de contato em função do tempo: (a) filme de celulose e filmes de ésteres de celulose (GS I,8); (b) filmes de butanoatos de celulose com diferentes GS $(0,7-I, 8)$ e (c) 
filme de celulose e filmes de ésteres de celulose com GS I,8 e seus respectivos biocompósitos ( $20 \%$ de celulose).

Figura 67 - Microesfera de celulose.

Figura 68 - Representação esquemática da formação de complexos entre de hidratos de $\mathrm{NaOH}$ - hidratos de uréia - água livre - celulose na dissolução da celulose

Figura 69 - Esquema geral da dissolução da celulose e posterior regeneração na forma de microesferas via extrusão da solução, a partir de seringa, em banho coagulante ácido. 188

Figura 70 - Micrografias das superfícies das microesferas de celulose de sisal e celulose microcristalina preparadas em $\mathrm{NaOH}_{(\mathrm{aq} .)} /$ Uréia e coagulados em diferentes concentrações de $\mathrm{HNO}_{3}$.

Figura 7I - Micrografias das superfícies das microesferas de celulose de sisal e celulose microcristalina preparadas em $\mathrm{NaOH}_{(\text {aq.) }}$ /Uréia e coaguladas em diferentes temperaturas em $\mathrm{HNO}_{3} 4 \mathrm{M}$

Figura 72 - Efeito de diferentes velocidades de centrifugação na área, volume e índice de circularidade das microesferas de celulose de sisal. .201

Figura 73 - Diagrama esquemático mostrando algumas formas para nano-objetos................206

Figura 74 - Termos padrões utilizados para nanomateriais celulósicos (ISO/TS 27687).......207

Figura 75 - Equipamento utilizado no processo de eletrofiação .210

Figura 76 - Número de trabalhos publicados e indexados na base de dados SCOPUS no período de 1993 a 201 I contendo "electrospinning” como palavra-chave.

Figura 77 - Divisão dos trabalhos publicados por área de publicação, no período de 19942014, para o termo "electrospinning" na base de dados SCOPUS.

Figura 78 - Representação esquemática do funcionamento da técnica de eletrofiação .212 Figura 79 - Espectros de FTIR-ATR para a LSF de partida e eletrofiada (a) e ampliação na região de $2200-600 \mathrm{~cm}^{-1}$ (b).

Figura 80 - Principais componentes de uma fibra lignocelulósica: sítios reativos suscetíveis à esterificação pelo TFA.

Figura 8 I - Espectros de FTIR-ATR para SP de partida e eletrofiada (a) e ampliação na região de $2200-600 \mathrm{~cm}^{-1}$ (b) .225

Figura 82 - Micrografias das fibras obtidas a partir da eletrofiação LSF em TFA. .227

Figura 83 - Micrografias das fibras obtidas a partir da eletrofiação de SP, em TFA, em diferentes vazões de solvente. 
Figura 84 - Curvas dTG da (a) LSF de partida e eletrofiada e (b) da SP de partida e eletrofiada (atmosfera de $\mathrm{N}_{2}$, taxa de aquecimento de $20^{\circ} \mathrm{C} \mathrm{min}^{-1}$ ).........................................232 


\section{Lista de Tabelas}

Tabela I - Solventes convencionalmente usados na dissolução da celulose

Tabela 2 - Índice de cristalinidade $\left(I_{c}\right)$ para a celulose de sisal e celulose de sisal mercerizada.

Tabela 3 - Grau de polimerização viscosimétrico médio (GPvis) e massa molar média viscosimétrica (MMvis) da celulose de sisal e celulose de sisal mercerizada

Tabela 4 - Valores obtidos para a-celulose na celulose de sisal e celulose de sisal mercerizada

Tabela 5 - Dados da decomposição térmica da celulose de sisal e celulose de sisal mercerizada obtidos via análises termogravimétricas.

Tabela 6 - Grau de substituição para os diferentes ésteres de celulose de sisal preparados em meio homogêneo (DMAc/LiCl).

Tabela 7 - Dados da decomposição térmica dos ésteres de celulose de sisal obtidos em meio homogêneo via análise termogravimétrica

Tabela 8 - Resultados de grau de substituição para os acetatos e butanoatos de celulose, obtidos em meio heterogêneo.

Tabela 9 - Resultados de grau de substituição para os butanoatos de celulose, obtidos em meio heterogêneo, na segunda etapa do projeto.

Tabela 10 - Filmes e biocompósitos preparados a partir dos ésteres de celulose/celulose de sisal.

Tabela II - Dados da decomposição térmica do filme de celulose de sisal e filmes /biocompósitos preparados a partir dos ésteres de celulose sisal e celulose de sisal.

Tabela 12 - Métodos de análise para caracterização química da superfície de materiais.......I52

Tabela I3 - Filmes/biocompósitos considerados no presente projeto.

Tabela 14 - Comparação da intensidade de contagem de massa do fragmento 99 representação o grupo lateral hexanoato no espectro positivo de ToF-SIMS. As intensidades foram normalizadas pelo número total de contagem.

Tabela 15 - Ângulos de avanço e de recuo para o filme de celulose, filmes de ésteres de celulose e biocompósitos a partir de ésteres de celulose e celulose.

Tabela 16 - Diferentes condições de pré-tratamento (etanol-ácido, $75^{\circ} \mathrm{C}$ ) e dissolução em $\mathrm{NaOH}_{(\mathrm{aq} .)} /$ Uréia e avaliação de formação de microesferas em $\mathrm{HNO}_{3} 2 \mathrm{M}$. 
Tabela 17 - Valores médios de área, índice de circularidade, volume, massa e porosidade total para as microesferas de celulose de sisal e celulose microcristalina preparadas em $\mathrm{NaOH}_{(\text {aq.) }} /$ Uréia e coagulados em diferentes concentrações de $\mathrm{HNO}_{3}$, a $25^{\circ} \mathrm{C}$.

Tabela 18 - Valores médios de área, índice de circularidade, volume, massa e porosidade total para os beads de celulose de sisal e celulose microcristalina preparados em $\mathrm{NaOH}_{(\text {aq.) }} /$ Uréia e coagulados em ácido nítrico $4 \mathrm{M}$ a diferentes temperaturas. .195

Tabela 19 - Processos para a produção ou extração de nanofibras e fibras ultrafinas de celulose altamente purificadas. .209

Tabela 20 - Exemplos de soluções de celulose e derivados de celulose usados na técnica de eletrofiação. 


\section{Lista de Abreviaturas, Siglas e Símbolos}

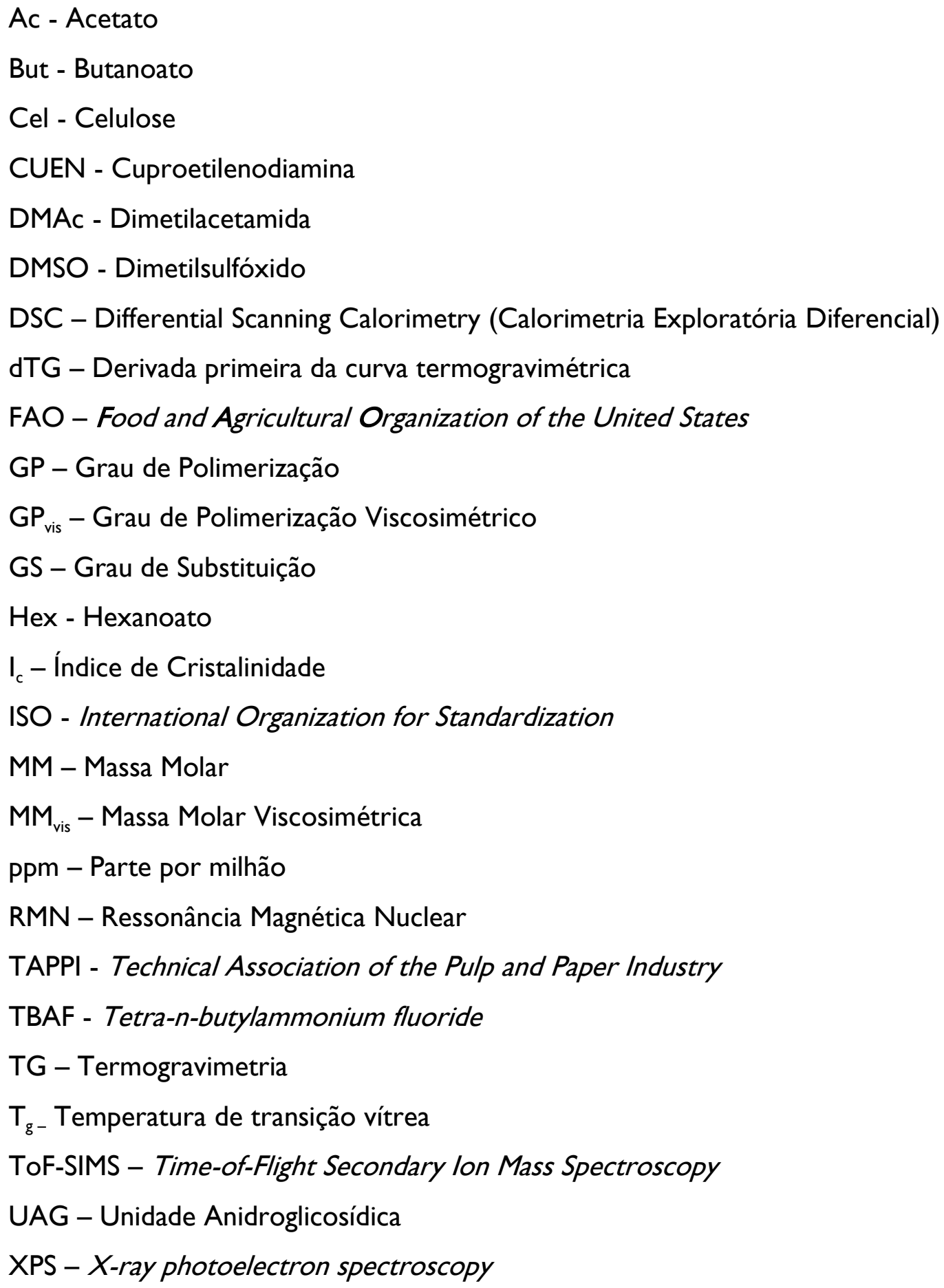





\section{SUMÁRIO}

LISTA DE FIGURAS

LISTA DE TABELAS

LISTA DE ABREVIATURAS, SIGLAS E SÍMBOLOS

CONTEXTUALIZAČ̃̃O DA PROPOSTA

29

REVISÃO BIBLIOGRÁFICA

33

I. BIOMASSA LIGNOCELULÓSICA - FibRAS LIGNOCELULÓSICAS

I.2 PRINCIPAIS COMPONENTES DA FIBRA LIGNOCELULÓSICA

I.2.I Celulose 35

I.2.2 Hemiceluloses (Polioses) 38

I.2.3 LIGNINA 40

I.3 FiBRA LIGNOCELULÓSICA DE SISAL

CAP I. ESTUDOS SOBRE A PREPARAÇÃO DE ÉSTERES DE CELULOSE DE SISAL EM MEIOS HOMOGÊNEO E HETEROGÊNEO

I. INTRODUÇÃO

I.I Celulose com o substrato em reações químicas: Derivatização em Meios HOMOGÊNEO E HETEROGÊNEO

I.2 Mercerização da Celulose 56

I.3 SISTEMA DE SOLVENTE DMAC/LICL 59

I.4 Aplicação dos Ésteres de Celulose 62

2. EXPERIMENTAL 65

2.I Pré-tratamento da Celulose de sisal 66 
2.I.I MERCERIZAÇÃO

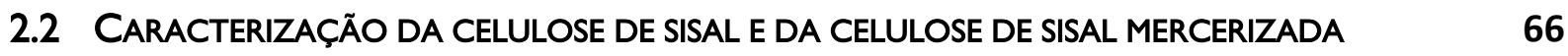

2.2.I AVALIAÇÃO DOS COMPRIMENTOS E TAMANHOS MÉDIOS DAS FIBRAS 66

2.2.2 DeterminaçÃo do teOR DE A-CELULOSE

2.2.3 DOSAGEM DE HEMICELULOSE NA CELULOSE DE SISAL MERCERIZADA 68

2.2.4 DETERMINAÇÃO DO ÍNDICE DE CRISTALINIDADE POR RAIOS X 69

2.2.5 ANÁLISE DO GRAU MÉDIO DE POLIMERIZAÇÃO VISCOSIMÉTRICO E MASSA MOLAR MÉDIA $\begin{array}{ll}\text { VISCOSIMÉTRICA } & 69\end{array}$

2.2.6 ESPECTROMETRIA NA REGIÃO DO INFRAVERMELHO 70

2.2.7 Microscopia Eletrônica de VarRedura 70

2.2.8 ANÁLISE TERMOGRAVIMÉTRICA (TG)

2.3 SÍNTESE DOS ÉSTERES DE CELULOSE

2.3.I MEIO HOMOGÊNEO

2.3.I.I DISSOLUÇÃO EM DMAC/LICL

2.3.1.2 ESTERIFICAÇÃO

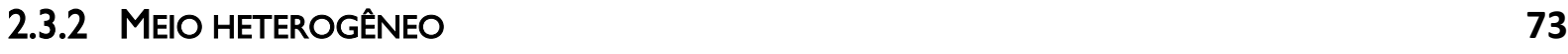

2.3.3 CaracterizaÇão dos Ésteres de CELULOSE

2.3.3.I GRAu de SUBSTItUIÇÃo (RMN 'H)

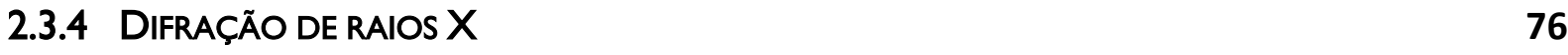

3. RESUltados e Discussão 77

3.I CARACTERIZAÇÃo dA CELULOSE de PARTIDA

3.I.I AVALIAÇÃO DOS COMPRIMENTOS E TAMANHOS MÉDIOS DAS FIBRAS 77

3.I.2 ESPECTROSCOPIA NA REGIÃO DO INFRAVERMELHO 78

3.I.3 DETERMINAÇÃO DO ÍNDICE DE CRISTALINIDADE (DIFRAÇÃO DE RAIOS X) 80

3.I.2 ANÁLISE DO GRAU DE POLIMERIZAÇÃO VISCOSIMÉtRICO E MASSA MOLAR MÉdIA $\begin{array}{ll}\text { VISCOSIMÉTRICA } & 81\end{array}$

3.I.4 DeterminAÇÃo do TEOR DE A-CELULOSE

3.I.5 DOSAGEM DE HEMICELULOSES NA POLPA DE CELULOSE MERCERIZADA 83

3.I.6 Microscopia eletrôNICA de VARREDURA (MEV) 85

3.I.7 ANÁLISE TERMOGRAVIMÉTRICA

3.2 ÉSTERES DE CELULOSE DE SISAL OBTIDOS EM MEIO HOMOGÊNEO 89

3.2.I Grau de Substituição (GS) 
3.2.2 Difração de RAIOS $X$

3.2.3 ANÁLISE TERMOGRAVIMÉTRICA 99

3.3 ÉSTERES DE CELULOSE DE SISAL OBTIDOS EM MEIO HETEROGÊNEO 103

3.2.4 Grau de SubSTITUIÇÃo (GS) 104

4. Breve Resumo e Conclusões Parcials 113

CAP 2. BIOCOMPÓSITOS A PARTIR DE ÉSTERES DE CELULOSE E CELULOSE DE SISAL

$\begin{array}{ll}\text { I. INTRODUÇÃO } & 115\end{array}$

I.I AgregaÇÃo da Celulose no SISTEMA de SOlVENTE DMAC/LICL 115

I.I APLICAÇÃO dOS ÉSTERES DE CELULOSE EM FILMES E (BIO) COMPÓSITOS 118

2. EXPERIMENTAL 121

2.I Preparação dos filmes/biocompósitos a PARTIR de Ésteres de CELULOSE de SISAL E CELULOSE DE SISAL

121

2.2 CARACTERIZAÇÃO dOS FILMES/BIOCOMPÓSITOS A PARTIR DE ÉSTERES DE CELULOSE/CELULOSE DE SISAL

2.2.I ABSORÇÃO DE LÍTIO 123

2.2.2 ANÁLISE ELEMENTAR 123

$\begin{array}{ll}\text { 2.2.3 Difração de RAIOS X } & 124\end{array}$

2.2.4 Microscopia Eletrônica de VarRedura (MEV) 124

2.2.5 ANÁLISE TERMOGRAVIMÉTRICA

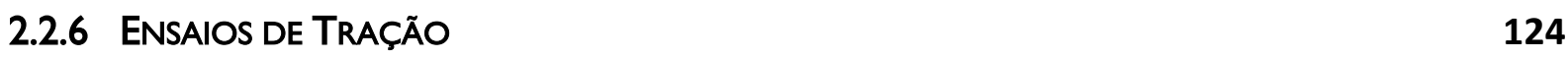

$\begin{array}{ll}\text { 2.2.7 ANÁLISE DINÂMICO-MECÂNICA (DMA) } & 125\end{array}$

3. Resultados e Discussão 127

3.I CARACTERIZAÇÃO dOS FILMES/BIOCOMPÓSITOS A PARTIR DE ÉSTERES DE CELULOSE DE SISAL E $\begin{array}{ll}\text { CELULOSE DE SISAL } & 127\end{array}$

3.I.I ANÁLISE ELEMENTAR E ABSORÇÃo ATÔMICA DE LítIO 127

3.1.2 Microscopia Eletrônica de VarRedura 128

3.I.2.I FILMES A PARTIR DE ACETATO DE CELULOSE DE SISAL 128

3.I.2.2 FILMES A PARTIR DE BUTANOATOS DE CELULOSE DE SISAL 130

3.I.2.3 FILMES A PARTIR DE HEXANOATO DE CELULOSE DE SISAL 133 
3.1.4 ANÁLISE TERMOGRAVIMÉtrICA 138

3.I.5 ANÁlISE DINÂMICO-MECÂNICA 139

3.I.6 ENSAIOS DE TRAÇÃO $\quad 145$

4. BreVe Sumário e Conclusões Parcials 149

CAP 3. FILMES DE ÉSTERES DE CELULOSE E CELULOSE DE SISAL: ESTUDOS DE SUPERFÍCIE UTILIZANDO XPS, TOF-SIMS E ÂNGULO DE CONTATO 151

$\begin{array}{ll}\text { I. INTRODUÇÃO } & 151\end{array}$

I.I TÉCNICAS DE MICROSCOPIA

I.2 Microscopia Eletrônica de VARRedura por EMissão de CaMPO 152

I.3 XPS (X-RAY PHOTOELECTRON SPECTROSCOPY) 154

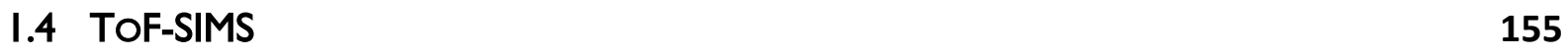

I.5 XPS E TOF-SIMS COMO TÉCNICAS COMPLEMENTARES 156

2. EXPERIMENTAL 159

$\begin{array}{ll}2.1 \text { XPS } & 160\end{array}$

$\begin{array}{lll}2.2 & \text { TOF-SIMS } & 161\end{array}$

2.3 ÂNGULO de CONTATO 161

3. Resultados e Discussão 162

$\begin{array}{lll}3.1 & X P S & 162\end{array}$

$\begin{array}{lll}3.2 & \text { TOF-SIMS } & 167\end{array}$

3.3 ÂNGULO de CONTATO 170

4. BreVe Sumário e Conclusões Parcials 177

CAP 4. MICROESFERAS DE CELULOSE DE SISAL

$\begin{array}{ll}\text { I. INTRODUÇÃO } & 179\end{array}$

$\begin{array}{lll}\text { I.I Microesferas de Celulose } & 179\end{array}$

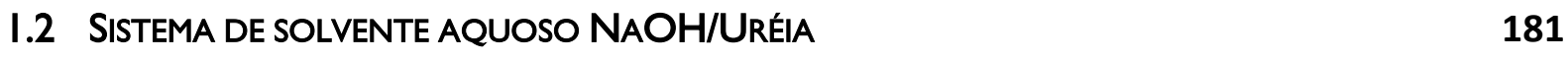

I.3 Pré-tratamento na biomassa Celulósica 184

I. TRATAMENTO ÁCIDO 185 
$\begin{array}{ll}\text { 2. EXPERIMENTAL } & 187\end{array}$

$\begin{array}{ll}\text { 2.I MATERIAIS } & 187\end{array}$

2.2 Pré-tratamento da Celulose de sisal 187

2.3 Pré-Estudo da dissolução da Celulose de sisal no sistema aQuoso baseado em NAOH/URÉIA

2.4 Preparação das microesferas de Celulose a partir da dissolução em NaOH/Uréla 188

2.5 CARACTERIZAÇÃO DAS MICROESFERAS

2.5.I FE-SEM

2.5.2 DETERMINAÇÃO DA ÁREA, VOLUME, ÍNDICE DE CIRCULARIDADE E POROSIDADE TOTAL DAS MICROESFERAS DE CELULOSE

2.5.3 AVALIAÇÃO DA RESISTÊNCIA DAS MICROESFERAS DE CELULOSE APÓS APLICAÇÃO DE FORÇA CENTRÍFUGA EM DIFERENTES CONDIÇÕES

3. RESULTADOS E DISCUSSÃO

3.I ESTUdO DA DISSOLUÇÃo DA CELULOSE DE SISAL NO SISTEMA AQUOSO NAOH/URÉIA 191

3.2 Preparação das microesferas de celulose a partir da dissolução em NaOH/Uréia 193

3.3 DETERMINAÇÃO DA ÁREA, ÍNDICE DE CIRCULARIDADE, FORMA, MASSA E POROSIDADE TOTAL DAS MICROESFERAS

3.4 FE-SEM 196

3.5 AVALIAÇÃO DA RESISTÊNCIA DAS MICROESFERAS APÓS APLICAÇÃO DE FORÇA CENTRÍFUGA 200

4. Breve Sumário e Conclusões Parciais 203

CAP 5. ELETROFIAÇÃO DA FIBRA LIGNOCELULÓSICA DE SISAL E SEUS DERIVADOS

$\begin{array}{ll}\text { I. INTRODUÇÃO } & 205\end{array}$

$\begin{array}{lll}\text { I.I DEFINIÇÃO DE NANOFIBRAS } & 205\end{array}$

$\begin{array}{lll}\text { I.2 Fibras ULTRAFINAS E NANOFIBRAS } & 208\end{array}$

I.3 EletrofiaçÃo (ELECTROSPINNING) 210

I.3.I FUNDAMENTOS DA TÉCNICA DE ELETROFIAÇÃO 212

I.3.2 EletrofiaçÃo APLICADA A BIOMASSA CELULÓSICA 215 
$\begin{array}{lr}\text { 2. EXPERIMENTAL } & 219\end{array}$

2.I MATERIAIS 219

2.2 DisSOlUÇÃO DOS MATERIAIS DE PARTIDA 219

2.3 Processo de EletrofiaçÃo 220

2.4 CARACTERIZAÇÃO DOS MATERIAIS $\quad 220$

2.4.I FTIR-ATR 220

2.4.2 Microscopia Eletrônica de VarRedura 221

2.4.3 ANÁLISE TERMOGRAVIMÉTRICA

3. RESULTADOS E DISCUSSÃO 223

$\begin{array}{llr}3 . I & \text { FTIR-ATR } & 223\end{array}$

3.2 Microscopia Eletrônica de Varredura (MEV) 226

3.3 ANÁLISE TERMOGRAVIMÉtRICA 231

4. Breve Sumário e Conclusões parcials 233

CONCLUSÕES GERAIS $\quad 235$

REFERÊNCIAS BIBLIOGRÁFICAS 


\section{CONTEXTUALIZAÇÃO DA PROPOSTA}

a última década, a obtenção do bioetanol, designação adotada para
diferenciar do etanol obtido por rotas tradicionais, vem ganhando um grande espaço na discussão sobre a utilização da biomassa (KIM; DALE, 2004; HAHN-HÄGERDAL et al., 2006; VAN EIJCK; BATIDZIRAI; FAAIJ, 20I4). Neste caso, a biomassa corresponde aos lignocelulósicos e ao seu principal componente, a celulose. Embora atualmente o bioetanol desperte um forte apelo nesta área, é importante destacar que, a partir da celulose e lignocelulósicos, uma imensa diversidade de aplicações pode ser encontrada. Assim, as aplicações de celulose e lignocelulósicos na área de biocombustíveis ampliam também o uso destes materiais em outras áreas, devido ao aumento da produção dos mesmos (LYND et al., 2005; ALBUQUERQUE et al., 20I4; THAKUR et al., 20I4).

Considerando a área disponível para cultivo no país e a relevância de desenvolvimento de pesquisas relacionadas à utilização de biomassa, assim como a importância da formação de recurso humano na área, é imperativo que esforços sejam concentrados no sentido de valorizar a matéria-prima proveniente da agricultura. Neste sentido, o presente trabalho tem como objetivo central a valorização da fibra lignocelulósica, e a celulose extraída desta, como matérias-primas de partida na preparação de novos materiais.

O presente trabalho se insere dentro de um amplo projeto, o qual tem como objetivo a valorização de fibras naturais, no caso as fibras lignocelulósicas e também de seus componentes isolados, no caso, a celulose e lignina. Preferencialmente, fibras lignocelulósicas obtidas a partir de plantas de curto ciclo de crescimento e abundantes no país (como sisal, curauá e bagaço de cana-de-açúcar) têm sido consideradas. Adicionalmente, celulose microcristalina e obtida do algodão (linter) também têm sido alvos de investigações. $O$ projeto supracitado está subdividido em diferentes linhas de pesquisa, podendo-se destacar entre elas:

(I) Desenvolvimento de materiais compósitos a partir do uso de diferentes matrizes e fibras lignocelulósicas como agentes de reforço. Alguns exemplos recentes: Matrizes termoplásticas, tais como matrizes de politereftalato de etileno reciclado 
reforçados com fibras de sisal (DE OLIVEIRA SANTOS et al., 20I4); biopolietileno de alta densidade reforçados por fibras de curauá (CASTRO et al., 2013; CASTRO, 20I4). Matrizes poliuretânicas, preparadas a partir de lignossulfonato de sódio e óleo de mamona, reforçados com diferentes fibras lignocelulósicas (RAMIRES; DE OLIVEIRA; FROLLINI, 20I3). Matrizes taninofenólicas reforçadas por fibras de sisal (RAMIRES; FROLLINI, 20I2).

(2) Sacarificação do material lignocelulósico, como a polpa de sisal, visando à produção de açúcares, o que corresponde à primeira etapa do processo de produção do bioetanol (DE PAULA et al., 20I2; LACERDA; ZAMBON; FROLLINI, 20I3; KASCHUK, 20I4).

(3) Estudos da funcionalização da celulose em meios heterogêneo (PERES DE PAULA; LACERDA; FROLLINI, 2008) e homogêneo, neste último utilizando o sistema de solvente DMAc/LiCl (ASS; CIACCO; FROLLINI, 2006; ALMEIDA et al., 20l3). Estudos acerca dos aspectos físico-químicos envolvidos nas reações, assim como os aspectos envolvidos na agregação da celulose e de seus derivados no sistema de solvente DMAc/LiCl (MORGADO; MARTINS; et al., 20II; RAMOS, L. et al., 20II).

(4) Preparação e caracterização de filmes e biocompósitos a partir de ésteres de celulose obtidos em meio homogêneo e celulose como fase de reforço. Alguns exemplos recentes: Celulose de linter (MORGADO et al., 20I3) e celulose de sisal (ALMEIDA et al., 20I3; RODRIGUES et al., 20I4) como reforço em biocompósitos preparados a partir de seus ésteres derivados.

A celulose é um material de grande interesse acadêmico e industrial, por se tratar de um recurso natural não fóssil, renovável, biodegradável e ser o polímero mais abundante na natureza. Ademais, do ponto de vista químico, a estrutura da celulose combinada com propriedades como hidrofilicidade, biocompatibilidade, estereorregularidade e polifuncionalidade (grupos hidroxila reativos) fazem desse polissacarídeo uma excelente macromolécula de partida na preparação de novos materiais (HEINZE; LIEBERT, 200I; KLEMM et al., 2005; QIU; NETRAVALI, 20I4). No entanto, para que a indústria de celulose possa competir com aquela que usa matéria-prima de natureza fóssil, vários problemas devem ser sanados, desde aqueles relacionados com aspectos econômicos até os que envolvam pesquisa fundamental. 
A principal fonte de celulose é a madeira, a qual corresponde a um material de lenta regeneração, considerando o número de anos que são necessários para que uma árvore possa ser utilizada para produzir celulose. A utilização de celulose obtida de fontes de crescimento rápido, como a fibra de sisal utilizada no presente trabalho, vem em direção a favorecer a competitividade econômica (SIBANI et al., 20I2; DE OLIVEIRA SANTOS et al., 20I4).

A celulose (principalmente obtida de bagaço de cana-de-açúcar, sisal e linter, além da microcristalina) vem sendo utilizada em estudos que visam principalmente à funcionalização desta macromolécula, com ênfase para a preparação de ésteres em meios homogêneo e heterogêneo (REGIANI et al., I999; ASS; CIACCO; FROLLINI, 2006; PERES DE PAULA; LACERDA; FROLLINI, 2008; RAMOS, L. et al., 20II; MORGADO et al., 20I3). Compreende-se que a celulose de sisal, em decorrência de sua enorme disponibilidade no Brasil, curto ciclo de crescimento e alto teor de celulose, deve ser objeto de detalhado estudo no que diz respeito à sua derivatização e aplicação em novos materiais. Embora a derivatização em meio heterogêneo seja, hoje, a mais amplamente usada na indústria, a derivatização em meio homogêneo, na qual ocorre primeiramente a dissolução da celulose e depois a derivatização, visa à produção de derivados celulósicos com características melhor definidas, uma vez que a reação ocorre de forma mais uniforme ao longo da cadeia. Ademais, o meio homogêneo permite sínteses com maior controle, no que diz respeito ao controle do grau de grau de substituição do produto final.

Como observado na breve descrição dos projetos, o conhecimento acumulado nesta área levou ao interesse em desenvolver estudos relacionados à utilização destes ésteres na preparação de filmes baseados em ésteres de celulose e reforçados com celulose, visando materiais com melhores propriedades mecânicas. $\bigcirc$ melhoramento destas propriedades age no sentido de ampliar a aplicação destes materiais, como por exemplo, na área de embalagens, na qual estes materiais estarão corriqueiramente sujeitos a solicitações mecânicas.

Neste contexto, parte deste trabalho (Capítulos I e 2) corresponde a uma continuação, acompanhada de ampliação, de estudos anteriores em que acetatos de celulose, de diferentes graus de substituição (GS), foram preparados e utilizados como matrizes na preparação de filmes reforçados por celulose (ALMEIDA et al., 20I3; MORGADO et al., 2013). No presente estudo, reporta-se a preparação e caracterização de ésteres de celulose 
de sisal de cadeias de diferentes tamanhos (acetatos, butanoatos e hexanoatos) e diferentes GS. Meios homogêneo (DMAc/LiCl) e heterogêneos foram considerados, a fim de se avaliar os diferentes rendimentos obtidos para os diferentes tamanhos de cadeia. Os ésteres preparados em meio homogêneo (DMAc/LiCl) foram posteriormente utilizados na preparação de filmes e biocompósitos (Capítulo 2), estes últimos preparados a partir de soluções mistas constituídas por ésteres de celulose e celulose, visando a obtenção de materiais com uma diversidade de propriedades finais e propriedades mecânicas superiores.

Em uma segunda etapa do trabalho (descrita nos Capítulos 3 e 4 deste texto), a qual foi realizada em colaboração com a Åbo Akademi University (Turku, Finlândia) e sob cosupervisão do Prof. Dr. Pedro Fardim, técnicas avançadas de microscopia (como XPS e ToFSIMS) foram consideradas no estudo das superfícies dos filmes/biocompósitos preparados a partir dos ésteres de celulose e celulose de sisal (Capítulo 3). Ainda, nesta mesma colaboração, considerou-se a polpa de sisal como material de partida para a preparação de outra classe de materiais, conhecida como beads (microesferas) (Capítulo 4).

$\mathrm{Na}$ última parte deste trabalho, Capítulo 5, relata-se a utilização de uma técnica recentemente introduzida no Grupo de Pesquisa no qual este trabalho foi desenvolvido, conhecida como eletrofiação (electrospinning). Esta técnica permitiu que, a partir da fibra lignocelulósica de sisal ou seu componente principal, a celulose, fibras na escala nano (fibras<100) e micro $(100<$ fibras < 1000$)$ fossem obtidas a partir de soluções desses materiais. Destaca-se que a obtenção de fibras nesta escala, a partir de uma fibra lignocelulósica não previamente tratada, tem caráter inédito, até onde atinja o nosso conhecimento. Esses resultados abriram novos caminhos para que esse método começasse a ser utilizado em outros trabalhos de pesquisa do Grupo, no qual mantas de polímeros termoplásticos têm sido preparadas via técnica de eletrofiação, com reforço da fibra lignocelulósica. 


\section{REVISÃO BIBLIOGRÁFICA}

Como já mencionado anteriormente, a fim de dinamizar o processo de leitura, o presente trabalho foi dividido em capítulos. Cada qual trata de aspectos distintos no uso da fibra lignocelulósica ou celulose de sisal e seus derivados ésteres na preparação de diferentes materiais, tais como filmes, biocompósitos, fibras ultrafinas, nanofibras e microesferas. Assim, a cada capítulo, optou-se por agregar uma breve introdução com a função de abordar pontos-chaves, os quais discorrem sobre a teoria, conceitos e técnicas envolvidos na elaboração experimental e discussão dos resultados. Todavia, uma concisa revisão bibliográfica é apresentada nas seções seguintes, as quais se referem a conceitos gerais e fundamentais acerca da biomassa lignocelulósica, a qual foi escolhida como matéria-prima de partida no presente estudo.

\section{Biomassa lignocelulósica - Fibras lignocelulósicas}

biomassa lignocelulósica é a matéria-prima mais abundante do mundo, sendo
originada principalmente de atividades agrícolas. Esse tipo de biomassa pode ser categorizado em três grupos distintos: biomassa virgem, resíduos da biomassa e cultivos geradores de energia (energy crops).

I. Biomassa virgem: inclui todas as plantas de ocorrência natural, tais como as árvores, matas, gramíneas, sisal.

2. Resíduos da biomassa: incluem todos os subprodutos de baixo valor em diversos setores industriais, tais como o setor agrícola (palha de milho, bagaço de cana-deaçúcar), silvicultura (serraria, descartes de fábricas de papel).

3. Cultivos geradores de energia: incluem as culturas com alto rendimento provenientes da biomassa lignocelulósica, produzidas principalmente como matéria-prima para produção de biocombustíveis de segunda geração. Incluem: madeira, switch grass (Panicum virgatum), Miscanthus sinensis. 
Os principais componentes da biomassa lignocelulósica são a celulose, hemiceluloses (polioses) e lignina, sendo que pequenas proporções de proteínas, lipídeos (gorduras, ceras, óleo) e cinzas também podem estar presentes. A proporção relativa dos três principais componentes é estritamente correlacionada com cada espécie e características de plantio, tais como solo, umidade e clima (REDDY; YANG, 2005). A celulose é o componente mais abundante nas paredes celulares das plantas, seguido das hemiceluloses e por fim, lignina. Uma discussão mais detalhada acerca de cada componente é apresentada ao longo das próximas seções.

A estrutura de um material lignocelulósico é representada na Figura I, sendo possível visualizar a fibra lignocelulósica variando da escala macro até nano, assim como os seus principais componentes e distribuição dos mesmos.

Figura I - Representação da estrutura de uma fibra lignocelulósica e seus principais componentes.

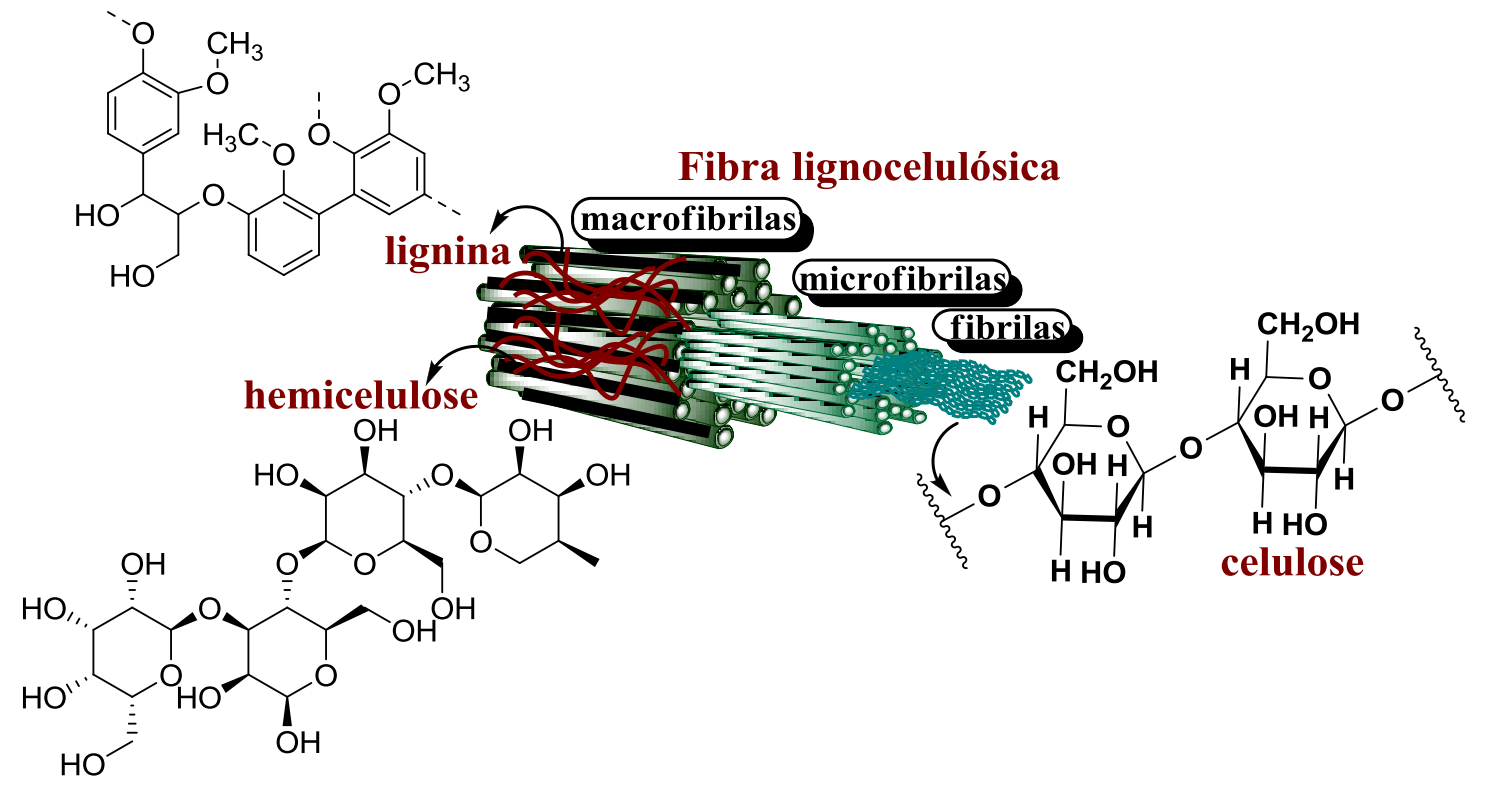

As fibras vegetais podem ser extraídas de diferentes partes da planta, tais como caule (bambu, malva, juta, bagaço de cana-de-açúcar); folha (sisal, curauá, bananeira), fruto (algodão, coco verde, coco maduro); tronco (madeira), entre outros (RAZERA, 2006). Assim, as fibras lignocelulósicas diferem consideravelmente entre si, entretanto com uma característica comum intrínseca, que é a presença dos três componentes supracitados. 


\section{I.2 Principais componentes da fibra lignocelulósica}

\section{I.2.I Celulose}

A celulose, que é considerada o polímero mais abundante no mundo, vem servindo à humanidade a milhares de anos, como um material indispensável e com uma vasta gama de empregabilidade, seja na forma de têxtil (e.g., algodão e linho) ou de construção (e.g., madeira). Este polissacarídeo, que é um dos principais constituintes da parede celular da maioria das plantas, foi descoberto em 1838 pelo químico francês Anselme Payen, o qual foi responsável por isolar a celulose e determinar sua fórmula química. Posteriormente, a celulose foi usada para produzir o primeiro polímero termoplástico, a celulóide, pela Hyatt Manufacturing Company, em 1870. A produção de raiom, preparada a partir de celulose regenerada, começou em meados de 1890 , enquanto o celofane teve a sua origem já em 1912 (ZUGENMAIER, 2008).

Antes de 1920, o único conhecimento a respeito da estrutura química da celulose era a presença de glicose em sua constituição. Naquela época, três grupos hidroxilas em cada unidade de glicose eram detectáveis por derivatização e degradação (ZUGENMAIER, 2008). Em 192I, KARRER; WIDMER (192I) propuseram novos conceitos a respeito da constituição de macromoléculas como o amido e a celulose, que levou a uma década de controvérsias. KARRER; WIDMER (192I) determinaram que o amido e a celulose seriam formados por anidridos de maltose e celobiose, respectivamente, como resultado de experimento de degradação. Juntamente com Staundiger, cientista responsável por propor que um grande número de pequenas e básicas moléculas são covalentemente ligadas para formar macromoléculas, Karrer quebrou paradigmas presentes até aquele momento a respeito da celulose enquanto uma macromolécula polimérica (ZUGENMAIER, 2008).

A celulose (Figura 2) é um polímero descrito como uma cadeia linear de moléculas de glicoses aneladas, a qual possui uma conformação do tipo fita-plana (MOON et al., 20I I). A unidade de repetição (UAG, Unidade Anidroglicosídica) é constituída de dois anéis de anidroglicose $\left[\left(\mathrm{C}_{6} \mathrm{H}_{12} \mathrm{O}_{6}\right)_{n}\right.$, sendo que $n$ depende da fonte de obtenção de celulose]. Estes anéis de anidroglicose são unidos por meio de uma ligação covalente de um átomo de 
oxigênio entre o carbono $\mathrm{Cl}$ de um anel de glicose e o carbono $\mathrm{C} 4$ de um anel adjacente

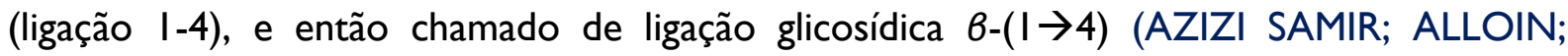
DUFRESNE, 2005).

Figura 2 - Estrutura da celulose.

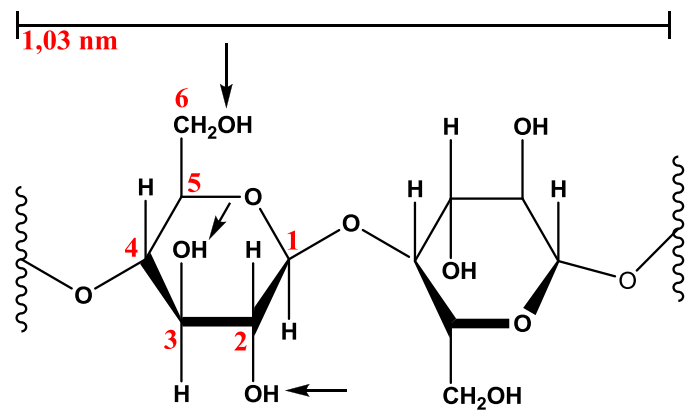

A estabilização das ligações, por meio de ligação hidrogênio intramolecular entre grupos hidroxilas (indicados pelos tracejados em vermelho, Figura 3) e oxigênios de anéis adjacentes, resulta em uma configuração linear da cadeia de celulose. A rede de ligações intra e intermoleculares de hidrogênio faz da celulose um polímero relativamente estável (Figura 3), conferindo uma alta rigidez axial às fibrilas de celulose (TASHIRO; KOBAYASHI, 1991).

$\mathrm{Na}$ celulose, os grupos hidroxílicos, em $\mathrm{C} 2$ e $\mathrm{C} 3$, e o presente em $-\mathrm{CH}_{2} \mathrm{OH}$ no carbono C5 encontram-se no plano equatorial do anel, apontando radialmente para fora, assim como acontece nas ligações glicosídicas entre $\mathrm{Cl}$ e $\mathrm{C4}$; somente os átomos de hidrogênio situam-se no eixo axial (apontando alternativamente para cima ou para baixo do plano do anel). Estas configurações são de extrema importância na estrutura da celulose. Os grupos mais volumosos (grupos hidroxílicos e $-\mathrm{CH}_{2} \mathrm{OH}$ ) tem mais espaço e estão mais afastados quando situados no plano equatorial do que estariam no caso de ocupar posições axiais. A distribuição equatorial destes grupos volumosos pode ser alcançada sem a necessidade de "tensionar" ligações na molécula. Além do mais, esta configuração permite duas ligações hidrogênio entre resíduos da mesma cadeia polimérica: no caso, entre o grupo hidroxílico presente em C3 e O5' presente no anel do resíduo de glicose adjacente; e entre o oxigênio hidroxílico presente em C6 e hidroxila presente em C2 no resíduo adjacente (WALKER, 2006).

A rotação de $180^{\circ}$ entre unidades adjacentes na mesma cadeia polimérica coloca os átomos de carbono de $\mathrm{C} 2$ e C6 no mesmo lado da cadeia de polímero. Da mesma forma, as 
unidades de celobiose adjacentes estão inclinadas em um ângulo sutil (um ziguezague moderado), o que traz os dois grupos hidroxila suficientemente próximos para realizar uma ligação hidrogênio intramolecular efetiva, o que contribui para enrijecer o polímero. A grande tensão e resistência à tração das moléculas de celulose são devidas à ligação covalente e os alinhamentos axiais das microfibrilas como um todo (WALKER, 2006).

Figura 3 - Representação das ligações hidrogênio intermoleculares e intramoleculares na estrutura cristalina da celulose.

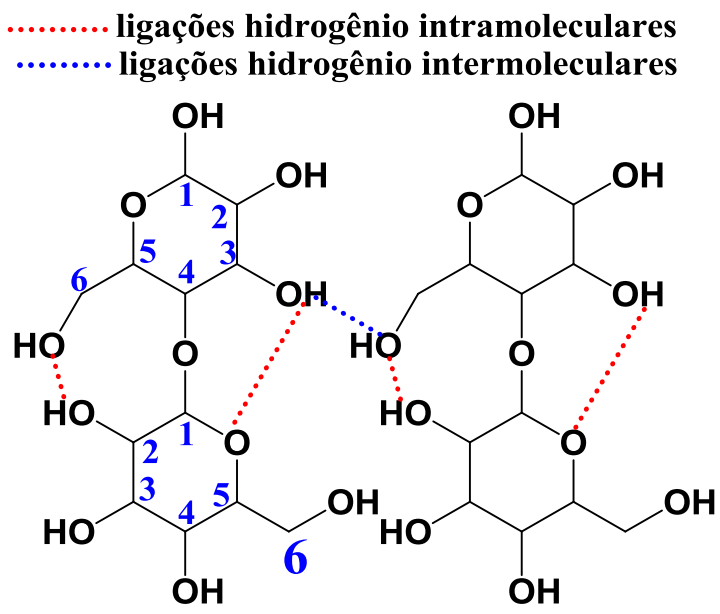

Dentre as possíveis ligações hidrogênio intermoleculares, aquela entre $\mathrm{OH}(6)$ e $\mathrm{O}$ (3) de outra cadeia pode ser considerada como a mais importante para a celulose nativa, de um ponto de vista químico. No estado cristalino, as cadeias celulósicas se empacotam em camadas, com todas as ligações hidrogênio situando-se no plano destas camadas. Estas cadeias paralelas realizam ligações hidrogênio com as cadeias poliméricas vizinhas por meio da ligação entre $\mathrm{OH}$ (6) de uma cadeia e O (3) de uma cadeia vizinha (WALKER, 2006). As ligações hidrogênio intermoleculares são um fator importante na coesão inter-cadeias. Esta coesão é favorecida pela alta regularidade espacial dos sítios onde ocorrem as ligações hidrogênio, e pelo envolvimento dos três grupos hidroxilas na rede de ligações hidrogênio (KLEMM et al., 2004).

A estrutura química da celulose e os arranjos formados pela sua estrutura supramolecular governam diretamente a reatividade desse polímero (KLEMM et al., 2004). Os grupos hidroxilas presentes nesse polímero (Figura 2, indicados por setas nas posições $\mathbf{2}$, 3 e 6) podem participar de reações químicas, seja atuando como nucleófilos em reações de substituição nucleofilica (EYLEY; THIELEMANS, 20I4; SCHMIDT; LIEBERT; HEINZE, 20I4), adição à carbonila (RAMOS, L. et al., 20I I; RATANAKAMNUAN; MANOROM; INTHASAI, 
20I3; RODRIGUES et al., 20I4), ou mesmo em reações de oxidação (ZHANG, K. et al., 20I2; ISOBE, N. et al., 20I3; TAUBNER et al., 20I3). A regularidade e a extensão com que ocorrem as ligações hidrogênio entre os grupos hidroxila de cadeias adjacentes de celulose resultam em um material cristalino fortemente empacotado. Como consequência, a estrutura supramolecular da celulose é responsável por algumas outras propriedades, tais como "não fusão" a altas temperaturas (ocorrendo decomposição prévia, devido à alta energia térmica que seria necessária) e insolubilidade em água, devido à fração de grupos hidroxila disponível para interagir com a água ser limitada (ASS; FROLLINI; HEINZE, 2004).

A ordem de reatividade dos grupos hidroxila da celulose mais citada na literatura é: $\mathrm{OH}$ (6) >> OH (2) > OH (3) (KLEMM et al., 2004; RAMOS, L. et al., 20I I). Considerando que $\mathrm{OH}$ (6) está ligado a um carbono primário e sabendo que $\mathrm{OH}$ (3) participa de ligação hidrogênio intramolecular, a qual é mais difícil de ser rompida (Figura 3), esta ordem parece ser lógica, embora se encontre na literatura descrições de resultados que podem diferir desta ordem de reatividade (DAWSEY; MCCORMICK, 1990).

\section{I.2.2 Hemiceluloses (Polioses)}

As hemiceluloses são polissacarídeos presentes nas paredes celulares das plantas e correspondem ao segundo componente majoritário das fibras lignocelulósicas. As hemiceluloses contribuem para a rigidez da parede celular (juntamente com a celulose e lignina, seção I.2.3) e incluem xilanas, unidades de 6 -I,4-D-xilose ligadas, mananas, unidades de 6 -I,4-D-manose ligadas, arabinanas, unidades de $\alpha$-I,5-L-arabinose ligadas e galactanas, unidades de 6-I,3-D-galactose ligadas (SPIRIDON; POPA, 2008). A distribuição das diferentes unidades de açúcares é heterogênea e depende do tipo e origem da planta.

Nos materiais lignocelulósicos, tem-se a xilana como o principal constituinte da massa hemicelulósica, com o teor variando de 25-35\% (EBRINGEROVÁ; HEINZE, 2000). De fato, em plantas anuais, como a fibra de sisal usada neste trabalho, as principais hemiceluloses são representadas por xilanas. Estas possuem uma estrutura que consiste em um esqueleto linear de resíduos de $\beta$-I,4-D-xilanopiranose ligados, os quais podem conter ramificações contendo grupos acetila, arabinosila e glicoronosila, a depender da fonte botânica 
(SPIRIDON; POPA, 2008). MEGIATTO JR et al. (2007) reportaram um conteúdo de cerca de $68 \%$ de xilanas constituindo a massa de hemicelulose seca da fibra lignocelulósica de sisal (Figura 4).

Figura 4 - Composição de açúcares presentes na massa de hemicelulose seca da fibra lignocelulósica de sisal (MEGIATTO JR et al., 2007).

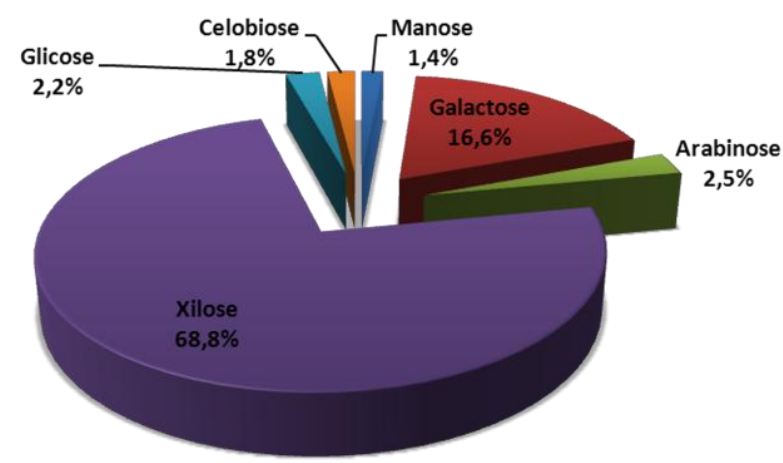

$\mathrm{Na}$ Figura 5, as estruturas químicas das unidades de açúcares presentes nas hemiceluloses são apresentadas. 
Figura 5 - Estruturas químicas das unidades de açúcares presentes nas hemiceluloses.

\section{Hexoses}

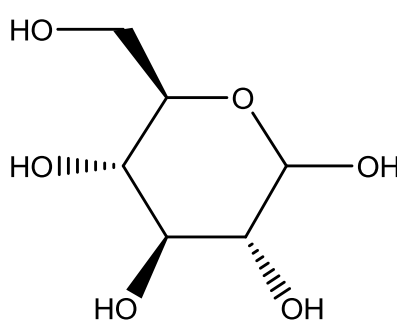

$\beta$-D-glicopiranose<smiles>OC[C@H]1O[C@H](O)[C@H](O)[C@H](O)[C@H]1O</smiles>

$\beta$-D-manopiranose

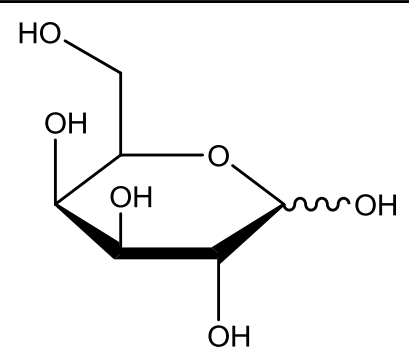

$\alpha$-D-galactopiranose

\section{Pentoses}<smiles>O[C@@H]1CO[C@@H](O)[C@H](O)[C@@H]1O</smiles>

$\beta$-D-xilopiranose<smiles>O[C@@H]1CO[C@@H](O)[C@H](O)[C@@H]1O</smiles>

$\alpha$-L-arabinopiranose<smiles>OC[C@H]1O[C@H](O)[C@@H](O)C[C@H]1O</smiles>

$\alpha$-L-arabinofuranose

\section{Ácidos hexurônicos}<smiles>O=C(O)[C@H]1O[C@@H](O)[C@H](O)[C@H](O)[C@H]1O</smiles>

ácido- $\beta$-D-glicourônico<smiles>C[C@H]1[C@@H](C(=O)O)O[C@H](O)[C@@H](O)[C@@H]1O</smiles>

ácido $\alpha$-D-4-O-metil-glicourônico<smiles>C[C@@H]1[C@@H](C(=O)O)O[C@@H](O)[C@H](O)[C@@H]1O</smiles>

ácido $\alpha$-D-galactourônico

\section{I.2.3 Lignina}

Após a celulose, a lignina é considerada a segunda matéria-prima natural mais abundante do mundo e a primeira mais abundante na classe de macromoléculas fenólicas. $\mathrm{O}$ total de lignina no mundo é estimado por representar aproximadamente $30 \%$ do carbono 
orgânico em toda a biosfera. A presença de lignina nas paredes celulares dos vegetais reflete a sua função na manutenção de uma matriz rígida em torno das fibras de celulose/hemiceluloses, apresentando funções de coesão e barreira frente à umidade (BURTON; GIDLEY; FINCHER, 20I0).

$\mathrm{Na}$ biomassa vegetal, as cadeias de celulose estão intimamente associadas às hemiceluloses na formação de estruturas lineares de alta resistência, chamadas microfibrilas (Figura I). As fibras presentes na parede celular das plantas são constituídas pelo empilhamento de camadas destas microfibrilas. As cadeias celulósicas presentes nas regiões cristalinas e não cristalinas são rodeadas por hemiceluloses, as quais se associam e emaranham com as macromoléculas de lignina (Figura I).

A lignina, enquanto macromolécula, não pode ser facilmente descrita por uma simples combinação de uma ou poucas unidades monoméricas, ou pela combinação de poucas ligações, como acontece nos casos da celulose e hemiceluloses. A estrutura da lignina, desde meados dos anos 70, é matéria de muitas investigações e modelos (FREUDENBERG et al., 1965; FREUDENBERG; NIMZ, 1966; NIMZ, 1974). Naturalmente, as ligninas são sintetizadas por reações combinadas de acoplamento fenólico, as quais são induzidas por radicais livres enzimaticamente gerados. Por meio deste mecanismo, três lignóis (Figura 6) agem como monômeros em reações com o radical em crescimento, caracterizando uma polimerização em cadeia clássica.

Figura 6 - Alcoóis precursores nas reações de formação da lignina.<smiles>COc1cc(/C=C/CO)ccc1O</smiles>

Assim, devido ao grande número de possíveis sequências durante o curso da reação, uma grande diversidade de macromoléculas de lignina pode ser formada, tornando improvável que duas macromoléculas de lignina sejam perfeitamente idênticas. Para 
exemplificar, temos o conceito estrutural de lignina de faia proposto por Nimz em 1974 (Figura 7).

Figura 7 - Conceito estrutural da lignina de faia de acordo com NIMZ (I 974).

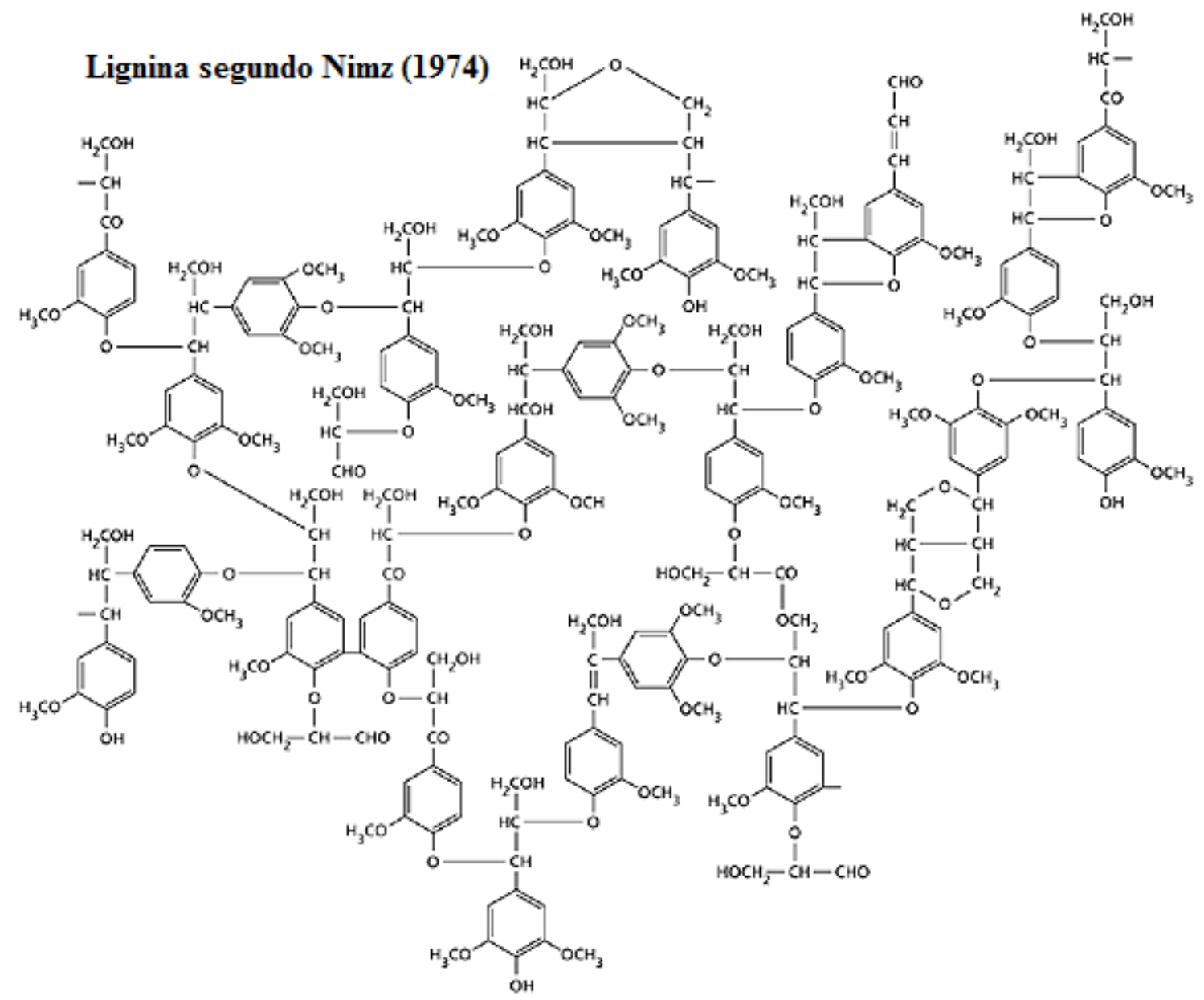

No presente estudo, escolheu-se a fibra lignocelulósica de sisal, e a celulose extraída a partir dela, como matérias-primas de partida para a síntese de ésteres de celulose de sisal e para a preparação de diferentes classes de materiais. A seção a seguir abordará os principais aspectos relacionados à escolha dessa fonte lignocelulósica.

\section{I.3 Fibra lignocelulósica de sisal}

O sisal (Figura 8) é uma planta do gênero Agave e da família das Agavaceae. A espécie cultivada e mais utilizada no Brasil, para fins comerciais da fibra, é a Agave sisalana. 
Atualmente, os principais produtores de sisal são o Brasil, Tanzânia, México, Quênia, Colômbia, Madagascar, Cuba e Haiti, sendo o Brasil isoladamente o principal produtor de sisal, com uma área de cultivo em torno de 280 mil hectares (FAO, 20I3). Devido à facilidade de cultivo e curto ciclo de crescimento (em torno de nove meses), a fibra de sisal é uma das fibras naturais mais amplamente utilizadas e com aplicações diversificadas.

Figura 8 - Foto de uma plantação de sisal (Fonte: http://3.bp.blogspot.com/-9p3 I BgueGBM).

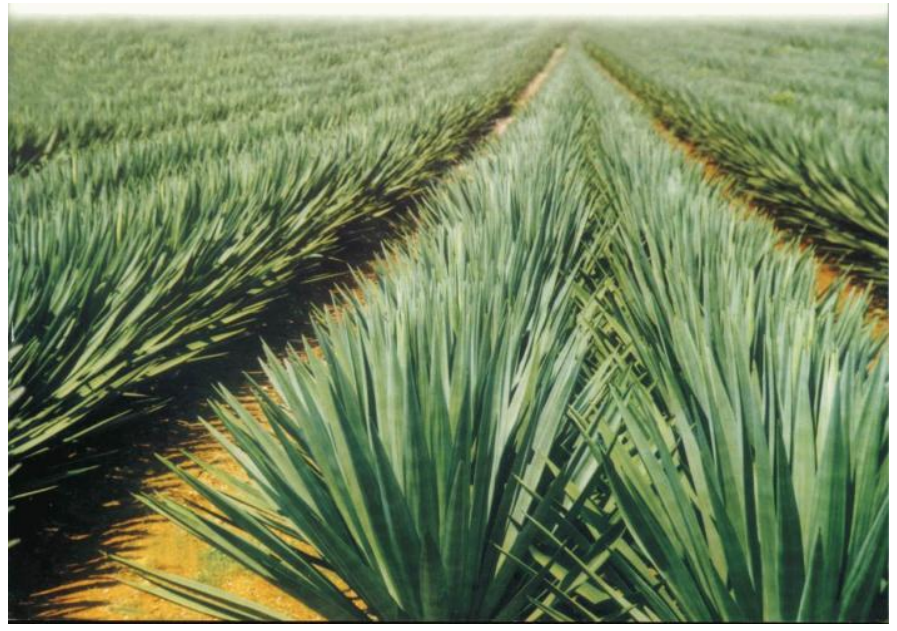

Dentro do conjunto das fibras duras (fibras fiáveis, de origem vegetal, que apresentam elevada resiliência e resistência mecânica), o sisal tem lugar de destaque, representando aproximadamente $70 \%$ da produção comercial de todas as fibras desse tipo. Considerando toda a cadeia de serviços, isto é, desde a manutenção de lavouras e colheita até industrialização e confecção de artesanato, a fibra de sisal (industrializada ou beneficiada) é responsável por gerar cerca de $\bigcup \$ 80.000 .000$ em divisas para ○ Brasil. Ademais, deve-se à supracitada cadeia de serviços mais de meio milhão de empregos, os quais são gerados em virtude da manutenção do sistema (DE OLIVEIRA SANTOS, 20I2).

A Figura 9 apresenta gráficos comparativos da produção de sisal e valor bruto de produção (US\$), no período de 200I-20I I, no Brasil e no mundo. 
Figura 9 - Produção de sisal (toneladas) e valores brutos de produção (US\$), no período de 200I-20I I, no Brasil e no mundo (FAO, 20I3).
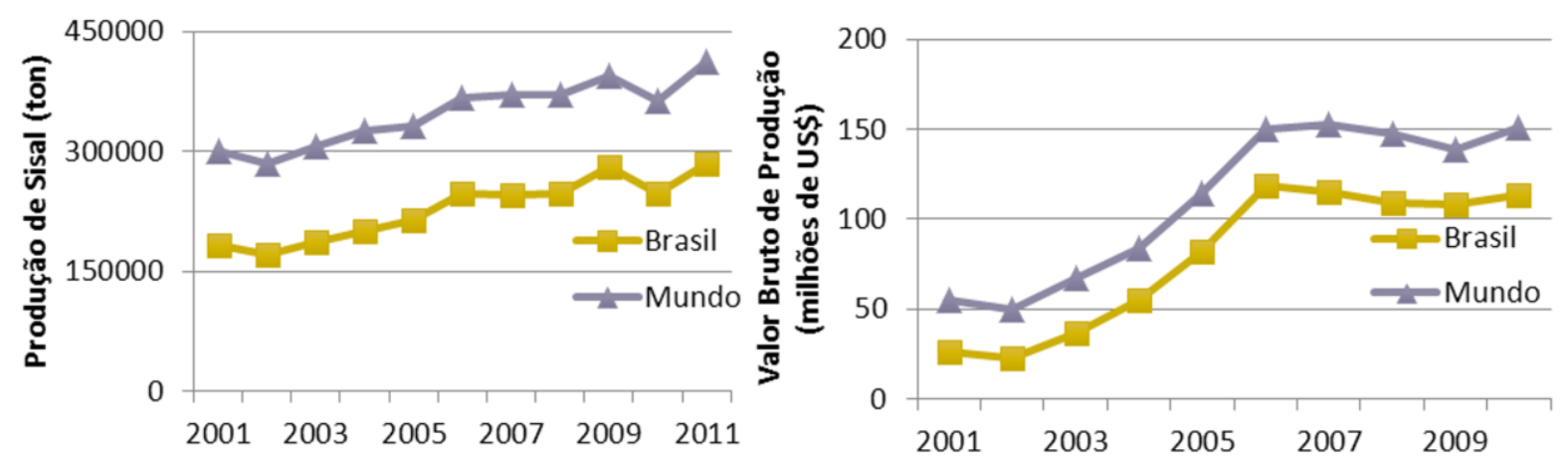

É observado que a produção de sisal tem crescido ao longo dos anos, sendo o Brasil responsável pela maior produção mundial (70\% e 68\% da produção mundial em 2009 e 20 I I, respectivamente) e um valor bruto de produção de US $\$$ I I 3.000.000 em 2010 (75\% do valor bruto mundial). O Estado da Bahia é responsável por $96 \%$ da produção de fibra nacional, seguido pelos estados de Pernambuco, Paraíba, Rio Grande do Norte e Ceará. Em 2010, a produtividade média de sisal, no estado da Bahia, beirou os $1.200 \mathrm{~kg} \mathrm{ha}^{-1}$. Assim, a cultura do sisal é de fundamental importância na economia nordestina, pois agrega valor às principiais regiões semiáridas do país, as quais apresentam escassas alternativas econômicas e baixo Índice de Desenvolvimento Humano (IDH). Os principais importadores da fibra de sisal produzida no país são, na ordem, os Estados Unidos, China, México e Portugal (DE OLIVEIRA SANTOS et al., 20I4).

Um problema de destaque associado ao sisal brasileiro é o preço praticado no mercado internacional. A Figura 10 apresenta gráficos comparativos, do período de 200I$20 \mathrm{II}$, relacionando a produção anual do sisal no Brasil e em alguns países africanos, os quais têm produção abaixo da média, e o valor bruto de venda. Observa-se que o Brasil tem uma produção anual muito superior aos países em questão, enquanto que o preço praticando pela tonelada é notoriamente inferior. 
Figura 10 - Comparativo da produção de sisal (toneladas) entre o Brasil e países com produção abaixo da média em relação aos valores brutos de mercado (US\$/tonelada), no período de 200I-20II (FAO, 20I3).
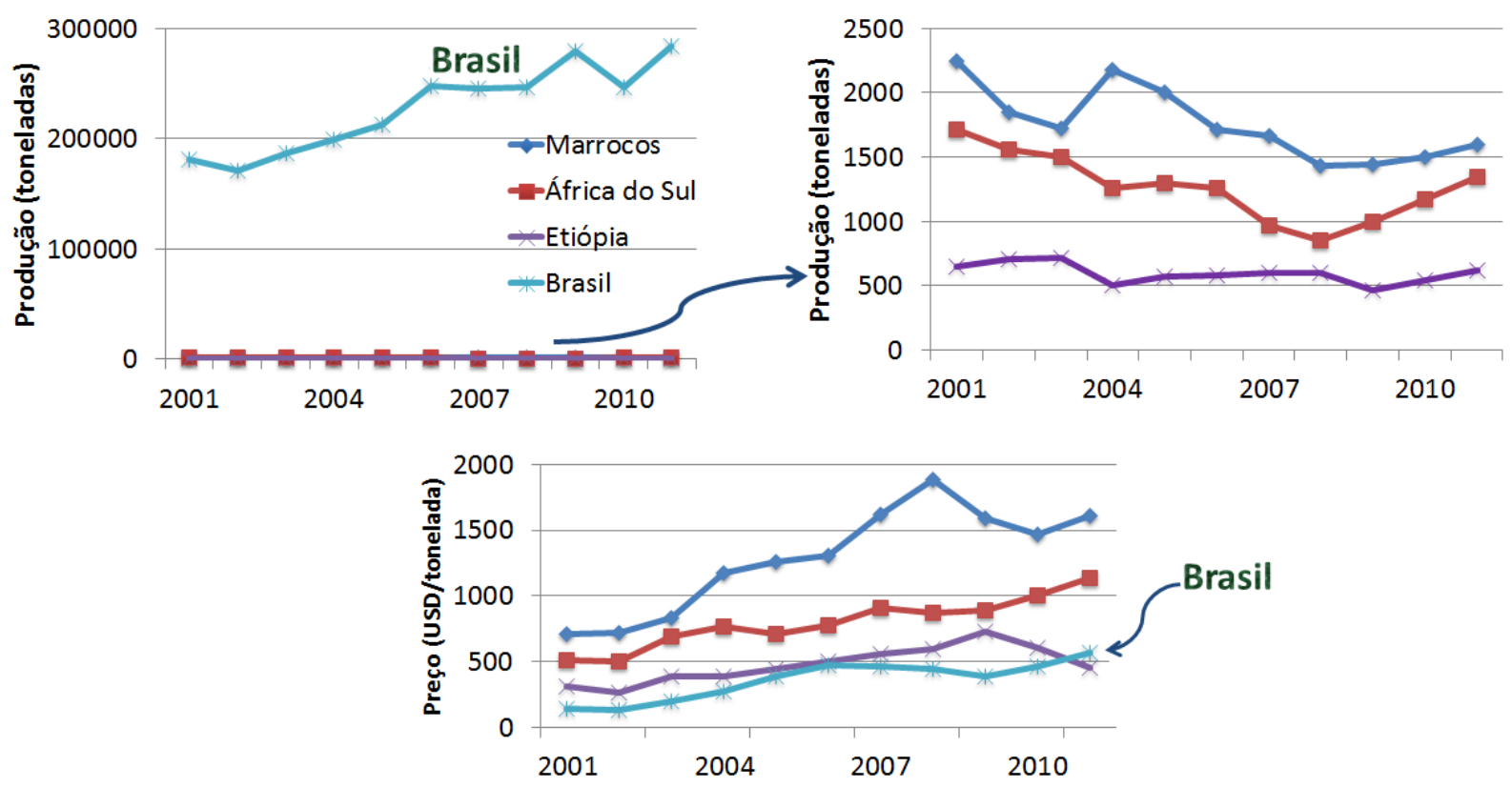

No presente trabalho, utilizou-se a fibra lignocelulósica de sisal e a celulose extraída a partir dela visando à valorização deste material, ao mesmo tempo tendo em vista a sua abundância no país, tratando-se de uma fonte lignocelulósica de rápido ciclo de crescimento e com alto teor de celulose (66-82\%) (MEGIATTO JR et al., 2008). 


\section{OBJETIVOS}

O objetivo central deste trabalho consistiu na valorização da fibra lignocelulósica de sisal, focando principalmente em seu componente majoritário, a celulose, como material de partida de sínteses e na preparação de materiais diversificados. Estudos de síntese em meios homogêneo (DMAc/LiCl) e heterogêneo foram considerados, visando identificar as melhores condições para a obtenção de ésteres de celulose de sisal de diferentes tamanhos de cadeia e diferentes graus de substituição (acetatos, butanoatos e hexanoatos). Posteriormente, os ésteres de celulose de sisal, preparados em meio homogêneo, foram considerados como materiais de partida na preparação de filmes (ésteres de celulose puros) e biocompósitos (ésteres de celulose/celulose de sisal), visando à obtenção de materiais com uma diversidade de propriedades finais e propriedades mecânicas superiores. A celulose de sisal foi também considerada com matéria-prima na preparação de microesferas (beads) e juntamente com a fibra lignocelulósica de sisal, ambas foram aplicadas como materiais de partida para a produção de nanofibras e fibras ultrafinas a partir da técnica de eletrofiação. 


\section{ESTRUTURAÇÃO DO TRABALHO}

Como já mencionado anteriormente, o presente trabalho foi estruturado em capítulos, os quais abordam diferentes aspectos envolvidos no uso das fibras de sisal. $O$ esquema a seguir mostra a organização escolhida para a apresentação dos resultados obtidos em cada etapa.

\section{Capítulo 1 \\ - Estudos sobre a preparação de ésteres de celulose em meios homogêneo e heterogêneo \\ Capítulo 2 \\ - Preparação e caracterização de filmes de ésteres de celulose e biocompósitos a partir de ésteres de celulose/celulose}

\section{Capítulo 3}

- Caracterização da superfície dos filmes e biocompósitos de ésteres utilizando técnicas avançadas: XPS, ToF-SIMS

\section{Capítulo 4}

- Preparação de microesferas de celulose de sisal

\section{Capítulo 5}

- Eletrofiação da fibra lignocelulósica de sisal e da celulose de sisal visando à obtenção de fibras ultrafinas e nanofibras 


\section{CAP I. ESTUDOS SOBRE A PREPARAÇÃO DE ÉSTERES DE CELULOSE DE SISAL EM MEIOS HOMOGÊNEO E HETEROGÊNEO}

\section{Introdução}

\section{I.I Celulose com o substrato em reações químicas: Derivatização em Meios Homogêneo e Heterogêneo}

A extensão da derivatização da celulose é usualmente caracterizada pelo seu grau de substituição (GS), o qual se refere ao número médio de hidroxilas celulósicas modificadas por UAG (Figura 2), podendo variar de 0 (celulose pura, não modificada) a 3 (celulose completamente modificada). As propriedades dos derivados de celulose são dependentes de inúmeros fatores, entre eles o GS, Grau de Polimerização (GP) e da distribuição dos substituintes ao longo da cadeia polimérica e dentro da UAG.

Em derivados parcialmente substituídos existem três possibilidades de não uniformidade na introdução dos grupos substituintes, como ilustra a Figura I I. A distribuição dos grupos funcionais dentro de uma UAG é governada pela acessibilidade estérica e pela diferença de reatividade entre os grupos hidroxila. $O$ impasse gerado pela insolubilidade da celulose em água e na maioria dos solventes orgânicos conhecidos é atribuído a sua estrutura supramolecular, razão pela qual a maioria dos produtos comerciais, hoje disponíveis no mercado, é produzida principalmente pela reação da celulose em estado sólido (reações heterogêneas, não envolvendo a solubilização da celulose). (KLEMM et al., 2004; FREIRE; GANDINI, 2006; WANG et al., 20I4). 
Figura II - Representação esquemática dos tipos de não uniformidade na derivatização da celulose.

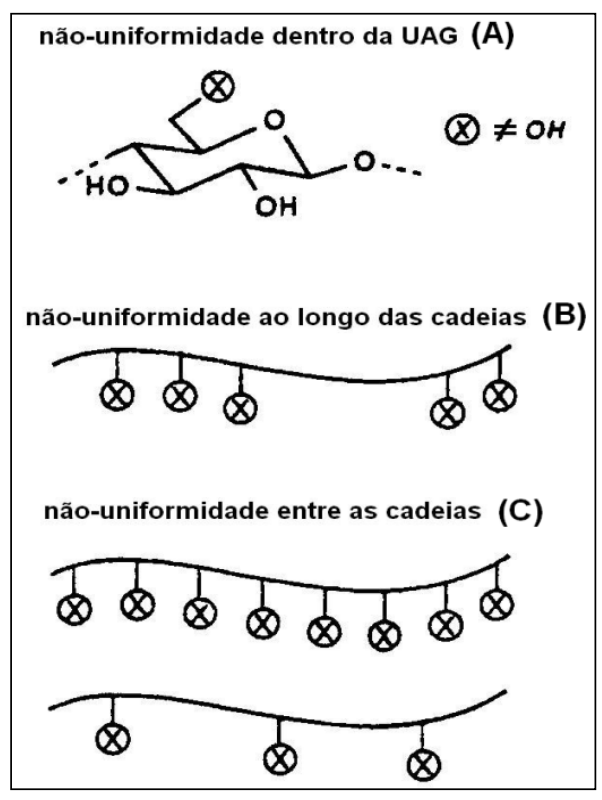

Industrialmente, grande parte dos ésteres de celulose é obtida em meio heterogêneo, por um processo em se utiliza uma solução de ácido acético e ácido sulfúrico/anidrido acético como sistema catalisador. No geral, em ambos os sistemas, homogêneo e heterogêneo, a estrutura supramolecular da celulose é completamente destruída e as propriedades físico-mecânicas das fibras de partida são perdidas após derivatização. Entretanto, em condições heterogêneas específicas, quando nem todos os grupos hidroxila das unidades UAG estão acessíveis para reação, ou mesmo quando a reação é interrompida mais cedo, a modificação poderá ocorrer principalmente na superfície da fibra e/ou nas regiões mais acessíveis das camadas internas da parede celular (FREIRE, C. S. R. et al., 2006). Assim, existe uma grande influência das características morfológicas e físico-químicas das fibras de partida, que irão determinar a acessibilidade dos reagentes aos seus sítios reativos, podendo-se citar o distanciamento dos feixes de fibras, cristalinidade, porosidade e a área de superfície exposta.

Nas reações do tipo heterogênea, envolvendo a celulose como substrato, a acessibilidade e reatividade dos grupos $\mathrm{OH}$ são também determinadas pelas etapas de ativação (onde ocorre a quebra das ligações hidrogênio), por meio de soluções alcalinas, como exemplo soluções de $\mathrm{NaOH}$, ou pela interação com o meio reacional (swelling) (KLEMM et al., 2004). O controle da ativação da celulose e o tipo de reação heterogênea permitem uma síntese efetiva de derivados celulósicos, com graus de substituição desejados 
e padrões de substituição reprodutíveis. Entretanto, há muitos aspectos importantes envolvendo os procedimentos de sínteses que ainda não são inteiramente entendidos, justificando assim a grande contribuição gerada nas últimas décadas em trabalhos envolvendo a celulose como material de partida (DAWSEY; MCCORMICK, 1990; HEINZE; LIEBERT, 200 I; LYND et al., 2002; KLEMM et al., 2005; QIU; NETRAVALI, 20I4).

Como explicado anteriormente, a derivatização em meio heterogêneo é influenciada principalmente pelos fatores estruturais que controlam a acessibilidade à celulose, como cristalinidade, porosidade e massa molar média, que podem variar dependendo da natureza da macromolécula, ou seja, a derivatização não será controlada somente pela reatividade das hidroxilas da celulose (PERES DE PAULA; LACERDA; FROLLINI, 2008). Neste meio não há solubilização da fibra, a qual permanece suspensa em uma solução da espécie química reagente. A reação ocorre por etapas, iniciando pelas regiões não cristalinas, mais acessíveis, e prosseguindo, gradualmente, para as regiões cristalinas. As cadeias de celulose localizadas na superfície devem ser primeiramente substituídas, como um todo ou parcialmente, para então serem solubilizadas no meio reacional, sendo que nas etapas intermediárias da reação, as moléculas terão regiões com alto grau de substituição, alternadas com regiões não substituídas.

Os recentes avanços envolvendo a modificação da celulose em meio heterogêneo são inúmeros e diversos exemplos ao longo da última década ilustram o constante potencial de crescimento nesta área. Pode-se citar funcionalização heterogênea deste biopolímero visando aplicações em compósitos (BOTARO; GANDINI; BELGACEM, 2005; FUJISAWA et al., 20|4); modificação de nanoceluloses visando à obtenção de novas funcionalidades (HABIBI, 20I4) ou aumento da adesão fibra-matriz em nanocompósitos (FUJISAWA et al., 20I4; LU et al., 20I4); obtenção controlada de fibras celulósicas modificadas com ácidos graxos (FREIRE, C. S. R. et al., 2006; FREIRE, CARMEN S. R. et al., 2006) ou mesmo inserção de longas cadeias alifáticas, via esterificação ou amidação, em cristais de nanoceluloses (BENDAHOU et al., 20I4); modificação de filmes de celulose visando à diminuição da molhabilidade da superfície (LI et al., 20I4).

Por meio do uso de solventes específicos para a celulose, os quais são responsáveis por "romper" as ligações hidrogênio, a influência da estrutura supramolecular da celulose na reação é eliminada. Neste contexto, uma solução contendo $\mathrm{LiCl}$ (sal inorgânico) e DMAc (solvente apolar aprótico) é considerada um dos sistemas mais importantes para a dissolução 
de celulose e posterior modificação química (DAWSEY; MCCORMICK, 1990), e tem sido um sistema de solvente muito utilizado na preparação de derivados de celulose (ASS; FROLLINI; HEINZE, 2004; ASS; CIACCO; FROLLINI, 2006; RAMOS, L. et al., 20II; MORGADO et al., 20I3; RODRIGUES et al., 20l4). Baixíssima degradação do polímero durante a funcionalização e uma alta taxa de recuperação do solvente por destilação são outros fatores que tornaram $\mathrm{DMAc} / \mathrm{LiCl}$ um sistema de solvente muito atrativo, ao longos dos anos, na preparação de variados derivados de celulose (REGIANI et al., 1999; RAMOS, L. et al., 20II; MORGADO et al., 20I3; RODRIGUES et al., 20I4). Outros solventes e sistemas de solventes também têm sido estudados nos últimos anos, tal qual a mistura binária contendo DMSO e TBAF, a qual demonstrou ser um bom sistema de solvente para celulose e muito eficiente nas sínteses em meio homogêneo (CIACCO et al., 2003; CASARANO et al., 201 I; WANG et al., 2013).

Várias propostas têm sido feitas, ao longo dos anos, procurando sistematizar os solventes para celulose conhecidos. Na Tabela I, são listados exemplos de solventes convencionalmente usados, incluindo orgânicos e inorgânicos (ATALLA; ISOGAI, 2005). 
Tabela I - Solventes convencionalmente usados na dissolução da celulose (ATALLA; ISOGAI, 2005).

\begin{tabular}{|c|c|c|}
\hline Categoria & Solvente & Observações \\
\hline Acido & $\begin{array}{l}>52 \% \mathrm{H}_{2} \mathrm{SO}_{4} \\
>85 \% \mathrm{H}_{2} \mathrm{SO}_{4}\end{array}$ & $\begin{array}{l}\text { Hidrólise Parcial } \\
\text { Hidrólise Parcial }\end{array}$ \\
\hline \multirow[t]{2}{*}{ Álcali } & \multirow[t]{2}{*}{$\begin{array}{c}6 \% \mathrm{LiOH} \\
6 \%-9 \% \mathrm{NaOH}\end{array}$} & $\begin{array}{l}\text { Necessita pré-tratamento da } \\
\text { celulose }\end{array}$ \\
\hline & & $\begin{array}{l}\text { Necessita pré-tratamento da } \\
\text { celulose }\end{array}$ \\
\hline \multirow{7}{*}{$\begin{array}{l}\text { Complexo } \\
\text { com } \\
\text { Metal } \\
\text { Acalino }\end{array}$} & $\mathrm{Cu}\left(\mathrm{NH}_{3}\right)_{4}(\mathrm{OH})_{2}$ [cuoxam] & \multirow{6}{*}{ Solução transparente } \\
\hline & $\mathrm{Cu}\left(\mathrm{H}_{2} \mathrm{NCH}_{2} \mathrm{CH}_{2} \mathrm{NH} 2\right)_{2}(\mathrm{OH})_{2}$ [cuen] & \\
\hline & $\mathrm{CO}\left(\mathrm{H}_{2} \mathrm{NCH}_{2} \mathrm{CH}_{2} \mathrm{NH}_{2}\right)_{2}(\mathrm{OH})_{2}$ & \\
\hline & $\mathrm{Ni}\left(\mathrm{NH}_{3}\right)_{6}(\mathrm{OH})_{2}$ & \\
\hline & $\mathrm{Cd}\left(\mathrm{H}_{2} \mathrm{NCH}_{2} \mathrm{CH}_{2} \mathrm{NH}_{2}\right)_{3}(\mathrm{OH})_{2}$ [cadoxen] & \\
\hline & $\mathrm{Zn}\left(\mathrm{H}_{2} \mathrm{NCH}_{2} \mathrm{CH}_{2} \mathrm{NH}_{2}\right)_{3}(\mathrm{OH})_{2}$ & \\
\hline & $\begin{array}{c}\text { Fe/3(ácido tartárico) } / 3 \mathrm{NaOH} \\
{[\mathrm{EWNN}]}\end{array}$ & Relativamente estável \\
\hline $\begin{array}{l}\text { Xantogenato } \\
\text { Alcalino }\end{array}$ & $\mathrm{CS}_{2} / \mathrm{NaOH}$ & Dissolve celulose formando viscose \\
\hline $\begin{array}{c}\text { Sal } \\
\text { inorgânico }\end{array}$ & $\begin{aligned} & >64 \% \mathrm{ZnCl}_{2} \\
> & 50 \% \mathrm{Ca}(\mathrm{SCN})_{2}\end{aligned}$ & $\begin{array}{l}\text { Dissolve celulose a } 100^{\circ} \mathrm{C} \\
\text { Dissolve celulose a } 100^{\circ} \mathrm{C}\end{array}$ \\
\hline \multirow{9}{*}{$\begin{array}{l}\text { Solventes } \\
\text { Orgânicos }\end{array}$} & $\mathrm{Cl}_{3} \mathrm{CHO} / \mathrm{DMF}$ & $\begin{array}{l}\text { Dissolve celulose, formando } \\
\text { hemiacetal cloral em todos os } \\
\text { grupos cel-OH }\end{array}$ \\
\hline & $\left(\mathrm{CH}_{2} \mathrm{O}\right)_{x} / \mathrm{DMSO}$ & $\begin{array}{l}\text { Dissolve celulose, formando (poli)- } \\
\text { metilol hemiacetais }\end{array}$ \\
\hline & $\mathrm{N}_{2} \mathrm{O}_{4} / \mathrm{DMF}, \mathrm{N}_{2} \mathrm{O}_{4} / \mathrm{DMSO}$ & $\begin{array}{c}\text { Dissolve celulose, formando nitritos } \\
\text { nos grupos cel-OH }\end{array}$ \\
\hline & LiCl/DMAc, LiCl/DMI & $\begin{array}{l}\text { Estável; pode necessitar pré- } \\
\text { tratamento da celulose }\end{array}$ \\
\hline & $\mathrm{SO}_{2} /$ amina/DMSO & $\begin{array}{c}\text { Instável; gera celulose regenerada } \\
\text { amorfa (estável) }\end{array}$ \\
\hline & $\mathrm{CH}_{3} \mathrm{NH}_{2} / \mathrm{DMSO}$ & $\begin{array}{l}\text { Dissolve celulose, formando } \\
\text { complexo }\end{array}$ \\
\hline & $\begin{array}{c}\mathrm{CF}_{3} \mathrm{COOH} \text { (ácido trifluoroacético: } \\
\text { TFA) }\end{array}$ & $\begin{array}{c}\text { Dissolve celulose, formando éster } \\
\text { TFA }\end{array}$ \\
\hline & $(\mathrm{Bu})_{4} \mathrm{~N}^{+} \mathrm{F}^{-} 3 \mathrm{H}_{2} \mathrm{O} / \mathrm{DMSO}$ & \\
\hline & $\begin{array}{l}\text { ca. } 80 \% \text { óxido de } \mathrm{N}- \\
\text { metilmorfolina/ } \mathrm{H}_{2} \mathrm{O}\end{array}$ & Usado na produção de lyocell \\
\hline \multirow[t]{2}{*}{ Outros } & $\mathrm{NH}_{4} \mathrm{SCN} / \mathrm{NH}_{3} /$ água & Forma estados mesofásicos \\
\hline & $\mathrm{N}_{2} \mathrm{H}_{4}$ & Explosivo \\
\hline
\end{tabular}

$\mathrm{Na}$ obtenção de derivados de celulose em meio homogêneo, três etapas são geralmente envolvidas: ativação, dissolução e subsequente reação da celulose com o agente derivatizante. Quando a celulose é solubilizada, as interações intermoleculares são rompidas 
e as cadeias se separam. A solubilização, portanto, permite o acesso das espécies reativas a um maior número de grupos funcionais presentes na cadeia, aumentando a substituição e tornando-a mais homogênea em relação à modificação heterogênea da celulose (KLEMM et al., 2004). As vantagens da derivatização da celulose em meio homogêneo decorrem principalmente do fato de que o GS do derivado de celulose pode ser mais eficientemente controlado, ajustando-se a razão molar do agente derivatizante à unidade anidroglicosídica (UAG) da celulose, e os grupos substituintes podem ser introduzidos com maior regularidade ao longo da cadeia polimérica (DAWSEY; MCCORMICK, 1990; EDGAR et al., 200I).

No presente trabalho, ésteres de celulose de sisal, com diferentes tamanhos de cadeia (acetatos, butanoatos e hexanoatos), foram preparados a partir de celulose de sisal em meio heterogêneo e homogêneo, neste último utilizando-se $\mathrm{DMAc} / \mathrm{LiCl}$ como sistema de solvente. Procurou-se estudar a influência do aumento da cadeia do agente esterificante na eficiência das reações, assim como a influência do aumento da cadeia lateral substituinte nas propriedades finais dos ésteres obtidos. Em meio heterogêneo, diferentes agentes acilantes (anidridos e cloretos ácidos) e catalisadores foram considerados. As eficiências das reações foram comparadas, no que diz respeito ao grau de substituição (GS) dos ésteres obtidos, levando em conta, por exemplo, tempo de reação e consumo de reagentes esterificantes. Posteriormente (Capítulos 2 e 3), os ésteres preparados em meio homogêneo foram utilizados como material de partida na preparação de filmes e biocompósitos (matriz de éster, reforço de celulose de sisal).

A celulose utilizada no presente trabalho foi submetida a um processo de tratamento alcalino, denominado mercerização, previamente a sua dissolução e posterior derivatização. Os aspectos envolvidos na escolha e utilização desse pré-tratamento serão discorridos na seção a seguir.

\section{I.2 Mercerização da celulose}

Em homenagem ao seu criador, John Mercer, o processo de tratamento da celulose com solução alcalina recebeu o nome de mercerização. Esta técnica consiste no tratamento 
das fibras com solução de hidróxido de sódio (agente intumescedor), em um faixa de concentração de 12 a 20\%. A mercerização da celulose é um processo irreversível que leva a uma modificação na estrutura supramolecular e na morfologia deste polissacarídeo (RAMOS, L. A. et al., 20II).

Este tratamento alcalino é uma etapa muito importante na produção de muitos derivados de celulose, uma vez que a celulose pode ser ativada por meio deste processo (MANSIKKAMÄKI; LAHTINEN; RISSANEN, 2005). Esta ativação, a qual objetiva o aumento da difusão dos reagentes na estrutura supramolecular da celulose, acontece pelo aumento da acessibilidade às regiões cristalinas e aos cristalitos presentes na superfície. Este aumento da acessibilidade é alcançado pela penetração inter e intracristalina do agente de ativação na celulose, neste caso íons de $\mathrm{Na}^{+}$, visando romper as intensas ligações hidrogênio entre as cadeias do polímero (EL SEOUD; NAWAZ; AREAS, 20I3).

O intumescimento da celulose pode ser de dois tipos: (I) intercristalino e (2) intracristalino. No primeiro caso, há penetração do agente intumescedor nas regiões não cristalinas das microfibrilas e nos espaços entre elas, enquanto que para o segundo caso, $\circ$ agente intumescedor penetra nas regiões cristalinas das microfibrilas. $O$ tratamento utilizado para a mercerização da celulose consiste em um intumescimento intracristalino limitado, utilizado para a acessibilidade da celulose a reagentes (SASSI; CHANZY, 1995). Assim, a mercerização da celulose ocorre na seguinte sequência: (I) agitação da amostra de celulose com solução de $\mathrm{NaOH}$ (12 a 20\%), (2) lavagem com água para remover o $\mathrm{NaOH}$, e (3) secagem da celulose tratada com álcali.

A mercerização ocorre com pequena degradação das cadeias, caso seja utilizado um tempo curto de tratamento e/ou se o oxigênio for eliminado do sistema ou se a temperatura for baixa (KLEMM et al., 2004). Uma das possíveis modificações que pode ocorrer nesse processo consiste na alteração cristalografia da celulose I para celulose II. Estas formas cristalográficas são decorrentes às diferentes conformações que o grupo hidroximetila $\left(-\mathrm{CH}_{2} \mathrm{OH}\right)$ pode assumir, o que gera duas diferentes estruturas de empacotamento das cadeias de celulose em um microcristal.

A celulose I, que é caracterizada por uma estrutura de cadeiras paralelas, ocorre quando os grupos $-\mathrm{CH}_{2} \mathrm{OH}$ de cadeias adjacentes se encontram na mesma conformação 
[Figura 12-(a)]. A celulose II, caracterizada por uma estrutura antiparalela, ocorre quando cadeias adjacentes possuem os grupos $-\mathrm{CH}_{2} \mathrm{OH}$ em diferentes posições [Figura I2-(b)].

Figura I2 - Projeções das celas unitárias da celulose no plano a, b: a) celulose I b) celulose II ligações hidrogênio (KROON-BATENBURG; KROON, 1997).

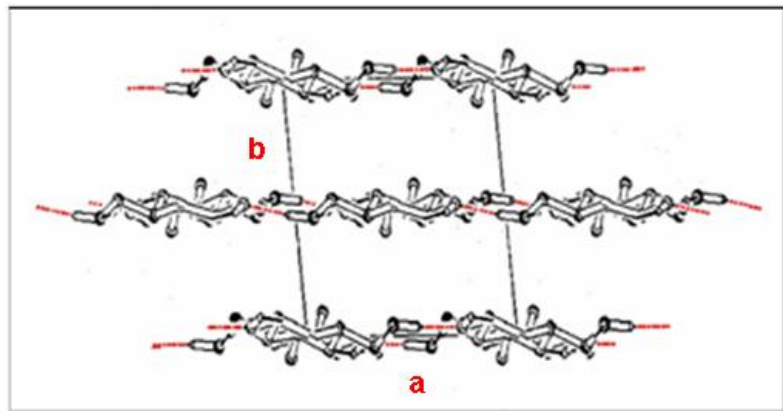

a) celulose I

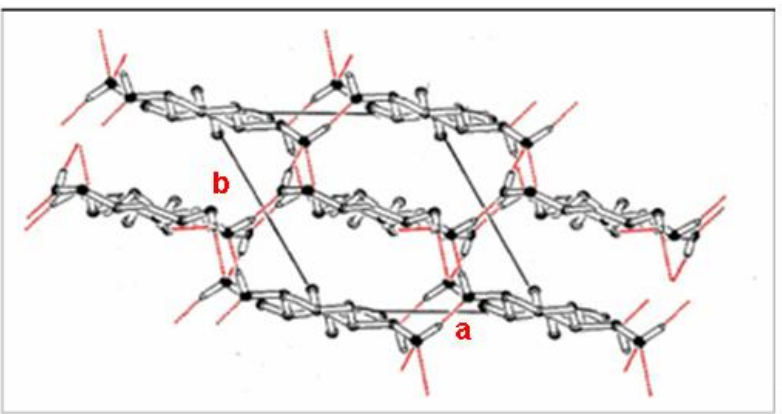

b) celulose II

O empacotamento antiparalelo [celulose II, Figura 12-(b)] permite a formação de ligações hidrogênio em maior extensão, formando arranjos em escala tridimensional e resultando numa estrutura mais estável e de menor energia. Este fato explica parcialmente porque a celulose II não pode ser revertida à celulose I (menos estável) (KROONBATENBURG; KROON, 1997).

Baseado em estudos de difração de raios $X$, foi proposto um mecanismo para a mercerização, no qual as regiões não cristalinas, seguida dos cristalitos menores e por último dos maiores, que compõe as cadeias da celulose I, incorporam íons sódio hidratado e hidróxido, formando estruturas cristalinas intermediarias de celulose alcalina, denominadas $\mathrm{Na}$-celulose. As cadeias de celulose I têm maior mobilidade, devido à solvatação por $\mathrm{Na}^{+} \mathrm{e}$ $\mathrm{OH}^{-}$, podendo então rotacionar em torno dos seus eixos, formando a estrutura de cadeias antiparalelas, característica da celulose II. Após a remoção do álcali, a celulose regenerada apresenta a estrutura da celulose II. Ainda, a cristalinidade da celulose pode diminuir após a mercerização desta, além de ocorrer afastamento dos feixes de fibras, sendo que ambos os fatores influenciam positivamente a dissolução deste polissacarídeo.

No presente trabalho, a celulose de sisal foi mercerizada, visando facilitar a dissolução no sistema de solvente considerado (DMAc/LiCl), assim como também para facilitar o acesso do agente esterificante à matriz polimérica, nas reações realizadas em meio heterogêneo. Como abordado anteriormente, a mercerização tem como objetivo ativar a celulose, propiciando maior difusão de solventes/reagentes na sua estrutura supramolecular, 
devido ao aumento da acessibilidade nas regiões cristalinas e dos cristalitos presentes na superfície.

\section{I.3 Sistema de solvente DMAc/LiCl}

O sistema de solvente DMAc/LiCl foi primeiramente descrito por MCCORMICK; LICHATOWICH (1979), sendo o mais frequentemente utilizado para a preparação de uma ampla variedade de derivados de celulose em meio homogêneo (ASS; CIACCO; FROLLINI, 2006; CRÉPY et al., 2009; MORGADO; MARTINS; et al., 20II; RODRIGUES et al., 20I4). Vários mecanismos de dissolução da celulose em DMAc/LiCl têm sido propostos ao longo dos anos. No geral, pode ser considerado que o mecanismo de dissolução compreende a formação de um complexo envolvendo íons do cloreto de lítio e as moléculas do solvente polar, os quais desempenham um importante papel na dissolução da celulose (MORGENSTERN; KAMMER, 1999), sendo este complexo entre lítio e DMAc descrito com um ânion cloreto livre, [Li.xDMAc] ${ }^{+} \mathrm{Cl}^{-}$(Figura I3; A, B, C e D).

Figura 13 - Esquemas de mecanismos propostos para o complexo [Li-DMAc] ${ }^{(+)} \mathrm{Cl}^{(-)} /$celulose $^{-}$ (DAWSEY; MCCORMICK, 1990).

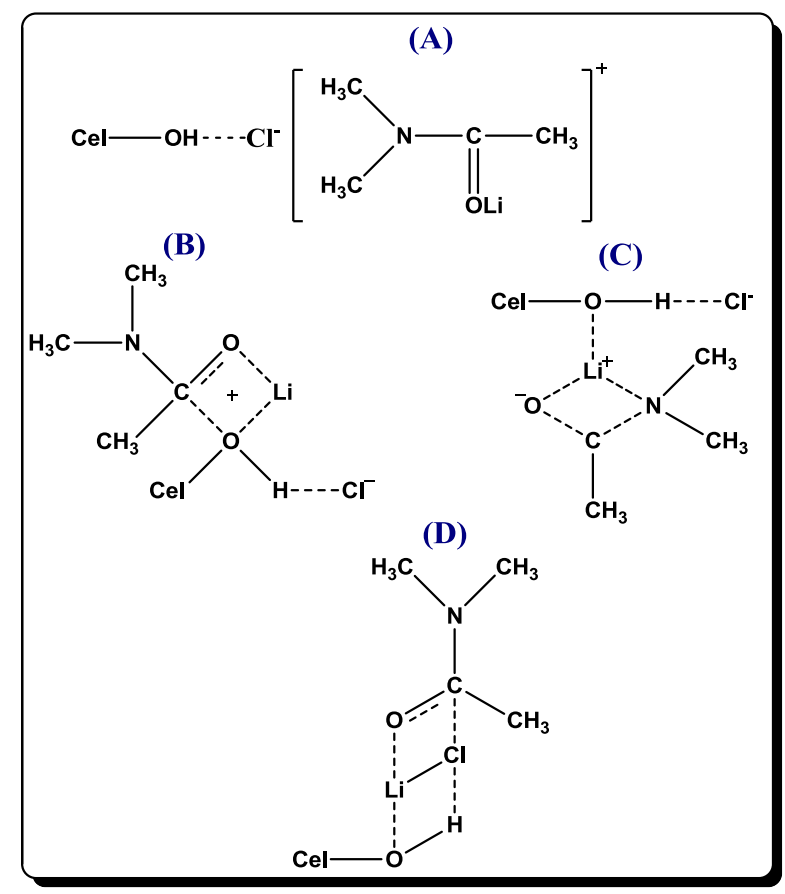


No esquema (A) (Figura I3), o ânion $\mathrm{Cl}^{(-)}$está associado com o próton hidroxílico da celulose e o macrocátion. O complexo $\mathrm{LiCl} / \mathrm{DMAc} /$ celulose, como proposto por ELKAFRAWY (1982) [Figura 13, esquema (B)], descreve o $\mathrm{Li}^{(+)}$associado com o oxigênio da carbonila da DMAc e ao oxigênio hidroxílico da celulose, deixando $\circ \mathrm{Cl}^{(-)}$livre. Segundo TURBAK (1984) [Figura 13, esquema (C)], o Li(+) está extensivamente complexado com átomos de oxigênio e nitrogênio da molécula de DMAc, bem como com o átomo de oxigênio da hidroxila celulósica. VINCENDON (1985) propôs uma estrutura "sanduíche" para o complexo [Figura I3, esquema (D)], no qual o $\mathrm{LiCl}$ se encontra não-dissociado (DAWSEY; MCCORMICK, 1990).

Em um estudo mais recente, ZHANG, C. et al. (2014) usaram a celobiose como modelo para o estudo das interações ocorridas no sistema celulose/DMAc/LiCl. Análises de condutividade, FTIR-ATR e RMN de ${ }^{13} \mathrm{C},{ }^{35} \mathrm{Cl}$ e ${ }^{7} \mathrm{Li}$ confirmaram que os pares iônicos $\mathrm{Li}^{+}-\mathrm{Cl}^{-}$, no sistema DMAc/LiCl, são separados quando a celobiose é dissolvida e resulta em um aumento de condutividade das soluções de celobiose/DMAc/LiCl. Os ânions de $\mathrm{Cl}^{-}$formam ligações hidrogênio com os prótons hidroxílicos da celobiose e não há indícios de interações óbvias entre os prótons hidroxílicos da celobiose e os grupos carbonilas presentes nas moléculas de DMAc. Com base nos resultados experimentais de ZHANG, C. et al. (20I4), o mecanismo de dissolução da celulose em $\mathrm{DMAc} / \mathrm{LiCl}$ foi proposto segundo o esquema mostrado na Figura 14. 
Figura 14 - Mecanismo de dissolução da celulose no sistema de solvente DMAc/LiCl proposto por ZHANG, C. et al. (20I4).

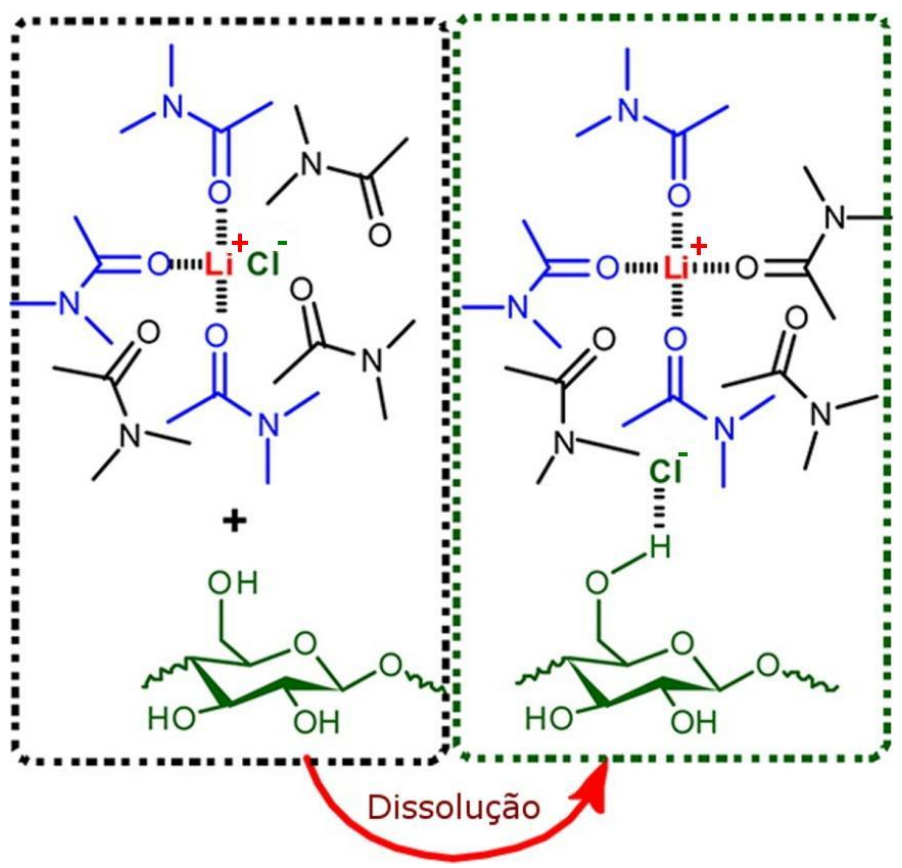

Os prótons hidroxílicos da celulose podem formam intensas ligações hidrogênio com os ânions $\mathrm{Cl}^{-}$, enquanto as ligações hidrogênio intermoleculares da rede da celulose são quebradas com simultânea separação dos pares iônicos $\mathrm{Li}^{+}-\mathrm{Cl}^{-}$. Assim, os cátions $\mathrm{Li}^{+}$ficam solvatados ainda mais pelas moléculas livres de DMAc e acompanham os ânions de $\mathrm{Cl}^{-}$que fazem ligações hidrogênio para atingir o equilíbrio eletroestático. Posteriormente, as cadeias de celulose podem se dispersas em nível molecular no sistema de solvente para formar uma solução homogênea (Figura 14).

No presente trabalho, utilizou-se DMAc/LiCl como sistema de solvente na dissolução e posterior esterificação da celulose. Novamente, ressalta-se que a baixíssima degradação do polímero durante a funcionalização e uma alta taxa de recuperação do solvente por destilação foram os principais fatores que tornaram esse sistema de solvente um excelente candidato. 


\section{I.4 Aplicação dos ésteres de celulose}

O grande interesse de converter a celulose em ésteres, e outros derivados, deve-se principalmente a dois motivos: (I) a celulose não é passível de processamento, i.e., a celulose decompõe antes que possa ocorrer fusão, sendo impossível seu processamento no estado fundido; (2) a celulose é insolúvel em água e na grande maioria dos solventes orgânicos. Nesta direção, a conversão da celulose em derivados ésteres abre uma grande janela de novos materiais, os quais, na maioria dos casos, podem ser processados no estado fundido e apresentam uma janela de solubilidade que vai desde solventes polares (água, etanol, metanol) até solventes orgânicos (EDGAR et al., 200 I; HEINZE; LIEBERT, 200I).

As aplicações dos ésteres de celulose se estendem desde a utilização como espessantes em cosméticos e produtos alimentícios, até membranas para controle de liberação de drogas, aditivos, adesivos ou na imobilização de biomoléculas (HO; WAUCHOPE, 2002; MOHAMMADI; SALJOUGHI, 2009; AMIM JR. et al., 20I0; LI et al., 2013). Desde a produção comercial de celulóide (classe de compostos criados a partir de nitrocelulose e cânfora), a aplicação dos ésteres de celulose tem sido na direção de materiais termoplásticos, sendo as investigações sempre direcionadas à criação de materiais com elevado desempenho mecânico e baseados em recursos renováveis (EDGAR et al., 200I; MORGADO; FROLLINI; et al., 20I I; ALMEIDA et al., 20I3). Estas investigações envolvem, por exemplo, a produção de ésteres de cadeia longa (RODRIGUES et al., 20/4) e desenvolvimento de blendas destes com outros polímeros (XU et al., 20I2). Os ésteres de celulose são largamente utilizados em compósitos e como ligante em laminados e camadas de laminados. Em combinação com fibras naturais, eles podem ser usados na preparação de compósitos, oriundos de matérias primas que levem, em alguns casos, a boa biodegradabilidade (EDGAR et al., 200I; MORGADO et al., 20I3).

Uma notável aplicação dos ésteres de celulose consiste no uso destes na preparação de membranas de separação e outros meios de separação (ZHAO et al., 2009; NATARA) et al., 20II; KIM et al., 20I3). Os acetatos de celulose, propionato de celulose e butanoato de celulose apresentam importantes aplicações na formulação de tintas e revestimento, à base de solventes orgânicos, visando melhorar as propriedades de fluxo (viscosidade), capacidade de polimento, resistência ao amarelamento, estabilidade à radiação UV, resistência a fissuras 
no filme e dispersão de pigmentos (EDGAR et al., 200I). Acetato de celulose e nitrato de celulose foram os primeiros materiais derivados de celulose a serem fabricados em forma de membranas. Garard (1927) já relatava o uso de membranas de acetato de celulose como meio de separação. Nos dias atuais, os ésteres de celulose são usados em praticamente todas as técnicas de separação, como relatado por Ghaemi (20I2), que recentemente aplicou membranas de nanofiltração, preparadas a partir de acetato de celulose, na separação de nitrofenóis. As membranas preparadas com estes ésteres de celulose cobrem praticamente todo o espectro de filtração de partículas, desde micro - ultrafiltração até nano-hiperfiltração (osmose reversa).

Ésteres de celulose de cadeias longa são amplamente estudados em vista do comportamento termoplástico apresentado por essa classe de materiais (GLASSER et al., 1999). Neste contexto, compósitos e nanocompósitos de celulose e seus derivados desempenham um importante papel como materiais substitutos daqueles oriundos de fonte não renovável (WU et al., 2009; JOHNSTON; NILSSON, 20I2; MORGADO et al., 20I3). Ésteres de celulose alifáticos, aromáticos, de cadeias volumosas, e com diferentes grupos funcionais presentes, estão disponíveis por meio de rotas sintéticas envolvendo ativação de ácidos livres com cloreto de tosila, $N, \quad N$ 'carbonilimizadol, sob meios homogêneos, envolvendo sistemas de solvente como DMAc/LiCl ou DMSO/TBAF (POHL et al., 2008; DORN et al., 2010; HALIDAN et al., 20I0; MAMAT et al., 2010). A partir disso, uma vasta gama de derivados celulósicos pode ser obtida, com diferentes graus de substituição, diferentes distribuições de substituintes e propriedades diversas (bioatividade, comportamento térmico e de dissolução variadas) (DORN et al., 20l0; HALIDAN et al., 2010; MAMAT et al., 2010). 


\section{Experimental}

Em todos os experimentos realizados utilizou-se polpa celulósica de sisal. A polpa utilizada foi gentilmente cedida pela empresa Lwarcel (Lençóis Paulista, SP), a qual foi obtida via processo Kraft e sequência de branqueamento do tipo ECF (Elemental Chlorine Free). Esse processo resultou em uma polpa de alvura ISO de $86 \%$ e comprimento e espessuras médios de 2,9 mm e 18,4 $\mu \mathrm{m}$, respectivamente (LACERDA; ZAMBON; FROLLINI, 20I3). O teor de lignina Klason foi determinado de acordo com a norma TAPPI T222-om-02, sendo que os resultados indicaram a ausência de lignina insolúvel (LACERDA; ZAMBON; FROLLINI, 20I3). Para todas as caracterizações, análises e experimentos, a polpa celulósica de sisal foi triturada em moinho (Marca Marconi, Modelo MA048) e seca em estufa de circulação a $105^{\circ} \mathrm{C}$, por $4 \mathrm{~h}$, antes de sua utilização.

Os solventes utilizados foram $\mathrm{N}, \mathrm{N}$-dimetilacetamida (Vetec)/cloreto de lítio (Vetec), metanol (Synth), trietilamina (Sigma-Aldrich) e cuproetilenodiamina (Synth). Como reagentes acilantes foram usados o anidrido acético (Mallinckrodt), anidrido butanóico (Sigma-Aldrich), anidrido hexanóico (Sigma-Aldrich) e cloreto de butanoíla (Sigma-Aldrich). Os anidridos foram destilados com pentóxido de fosfóro (Vetec) e armazenados na presença de peneira molecular $4 \AA$. Como catalisador para as reações heterogêneas utilizou-se iodo ressublimado (Hexis) e piridina (Sigma-Aldrich). O cloreto de butanoíla foi usado da maneira como recebido.

No tratamento alcalino (mercerização) e determinação do teor de alfa-celulose utilizou-se hidróxido de sódio (Qhemis). 


\section{I Pré-tratamento da celulose de sisal}

\section{I.I Mercerização}

Para se realizar a mercerização das fibras, utilizou-se de $20 \mathrm{~g}$ de celulose, as quais foram mantidas em suspensão em I $L$ de solução de hidróxido de sódio (20\% em massa), durante I h, sob agitação mecânica, a $0{ }^{\circ} \mathrm{C}$ (banho de gelo). $\mathrm{O}$ sobrenadante gerado foi então filtrado e lavado exaustivamente, até que a água atingisse $\mathrm{pH}$ igual ao da água de lavagem. Após sucessivas lavagens, secou-se a celulose à temperatura ambiente e levou-se a estufa com circulação de ar a $110^{\circ} \mathrm{C}$, por um período de $4 \mathrm{~h}$. Posteriormente, a amostra foi levada à estufa a vácuo, a $60^{\circ} \mathrm{C}$, por um período de $4 \mathrm{~h}$. Assim como realizado para a polpa celulósica de partida, a polpa de celulose mercerizada foi moída em moinho (Marca Marconi, Modelo MA048).

Em todas as reações (meio homogêneo/heterogêneo) utilizou-se a polpa de celulose de sisal mercerizada. Para fins práticos, durante a discussão, esta será tratada apenas como celulose de sisal mercerizada. Quando mencionado apenas celulose de sisal, esta irá se referir à polpa de celulose de partida.

\subsection{Caracterização da celulose de sisal e da celulose de sisal mercerizada}

\subsection{Avaliação dos comprimentos e tamanhos médios das fibras}

A fim de se avaliar o comprimento e espessura médios das fibras de celulose de sisal e de celulose de sisal mercerizada, usou-se um equipamento MorFi Compact (Techpap) (Figura 15), o qual detecta fibras até escala micrométrica. Este equipamento fornece uma 
análise em alta resolução para medidas de fibras em geral, com destaque para as fibras lignocelulósicas.

Figura 15 - Analisador de fibras (MorFi Compact - Techpap).

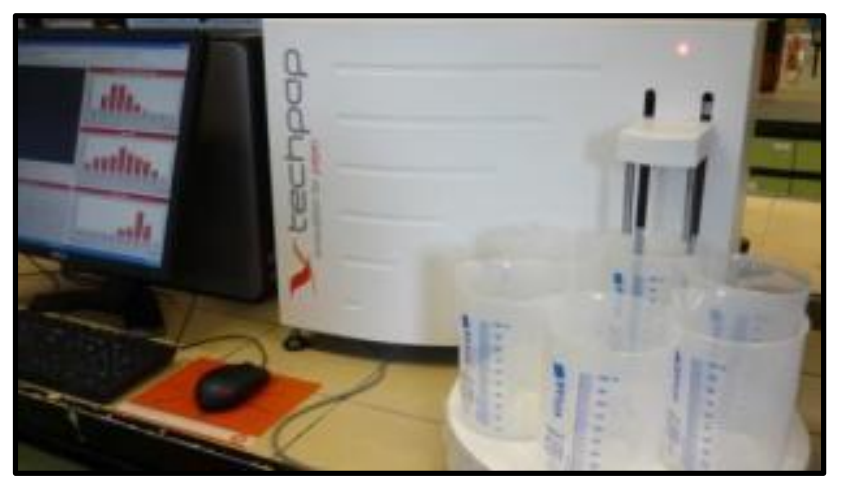

A análise, a qual é realizada em ambiente restrito apenas a fibras, permite uma medição estatística confiável de milhares de fibras em alta velocidade. Para a realização das análises, as fibras são suspensas em água.

\subsubsection{Determinação do teor de $\alpha$-celulose}

O teor de $\alpha$-celulose, o qual corresponde ao conteúdo de celulose pura na amostra, foi obtido por meio da diferença de massa das amostras antes e após o tratamento com uma solução de $\mathrm{NaOH}$ 17,5\%.

Adicionou-se $10 \mathrm{~mL}$ de uma solução de hidróxido de sódio 17,5\% (em massa) a I,0 g de celulose, a temperatura ambiente. Deixou-se em repouso por 2 min e, após esse período, a amostra foi macerada com um bastão de vidro por $8 \mathrm{~min}$. Após $10 \mathrm{~min}$ da primeira adição, adicionou-se mais $10 \mathrm{~mL}$ de solução de $\mathrm{NaOH}$, misturando-se bem e deixando-se em repouso por $20 \mathrm{~min}$. Em seguida, adicionou-se $40 \mathrm{~mL}$ de água destilada e filtrou-se a vácuo, usando um funil de vidro sinterizado (C), previamente seco e tarado. O material retido (celulose) foi lavado com $200 \mathrm{~mL}$ de ácido acético glacial diluído (20\%) e posteriormente com mais $200 \mathrm{~mL}$ de água destilada. Então, secou-se o funil contendo a $\alpha$-celulose a $110^{\circ} \mathrm{C}$, até a obtenção de uma massa constante. 


\subsubsection{Dosagem de hemicelulose na celulose de sisal mercerizada}

Pesou-se, em uma balança de infravermelho, I,0 g de celulose de sisal mercerizada e adicionou-se a um béquer de $25 \mathrm{~mL}$, juntamente com mais $10 \mathrm{~mL}$ de $\mathrm{H}_{2} \mathrm{SO}_{4} 72 \%$. A solução foi deixada, sob agitação, por $4 \mathrm{~h}$ a $20^{\circ} \mathrm{C}$. Após esse período, a solução foi transferida a um erlenmeyer de I L, adicionando-se $300 \mathrm{~mL}$ de água destilada. Essa solução foi deixada em refluxo por um período de $4 \mathrm{~h}$. Então, filtrou-se em funil de vidro sinterizado $n^{\circ} 3$, para eliminação dos sulfurados insolúveis, e enxaguou-se o funil com água destilada quente. Ao final, o volume do filtrado foi ajustado para $575 \mathrm{~mL}$ em um balão volumétrico. Uma alíquota da solução resultante foi retirada e analisada por HPLC, para a dosagem de açúcares simples. O teor de polissacarídeos foi determinado por meio da detecção dos seguintes compostos hidrolisados: celobiose, glicose, xilose, arabinose, ácido fórmico, ácido acético, furfural e hidroximetilfurfural (HMF). As condições da análise foram:

\section{Açúcares:}

- Cromatógrafo líquido - SHIMADZU.

- Detector: Índice de Refração - RID-6A.

- Coluna: Aminex HPX 87H (300 x 7,8 mm BIO-RAD).

- Eluente: $\mathrm{H}_{2} \mathrm{SO}_{4} 0,005 \mathrm{~mol} \mathrm{~L}{ }^{-1}$.

- Fluxo: $0,6 \mathrm{~mL} \mathrm{~min}^{-1}$.

- Temperatura: $45^{\circ} \mathrm{C}$.

\section{Furfural e HMF:}

- Cromatógrafo líquido - SHIMADZU.

- Detector: UV - 274nm, modelo SPD-IOAV.

- Coluna: $\mu$ Bondapak ${ }^{T M} C_{18}($ Waters $)$.

- Eluente: solução de acetonitrila/água I:8 (v/v), contendo ácido acético I\% (v/v).

- Fluxo: $0,8 \mathrm{~mL} \mathrm{~min}^{-1}$ 
- Temperatura: ambiente. Para a realização das medidas, foram usadas como padrões, concentrações variadas das seguintes substâncias: hidroximetilfurfural, furfural, celobiose, ácido glucurônico, glicose, xilose, arabinose, ácido fórmico e ácido acético.

\subsubsection{Determinação do índice de cristalinidade por raios $X$}

Para a determinação do índice de cristalinidade, foram obtidos os difratogramas de raios X, utilizando-se de uma unidade RINT2000 (Wide Angle Goniometer), com radiação de $\mathrm{Cu}$, linha $K, L=1,542 \AA$. A velocidade de varredura foi de $2^{\circ} \mathrm{min}^{-1}$ e as condições de uso foram $50 \mathrm{kV}$ e $100 \mathrm{~mA}$. O índice de cristalinidade foi calculado por meio da relação das intensidades do pico máximo e da linha base dos difratogramas obtidos. $O$ índice de cristalinidade pode ser dado pela equação de Buschle-Diller-Zeronian, Equação I (BUSCHLE-DILLER; ZERONIAN, 1992).

$$
I_{c}=1-\frac{I_{1}}{I_{2}} \quad \text { Eq. }[\mathrm{I}]
$$

Em que: $I_{1}$ é o valor da linha base do difratograma $\left(2 \theta\right.$ entre $18^{\circ}$ e $19^{\circ}$ para celulose I; $2 \theta$ entre $13^{\circ}$ e $15^{\circ}$ para celulose II), correspondente à parte não-cristalina da celulose e $I_{2}$ é o valor do pico de difração ( $2 \theta$ entre $22^{\circ}$ e $23^{\circ}$ para celulose I; $2 \theta$ entre $18^{\circ}$ e $22^{\circ}$ para celulose II), correspondente à parte cristalina. A celulose I, referida, corresponde à celulose nativa (polpa celulósica de partida), enquanto a celulose II é correspondente à celulose de sisal mercerizada.

\subsubsection{Análise do grau médio de polimerização viscosimétrico e massa molar média viscosimétrica}

Para essa análise, utilizou-se um viscosímetro do tipo capilar Ostwald, modelo Cannon Feske 150 (Shop Lab), a 25 C (temperatura controlada por um banho de água e 
circulador termostático 2095 Masterline ${ }^{\mathrm{TM}}$ Forma Scientific). Utilizou-se cuproetilenodiamina (CUEN) como solvente. Todas as medidas foram realizadas em duplicata.

Mediu-se, por três vezes, o tempo de escoamento de um sistema solvente/água, na proporção I:I em volume. Em seguida, mediu-se, também por três vezes, o tempo de escoamento de uma solução de $10 \mathrm{~mL}$ de CUEN, $10 \mathrm{~mL}$ de água e $0,03 \mathrm{~g}$ de celulose triturada em moinho (Marconi, modelo MA-048). Calculou-se o grau de polimerização viscosimétrico médio, $\left(G P_{v i s}\right)$, a partir dos valores de viscosidade intrínseca [n], com o auxílio da equação de Mark-Houwink Sakurada, Equação 2 (TAPPI, 1990). A partir desse valor de grau de polimerização viscosimétrico médio, calculou-se a massa molar viscosimétrica média, correspondente a $M M_{v i s}=G P_{v i s} x 162$, onde 162 é a massa de uma UAG.

$$
G P_{v i s}{ }^{0,905}=0,75 \eta \quad \text { Eq. [2] }
$$

\subsubsection{Espectrometria na região do infravermelho}

Para a obtenção dos espectros na região do infravermelho, utilizou-se de um equipamento da marca BOMEM, modelo MB-102. As pastilhas foram preparadas na proporção de I mg de amostra para $100 \mathrm{mg}$ de brometo de potássio $(\mathrm{KBr})$.

\subsubsection{Microscopia Eletrônica de Varredura}

Para as análises de Microscopia Eletrônica de Varredura (equipamento EVO 50 ZEISS), as amostras foram colocadas sobre uma fita adesiva de carbono, em porta amostras de alumínio, recobertas com uma fina camada de ouro (material condutor), utilizando-se para o recobrimento o equipamento Coating System MED 020 Baltec. 


\subsubsection{Análise Termogravimétrica (TG)}

As análises termogravimétricas foram realizadas em um analisador termogravimétrico Shimadzu TGA - 50 sob atmosfera de $\mathrm{N}_{2}$, com um fluxo de gás de $20 \mathrm{~mL} \mathrm{~min}^{-1}$, a uma razão de aquecimento de $20^{\circ} \mathrm{C} \mathrm{min}^{-1}$. $\mathrm{O}$ intervalo de temperatura foi de 25 a $700^{\circ} \mathrm{C}$. A massa de amostra foi cerca de $8,0 \mathrm{mg}$, tendo sido utilizado um porta amostra de platina.

\subsection{Síntese dos ésteres de celulose}

\subsection{Meio homogêneo}

\subsection{I.I Dissolução em DMAc/LiCl}

A etapa de dissolução, assim como a etapa de esterificação (item 2.3.I.2), seguiram condições estabelecidas em trabalhos anteriores (ASS; CIACCO; FROLLINI, 2006; RAMOS, L. et al., 20II; MORGADO et al., 20I3). Para a solubilização, foram utilizadas as amostras de celulose mercerizadas. Estas foram secas em estufa a vácuo a $60^{\circ} \mathrm{C}$, por $3 \mathrm{~h}$. $\mathrm{O}$ cloreto de lítio foi seco em estufa a vácuo, a $110^{\circ} \mathrm{C}$, por uma noite. Posteriormente, ambos foram armazenados em dessecador. O DMAc utilizado foi previamente destilado e armazenado em presença de peneira molecular $4 \AA$.

Utilizou-se um balão de quatro bocas, agitador mecânico, condensador de refluxo, funil de adição (sem braço lateral de equalização), banho de óleo (canola) para aquecimento e fluxo de nitrogênio (Figura 16). 
Figura 16 - Representação esquemática das etapas do processo de solubilização da celulose.

(a)

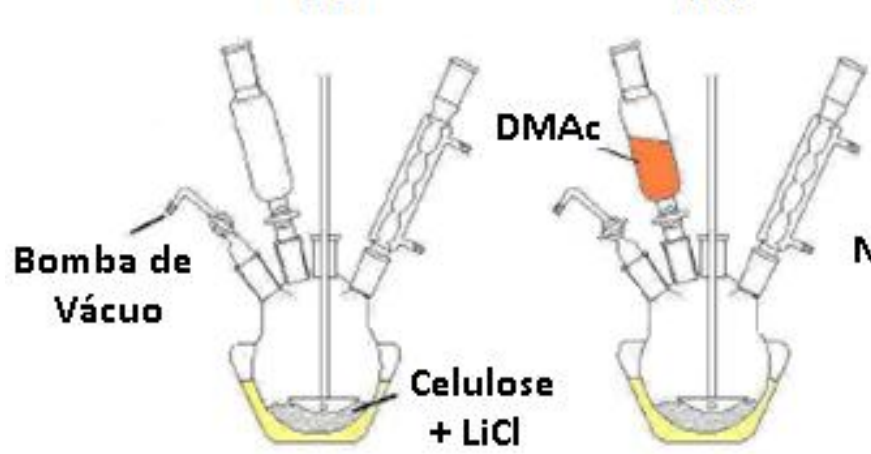

(c)

Nitrogênio

Adicionou-se ao balão 2,0 g de celulose mercerizada e 5,0 g de $\mathrm{LiCl}$. A temperatura do sistema foi elevada a $110^{\circ} \mathrm{C}$, sob vácuo e com agitação mecânica, e mantida nesta temperatura durante I h [Figura I6-(a)]. Após esse tempo, adicionou-se 100,0 mL de DMAc em refluxo, sob pressão reduzida [Figura 16-(b)]. O sistema foi então conectado a uma linha de nitrogênio seco e, após equalização da pressão interna com $\mathrm{N}_{2}$, a tampa do condensador foi substituída por um tubo secante [Figura 16-(c)]. O sistema foi aquecido a $160{ }^{\circ} \mathrm{C}$, sob intensa agitação, por 4 h. Após este período, o sistema foi resfriado lentamente, mantendose a agitação por um período de $24 \mathrm{~h}$.

\subsubsection{Esterificação}

Após o período de $24 \mathrm{~h}$ de agitação, obteve-se uma solução homogênea e transparente de celulose em $\mathrm{DMAc} / \mathrm{LiCl}$. Então, a temperatura do sistema foi elevada a $110^{\circ} \mathrm{C}$, adicionando-se o reagente acetilante desejado (anidrido acético, anidrido butanóico ou anidrido hexanóico) em diferentes razões molares $\left(\mathrm{Mol}_{\text {Anidrido }} / \mathrm{Mol}_{\mathrm{AGU}}\right)$. O sistema foi mantido nesta temperatura por $4 \mathrm{~h}$. Em seguida, resfriou-se a temperatura ambiente, adicionando-se metanol para precipitar o produto. Realizou-se a filtração sob pressão reduzida e lavou-se o produto com metanol durante dois dias, realizando filtrações sucessivas. Os ésteres foram secos em estufa a vácuo a $60^{\circ} \mathrm{C}$ até massa constante e moídos em um moinho de facas analítico (Analysenmühle A 10 Janke \& Kunkel). A razão molar supracitada relaciona a quantidade (expressa em número de mol) de agente esterificante 
usado em relação a uma unidade anidroglicosídica, isto é, a estrutura fundamental de repetição da celulose, a qual contém três grupos hidroxila e massa molar de 162. Assim, por exemplo, visando-se obter um GS estequiométrico de 3 (completamente substituído), escolher-se-ia uma razão $\mathrm{Mol}_{\text {Anidrido }} / \mathrm{Mol}_{\mathrm{AGU}}=3$ (na qual $3 \mathrm{~mol}$ de agente esterificante seriam usados na esterificação dos três grupos hidroxila).

\subsubsection{Meio heterogêneo}

Para as sínteses em meio heterogêneo, utilizou-se um sistema com um balão de três bocas, agitador mecânico, condensador de refluxo e banho de óleo (canola) para aquecimento e fluxo de nitrogênio (Figura I7).

Figura 17 - Modelo do sistema de acetilação da celulose em meio heterogêneo. A) banho de óleo; B) Balão de nitrogênio; C) Condensador de refluxo; D) Agitador mecânico.

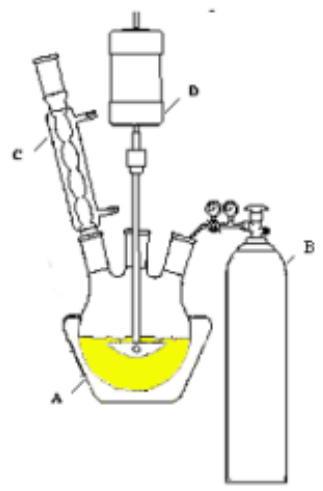

Em um primeiro momento, testou-se um sistema composto por anidrido ácido (agente esterificante) e iodo metálico (catalisador). Para estes testes, anidrido acético e butanóico foram escolhidos como agentes esterificantes de partida.

Em um balão, adicionou-se $1,0 \mathrm{~g}(6,17 \mathrm{mmol})$ de celulose mercerizada suspensa em $17,0 \mathrm{~mL}$ do agente esterificante, elevando-se a temperatura até $110^{\circ} \mathrm{C}$. Adicionou-se então $0,05 \mathrm{~g}$ de iodo metálico ressublimado $(0,20 \mathrm{mmol})$. O tempo de reação utilizado foi variado (desde $10 \mathrm{~min}$, até $18 \mathrm{~h}$ para o anidrido butanóico), com a finalidade de se obter ésteres com diferentes graus de substituição. Ao final de cada reação, resfriou-se o sistema à temperatura ambiente e adicionou-se $2 \mathrm{~mL}$ de solução saturada de tiossulfato de sódio, a fim 
de reduzir $\circ \mathrm{I}_{2}$ a iodeto (observando-se a mudança da cor da reação de marrom para amarelo pálido). Ao final, adicionou-se à solução $100 \mathrm{~mL}$ de metanol, deixando sob agitação por I h, filtrando em seguida. Posteriormente, repetiu-se o procedimento, lavando novamente com metanol por mais I h, seguido da filtração. Lavou-se o produto final com água e deixou-se secar em estufa de circulação à $105^{\circ} \mathrm{C}$ por $2 \mathrm{~h}$, e por fim em estufa a vácuo a $60^{\circ} \mathrm{C}$, até massa constante (PERES DE PAULA; LACERDA; FROLLINI, 2008).

Em um segundo momento, testou-se diversos sistemas visando à obtenção de butanoatos de celulose a partir do uso do correspondente anidrido ácido ou cloreto ácido. Como catalisadores, considerou-se o iodo e a piridina. Em alguns sistemas, DMF foi utilizado como um agente de swelling. Inicialmente, em balão à temperatura ambiente, adicionou-se 0,5 g (3,8 mmol) de celulose de sisal mercerizada. Diferentes tipos de sistemas foram levados em consideração.

A celulose $(0,5 \mathrm{~g})$ suspensa em piridina $(15 \mathrm{~mL})$, à temperatura ambiente, mantendo o sistema sob intensa agitação. Adicionou-se, então, ao balão, anidrido butanóico $(5 \mathrm{~mL})$, gota a gota. A temperatura foi elevada a $80{ }^{\circ} \mathrm{C}$, mantendo-se rigorosa agitação. Após esse tempo foi adicionado iodo metálico (50 mg, catalítico). $O$ tempo de reação utilizado foi de $3 \mathrm{~h}$.

(ii) A celulose $(0,5 \mathrm{~g})$ suspensa em piridina ( $15 \mathrm{~mL})$, à temperatura ambiente, mantendo o sistema sob intensa agitação. Adicionou-se, então, ao balão, cloreto de butanoíla $(5 \mathrm{~mL})$, gota a gota. A temperatura foi elevada a $80{ }^{\circ} \mathrm{C}$, mantendo-se rigorosa agitação. $\mathrm{O}$ tempo de reação utilizado foi variado (30 $\mathrm{min})$.

(iii) Um equivalente (referente ao total de grupos $\mathrm{OH}$ da celulose) de cloreto de butanoíla foi adicionado a um balão. Então, $25 \mathrm{~mL}$ de DMF, seguido de piridina ( $\mathrm{l}$ eq.) e finalmente celulose $(0,5 \mathrm{~g})$ foram adicionados. A temperatura foi elevada a $110{ }^{\circ} \mathrm{C}$, mantendo-se rigorosa agitação. $O$ tempo de reação utilizado foi variado (I-3 h).

(iv) Um equivalente (referente ao total de grupos $\mathrm{OH}$ da celulose) de anidrido butanóico foi adicionado a um balão. Então, $25 \mathrm{~mL}$ de DMF e celulose $(0,5 \mathrm{~g})$ foram adicionados. A temperatura foi elevada a $110{ }^{\circ} \mathrm{C}$, mantendo-se rigorosa agitação. $O$ tempo de reação utilizado foi de $3 \mathrm{~h}$. 
Um equivalente (referente ao total de grupos $\mathrm{OH}$ da celulose) de anidrido butanóico foi adicionado a um balão. Então $25 \mathrm{~mL}$ de DMF, seguido de piridina ( $\mathrm{I}$ eq.) e finalmente celulose $(0,5 \mathrm{~g})$ foram adicionados. A temperatura foi elevada a $110{ }^{\circ} \mathrm{C}$, mantendo-se rigorosa agitação. $\mathrm{O}$ tempo de reação utilizado foi de $3 \mathrm{~h}$.

Ao final de cada reação, o sistema foi resfriado à temperatura ambiente, adicionando à solução $200 \mathrm{~mL}$ de etanol e deixando sob agitação por I h. Após esse período, as soluções foram filtradas, repetindo-se o procedimento e finalmente lavando com etanol por mais I h, seguido de filtração. Os produtos foram secos em estufa de circulação a $80^{\circ} \mathrm{C}$ por $4 \mathrm{~h}$, e por fim em estufa a vácuo a $60^{\circ} \mathrm{C}$, até massa constante.

\subsubsection{Caracterização dos ésteres de celulose}

\subsubsection{Grau de Substituição (RMN 'H)}

O grau de substituição (GS) é um indicativo do número médio de substituintes por unidade de anidroglicose (UAG). Pode-se calcular o GS por meio da relação entre a área correspondente à ressonância dos átomos de hidrogênio do anel de glicose $(\delta \sim 2,90-5,10$ PPm) e a área correspondente à ressonância dos átomos de hidrogênio do grupo metila do da cadeia éster correspondente $(\delta \sim 1,70-2,20$ ppm), podendo ser obtido por meio da Equação 3.

$$
G S=\frac{7 x I_{H, m e t i l a}}{3 x I_{H, U A G}} \mathrm{Eq} .[3]
$$

Sendo $\mathrm{I}_{\mathrm{H} \text {, metila }}$ integral do pico dos hidrogênios metílicos do substituinte éster.

$\mathrm{I}_{\mathrm{H}, \text { UAG }}$ : integral do pico dos hidrogênios da unidade anidroglicosídica. 


\subsubsection{Difração de raios $X$}

Os difratogramas dos ésteres de celulose foram obtidos utilizando-se de uma unidade RINT2000 (Wide Angle Goniometer), com radiação de $\mathrm{Cu}$, linha $K, \mathrm{~L}=1,542 \AA$. A velocidade de varredura foi de $2^{\circ} \mathrm{min}^{-1}$ e as condições de uso foram $50 \mathrm{kV}$ e $100 \mathrm{~mA}$. 


\section{Resultados e Discussão}

\section{I Caracterização da celulose de partida}

Pré-tratamentos na massa celulósica podem provocar mudanças em sua estrutura morfológica, tal como desagregação das fibras agregadas, intumescimento, separação das fibrilas e consequente aumento da superfície acessível. Desta maneira, estes tratamentos podem afetar propriedades que incluem não só as morfológicas, mas também térmicas, teor de a-celulose, grau de polimerização e cristalinidade (KLEMM et al., 2004; MOSIER et al., 2005; RAMOS et al., 2005).

Nesta direção, os resultados a seguir visam avaliar em qual extensão o processo de mercerização, aplicado à celulose de sisal utilizada no presente trabalho, afetou os parâmetros supracitados. Ressalta-se, mais uma vez, que a mercerização foi utilizada como um pré-tratamento na celulose visando facilitar a sua dissolução em $\mathrm{DMAc} / \mathrm{LiCl}$ e também visando facilitar o acesso de agentes esterificantes, nas reações realizadas em meio heterogêneo.

\section{I.I Avaliação dos comprimentos e tamanhos médios das fibras}

A fim de se avaliar o efeito da mercerização nos comprimentos e espessuras das fibras contidas na polpa de sisal, esta foi analisada antes e pós-tratamento alcalino (mercerização). Na Figura 18 constam os mapas tridimensionais de densidade, os quais representam a distribuição das fibras de acordo com seus comprimentos e espessuras, para a celulose de sisal e celulose de sisal mercerizada, em uma análise feita em um analisador de fibras (MorFi Compact - Techpap, Figura I5), pela medida de aproximadamente 5000 fibras. 
Figura 18 - Mapas de densidade da distribuição de comprimento/espessura das fibras de celulose de sisal e de celulose de sisal mercerizada.
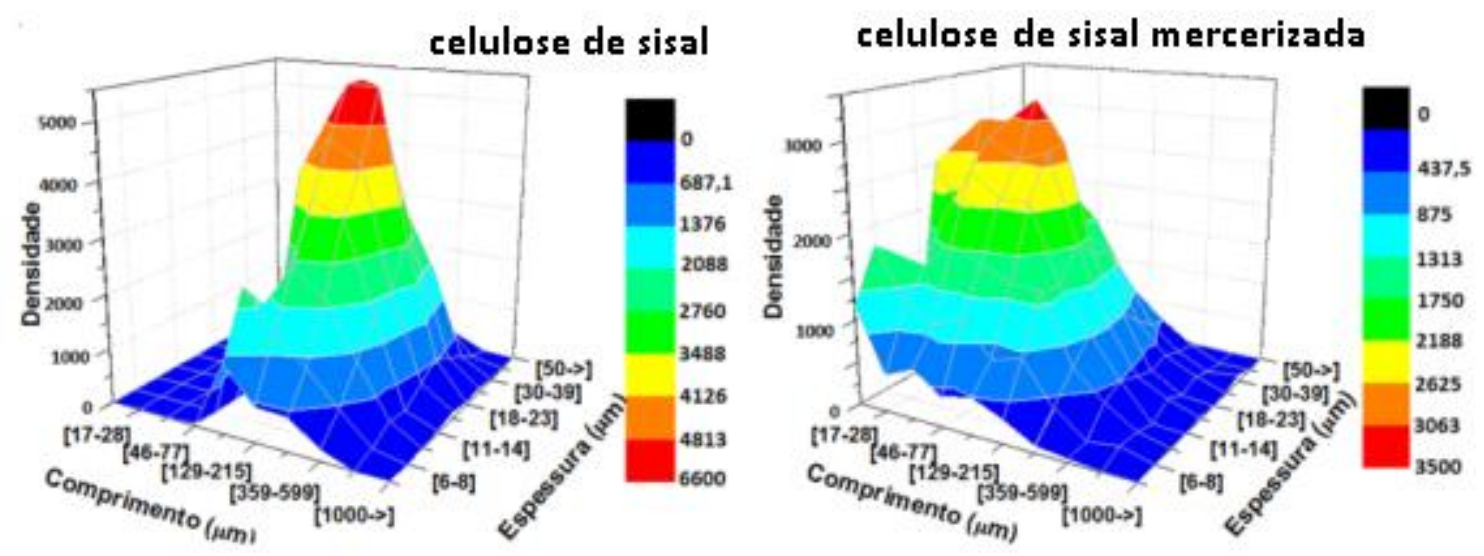

Observa-se que, para o mapa de distribuição da celulose de sisal mercerizada, há uma grande densidade de fibras nas regiões de menor comprimento (I7-77 $\mu \mathrm{m})$, região na qual praticamente a densidade de fibras era nula na polpa de sisal sem tratamento. Consequentemente, a região de maior comprimento de fibras (359-1000 $\mu \mathrm{m}$ ) apresentou menor densidade na celulose mercerizada, demonstrando que, de fato, o tratamento alcalino realmente levou a fibras menores. O mesmo efeito, ainda que menos pronunciado, é observado para as espessuras das fibras de sisal pré e pós-mercerização, onde após o tratamento alcalino houve o aumento da densidade de fibras nas regiões de menor espessura (6-23 $\mu \mathrm{m})$ em relação à celulose de sisal nativa, a qual apresentou maior densidade nas regiões de maior espessura ( I l-39 $\mu \mathrm{m})$.

\section{I.2 Espectroscopia na região do infravermelho}

Os espectros na região do infravermelho (Figura 19) para as amostras de celulose de sisal, antes e após mercerização, foram obtidos para fins comparativos. 
Figura 19 - Espectros na região do infravermelho para as amostras de celulose de sisal e celulose de sisal mercerizada.
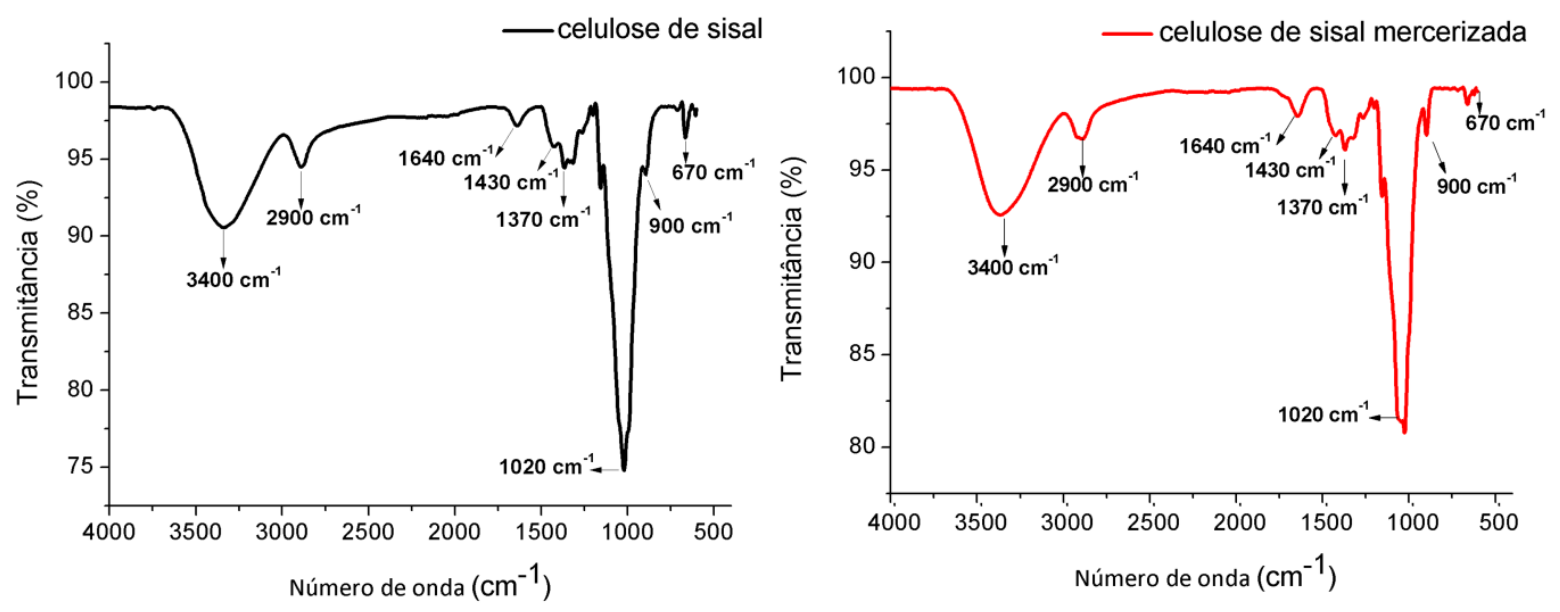

Podem-se observar, nos espectros de FTIR para a celulose de sisal antes e após mercerização (Figura 19), bandas características de um típico material celulósico, tais como: estiramento da ligação $\mathrm{O}-\mathrm{H}$ dos grupos hidroxílicos em $3400 \mathrm{~cm}^{-1}$; adicionalmente, pode-se observar a deformação da ligação $\mathrm{O}-\mathrm{H}$ dos grupos hidroxílicos provenientes de água adsorvida em $1640 \mathrm{~cm}^{-1}$; estiramento da ligação C-H em $2900 \mathrm{~cm}^{-1}$; vibrações de deformação no plano das ligações H-C-H e O-C-H em $1430 \mathrm{~cm}^{-1}$; vibração de deformação de ligações C$\mathrm{H}$ em $1370 \mathrm{~cm}^{-1}$; vibração de estiramento de ligações C-O do esqueleto celulósico em 1020 $\mathrm{cm}^{-1}$; vibrações de deformação e estiramento das ligações C-O-C, C-C-O e C-C-H dos átomos de C-5 e C-7 em $900 \mathrm{~cm}^{-1}$; deformação fora do plano da ligação C-OH em $670 \mathrm{~cm}^{-1}$.

Pela similaridade apresentada pelos dois espectros, pode-se concluir que $\circ$ tratamento com solução aquosa alcalina, no qual a celulose é submetida no processo de mercerização, não provoca alteração na estrutura química da celulose. No entanto, segundo OUAJAI; SHANKS (2009), alterações estruturais decorrentes da conversão de celulose I (paralela) para celulose II (antiparalela), como efeito da mercerização neste caso, podem ser observadas por meio de uma ligeira alteração na intensidade de vibração da banda em 900 $\mathrm{cm}^{-1}$, a qual pode ser observada na Figura 19. 


\section{I.3 Determinação do índice de cristalinidade (difração de raios $X$ )}

Os difratogramas das amostras de celulose antes e após mercerização foram obtidos e, a partir destes, calculou-se os índices de cristalinidade das amostras a partir da Equação I (Tabela 2). O difratograma da celulose de sisal (Figura 20) apresentou difrações típicas da forma polimórfica da celulose I, sendo estas difrações em 20: $23^{\circ}$ (plano 002), $21^{\circ}$ (plano 02I), $17^{\circ}$ (plano 10I). O difratograma da celulose de sisal mercerizada (Figura 20) apresentou difrações típicas da forma polimórfica da celulose II, com difração em 20: $20^{\circ}$ (plano I0I), $22^{\circ}$ (plano 002), $13^{\circ}$ (plano I0I).

Figura 20 - Difratogramas de raios $X$ das amostras de celulose de sisal e celulose de sisal mercerizada.

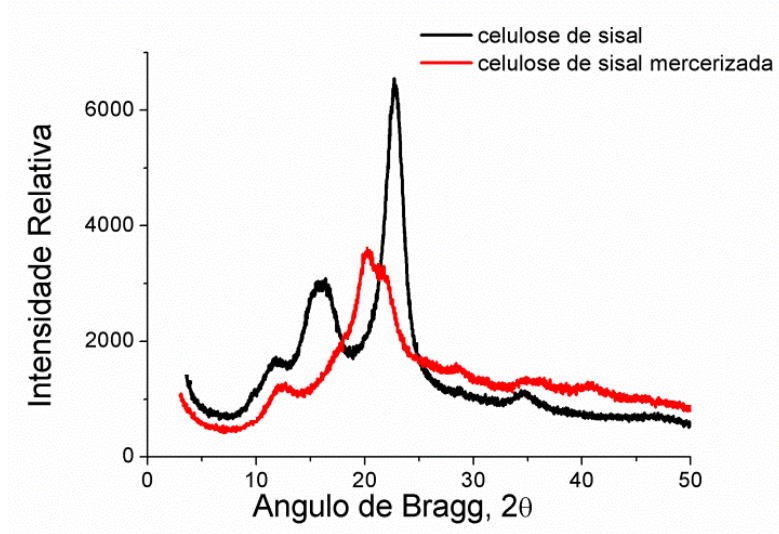

Tabela 2 - Índice de cristalinidade $\left(I_{c}\right)$ para a celulose de sisal e celulose de sisal mercerizada.

\begin{tabular}{|cc|}
\hline Amostra & $\left(\mathrm{I}_{\mathrm{c}}\right)(\%)$ \\
\hline celulose de sisal & 72 \\
celulose de sisal mercerizada & 63 \\
\hline
\end{tabular}

A análise dos dados obtidos comprova, assim como descrito na seção I.2, que o tratamento alcalino gera uma diminuição na cristalinidade da celulose, neste caso, de $\mathbf{7 2} \%$ para 63\% (Tabela 2). A penetração do $\mathrm{NaOH}$ ocorre, primeiramente, nas regiões não cristalinas da celulose, as quais são mais acessíveis, ocorrendo em seguida difusão para as regiões cristalinas, o que provoca separação de parte das cadeias. A separação de parte das cadeias é responsável pela diminuição de cristalinidade observada (MANSIKKAMÄKI; LAHTINEN; RISSANEN, 2005; RAMOS, L. A. et al., 20I I).

A diminuição da cristalinidade e o aumento de regiões não cristalinas na celulose, como consequência da mercerização, facilita 0 acesso do solvente, 0 que facilita sua 
posterior dissolução em $\mathrm{DMAc} / \mathrm{LiCl}$, assim como aumenta a acessibilidade dos grupos hidroxilas frente ao agente esterificante, nas reações realizadas em meio heterogêneo.

\subsubsection{Análise do grau de polimerização viscosimétrico e massa molar média viscosimétrica}

A partir de medidas de viscosidade, obteve-se o grau de polimerização médio viscosimétrico $\left(G P_{\text {vis }}\right)$ para as amostras de celulose de sisal antes e após mercerização, utilizando-se da Equação 2. Assim, calculou-se a massa molar média viscosimétrica $\left(M M_{v i s}\right)$ a partir de $M M_{v i s}=G P_{v i s} \times 162$, onde 162 correspondeu a massa de uma unidade de anidroglicose (UAG) (Tabela 3).

Tabela 3 - Grau de polimerização viscosimétrico médio $\left(G P_{v i s}\right)$ e massa molar média viscosimétrica $\left(M M_{v i s}\right)$ da celulose de sisal e celulose de sisal mercerizada.

\begin{tabular}{|ccc|} 
Amostra & $\boldsymbol{M M}_{\text {vis }}\left(\mathrm{g} \mathrm{mol}^{-1}\right)$ & $\left(\boldsymbol{G P}_{\text {vis }}\right)$ \\
\hline celulose de sisal & $120690 \pm 145^{*}$ & $745 \pm 5$ \\
celulose de sisal mercerizada & $110160 \pm 433$ & $680 \pm 8$ \\
\hline
\end{tabular}

* Erro considerando as diferentes medidas

Os resultados obtidos indicaram uma diminuição da massa molar média da celulose, devido ao processo de mercerização. $O$ processo de mercerização gerou a eliminação de hemiceluloses (conforme será discutido na seção seguinte), as quais, quando presentes, podem interagir com a celulose na solução de CUEN, gerando um maior volume hidrodinâmico. Com a eliminação de hemiceluloses, o volume hidrodinâmico deverá ser menor, o que por sua vez leva a uma diminuição do valor da $M M_{v i s}$ (RAMOS et al., 2005; RAMOS, L. A. et al., 20II). Por outro lado, o tratamento alcalino pode ser responsável por uma degradação parcial das cadeias celulósicas, gerando quebra de ligações glicosídicas, com consequente diminuição das massas molares médias e dos graus de polimerização das celuloses. 
No presente trabalho, a diminuição da massa molar média não foi muito significativa (Tabela 3), devido às condições brandas usadas $\left(0^{\circ} \mathrm{C}, \mathrm{I} \mathrm{h}\right.$, Experimental).

\section{I.4 Determinação do teor de $\alpha$-celulose}

O teor de $\alpha$-celulose é um indicativo do conteúdo de celulose não degradada, de maior massa molar, não contaminada pela presença de sais minerais que possam estar presentes na amostra, ou outros contaminantes. Entre outras palavras, é descrito como o conteúdo de celulose pura em uma amostra, correspondendo ao material insolúvel em solução de hidróxido de sódio 17,5\% (TAPPI, 1988).

O cálculo do teor de $\alpha$-celulose foi obtido pela diferença de massa, antes e após o tratamento da amostra com solução de $\mathrm{NaOH}$ 17,5\% (Experimental).

A Tabela 4 apresenta os valores obtidos para o conteúdo de $\alpha$-celulose nas amostras de celulose de sisal e celulose de sisal mercerizada.

Tabela 4 - Valores obtidos para a-celulose na celulose de sisal e celulose de sisal mercerizada.

\begin{tabular}{|cc|}
\hline Amostra & $\alpha$-celulose (\%) \\
\hline celulose de sisal & $83 \pm 2$ \\
\hline \hline celulose de sisal mercerizada & $9 l \pm 3$ \\
\hline
\end{tabular}

\footnotetext{
* Erro considerando as diferentes medidas
}

Observa-se um aumento significativo no conteúdo de $\alpha$-celulose na amostra mercerizada (em torno de $8 \%$ ). Isso se deve, principalmente, a uma significativa eliminação de hemiceluloses e, também, de alguns sais minerais presentes na polpa de sisal. Este fato indica a importância do tratamento da mercerização previamente às reações de derivatização. A presença de um alto teor de hemiceluloses, durante a funcionalização da celulose, pode ocasionar uma diminuição efetiva de interação celulose/reagentes, interferindo assim no grau de substituição do produto final (CIACCO et al., 20I0). 


\section{I.5 Dosagem de hemiceluloses na polpa de celulose mercerizada}

Durante o processo de mercerização da polpa celulósica, grupos ácidos, como os ácidos carboxílicos (presentes na hemicelulose), se dissociam em meio aquoso alcalino, promovendo a solubilização de hemiceluloses. A solubilização destas ocorre, principalmente, pelo rompimento de ligações hidrogênio. No geral, todas as ligações do tipo éster, presentes na estrutura da hemicelulose, podem ser hidrolisadas pela ação do álcali, aumentando o caráter hidrofílico e, consequentemente, a solubilidade dos produtos de hidrólise (XIAO; SUN; SUN, 200I; SUN; SUN, 2002). Além disso, como abordado na Seção 3.I.2, a depender das condições utilizadas (tempo, temperatura, presença de oxigênio), a mercerização pode levar também a degradação parcial das cadeias celulósicas, gerando quebra de ligações glicosídicas.

A hidrólise ácida, com $\mathrm{H}_{2} \mathrm{SO}_{4}$, feita previamente à análise via HPLC, gera uma despolimerização do polissacarídeo, formando oligômeros e seus açúcares constituintes, isto é, suas unidades repetitivas. No caso da hemicelulose, as maiores frações são de xilose, galactose (em menores quantidades) e pequenas proporções de arabinose, glicose, manose. Já para a celulose, são formados glicose, majoritariamente (como produto de hidrólise) e hidroximetilfurfural (HMF) como produto de decomposição, que, por sua vez, pode ser convertido a ácido fórmico (PALMQVIST; HAHN-HÄGERDAL, 2000; DE PAULA et al., 2012; LACERDA; ZAMBON; FROLLINI, 20I3).

O rendimento total calculado para a hidrólise da polpa de sisal mercerizada, em termos de xilose, glicose e produtos de decomposição obtidos (furfural e HMF), é representado na Figura 21 . 
Figura 2l - Teores de xilose/furfural e glicose/HMF advindos da hidrólise da polpa de celulose de sisal mercerizada.

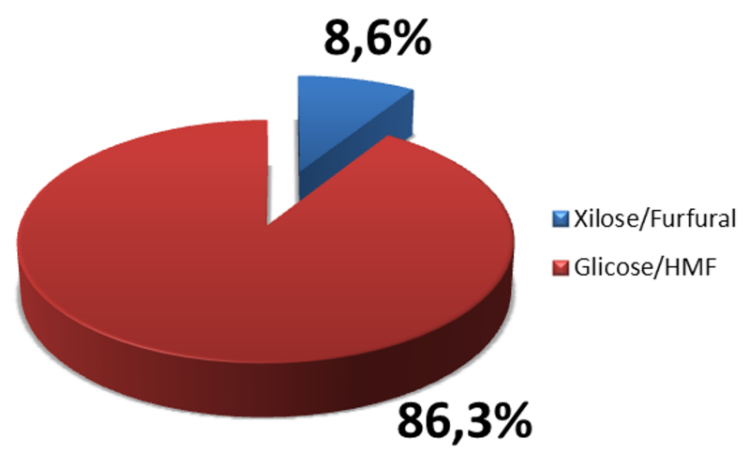

É observado que o balanço de massa total da hidrólise foi próximo a $95 \%$ e sabe-se que o conteúdo de cinzas do sisal é de aproximadamente $1 \%$. O restante, provavelmente, correspondeu a açúcares não analisados e/ou frações oligoméricas da celulose, os quais não hidrolisaram até glicose.

Após hidrólise, identificou-se apenas presença de glicose, xilose, HMF e furfural na amostra hidrolisada, sendo este último um produto de decomposição da hemicelulose. A presença de xilose, como único monossacarídeo detectado, advindo da hidrólise de hemiceluloses, sugere uma alta presença de xilanas, as quais correspondem aos principais açúcares encontrados nas paredes celulares das plantas, não oriundas da madeira, constituindo mais de $30 \%$ da massa seca destas (SUN et al., 2004; MEGIATTO et al., 2007).

A concentração de xilose encontrada, após hidrólise, foi de $0,14 \mathrm{~g} \mathrm{~L}^{-1}$. Sabendo que a xilose corresponde a cerca de 68,5\% da hemicelulose total (MEGIATTO et al., 2007), e que $0,14 \mathrm{~g} \mathrm{~L}^{-1}$ corresponde a um total de $0,08 \mathrm{~g}$ de xiloses na solução final $(575 \mathrm{~mL})$, seria de se esperar uma massa total de hemiceluloses de 0,12 g. Essa massa de hemiceluloses corresponderia a $12,4 \%$ do total da massa seca de polpa de celulose inicial $(0,9520 \mathrm{~g})$. valor encontrado para hemiceluloses na polpa de celulose de sisal mercerizada, pela análise de $\alpha$-celulose, foi de $9 \%$, considerando-se que todo o conteúdo solúvel em solução de $\mathrm{NaOH}$ 17,5\% correspondeu apenas a essas polioses (Tabela 4). Esse valor é menor que o encontrado via análise de HPLC. Apesar de que os erros experimentais relacionados às análises devem ser considerados, este resultado pode ser também um indicativo de que, na análise de $\alpha$-celulose, frações de hemiceluloses não hidrolisadas remanesceram. Esses teores de hemiceluloses encontrados pela análise de HPLC e $\alpha$-celulose são menores do que o teor 
de hemicelulose normalmente encontrado na fibra lignocelulósica de sisal, de 19,5\% (MEGIATTO et al., 2007). Ressalta-se, entretanto, que as hemiceluloses presentes nas fibras lignocelulósicas também podem ser parcialmente eliminadas nos processos de polpação, as quais utilizam tratamentos alcalinos visando à remoção da lignina. No caso da polpa celulósica de sisal utilizada neste trabalho, o processo Kraft, o qual envolveu tratamento com hidróxido de sódio $(\mathrm{NaOH})$ e sulfeto de sódio $\left(\mathrm{Na}_{2} \mathrm{~S}\right)$, pode ter sido responsável pela remoção parcial das hemiceluloses presentes nas fibras lignocelulósicas de sisal de partida.

Portanto, é justificado o uso da celulose de sisal mercerizada como material de partida nas reações de derivatização da celulose, a qual apresenta indubitavelmente um menor teor de hemiceluloses.

\section{I.6 Microscopia eletrônica de varredura (MEV)}

As morfologias da celulose de sisal e celulose de sisal mercerizada foram avaliadas por MEV. A Figura 22 apresenta as imagens obtidas para as amostras, em diferentes ampliações.

Figura 22 - Fotomicrografias da celulose de sisal ampliada (a) 1000x e (b) 10.000; celulose de sisal mercerizada ampliada (c) 1000x e (d) 5.000x.
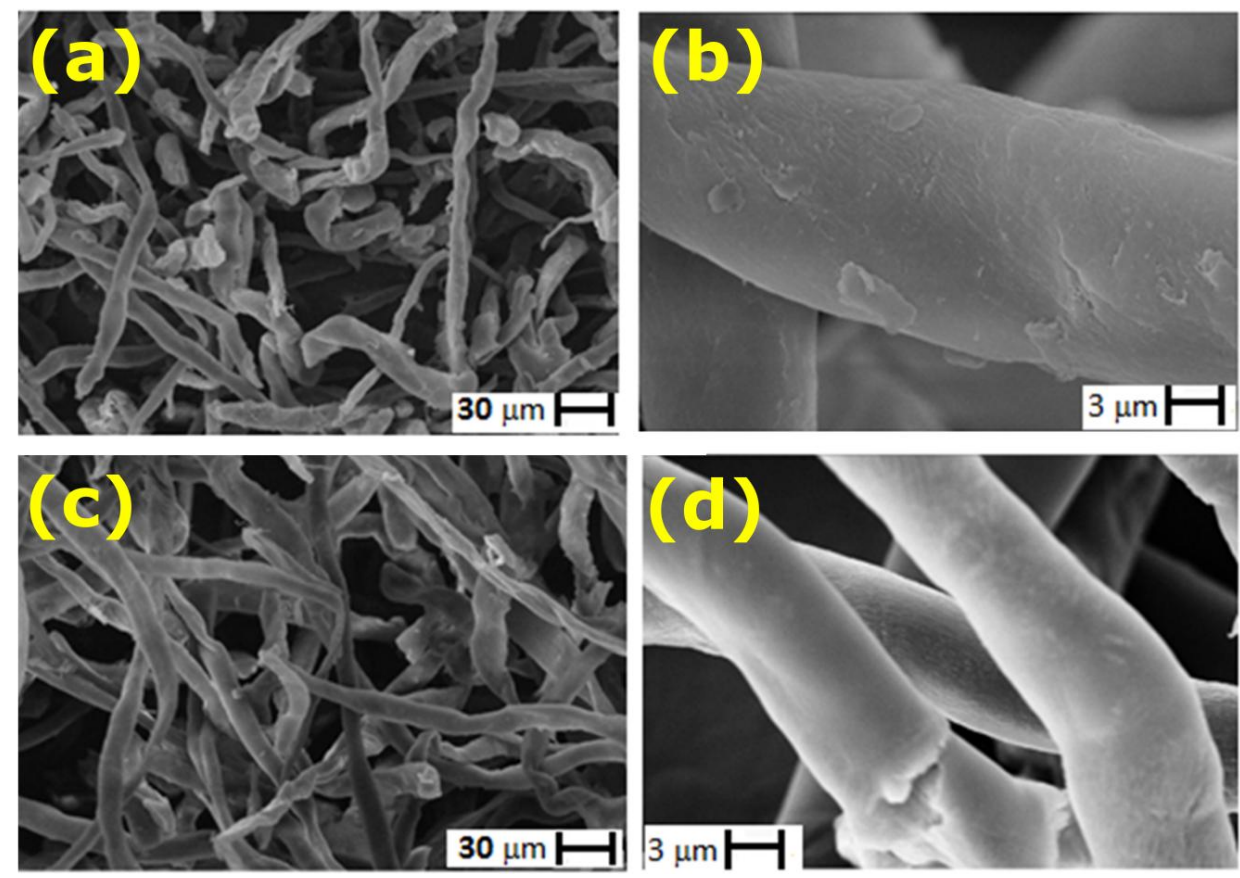
Observa-se que não houve significativas mudanças nas fibras de celulose de sisal, em termos de espessura, sendo que para ambas um valor de 8-12 $\mu \mathrm{m}$ foi observado.

Quanto ao aspecto da superfície da fibra, para a celulose de sisal mercerizada [Figuras 22-(c) e (d)] este é mais liso em relação à superfície da celulose de sisal não tratada [Figuras 22-(a) e (b)]. Isso é comprovado pela menor presença de fragmentos aderidos às fibras, como se pode observar comparando as Figuras 22-(b) e (d).

\section{I.7 Análise Termogravimétrica}

A compreensão do comportamento da decomposição térmica da celulose é fundamental para a conversão termoquímica da biomassa (SHEN; GU, 2009; CHEN et al., 2014). No presente trabalho, as estabilidades térmicas da celulose de sisal e da celulose de sisal mercerizada foram investigadas por meio da análise termogravimétrica (TG).

A Figura 23 apresenta as curvas das análises termogravimétricas das fibras de celulose de sisal e celulose de sisal mercerizada.

Figura 23 - Curva TG da celulose de sisal (a) e celulose de sisal mercerizada (b), com respectiva $1^{\circ}$ derivada (dTG) (atmosfera de $\mathrm{N}_{2}$, razão de aquecimento de $20^{\circ} \mathrm{C} \mathrm{min}^{-1}$ ).
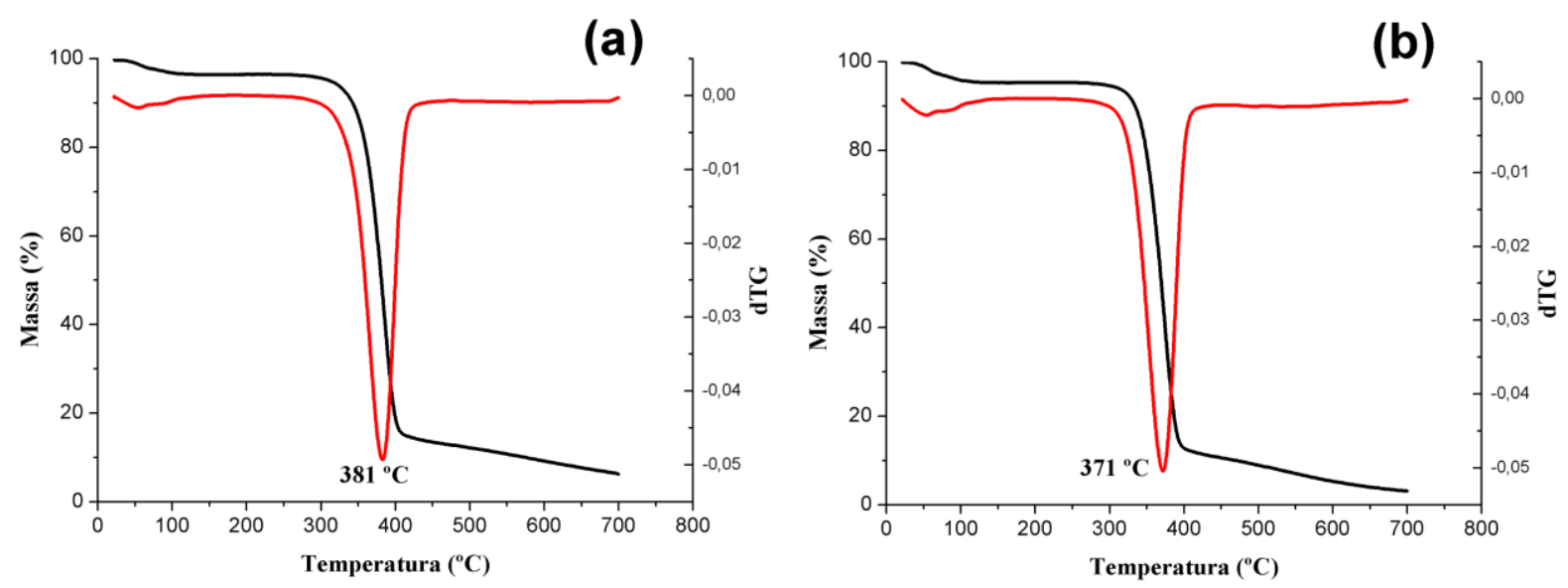

De acordo com as curvas obtidas nas análises termogravimétricas das celuloses, em atmosfera de nitrogênio, dois principais estágios de perda de massa podem ser atribuídos. primeiro estágio, no intervalo de aproximadamente $25-110^{\circ} \mathrm{C}$, é atribuído à perda de 
umidade adsorvida/absorvida. $\mathrm{O}$ segundo estágio, com início em cerca de $280^{\circ} \mathrm{C}$ e término em torno de $430^{\circ} \mathrm{C}$, é atribuído ao processo de decomposição principal (FLAQUÉ; MONTSERRAT, 1999). O primeiro estágio corresponde ao fenômeno de desidratação física da celulose (FLAQUÉ; MONTSERRAT, 1999). A celulose, devido a sua estrutura e natureza polar, contém umidade adsorvida, ou absorvida, sendo que a maior parte desta, quando submetida a um aquecimento lento, é liberada.

$\mathrm{Na}$ Tabela 5 são encontradas as descrições dos parâmetros obtidos a partir das análises das curvas de TG.

Tabela 5 - Dados da decomposição térmica da celulose de sisal e celulose de sisal mercerizada obtidos via análises termogravimétricas.

\begin{tabular}{|c|c|c|c|c|c|}
\hline Amostra & $\begin{array}{c}\text { Perda de massa } I^{\circ} \\
\text { estágio }\left(25-110^{\circ} \mathrm{C}\right) \\
(\%)\end{array}$ & $\mathrm{T}_{\mathrm{i}}\left({ }^{\circ} \mathrm{C}\right)$ & $\mathrm{T}_{\mathrm{f}}\left({ }^{\circ} \mathrm{C}\right)$ & $\begin{array}{c}\text { Perda de massa } 2^{\circ} \\
\text { estágio }\left(T_{i} \text { até } T_{f}\right) \\
(\%)\end{array}$ & $\mathrm{T}_{\mathrm{p}}\left({ }^{\circ} \mathrm{C}\right)$ \\
\hline cel. de sisal & 3,4 & 272 & 442 & 83 & 381 \\
\hline $\begin{array}{l}\text { cel. de sisal } \\
\text { mercerizada }\end{array}$ & 4,4 & 283 & 424 & 83 & 371 \\
\hline
\end{tabular}

Por meio dos dados obtidos, observa-se que para a perda de massa no $\mathrm{I}^{\circ}$ estágio, a massa de água absorvida (ou adsorvida) foi maior para a celulose de sisal mercerizada. Isso comprova o diferente caráter higroscópico das regiões não cristalinas e cristalinas da celulose, sendo que a celulose mercerizada, que possui menor cristalinidade (Tabela 2), absorve água mais facilmente (FENGEL; WEGENER, 1983). Por consequência, a perda de água absorvida envolve principalmente as regiões não cristalinas da celulose (ASS; FROLLINI; HEINZE, 2004).

O segundo estágio corresponde à decomposição térmica da celulose, a qual ocorre acima de $280^{\circ} \mathrm{C}$. A primeira reação de decomposição da celulose envolve desidratação e leva a formação de anidroglicose, a qual pode ser resultado de desidratação intra e inter anéis. A termólise da celulose ocorre pela quebra de ligações glicosídicas, ligações $\mathrm{C}-\mathrm{H}, \mathrm{C}-\mathrm{O}$ e C-C, assim como pela descarbonilação, descarboxilação e a desidratação comentada anteriormente. Estes processos revelam a importância do grupo hidroxila em C6 no processo de decomposição da celulose (Figura 24), o qual é envolvido nas reações que levam a levoglucosana (Figura 25), produzida pela transglicosilação via reações intramoleculares (SCHEIRS; CAMINO; TUMIATTI, 200I; ZHANG et al., 20II), sendo este o produto mais 
abundante (SCHEIRS; CAMINO; TUMIATTI, 200I; ZHANG et al., 20II). Além de levoglucosana, outros produtos secundários também são gerados, entre eles, anidroglicoses (I,2-I,4-anidriglicose, I,6-anidroglicofuranose e enonas), furano derivados furânicos. Assim, os picos de decomposição observados via análise TG, provavelmente, correspondem a esses processos (Figura 23).

Figura 24 - Reações de eliminação de água na celulose durante a decomposição térmica (SCHEIRS; CAMINO; TUMIATTI, 200I).
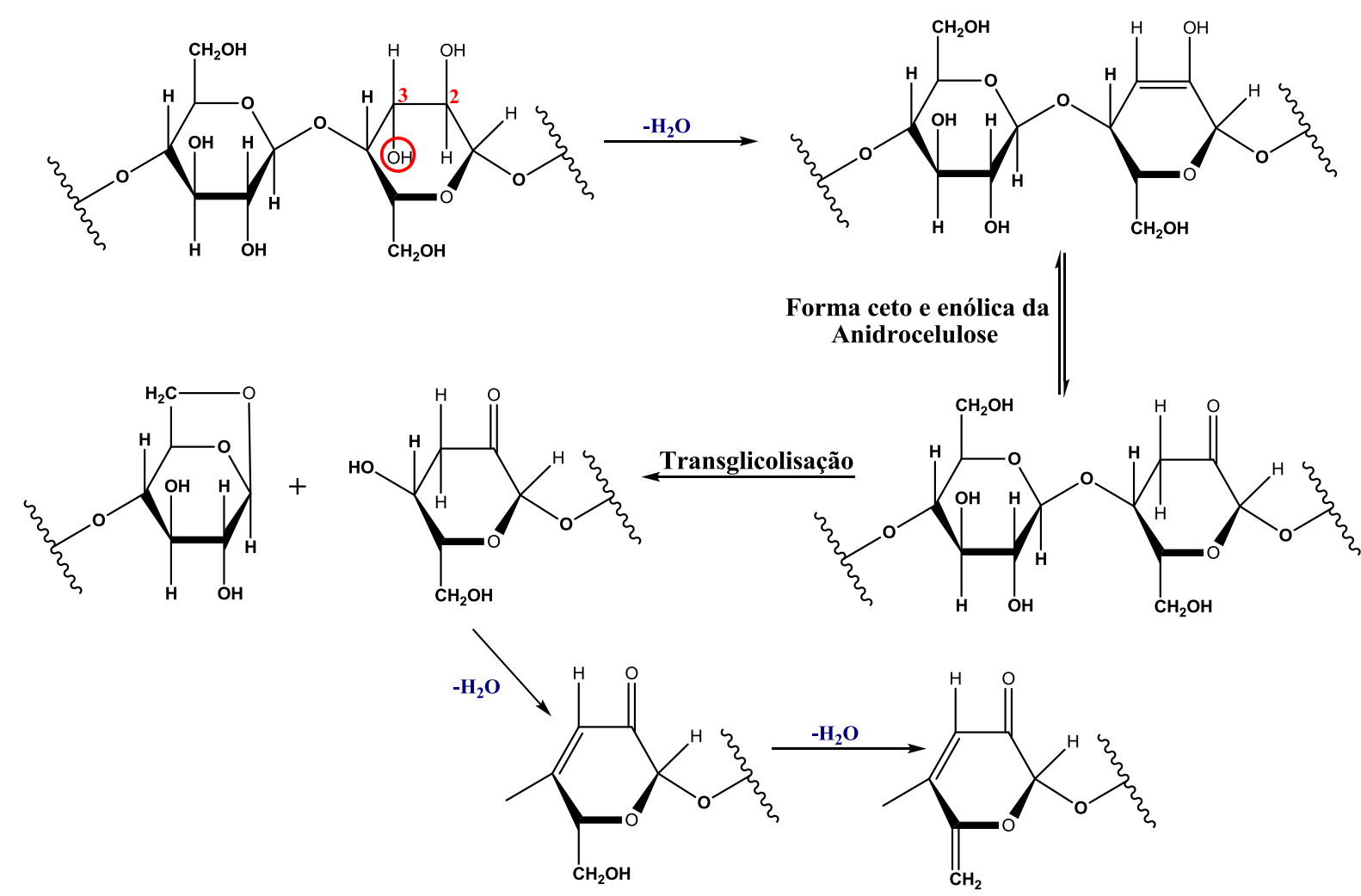

Figura 25 - Estrutura da levoglucosana.

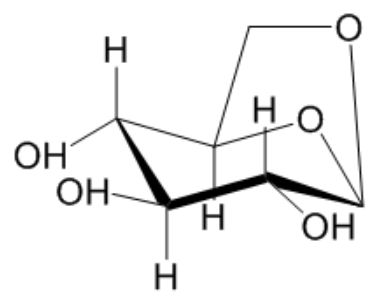

A temperatura na qual a taxa de decomposição alcança um valor máximo, $T_{p}$, indicada no pico das curvas dTG (Figura 23), foi menor para a celulose de sisal mercerizada. Nas regiões cristalinas, as ligações hidrogênio entre as cadeias são mais fortes que aquelas nas regiões não cristalinas e necessitam maior energia durante o processo de decomposição. 
Assim, a maior proporção de domínios cristalinos provavelmente levou a um maior valor de $\mathrm{T}_{\mathrm{p}}$ para a celulose de sisal em relação à celulose de sisal mercerizada, a qual apresenta menor cristalinidade (Tabela 2). A região não cristalina da celulose é mais ativamente decomposta que a região cristalina, adicionando maiores complexidades no processo de decomposição (WIEDERSCHAIN, 2007; MORGADO; FROLLINI, 20I I).

\section{2 Ésteres de celulose de sisal obtidos em meio homogêneo}

A celulose de sisal mercerizada e devidamente caracterizada, como previamente descrito, foi usada como material de partida na preparação de ésteres de celulose de sisal com diferentes tamanhos de cadeias e grau de substituição. Nesta seção, os resultados obtidos para as reações realizadas em meio homogêneo, utilizando DMAc/LiCl com sistema de solvente, serão apresentados. $\mathrm{Na}$ seção a seguir (Seção 3.3), serão apresentados os resultados obtidos para as reações realizadas em meio heterogêneo.

\subsection{Grau de Substituição (GS)}

Como já discutido anteriormente, o grau de substituição (GS) é um indicativo do número médio de substituintes por unidade de anidroglicose (UAG). Pode-se calcular o GS por meio da relação entre a área correspondente à ressonância dos átomos de hidrogênio do anel de glicose $(\delta \sim 2,90-5,10$ ppm) e a área correspondente à ressonância dos átomos de hidrogênio do grupo metila do da cadeia éster correspondente ( $\delta \sim 1,70-2,20$ ppm), por meio da Equação 3. É importante ressaltar que o resultado de GS obtido difere-se do GS estequiométrico, isto é, do GS esperado por meio da razão do número de mol do agente esterificante usado e de celulose (unidade anidroglicosídica, UAG) no meio reacional $\left(\mathrm{Mol}_{\text {Anidrido }} / \mathrm{Mol}_{\mathrm{UAG}}\right)$. Conforme será melhor discutido no Capítulo 2 (Seção I.I), a possível agregação das cadeias celulósicas no meio em que esta é dissolvida, a qual consiste em um 
processos irreversível e que leva a agregados de alta massa molar, é um grande responsável pela dificuldade na acessibilidade dos reagentes em reações de modificação química. Assim, visto que o agente esterificante não reage em sua totalidade no curso da reação e também visto a grande influência da estrutura supramolecular da celulose durante a dissolução, não é possível a obtenção do GS estequiométrico. Consequentemente, excessos de reagentes são usados, isto é, $\mathrm{Mol}_{\text {Anidrido }} / \mathrm{Mol}_{\mathrm{UAG}}>3$, visando à obtenção de derivados com GS superiores.

Nas Figuras 26-28 são apresentados espectros de 'H RMN obtidos para diferentes ésteres de celulose, usando como sistema de solvente o $\mathrm{DMAc} / \mathrm{LiCl}$.

Figura 26 - Espectro de RMN-'H para um acetato de celulose obtido a partir de celulose de sisal mercerizada, com as áreas de integração delimitadas.

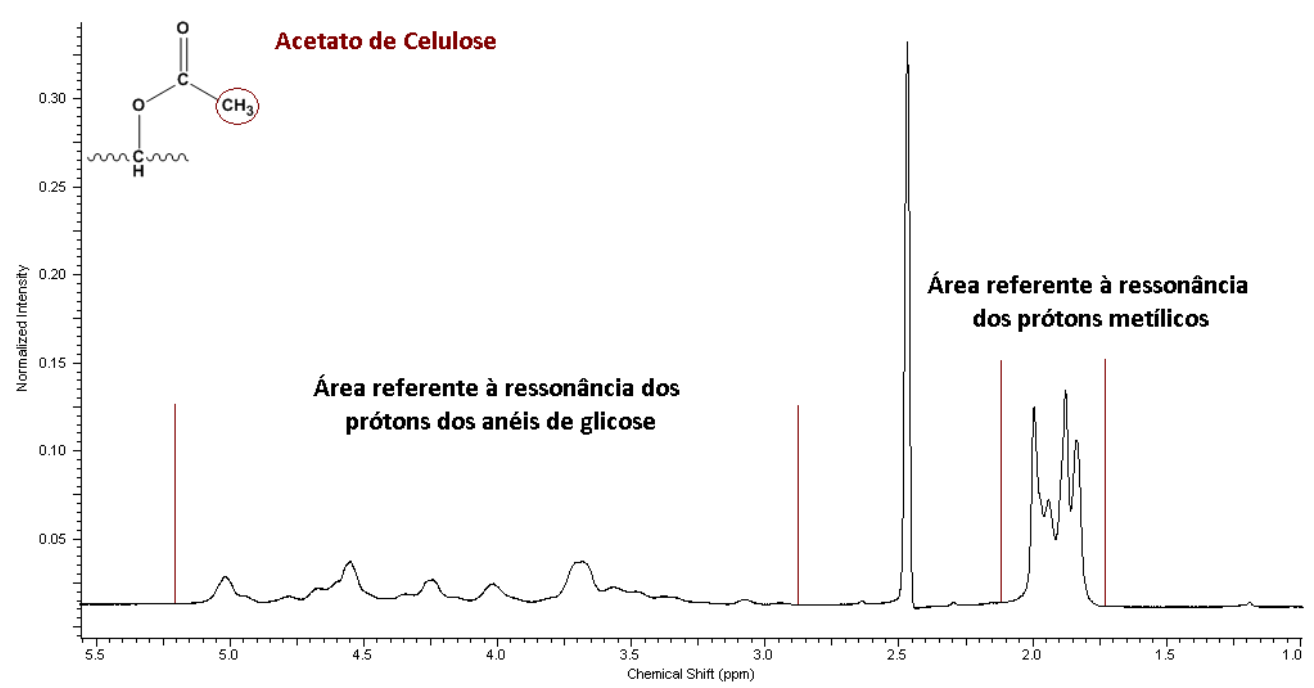


Figura 27 - Espectro de RMN-'H para um butanoato de celulose obtido a partir de celulose de sisal mercerizada, com as áreas de integração delimitadas.

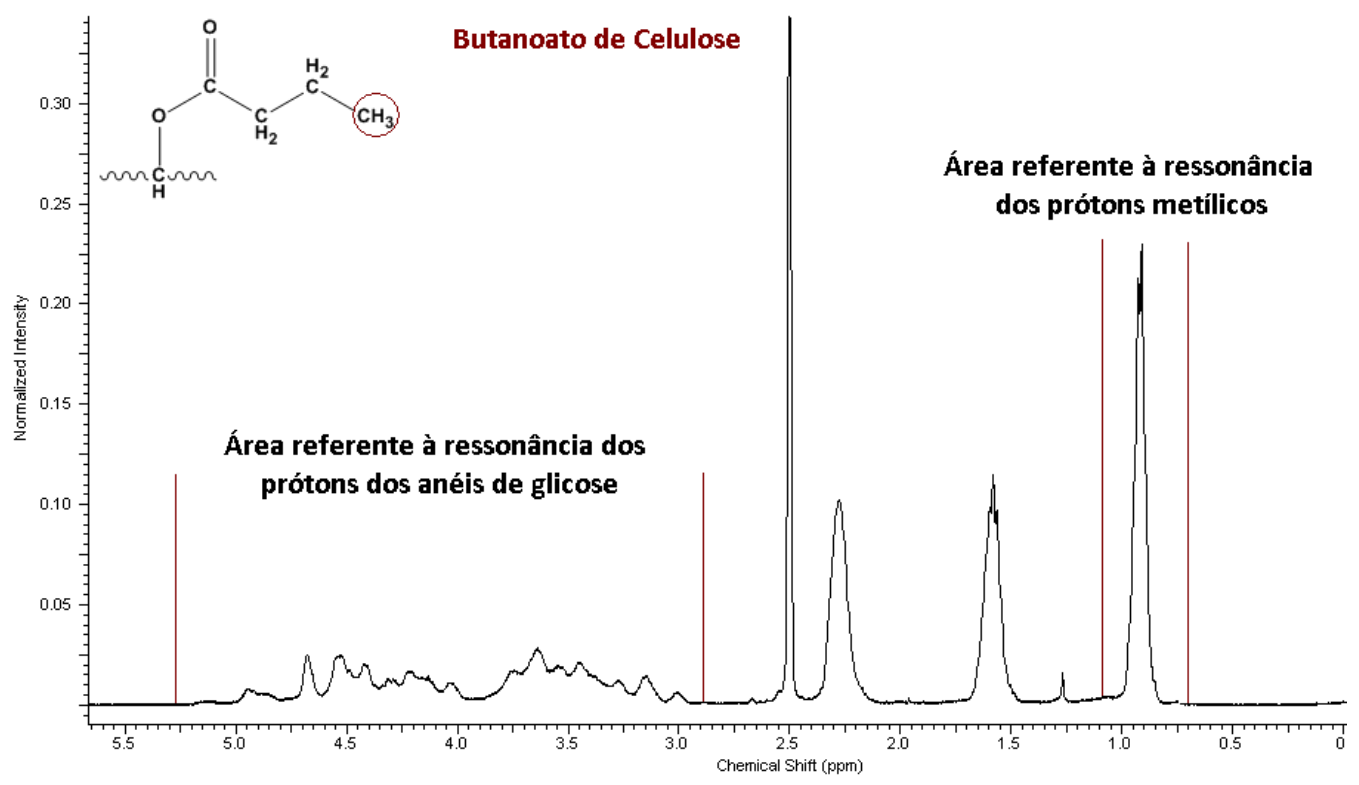

Figura 28 - Espectro de RMN-'H para um hexanoato de celulose obtido a partir de celulose de sisal mercerizada, com as áreas de integração delimitadas.

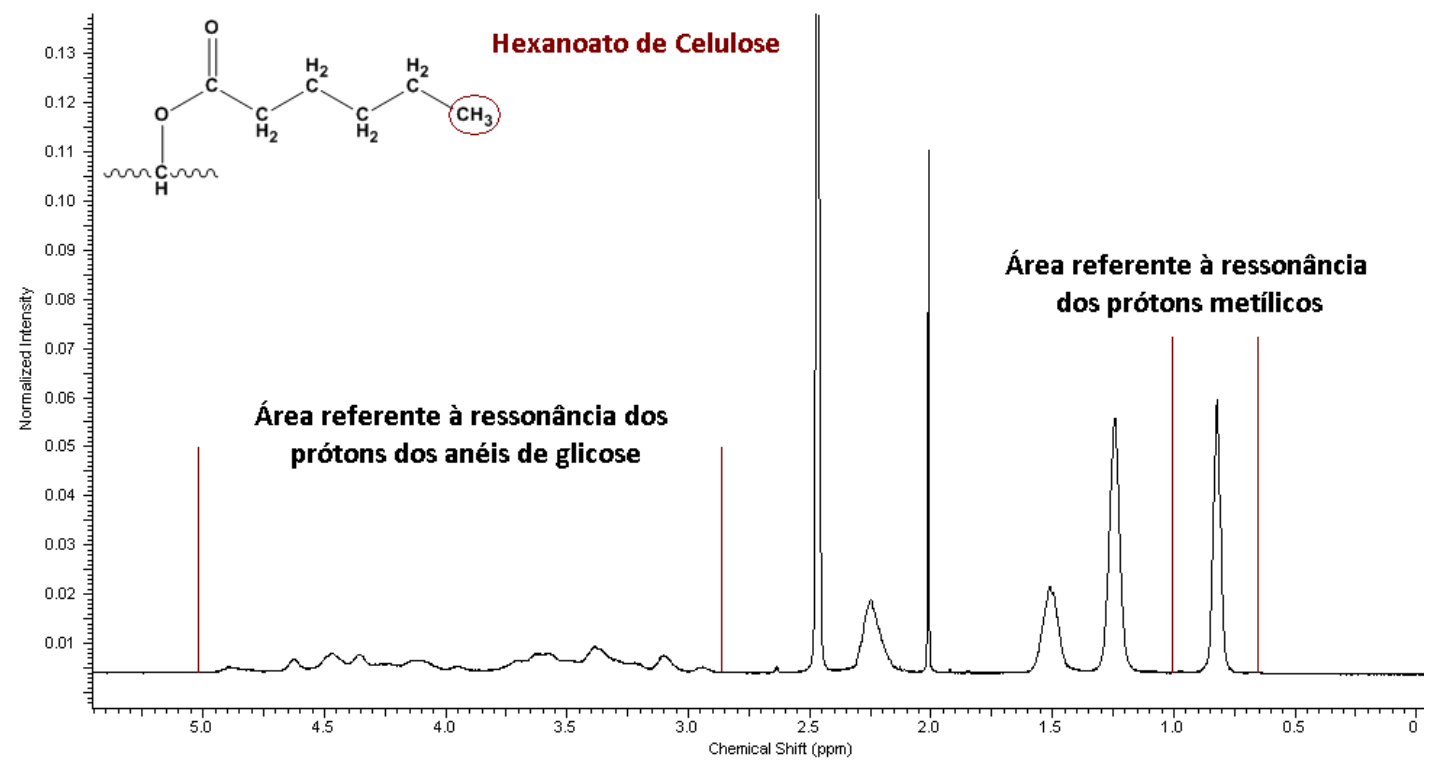

$\mathrm{Na}$ Tabela 6 são descritos os resultados de grau de substituição para os diferentes ésteres de celulose de sisal, obtidos no sistema de solvente DMAc/LiCl. 
Tabela 6 - Grau de substituição para os diferentes ésteres de celulose de sisal preparados em meio homogêneo (DMAc/LiCl).

\begin{tabular}{|c|c|c|c|c|}
\hline Éster & $\begin{array}{l}\text { Tempo } \\
\text { (h) }\end{array}$ & $\begin{array}{c}\text { Razão molar } \\
\text { Anidrido/mol UAG }\end{array}$ & $\begin{array}{c}\text { GS } \\
\text { estequiométrico* }\end{array}$ & GS obtido \\
\hline \multirow{5}{*}{$\begin{array}{l}\text { Acetato de } \\
\text { Celulose }\end{array}$} & \multirow{5}{*}{4} & 1,5 & $\mathrm{I}, 5$ & 0,7 \\
\hline & & 3,0 & 3,0 & 1,3 \\
\hline & & 6,0 (excesso) & 3,0 & 1,8 \\
\hline & & 9,0 (excesso) & 3,0 & 2,5 \\
\hline & & I2,0 (excesso) & 3,0 & 3,0 \\
\hline \multirow{6}{*}{$\begin{array}{l}\text { Butanoato } \\
\text { de Celulose }\end{array}$} & \multirow{5}{*}{4} & 1,5 & 1,5 & 0,7 \\
\hline & & 3,0 & 3,0 & 1,3 \\
\hline & & 6,0 (excesso) & 3,0 & 1,8 \\
\hline & & 9,0 (excesso) & & 2,2 \\
\hline & & I2,0 (excesso) & 3,0 & 2,6 \\
\hline & 12 & I2,0 (excesso) & 3,0 & 3,0 \\
\hline \multirow{6}{*}{$\begin{array}{l}\text { Hexanoato } \\
\text { de Celulose }\end{array}$} & \multirow{6}{*}{4} & 1,5 & 1,5 & 0,2 \\
\hline & & 2,5 & 2,5 & 0,7 \\
\hline & & 3,0 & 3,0 & 0,9 \\
\hline & & 6,0 (excesso) & 3,0 & 1,8 \\
\hline & & 9,0 (excesso) & 3,0 & 2,2 \\
\hline & & 12,0 (excesso) & 3,0 & 2,7 \\
\hline
\end{tabular}

* calculado por meio da razão Mol Anidrido $_{\text {Mol UAG }}$ (ver seção 2.3.I.2)

Na Tabela 6 são mostrados os resultados de GS obtidos e os esperados de acordo com a estequiometria da reação (GS estequiométricos). Como previamente abordado, visto a impossibilidade de obtenção de GS estequiométrico, excessos de agentes esterificantes foram usados $\left(\mathrm{Mol}_{\text {Anidrido }} / \mathrm{Mol}_{\mathrm{UAG}}>3\right.$ ) visando à obtenção ésteres com diferentes GS. Na Figura 29 são apresentadas as curvas da dependência do grau de substituição com a razão $\mathrm{Mol}_{\text {Anidrido }} / \mathrm{Mol}_{\text {UAG }}$ para os diferentes ésteres de sisal obtidos em meio homogêneo, utilizando o sistema de solvente DMAc/LiCl (4 h de reação). 
Figura 29 - Dependência do grau de substituição com a razão Mol $_{\text {Anidrido }} /$ Mol UAG para os ésteres de sisal obtidos em meio homogêneo (4 h de reação).

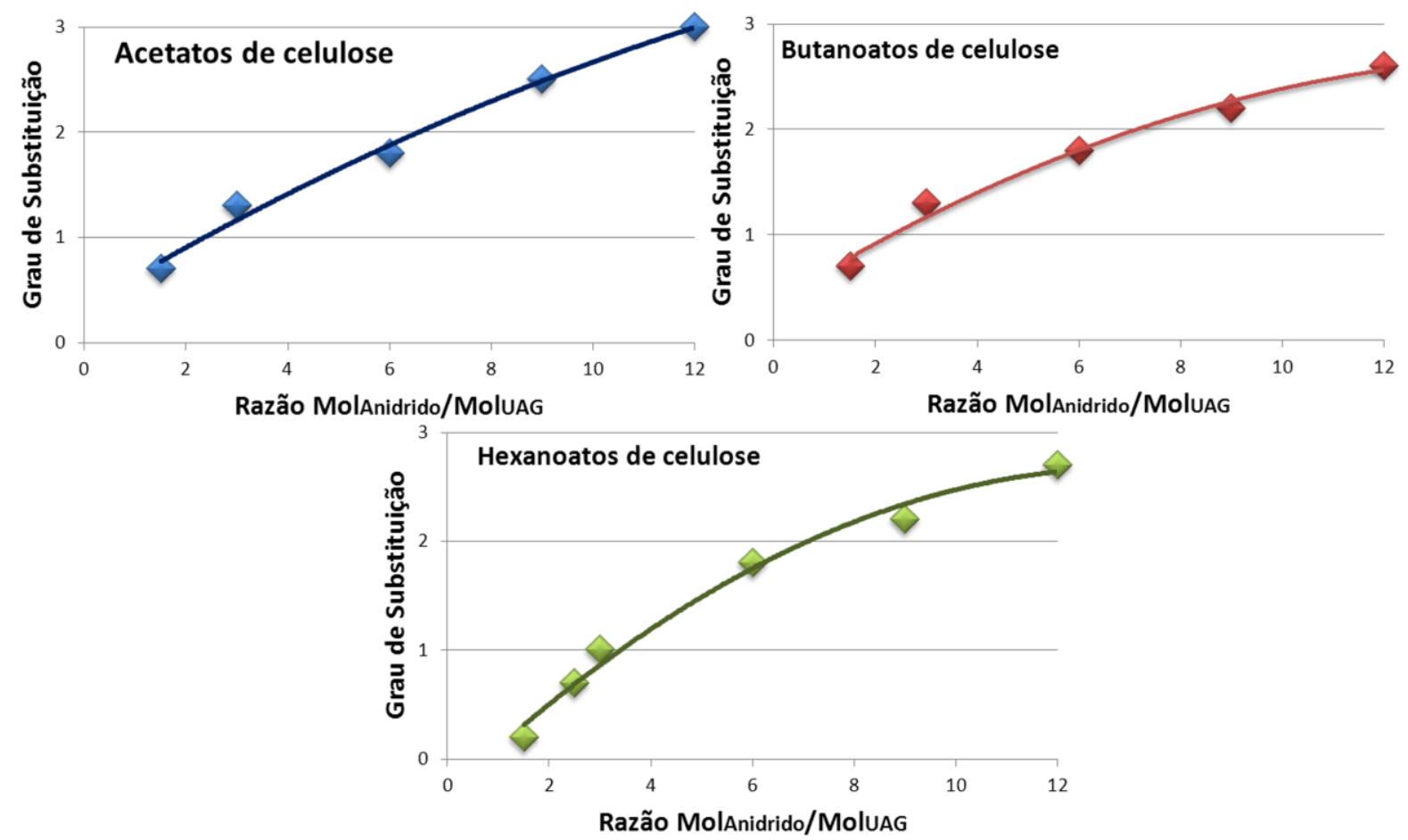

Para todos os ésteres, nota-se que com o aumento da razão $\mathrm{Mol}_{\text {Anidrido }} / \mathrm{Mol}_{\text {UAG }}$ ocorre também o aumento do grau de substituição do éster (Tabela 6, Figura 29), assim como esperado. Para os butanoatos de celulose, o uso de maiores intervalos de tempo, considerando a mesma razão $\mathrm{Mol}_{\text {Anidrido }} / \mathrm{Mol}_{\mathrm{UAG}}$, levou a produtos com GS maiores (Tabela 6, 12 h e 18 h de reação). Sendo assim, tornou-se importante investigar o impacto de maiores tempos de reações para anidridos de maiores cadeias, visando avaliar a possibilidade de obtenção de maiores GS, com ○ uso de menor quantidade de agente esterificante. Entretanto, o consumo de energia nessas reações seria muito maior, o que haveria de ser ponderado e estudado para uma série de reações em que tempo/consumo de reagentes fossem avaliados.

Pode ser observado que quanto maior a cadeia do anidrido, mais lentamente este reagiu com a celulose. Isso pode ser provavelmente justificado pelo efeito estérico, ou seja, pela dificuldade de aproximação do agente acilante aos sítios reativos da celulose. Portanto, foram obtidos menores GS, nas mesmas condições, para os hexanoatos de celulose, quando comparado aos acetatos e butanoatos de celulose. Até uma razão $\mathrm{Mol}_{\text {Anidrido }} / \mathrm{Mol}$ UAG de 3,0 para hexanoatos de celulose, são encontrados baixos valores de GS $(0,9)$, quando 
comparados para a mesma razão utilizada para os acetatos de celulose e butanoatos de celulose $(\mathrm{GS}=1,3)$. Entretanto, em razões maiores, como 6,0, tem-se um aumento consideravelmente maior para os hexanoatos (GS I,8) (Tabela 6). Isso pode ser explicado, possivelmente, pelo fato que ao se iniciar a acilação, com anidridos de maiores cadeias, a celulose, antes agregada, é submetida a uma maior separação entre suas cadeias (devido à entrada de grupos acilas com grandes cadeias carbônicas), o que favorece a aproximação de novas cadeias do agente esterificante. Adicionalmente, pode-se considerar as interações hidrofóbicas entre esses anidridos de maiores cadeias e a superfície da celulose, a qual sofreu um aumento do caráter hidrofóbico devido a acilação parcial, favorecendo a posterior acilação devido às interações entre as regiões de baixa polaridade da cadeia e do reagente, que tende então a intensificar a aproximação aos sítios reativos (POSSIDONIO; FIDALE; EL SEOUD, 20I0; CASARANO et al., 20II).

\subsubsection{Difração de raios $X$}

Nesta etapa, foram obtidos os difratogramas de raios $X$ para os ésteres de celulose preparados em meio homogêneo. Para os acetatos de celulose, os difratogramas de raios $X$ revelaram padrões cristalográficos típicos daqueles observados para as amostras de celulose II (celulose mercerizada). A Figura $\mathbf{3 0}$ compara os difratogramas obtidos para um acetato de celulose de sisal (GS 2,9) e para a celulose de sisal mercerizada. 
Figura 30 - Difratograma de raios $X$ da celulose de sisal mercerizada e acetato de celulose de sisal (GS 2,9).

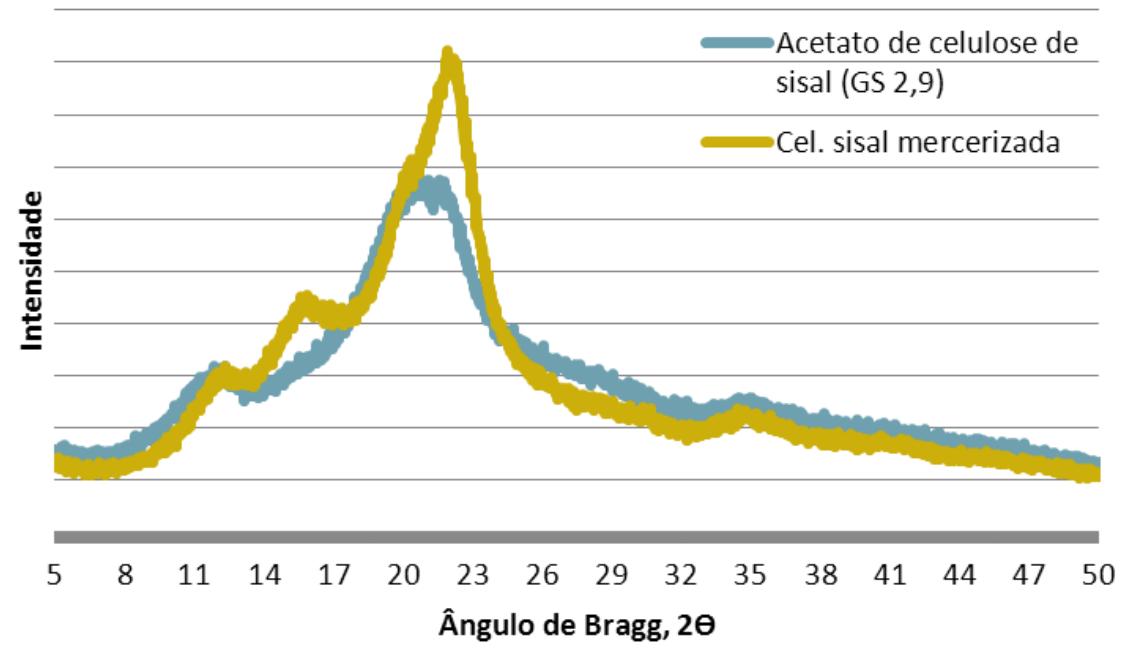

Entretanto, para os ésteres de celulose de cadeias mais longas que o acetato, observou-se um perfil de raios $X$ diferente daquele observado para a celulose e seus derivados acetatos (Figura $3 \mathrm{I}$ ).

Figura 3 I - Difratograma de raios $X$ para a celulose mercerizada e seus ésteres de cadeia longa.

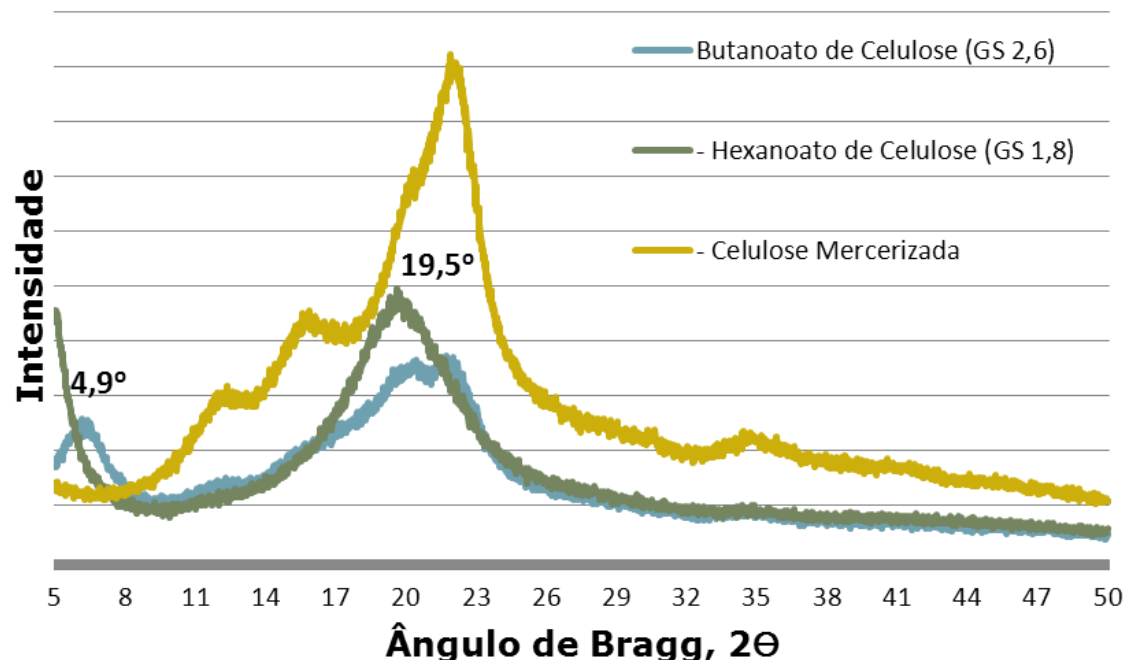

Observa-se que, para os ésteres de cadeias mais longas (Figura 3I), a intensidade dos 4 picos $\left(2 \theta=12,7^{\circ}, 16,4^{\circ}, 22,8^{\circ}\right.$ e $\left.34^{\circ} 7\right)$ diminuem em relação ao difratograma da celulose, e picos na região de $2 \theta \sim 4,9^{\circ}$ são observados. 
Okamura et al. (1983) observou em um estudo cristalográfico de uma série homóloga de ésteres de celulose $(\mathrm{C} 2-\mathrm{Cl} 2)$ que, com o aumento do número de carbonos da cadeia, o primeiro pico (em $2 \theta=4,9^{\circ}$ ) se desloca para regiões de menores ângulos. A Figura 31 ilustra este deslocamento, onde pode se observado que $\circ$ pico em $2 \theta=4,9^{\circ}$ para 0 hexanoato de celulose está deslocado para regiões de menores ângulos em relação ao butanoato de celulose. Uma vez que este pico está relacionado com o espaço interplanar (Equação 4), pode ser observado que com o aumento da cadeia do éster (e consequente diminuição de $\theta$ ) ocorre também o aumento do espaço interplanar.

$$
\text { Espaço Interplanar }=\frac{n \lambda}{\sin \theta} \quad \text { [Eq. 4] }
$$

Sendo $\mathrm{n}=\mathrm{I}, \lambda$ é igual ao comprimento de onda da radiação utilizada $(\mathrm{Cu}, 0,15406 \mathrm{~nm})$ e $\theta$ é igual ao ângulo de difração de Bragg ( ${ }^{\circ}$ ),

Uma vez que o espaço interplanar pode ser assumido como a distância entre duas cadeias de ésteres vizinhas, observa-se que o aumento da cadeia gerou, como esperado, um maior afastamento entre as mesmas. Estes resultados estão em consonância com estudos reportados anteriormente (OKAMURA; NORIMOTO; SHIRAISHI, I983; MATSUMURA; SUGIYAMA; GLASSER, 2000).

A Figura 32 apresenta os difratogramas obtidos para os butanoatos de celulose com diferentes GS. 
Figura 32 - Difratograma de raios $X$ para os butanoatos de celulose obtidos em meio homogêneo.

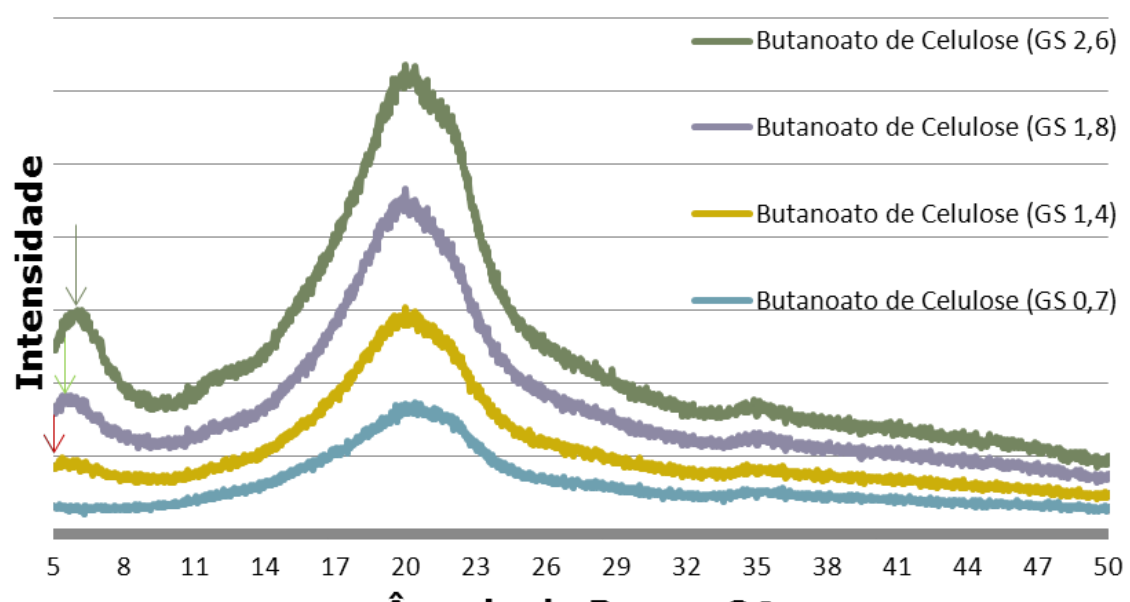

Ângulo de Bragg, $2 \theta$

Pode-se observar, a partir dos difratogramas dos butanoatos de celulose, que o primeiro pico (Figura 32) se deslocou para $2 \theta$ entre $5-7^{\circ}$, com o aumento do GS. Aplicandose a equação de distância interplanar (Equação 4), nota-que para os três butanoatos de maiores GS $(I, 4 ; 1,8$ e 2,6) tem-se distâncias interplanares de valores iguais a I,58 nm, I,53 $\mathrm{nm}$ e I,43 nm, respectivamente. Destaca-se que este primeiro pico não foi encontrado no difratograma do butanoato de GS 0,7 , com inicio em $2 \theta=3^{\circ}$, o que sugere que o pico estaria abaixo de $3^{\circ}$, o que levaria a uma distância interplanar maior que I,58 nm, encontrada para o butanoato de GS I,4.

A diminuição da distância interplanar, com o aumento do GS, provavelmente é consequência do fato que, com a gradual introdução de grupos ésteres de cadeia longa na cadeia da celulose, as interações hidrofóbicas intermoleculares entre as cadeias vizinhas passam a ser cada vez mais intensas, gerando maior aproximação entre estas cadeias. Adicionalmente, nos grupos butanoatos pode ocorrer rotação em torno da ligação $\mathrm{C}_{\mathrm{sp} 3}-\mathrm{C}_{\mathrm{sp} 3}$, gerando diferentes conformações, inclusive aquelas que podem ocupar menor volume. Em GS menores se tem ainda muitas hidroxilas livres, e as cadeias laterais alifáticas podem assumir conformações mais estendidas, pois é alta a probabilidade da presença de hidroxilas (pequeno volume) nas cadeias celulósicas vizinhas. Por outro lado, em GS superiores, conformações estendidas das cadeias laterais alifáticas seriam menos favorecidas, devido à presença de outros grupos ésteres nas cadeias vizinhas (em maior proporção em comparação aos derivados de menor GS). Conformações estendidas, do tipo zig-zag, levaria 
a repulsão estérica. Neste caso, conformações pregueadas, de menor volume, seriam favorecidas, diminuindo a distância entre cadeias.

Devido às análises terem sido, incialmente, realizadas no intervalo de 5 a $50^{\circ}$, o cálculo do espaço interplanar para os hexanoatos de celulose foi impossibilitado devido ao pico estar fora do intervalo de análise. Assim, novas análises foram realizadas, monitorandose ângulos inferiores (a partir de $3^{\circ}$ ), e os resultados se encontram na Figura 33.

Figura 33 - Difratogramas de raios $X$ para os hexanoatos de celulose obtidos em meio homogêneo.

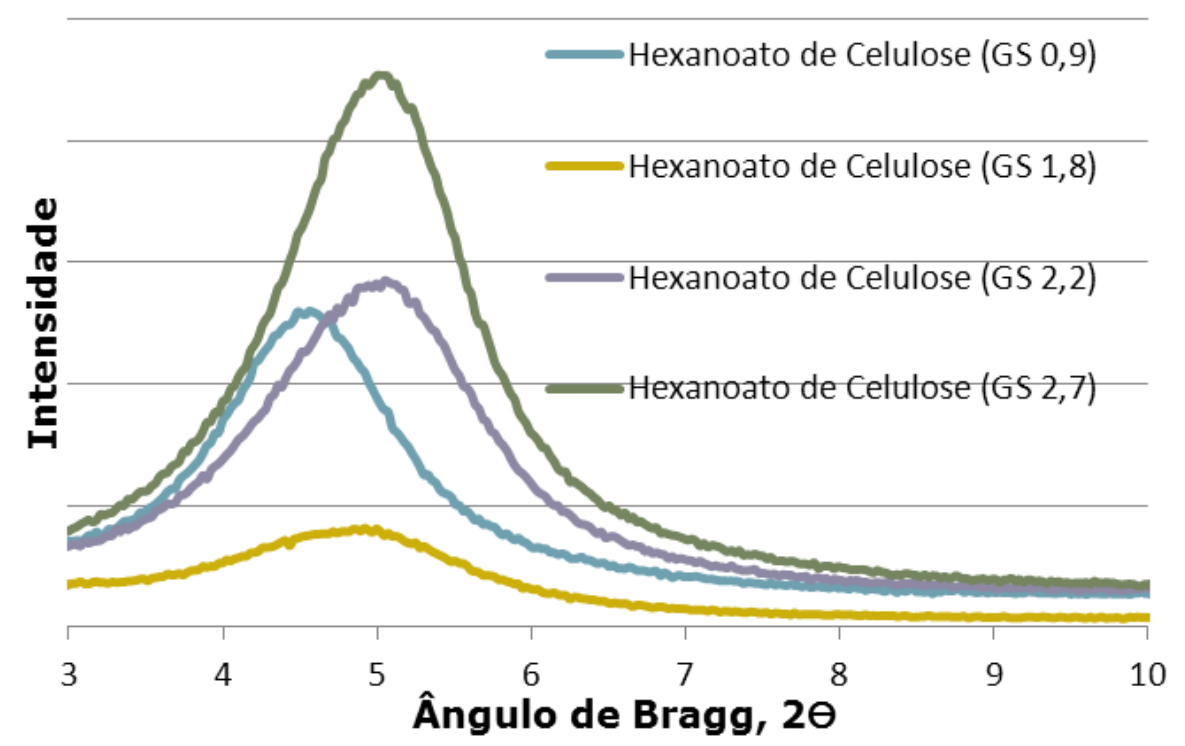

Observa-se que o pico em $2 \theta=5,0^{\circ}$ (Figura 33) se encontra em para regiões de menores ângulos para os hexanoatos de celulose em comparação com os butanoatos de celulose (Figura 32). Este fato comprova a maior distância interplanar gerada pela introdução de um grupo maior (hexila). Aplicando-se a equação de distância interplanar (Equação 4), obteve-se para os hexanoatos de GS 0,9, I,8, 2,2 e 2,7, distâncias interplanares de valores iguais a I,95, I,8I nm, I,73 e I,73 nm, respectivamente. Assim com observado para os butanoatos de celulose, ocorre a diminuição da distância interplanar com o aumento do GS de 0,9-2,2 provavelmente devido aos mesmos fatores atribuídos anteriormente para os butanoatos de celulose. Os hexanoatos de GS 2,2 e 2,7 apresentaram distâncias internaplanares iguais, o que indica que acima de GS 2,0 ○ número de grupos éster introduzido em cadeias vizinhas é suficiente para praticamente impedir conformações mais estendidas dos grupos laterais, ou seja, aumentar ainda mais o número de grupos laterais já não mais impacta a distância interplanar. 
Os difratogramas obtidos para os acetatos de celulose (figuras não mostradas) apresentaram uma razão ruído/sinal muito alta. Futuros estudos serão conduzidos visando minimizar os ruídos para a obtenção de difratogramas mais adequados para uma análise mais consistente. Não obstante, uma análise de caráter preliminar, a ser confirmada posteriormente, mostrou que acetatos de celulose com GS 0,7, 1,3 e 1,8 apresentaram espaços interplanares nos valores de 0,96, 0,97 e 0,98 nm, respectivamente. Observa-se que estes valores são menores que aqueles para os butanoatos e hexanoatos de celulose. A diminuição observada pode ser atribuída à presença de um grupo éster menor (grupo acetato). Os valores obtidos não mostraram diferenças significativas em função de GS, o que seria consequência do fato de estes grupos $\left(\mathrm{OCOCH}_{3}\right)$ não serem passíveis de rotações $\mathrm{C}_{\mathrm{sp} 3}-\mathrm{C}_{\mathrm{sp} 3}$, ou seja, não ocorrem transições conformacionais nos grupos acetato.

\subsubsection{Análise Termogravimétrica}

Por meio da análise termogravimétrica, avaliou-se o comportamento térmico dos ésteres de celulose obtidos partir de celulose de sisal, preparados em DMAc/LiCl. Como anteriormente abordado, a compreensão dos processos de decomposição da celulose e seus derivados é de grande importância para a conversão termoquímica da biomassa (CHEN et al., 20|4). Entretanto, estes processos são de extrema complexidade e geralmente consistem de uma vasta gama de reações. A identificação da temperatura de decomposição via análise termogravimétrica estabelece os limites superiores de aplicações para os materiais. A empregabilidade dos ésteres de celulose nas mais diversas aplicações é fortemente influenciada pelos processos de decomposição e estabilização (LUCENA et al., 2003; MORGADO; FROLLINI, 20II).

Na Figura 34 é apresentada uma curva TG, com a respectiva derivada primeira, para um acetato de celulose obtido em meio homogêneo (GS 0,7), utilizando DMAc/LiCl como sistema de solvente. As curvas para todos os acetatos, butanoatos e hexanoatos não estão mostradas, devido a grande similaridade apresentada. 
Figura 34 - Curva TG e derivada primeira para o acetato de celulose de GS = 0,7 (atmosfera de $\mathrm{N}_{2}$, e razão de aquecimento de $20^{\circ} \mathrm{C} \mathrm{min}^{-1}$ ).

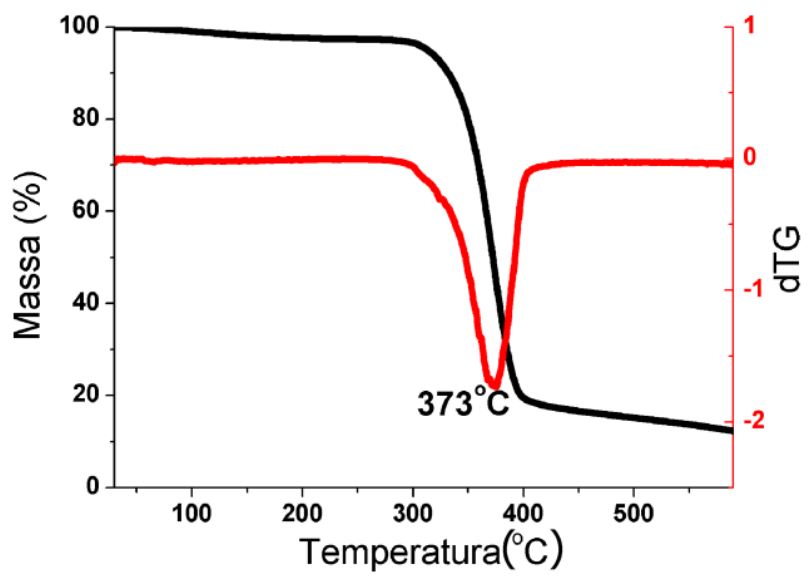

Pode-se atribuir importantes estágios de perda de massa à curva TG dos ésteres de celulose (Figura 34). O primeiro estágio, no intervalo entre $25-110^{\circ} \mathrm{C}$, é associado à evaporação de água residual absorvida/adsorvida. $O$ segundo estágio, presente no intervalo entre $240-430^{\circ} \mathrm{C}$ (com grande perda de massa), é atribuído à perda de grupos acilas presentes na estrutura dos ésteres de celulose e a cisão da cadeia polimérica. Acima de $500^{\circ} \mathrm{C}$ ocorre o fenômeno de carbonização dos produtos (MORGADO; FROLLINI, 20I I).

A decomposição térmica das fibras de celulose e de seus derivados ésteres consiste em uma vasta gama de reações de decomposição. Além da vaporização de água em torno de $100{ }^{\circ} \mathrm{C}$, ocorre, para os acetatos de celulose, a desacetilação em torno de $320^{\circ} \mathrm{C}$ para o diacetato e triacetato, e pirólise térmica do esqueleto de celulose em torno de $370^{\circ} \mathrm{C}$ para a celulose, acetato e triacetato (SAIRAM et al., 2003; BARUD et al., 2008).

Na Tabela 7 são encontradas as descrições dos parâmetros obtidos a partir das análises das curvas de TG dos ésteres analisados. 
Tabela 7 - Dados da decomposição térmica dos ésteres de celulose de sisal obtidos em meio homogêneo via análise termogravimétrica.

\begin{tabular}{|c|c|c|c|c|c|}
\hline Amostra & GS & $\mathrm{T}_{\mathrm{i}}\left({ }^{\circ} \mathrm{C}\right)$ & $\mathrm{T}_{\mathrm{f}}\left({ }^{\circ} \mathrm{C}\right)$ & $\mathrm{T}_{\mathrm{p}}\left({ }^{\circ} \mathrm{C}\right)$ & Perda de Massa (\%) \\
\hline \multirow{5}{*}{$\begin{array}{l}\text { Acetato } \\
\text { de } \\
\text { celulose }\end{array}$} & 0,7 & 298 & 410 & 374 & 79,4 \\
\hline & 1,3 & 298 & 420 & 373 & 77,1 \\
\hline & 1,8 & 303 & 422 & 381 & 78,1 \\
\hline & 2,5 & 273 & 445 & 387 & 81,9 \\
\hline & 3,0 & 274 & 438 & 393 & 80,1 \\
\hline \multirow{5}{*}{$\begin{array}{l}\text { Butanoato } \\
\text { de } \\
\text { celulose }\end{array}$} & 0,7 & 283 & 397 & 334 & 64,3 \\
\hline & 1,4 & 255 & 408 & 358 & 85,0 \\
\hline & 1,8 & 245 & 423 & 345 & 83,4 \\
\hline & 2,6 & 314 & 432 & 394 & 85,7 \\
\hline & 3,0 & 304 & 454 & 394 & 81,0 \\
\hline \multirow{5}{*}{$\begin{array}{l}\text { Hexanoato } \\
\text { de } \\
\text { celulose }\end{array}$} & 0,2 & 244 & 338 & 306 & 56,2 \\
\hline & 0,7 & 242 & 306 & 288 & $5 I, 7$ \\
\hline & I,8 & 230 & 402 & 372 & $8 I, 2$ \\
\hline & 2,2 & 238 & 435 & 375 & 89,4 \\
\hline & 2,7 & 238 & 438 & 370 & 83,2 \\
\hline
\end{tabular}

Ti - temperatura inicial; $T f$ - temperatura final; Tp - temperatura do pico de decomposição.

A presença de grupos substituintes no esqueleto da celulose pode ocasionar variações na estabilidade térmica do polímero. No geral, ésteres mais substituídos podem apresentar maior estabilidade térmica (temperatura inicial de decomposição, $\mathbf{T i}$, deslocada para maiores temperaturas) (BARUD et al., 2008). Observa-se que para os ésteres com diferentes tamanhos de cadeia, porém GS similares (acetatos, butanoatos e hexanoatos com GS I,8), $T_{i}$ diminuiu com $\circ$ aumento do tamanho da cadeia. Provavelmente, ligações hidrogênio intermoleculares, realizadas pelos grupos hidroxila remanescentes foram mais intensas quanto menor a cadeia lateral, pela proximidade maior das cadeias vizinhas.

Na Tabela 7, entretanto, diferentes tendências podem ser observadas para os ésteres com diferentes tamanhos de cadeia e GS. Para os acetatos de celulose, enquanto se observa uma relativa estabilidade de $T_{i}$ no intervalo de GS de 0,7-I,8 $\left(298-30{ }^{\circ} \mathrm{C}\right)$, um decréscimo em GS superiores (GS 2,5 e 3,0, 273-274 ${ }^{\circ} \mathrm{C}$ ) pode ser observado. Provavelmente, com o aumento do GS por introdução de grupos acetilas na cadeia carbônica, em substituição às 
hidroxilas, materiais que desenvolvem interações intermoleculares de menor intensidade são gerados. Assim, uma somatória de efeitos pode ser responsável pela tendência observada, tais como: a diminuição do número médio de hidroxilas ao longo do esqueleto celulósico, o que diminui o número de ligações hidrogênio ao longo da cadeia e, também, a intensidade das ligações hidrogênio envolvendo hidroxilas, uma vez que a introdução de grupos volumosos causa uma maior separação das cadeias.

Para os butanoatos de celulose, observa-se, até um GS I,8 (Tabela 7), a diminuição de estabilidade térmica, pela diminuição os valores de Ti. Entretanto, diferentemente do que é observado para os acetatos de celulose, conforme o GS aumenta $(2,6-3,0)$, aumentos consideráveis nos valores de Ti são observados e derivados mais estáveis termicamente são gerados. Provavelmente, conforme a acilação ocorre e grupos acilas maiores são introduzidos (butilas), a contribuição dos grupos hidroxilas remanescentes, em termos de ligações hidrogênio intermoleculares, são minimizadas em decorrência do afastamento intercadeias. Assim, em GS maiores, a contribuição de interações hidrofóbicas entre as cadeias ésteres substituintes é maximizada, o que pode ser responsável por gerar derivados termicamente mais estáveis. Nesta direção, observa-se a mesma tendência para os hexanoatos de celulose, sendo que, inicialmente, ocorre uma ligeira diminuição de Ti com o aumento do GS, seguido do aumento de Ti em GS superiores.

Ainda analisando a tendência observada para os butanoatos de celulose, outro fator que deve ser considerado diz respeito à como a esterificação avança, em relação à substituição das hidroxilas presentes nos carbonos C2, C3, C6. Como abordado anteriormente, em uma reação de esterificação da celulose, a hidroxila primária em C6 é a mais reativa (Seção 1.2.I). Na decomposição térmica da celulose, há uma grande importância na participação de $-\mathrm{C} 6 \mathrm{OH}$ (Seção 3.1.7). Este grupo participa da primeira etapa de decomposição da celulose, levando à formação de levoglucosana. Assim, assumindo que na esterificação há uma gradual e majoritária substituição de C6 em GS mais baixos, provavelmente a decomposição térmica envolvendo o grupo éster introduzido, C6COOR (onde R é o grupo alifático correspondente aos butanoatos e hexanoatos), pode ocorrer a menor temperatura, comparativamente à decomposição de $-\mathrm{C} 6 \mathrm{OH}$.

Conforme a reação de esterificação avança, aumenta a esterificação de C2 e C3, levando a C2COOR e C3COOR, gerando maior GS. No processo de decomposição térmica da celulose, $\mathrm{C} 2 \mathrm{OH}$ e $\mathrm{C} 3 \mathrm{OH}$, a princípio, participam de reações de decomposição 
que levam a formação de I,2-anidroglicose e 3-desóxiglucanose (MORGADO; FROLLINI, 201I). Assim, a mudança destes grupos para C2COOR e C3COOR pode ter sido responsável pelo deslocamento da decomposição térmica para temperaturas mais altas.

\section{3 Ésteres de celulose de sisal obtidos em meio heterogêneo}

Os avanços recentes que envolvem a modificação da celulose em meio heterogêneo são inúmeros e ilustram o potencial de crescimento desta área. Nesta direção, estudos sobre a obtenção de ésteres de celulose de sisal em meio heterogêneo foram realizados, visando comparar a eficiência das reações com aquelas realizadas em meio homogêneo, no que diz respeito ao GS dos ésteres obtidos. Fatores como o tempo de reação e consumo dos agentes esterificantes foram considerados.

Embora em meio homogêneo (Capítulo I, Seção 3.2) ésteres de celulose com tamanhos de cadeia variando de C2 (acetatos) a C6 (hexanoatos) tenham sido considerados, na presente investigação, em meio heterogêneo, considerou-se o estudo com o foco na obtenção de acetatos e butanoatos, este último como "representante" de ésteres de cadeias mais longas.

Como abordado anteriormente, nas reações do tipo heterogênea, envolvendo a celulose como substrato, a acessibilidade e reatividade dos grupos $\mathrm{OH}$ são, embora não somente, determinadas pelas etapas de ativação (onde ocorre a quebra das ligações hidrogênio), por exemplo, usando soluções alcalinas, como de $\mathrm{NaOH}$, ou pela interação com o meio reacional (intumescimento - "swelling'). Com este intuito, considerou-se também o uso de não solventes específicos para a celulose, como piridina e DMF, visando avaliar o intumescimento gerado e sua contribuição na ativação da celulose frente a diferentes agentes esterificantes. Ainda, o uso de catalisadores, como a própria piridina (catalisador nucleofílico) e iodo metálico foi considerado, visando à obtenção de agentes esterificantes mais eficientes. 


\subsubsection{Grau de Substituição (GS)}

Assim como para os ésteres obtidos em meio homogêneo, calculou-se o GS para os ésteres obtidos em meio heterogêneo por meio da relação entre a área correspondente à ressonância dos átomos de hidrogênio do anel de glicose $(\delta \sim 2,90-5,10$ ppm) e a área correspondente à ressonância dos átomos de hidrogênio do grupo éster correspondente $(\delta$ I,70-2,20 ppm), podendo ser obtido por meio da Equação 3.

Em um primeiro momento, considerou-se a preparação de ésteres de celulose em meio heterogêneo, baseando-se no método proposto por BISWAS; SHOGREN; WILLETT (2005). Esta reação é apoiada na grande eficiência do iodo como catalisador para álcoois primários e secundários, que foi recentemente demonstrada. Este catalisador é resistente à umidade, não causa impacto ambiental negativo e pode ser reciclado no caso de aplicação industrial. A Figura 35 mostra um esquema da reação de acetilação da celulose utilizando o iodo como catalisador.

Figura 35 - Mecanismo proposto para a reação de acetilação da celulose com anidrido acético, na presença de iodo como catalisador (BISWAS et al., 2007).

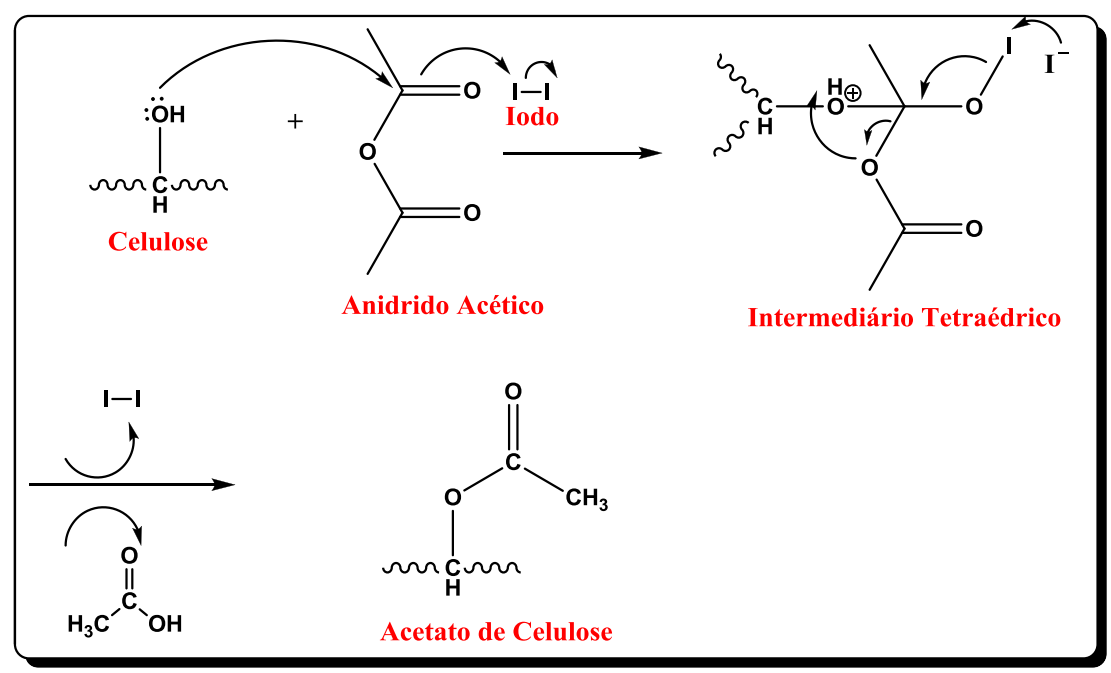

$\mathrm{Na}$ Tabela 8 são descritos os resultados de GS obtidos para os diferentes ésteres de celulose de sisal, obtidos em meio heterogêneo utilizando anidrido ácido e iodo metálico como catalisador. 
Tabela 8 - Resultados de grau de substituição para os acetatos e butanoatos de celulose, obtidos em meio heterogêneo.

\begin{tabular}{|c|c|c|}
\hline Éster de celulose & Tempo & GS Obtido \\
\hline \multirow{7}{*}{ Acetato de Celulose } & sem catálise de iodo $(3,0 \mathrm{~h})$ & 0,1 \\
\hline & $10 \mathrm{~min}$ & 0,3 \\
\hline & $45 \mathrm{~min}$ & 0,9 \\
\hline & $\mathrm{I}, 5 \mathrm{~h}$ & 1,6 \\
\hline & $2,0 \mathrm{~h}$ & 2,0 \\
\hline & $2,5 \mathrm{~h}$ & 2,3 \\
\hline & $3,0 \mathrm{~h}$ & 2,7 \\
\hline \multirow{3}{*}{$\begin{array}{c}\text { Butanoato de } \\
\text { Celulose }\end{array}$} & sem catálise de iodo $(3,0 \mathrm{~h})$ & -- \\
\hline & $3 \mathrm{~h}$ & 0,1 \\
\hline & $18 \mathrm{~h}$ & 0,3 \\
\hline
\end{tabular}

Pode-se observar que para os acetatos de celulose, a presença de iodo teve um caráter decisivo, pois quando ausente, um GS muito baixo foi obtido $(0,1)$, mesmo apesar de um longo tempo de reação (3 h) (PERES DE PAULA; LACERDA; FROLLINI, 2008). Quando realizado na presença de iodo, o tempo de reação foi o parâmetro utilizado para se variar o GS dos acetatos de celulose. Observa-se que, com o aumento do tempo, houve também aumento no GS obtido para os acetatos de celulose preparados em meio heterogêneo. Para os acetatos de celulose, a dependência do GS com o tempo de reação pode ser ajustada linearmente (Figura 36). Assim, podem-se obter acetatos de celulose com diferentes GS, via reação em meio heterogêneo, apenas controlando o tempo de reação. PERES DE PAULA; LACERDA; FROLLINI (2008) também mostraram uma dependência linear para a acetilação, em meio heterogêneo, da celulose de sisal. 
Figura 36 - Modelo gráfico da dependência dos GS com o tempo de reação para acetatos de celulose de sisal obtidos em meio heterogêneo.

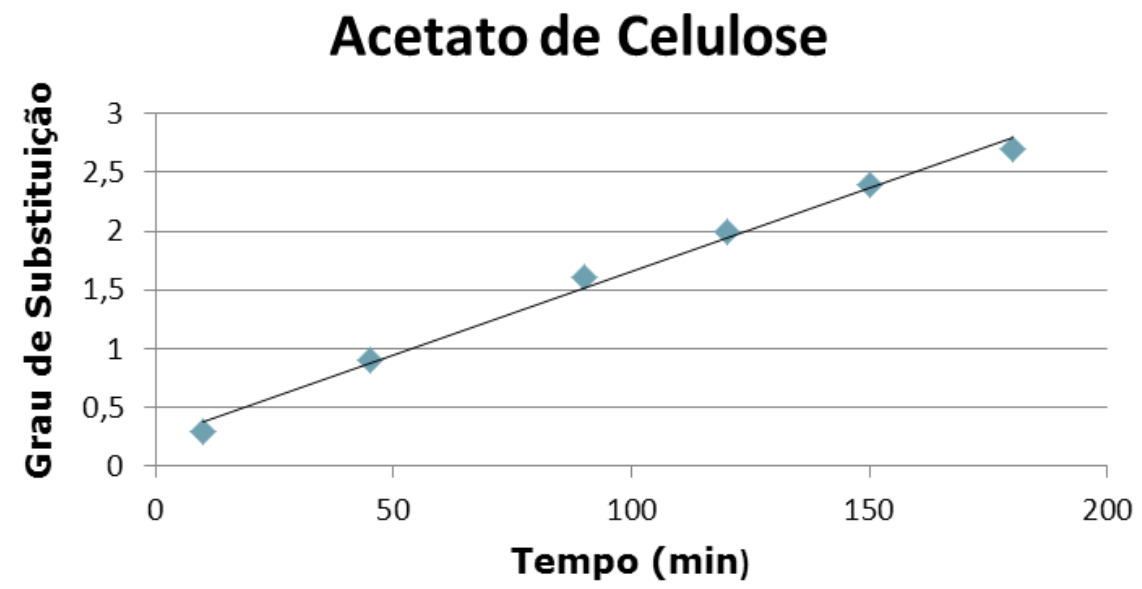

Para os butanoatos de celulose, entretanto, não se observou, com e sem catálise de iodo, modificação significante na celulose. Assim, baixíssimos graus de substituição $(0,1 ; 0,3)$ foram obtidos mesmo quando explorados tempos muito altos (I8 h) (Tabela 8). Em meio heterogêneo as substituições iniciam na superfície das fibrilas, o que torna difícil o acesso do reagente ao interior da matriz polimérica da celulose (PERES DE PAULA; LACERDA; FROLLINI, 2008). Assim, para anidridos de cadeias mais longas, o acesso aos sítios reativos da celulose é mais dificultado, quando comparado a anidridos de cadeias menores, como o acetato, tanto por efeitos estéricos quanto polares, visto a aproximação de cadeias mais longas e com alto caráter hidrofóbico (EDGAR, 2007). Assim, observa-se a ausência de modificação significativa da celulose quando utilizado o anidrido butanóico.

Devido aos resultados obtidos para cadeias mais longas utilizando o sistema anidrido ácido/iodo, novas rotas para a obtenção destes ésteres foram exploradas. A piridina foi considerada como solvente e também como um catalisador nucleofílico (Figura 37), visto que a reação deste nucleófilo com o agente acilante gera um intermediário muito mais reativo frente à celulose. 
Figura 37 - Mecanismo proposto para a reação de acilação da celulose com cloreto de butanoíla, na presença de piridina como catalisador nucleofílico (LIN; CHANG; HSU, 2009).

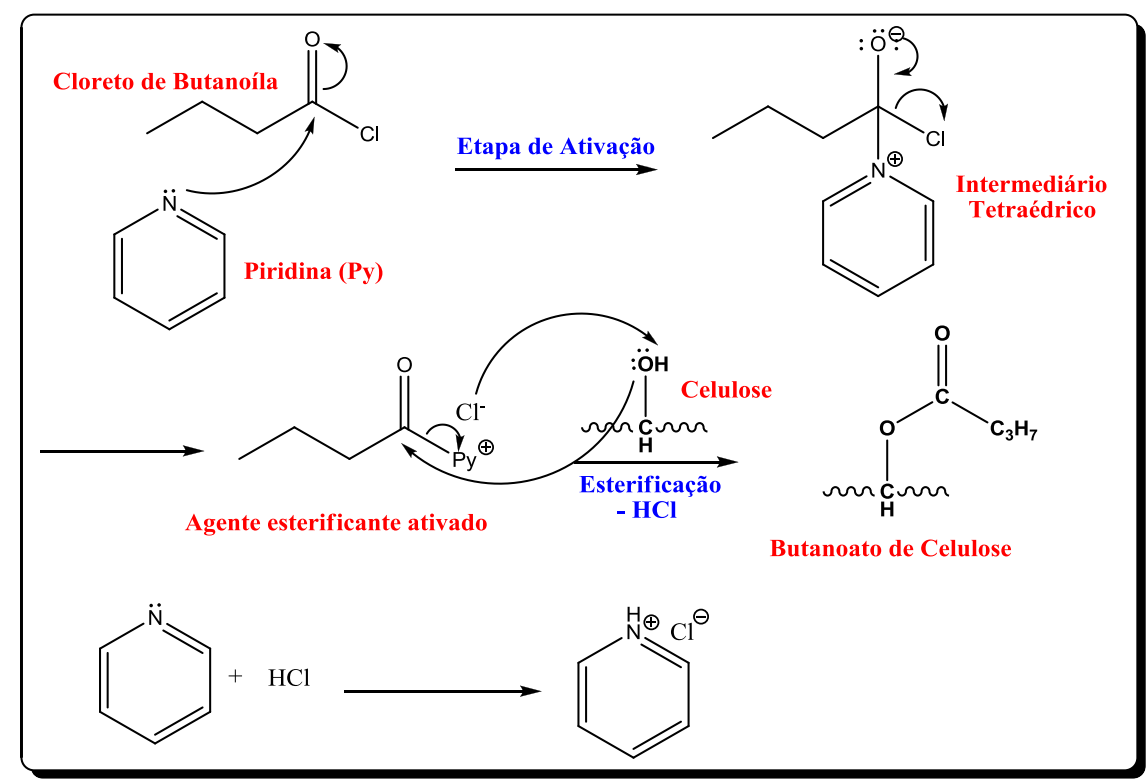

A piridina é usada como um catalisador nucleofílico, desde a preparação de ésteres de celulose a partir de ácidos orgânicos de cadeias longas (JANDURA; KOKTA; RIEDL, 2000; LEE; BLAKER; BISMARCK, 2009; RATANAKAMNUAN; MANOROM; INTHASAI, 20I3) até a preparação, a partir da benzoílação da celulose, de fases estacionárias (HE et al., 2007).

STAMM; TARKOW (1950) reportaram que fibras celulósicas e materiais lignocelulósicos, como a madeira, podem ser diretamente penetrados por solventes polares. A extensão a qual o líquido penetrará as fibras e as intumescerá depende diretamente da habilidade de intumescimento do líquido e da habilidade deste em formar ligações hidrogênio com os grupos hidroxilas da celulose ou lignina (no caso de materiais lignocelulósicos), e também do tamanho da molécula do solvente. MANTANIS; YOUNG; ROWELL (1995) reportaram um estudo onde vários solventes orgânicos foram avaliados quanto a suas capacidades de intumescimento em redes de fibras celulósicas. Neste estudo, MANTANIS; YOUNG; ROWELL (1995) verificaram que a piridina apresentou um alto poder de intumescimento em fibras de polpas sulfatadas, embora uma capacidade inferior em $\alpha$ celulose. $O$ intumescimento gerado pela piridina aumenta a reatividade com a celulose, pois leva a diminuição das ligações hidrogênio nas regiões não cristalinas, permitindo a penetração de reagentes nas fibras. Ademais, quando também usada como solvente, a 
interação da piridina com as hidroxilas celulósicas pode também contribuir na ativação da celulose para reações de substituição nucleofílica, uma vez que as interações do tipo cel-OH----:N-Pyr favorecem um maior deslocamento de densidade eletrônica na direção do oxigênio nucleofílico.

Os resultados obtidos durante esta etapa são apresentados na Tabela 9. Observa-se que as reações com o uso de cloreto ácido não foram realizadas na ausência de piridina (ou trietilamina), desde que a presença de uma base nas reações com cloretos ácidos é altamente recomendável, visto que há liberação de ácido clorídrico $(\mathrm{HCl})$ durante o curso da reação, e a presença deste é indesejável (desde que há possibilidade de ativação da carbonila do cloreto ácido, dificultando o controle da reação). $O$ uso de DMF foi também considerado, visando avaliar a sua influência como agente de intumescimento na ativação da celulose.

Tabela 9 - Resultados de grau de substituição para os butanoatos de celulose, obtidos em meio heterogêneo, na segunda etapa do projeto.

(I) Anidrido Butanóico/Piridina/lodo

$0,5-3,0$

(2) Cloreto de butanoíla/Piridina

(3) Cloreto de Butanoíla/Trietilamina/Piridina (cat.)

(4) DMF/Cloreto de Butanoíla/Piridina (cat.)

(5) DMF/Cloreto de Butanoíla/Piridina (cat.)

(6) DMF/Anidrido Butanóico

(7) DMF/Anidrido Butanóico/Piridina (catalisador)

$\begin{array}{ll}0,5 & 3,0 \\ 0,5 & 0,7 \\ 1,0 & 3,0 \\ 3,0 & 2.4 \\ 3,0 & 0,5 \\ 3,0 & 0,7\end{array}$

Primeiramente, visando à otimização do sistema anteriormente testado, no qual se considerou anidrido butanóico/catálise de iodo (Tabela 8), piridina foi usada como um agente de intumescimento para as fibras celulósicas e também como um possível catalisador nucleofílico, também considerando a catálise por iodo. Entretanto, observou-se que, nos tempos considerados (0,5-3 h), o sistema se mostrou ainda ineficaz para gerar substituição na cadeia celulósica [Reação (I), Tabela 9]. 
Quando considerada a piridina como meio de dispersão da celulose e, consequentemente, como catalisador nucleofílica da reação, o tempo total de reação $(0,5 \mathrm{~h})$ foi suficiente para gerar um éster de celulose completamente substituído [GS 3,0, Reação (2), Tabela 9]. A diferença no GS dos ésteres gerados nas reações (1) e (2) pode ser explicada por uma somatória de efeitos, entre eles a maior reatividade do cloreto ácido frente ao anidrido butanóico, e também maior reatividade frente à piridina, na geração de um intermediário mais reativo (catálise nucleofílica). Somando-se à maior reatividade do cloreto ácido frente ao anidrido ácido, tem-se, no primeiro caso, a piridina reagindo com o cloreto de butanoíla, com consequente deslocamento de $\mathrm{HCl}$ (uma molécula pequena, Figura 37). No segundo caso, entretanto, a reação da piridina com o anidrido butanóico envolve o deslocamento de uma molécula muito maior, no caso o ácido butanóico (Figura 38).

Em termos de eficiência, em meio homogêneo (Seção 3.2) não foi observado diferenças significativas na obtenção de acetatos e butanoatos de celulose a partir do uso dos respectivos anidridos ácidos como agentes esterificantes. Entretanto, em meio homogêneo, a solubilização da celulose leva ao rompimento das interações intermoleculares, por consequência da separação das cadeias e a influência da estrutura supramolecular da celulose é praticamente nula. Ainda, o afastamento das cadeias gerado pela solubilização da celulose facilita a aproximação de agentes esterificantes de cadeias mais longas, como no caso dos anidridos butanóico e hexanóico. Por outro lado, nas reações em meio heterogêneo, onde não há solubilização da celulose (apenas a suspensão), a influência da estrutura supramolecular da celulose é mais significativa e o acesso dos reagentes à matriz celulósica é mais dificultado. Assim, somando-se à menor reatividade do anidrido ácido frente ao seu respectivo cloreto ácido, têm-se, após a ativação com a piridina (quando esta ocorrer), intermediários reativos idênticos (Figura 37 e 38), entretanto com diferentes contra-ânions: Ânion cloreto, no caso do cloreto ácido, e um carboxilato, no caso do anidrido ácido. Por razões estéricas e polares, a aproximação do par agente esterificante ativado-íon cloreto à matriz celulósica é facilitada. 
Figura 38 - Mecanismo proposto para a reação de acilação da celulose com anidrido butanóico, na presença de piridina como catalisador nucleofílico (LIN; CHANG; HSU, 2009).

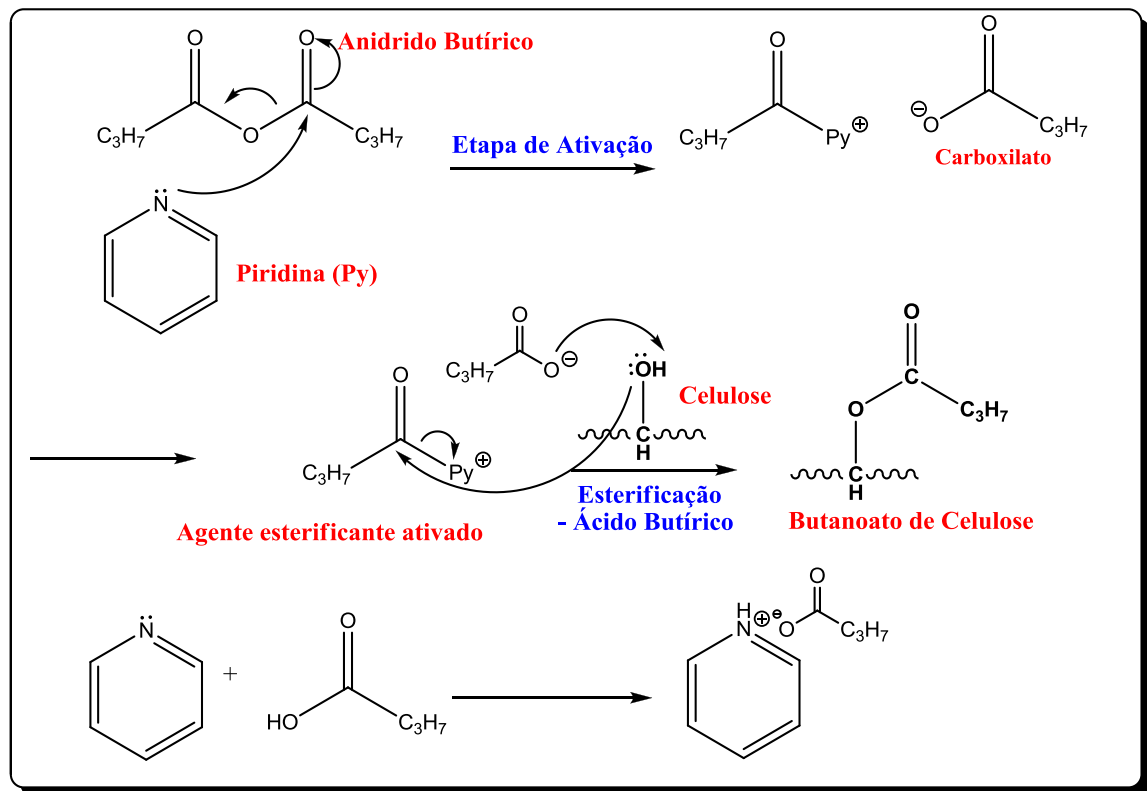

Assim, no estágio inicial, a reação com anidrido, um agente esterificante significantemente maior que o seu cloreto ácido correspondente, exige que uma molécula maior se aproxime do sítio reativo da celulose. Adicionalmente, no estado de transição, um grupo maior (um carboxilato, Figura 38) está se deslocando, em comparação a um íon cloreto no caso do cloreto de butanoíla (Figura 37). Ressalta-se, ainda, que o carbono carbonílico do cloreto de acila é mais eletrofílico que o do anidrido, e mesmo com a "dupla ativação" na reação (I), pelo iodo e pela piridina, esta reação foi muito menos eficiente que a reação (2).

Posteriormente, experimentos foram conduzidos em direção à minimização do uso da piridina no meio (uso apenas como catalisador, e não mais como solvente), desde que isso é de grande interesse em virtude da toxicidade deste composto em comparação a possíveis solventes orgânicos como substitutos. Os resultados confirmaram a menor eficiência do anidrido como agente esterificante [Tabela 9, reações (1), (6) e (7)], frente ao cloreto ácido correspondente, nas reações em meio heterogêneo. Nestas reações, obtevese um maior grau de substituição quando utilizado DMF como solvente, o qual possui um alto poder de intumescimento em comparação a outros solventes, como o tolueno (não provoca o intumescimento da celulose) (FREIRE, C. S. R. et al., 2006) e piridina como catalisador, levando a um grau de substituição de 0,7 em 3 horas [Tabela 9, reação (7)]. 
Como mencionado anteriormente, 0 intumescimento das fibras facilita $\circ$ acesso aos grupos hidroxilas disponíveis para a esterificação e, ainda, reduz o impedimento estérico na superfície das fibras. Conforme as fibras intumescem, as ligações intermoleculares são rompidas como resultado do estresse interno gerado pelo processo de intumescimento. Como consequência, o grau de ordenação ao longo da fibra é reduzido e acompanhado de um aumento na área de superfície das fibras (MANTANIS; YOUNG; ROWELL, 1995). FREIRE, C. S. R. et al. (2006) reportaram o uso de DMF em reações de esterificação parcial da celulose em meio heterogêneo, utilizando ácidos graxos $(\mathrm{C} 6, \mathrm{Cl} 2, \mathrm{Cl} 8$ e C22) como agentes esterificantes. Neste estudo, Freire et al. (2006) identificaram a influência do alto poder de swelling do DMF, obtendo GS superiores, em mesmas condições, em relação a utilização de tolueno. $\mathrm{Na}$ ausência de DMF, a reação mostrou ser ineficaz, mesmo na presença da piridina e do iodo metálico como catalisador [reação (I)]. Este fato comprova a grande influência exercida pelo DMF no meio reacional, ativando a celulose em reações de substituição nucleofílica. Em contrapartida, a substituição do anidrido butanóico pelo cloreto ácido correspondente [Tabela 9, reações (4) e (5)] levou a um éster completamente substituído (GS 3,0) em apenas Ih de reação [Tabela 9, reação (4)]. A princípio, tempos superiores à Ih levaram a clivagem da ligação éster e derivados de menor GS foram obtidos [Tabela 9, reação (5)]. 


\section{Breve Resumo e Conclusões Parciais}

Em linhas gerais, pode-se concluir que o processo de mercerização, empregado na polpa celulósica de sisal, foi eficiente para eliminação de hemiceluloses residuais e para levar a uma celulose de menor índice de cristalinidade, sem uma redução de GP significativa. A redução do teor de hemiceluloses foi muito importante, pois a presença destas, durante a funcionalização da celulose, pode interferir no GS do produto final devido à diminuição efetiva a interação da celulose/reagentes. A diminuição de cristalinidade agiu de modo a facilitar a dissolução da celulose no sistema de solvente $\mathrm{DMAc/LiCl}$ e também de modo a aumentar a acessibilidade dos agentes esterificantes à matriz celulósica, nas reações realizadas em meio heterogêneo.

Em meio homogêneo, ésteres de celulose com diferentes tamanhos de cadeia (acetatos, butanoatos e hexanoatos) e GS controlados foram preparados pelo ajuste da razão $\mathrm{Mol}_{\text {Anidrido }} / \mathrm{Mol}_{\mathrm{UAG}}$. A síntese de ésteres de celulose com efetivo controle do GS é de extrema importância no que tange a posterior aplicação destes derivados na preparação de materiais com propriedades bem definidas. A avaliação da estabilidade térmica dos ésteres de celulose, via análise termogravimétrica, revelou diferentes tendências com o aumento da cadeia do éster ou do GS para um mesmo comprimento de cadeia. Enquanto, para os ésteres de cadeia mais curta (acetatos), observou-se que $T_{i}$ diminuiu com o aumento do $G S$, para os ésteres de cadeias mais longas (butanoatos e hexanoatos), observou-se uma tendência oposta: inicialmente, $T_{i}$ diminuiu com o aumento do GS; contudo, aumentos consideráveis foram observados em $T_{i}$ em GS superiores.

Em meio heterogêneo, quando utilizado catálise de iodo e anidrido ácido como agente esterificante, apenas ésteres de cadeias curtas (acetatos) foram obtidos com alta eficiência. Para ésteres de cadeia maior, como os butanoatos de celulose, a reação em meio heterogêneo, nas mesmas condições usadas para os acetatos, mostrou ser ineficaz, o que fez necessário a busca por novas rotas. Assim, na busca de rotas alternativas para a obtenção de ésteres de cadeias mais longas, o uso de piridina como meio reacional e como catalisador nucleofílico, juntamente com um agente acilante mais poderoso que o anidrido ácido, o cloreto ácido de acila, levou a obtenção de butanoatos de celulose completamente substituídos, em um tempo relativamente curto (30 minutos). Entretanto, reações 
envolvendo a piridina em quantidade catalítica, usando como meio outra base, no caso a trietilamina, mostrou que a eficiência da síntese é deveras reduzida, levando a ésteres com baixos graus de substituição, no mesmo tempo considerado (GS 0,7, 30 minutos). $O$ uso de piridina como catalisador nucleofílico, juntamente com um cloreto de acila e DMF como agente de intumescimento, levou a obtenção de ésteres completamente substituídos, em um tempo relativamente curto (I hora). Assim, neste trabalho, pôde-se demonstrar a grande influência na escolha do agente esterificante (anidridos ou cloretos ácidos), catalisador (iodo metálico e/ou piridina) e a presença de um não solvente que intumesça as fibras celulósicas (piridina ou DMF) nas eficiências de reações realizadas em meio heterogêneo.

Os ésteres de celulose de sisal, preparados em meio homogêneo, foram usados como materiais de partida na preparação de filmes e biocompósitos, estes últimos consistindo da mistura de ésteres de celulose com celulose de sisal mercerizada. $O$ próximo capítulo abordará os resultados obtidos. 


\section{CAP 2. BIOCOMPÓSITOS A PARTIR DE ÉSTERES DE CELULOSE E CELULOSE DE SISAL}

Como mencionado anteriormente, este capítulo abordará o uso de ésteres de celulose de sisal, preparados em meio homogêneo (Capítulo I, Seção 3.2), na preparação de filmes e biocompósitos, estes últimos consistindo da mistura dos ésteres de celulose com celulose de sisal mercerizada. $O$ mesmo sistema de solvente utilizado na dissolução/acilação da celulose, DMAc/LiCl, foi utilizado na dissolução dos ésteres de celulose ou ésteres de celulose/celulose (biocompósitos). Um importante fator a ser considerado na dissolução da celulose e seus derivados é a possibilidade de ocorrer agregação das cadeias poliméricas no solvente utilizado. Os conceitos envolvidos na agregação serão discorridos nas seções a seguir.

\section{Introdução}

\section{I.I Agregação da celulose no sistema de solvente $\mathrm{DMAC} / \mathrm{LiCl}$}

Um fator importante no estudo da dissolução e derivatização da celulose é a possibilidade de ocorrer agregação (processo irreversível) elou associação (processo reversível) das cadeias de celulose e de seus derivados no meio em que se estes materiais encontram-se dissolvidos (BURCHARD, 2003; MORGADO; MARTINS; et al., 20II; RAMOS, L. et al., 20II; RODRIGUES et al., 20l4). Define-se como agregação as interações macromolécula/macromolécula em solução que são irreversíveis, enquanto que a associação de cadeias poliméricas consiste em interações temporárias e reversíveis, embora nem sempre o uso destes termos se prenda a esta definição. A agregação é responsável, em grande parte, pela dificuldade na acessibilidade dos reagentes em reações de modificação química (HULT; LARSSON; IVERSEN, 200I). 
Dois casos são possíveis na dissolução de um polímero: o caminho da esquerda (Figura 39; A, B, D e F) é usualmente observado para polímeros apolares ou de baixa polaridade e o caminho da direita (Figura 39; A, C, E, e F) pode ocorrer para polímeros polares que têm suas cadeias envolvidas em fortes interações intermoleculares, como no caso da celulose (SCHULZ; SEGER; BURCHARD, 2000).

Figura 39 - Estágio de dissolução de um polímero, (A) rede com cadeias associadas e regiões interligadas, (B; C; D, E) estágio intermediário e (F) completamente dissolvido (SCHULZ; SEGER; BURCHARD, 2000).

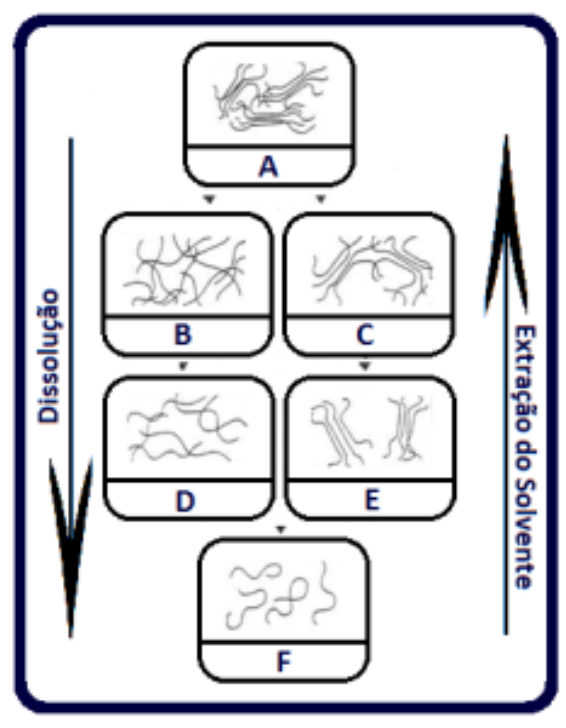

Schulz foi quem propôs o primeiro modelo, sugerindo vários estados coloidais presentes nas etapas de dissolução. De acordo com o modelo proposto a celulose, assim como seus derivados pouco substituídos, esta teria a dissolução interrompida no estágio coloidal, ou seja, dificilmente chegaria a um estágio de completa dissolução, com cadeias individuais solvatadas (Figura 39, F) (SCHULZ; SEGER; BURCHARD, 2000)

A inspeção visual não é, de fato, um critério seguro para assegurar a completa dissolução de um polímero, isto é, não é simples distinguir uma dispersão molecular de uma dispersão coloidal. Um teste rápido e simples consiste em manter um tubo de ensaio, contendo uma solução polimérica, contra a luz: se a solução for límpida e transparente, pareceria seguro afirmar que o polímero em questão está completamente dissolvido. No entanto, uma caracterização mais profunda via técnicas analíticas, como por exemplo, Espalhamento de Luz, poderia revelar massas molares muito maiores que as esperadas, como indicativo de agregação de cadeias poliméricas. Resultados de espalhamento de luz, 
utilizando-se DMAc/LiCl como solvente, indicam que a agregação é favorecida para celuloses com menores GP. Ainda, é observado que o aumento da concentração de $\mathrm{LiCl}$ promove a desestabilização dos agregados, mas favorece a associação das cadeias celulósicas solvatadas (TERBOJEVICH et al., 1985).

Os agregados têm sido encontrados em solução, dependendo das condições do processo de dissolução, tais como concentração de sal e celulose, bem como a fonte da qual a celulose foi extraída (RAMOS et al., 2005; MORGADO; MARTINS; et al., 20II; RAMOS, L. et al., 20II). A concentração ótima de $\mathrm{LiCl}$ na mistura $\mathrm{DMAc/LiCl}$ tem sido frequentemente descrita na literatura como sendo entre 5-9\% (RÖDER et al., 200I; ASS; CIACCO; FROLLINI, 2006; MORGADO; MARTINS; et al., 20II). TERBOJEVICH et al. (1985) reportaram agregados estáveis consistindo de sete cadeias de celulose, quando utilizado $5 \%$ de $\mathrm{LiCl}$. Outros autores descreveram soluções livres de agregados, obtidas apenas com um conteúdo de $\mathrm{LiCl}$ mínimo de $7 \%$, com concentração de celulose de até $1 \%$ (RÖDER et al., 200I).

A estrutura de agregados de celulose em $\mathrm{DMAc} / \mathrm{LiCl}$ tem sido frequentemente descrita em termos de "micelas franjadas" (Figura 40), nas quais as dimensões estão relacionadas ao raio de giração, sendo $(L)$ e $(r)$ referentes ao comprimento e área de seção transversal da micela, respectivamente (CIACCO et al., 2010). Pesquisas confirmam a formação de estruturas de "micelas franjadas" de moléculas de celulose solvatadas em DMAc/LiCl (YAN; ZHU, 2002; ZUGENMAIER, 2008; CIACCO et al., 20I0).

Figura 40 - Modelo de "micela franjada" para os agregados de celulose em DMAc/LiCl (CIACCO et al., 20I0).

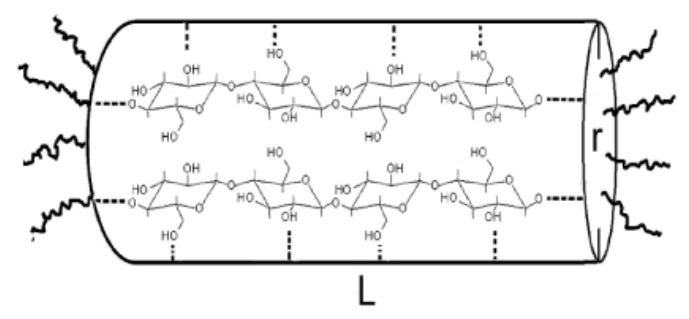

No presente trabalho, a possibilidade de agregação de cadeias de celulose no meio solvente foi utilizada sob uma perspectiva positiva, pois ésteres de celulose (previamente preparados) e celulose foram dissolvidos em $\mathrm{DMAc} / \mathrm{LiCl}$, visando a obtenção de filmes e biocompósitos. A formação de agregados de cadeias de celulose durante a dissolução, e a 
permanência destes agregados nos filmes, pode levar a matrizes de ésteres de celulose reforçados com celulose em escala nanométrica, em um processo de uma única etapa.

\section{I.I Aplicação dos ésteres de celulose em filmes e (bio) compósitos}

Em aplicação como filmes, os ésteres de celulose oferecem combinações únicas de tenacidade e transparência. Há uma gama quase ilimitada de cores, e os materiais são facilmente variados de transparente a opaco, passando por translúcido. Filmes de ésteres de celulose geralmente são relativamente fáceis de romper, apresentando baixo alongamento, e permitem facilmente a escrita sobre sua superfície. A exposição dos ésteres de celulose à umidade, no geral, não afeta em muito suas propriedades mecânicas. No geral, ésteres de celulose apresentam grande estabilidade à luz visível e ultravioleta. São suscetíveis ao ataque de ácidos e bases fortes, os quais podem ser usados para modificação de superfície ou degradação (EDGAR et al., 200 I; KLEMM et al., 2005).

Muitos estudos se direcionam para a busca de novas aplicações para os ésteres de celulose, principalmente aquelas que envolvem o uso de filmes, como exemplo, a obtenção de filmes ultrafinos de ésteres de celulose, visando à imobilização de enzimas (KOSAKA et al., 2007; YUAN et al., 20 I4), filmes fotobactericidas a partir de ésteres ou outros derivados de celulose (KROUIT; GRANET; KRAUSZ, 2008; KROUIT; GRANET; KRAUSZ, 2009), membranas para o uso de liberação controlada de drogas (EDGAR, 2007; ASHFAQ; KHAN; VERMA, 20I4), e até mesmo o uso de ésteres de celulose como fase de reforço em compósitos (QI; CHANG; ZHANG, 2008).

Compósitos obtidos de polímeros preparados a partir de matéria-prima oriunda de fonte renovável e fibras vegetais são considerados como novos materiais do século $\mathrm{XXI}$. Estes materiais respondem a questões relacionadas ao meio ambiente, por serem potencialmente biodegradáveis, após descarte, assim como à necessidade de desenvolvimento de materiais em que não se utilize, ou se utilize o mínimo, matéria-prima proveniente de fontes fósseis (MOHANTY et al., 2003). Esta tendência, iniciada nas últimas décadas do século $X X$ e consideravelmente impulsionada neste início de século, 
gradativamente deverá colocar estes materiais, em termos de mercado, no mesmo patamar de polímeros sintéticos. $O$ desenvolvimento de pesquisa nesta área com certeza em muito colabora para que esta meta seja mais rapidamente atingida. Dentre os biopolímeros que podem ser usados como matriz em biocompósitos destacam-se os plásticos de celulose, em que se inserem os ésteres de celulose. Os biocompósitos que têm ésteres de celulose como matriz, normalmente são preparados a partir da fusão do material, usando proporções razoáveis de agentes plasticizantes (MOHANTY et al., 2003), tendo em vista que a fusão do éster na ausência deste agente pode ser acompanhada de decomposição térmica. Outra possibilidade de obtenção de filmes consiste na preparação de soluções e posterior deposição por espalhamento em uma superfície, seguida e eliminação do solvente.

Destaca-se que a utilização de celulose como reforço de matriz de ésteres de celulose deverá eliminar, ou pelo menos minimizar, um dos grandes problemas de compósitos, que está relacionado à afinidade reforço/matriz. As interações reforço/matriz na interface têm grande influência nas propriedades do material final e, o uso de celulose, a qual apresenta grande semelhança estrutural em relação aos seus ésteres derivados, leva à expectativa de formação de interfaces com forte interação entre matriz e reforço (MORGADO; FROLLINI; et al., 20I I; ALMEIDA et al., 20I3).

Diversos estudos, neste âmbito, têm sido desenvolvidos ao longo das últimas décadas. Wibowo (2003) demonstrou a possibilidade de se obter biocompósitos a partir acetato de celulose e acetato-butanoato de celulose, como matrizes, usando-se fibras cânhamo como agente de reforço. $O$ uso de acetato-butanoato de celulose como matriz em biocompósitos reforçados com linho também é relatado (TORIZ et al., 2003). Destacam-se, também, outras aplicações onde a celulose tem sido constantemente empregada, tais como no preparo de filmes híbridos com argila organofílica (JANG; KIM; CHANG, 2009), atuando como agente de reforço em diferentes matrizes, como exemplo, o amido (LIU et al., 20I0), poliésteres insaturados (LEE; IYER; TORGET, I999; ADEL et al., 2010) e usada para a preparação de diferentes tipos de nanocompósitos (SOYKEABKAEW et al., 2009).

No presente trabalho, ésteres de celulose de sisal, preparados em meio homogêneo, foram usados na preparação de filmes, na presença ou não da celulose de sisal, também usada na preparação dos ésteres, visando avaliar uma possível ação desta última como

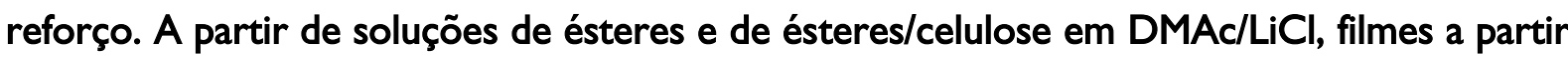
de acetatos de celulose, butanoatos de celulose e hexanoatos de celulose foram preparados 
e caracterizados. Trabalhos anteriores mostraram que cadeias de celulose podem se agregar neste sistema de solvente (DMAc/LiCl), gerando estruturas supramoleculares (MORGADO; MARTINS; et al., 20I I; RAMOS, L. et al., 20II). Nas condições que foram consideradas no presente trabalho, a formação destas estruturas pode levar a uma melhora em propriedades do filme, comparativamente a aqueles em que celulose não está presente (filmes preparados somente a partir de ésteres de celulose), devido ao possível efeito de reforço da celulose sobre a matriz de éster. 


\section{Experimental}

\section{I Preparação dos filmes/biocompósitos a partir de ésteres de celulose de sisal e celulose de sisal}

Para o preparo dos filmes e biocompósitos (matriz de éster de celulose; reforço de celulose) foram usados os ésteres preparados em meio homogêneo (GS 0,7-I,8, devidamente moídos em um moinho de facas analítico, Marca Marconi - Modelo MA048).

O sistema de solvente utilizado na solubilização dos ésteres de celulose/celulose foi o DMAc/LiCl sob procedimento idêntico ao descrito no Capítulo I, Seção 2.3।.I. A Figura 4I esquematiza o método de preparação dos filmes e biocompósitos utilizados neste trabalho.

Figura 4 I - Esquema de preparação dos filmes e biocompósitos a partir de soluções de DMAc/LiCl - (a) solução transparente a partir da dissolução do éster de celulose/celulose em DMAc/LiCl (24 h, sob agitação mecânica); (b) filtração da solução seguida de deposição em placas de petri e formação de material com consistência de gel; (c) lavagem dos matérias obtidos até eliminação do sistema de solvente; (d) filmes secos em estufa.

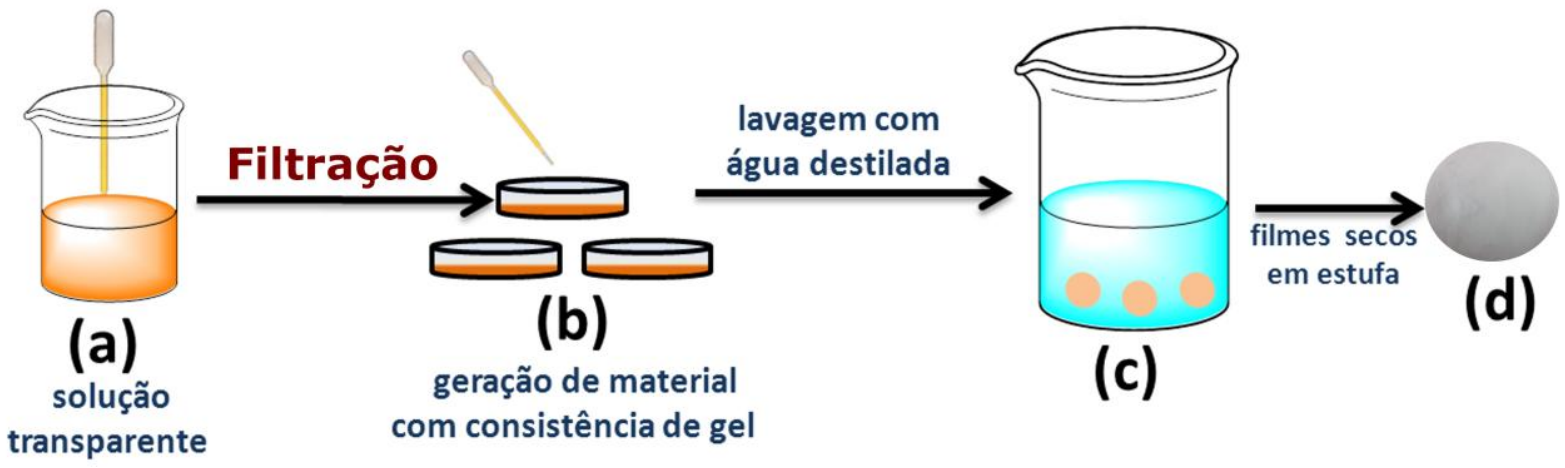

Após o período de $24 \mathrm{~h}$ de agitação, uma solução homogênea e transparente foi obtida [Figura 4I-(a)] e então filtrada, sob pressão positiva, através de discos $(47 \mathrm{~mm}) \mathrm{de}$ papel de filtro de microfibras de vidro (grau MGC, retenção de partículas em vidro: I,2 $\mu \mathrm{m}$ ). Imediatamente, após filtração, as soluções foram depositadas em placas de petri com o auxílio de uma pipeta de Pasteur descartável esterilizada, de plástico [Figura 4I-(b)]. Estas 
placas de petri foram deixadas à temperatura ambiente, por um período de $24 \mathrm{~h}$, tempo no qual um material tipo gel pôde ser formado, com consistência adequada para ser lavado. Com isso, os filmes foram exaustivamente lavados com água destilada por mais dois dias, imersos em um béquer de plástico $(4 \mathrm{~L})$, para eliminação do sistema de solvente (DMAc/LiCl) [Figura 4l-(c)]. As lavagens foram acompanhadas com sucessivas medidas de condutividade (Condutivímetro Modelo Schott Handylab LFI) para se acompanhar a eliminação de $\mathrm{LiCl}$. Posteriormente, realizou-se a secagem dos filmes em estufa de circulação a $45^{\circ} \mathrm{C}$ por $24 \mathrm{~h}$, e depois mais $4 \mathrm{~h}$ em estufa a vácuo a $60^{\circ} \mathrm{C}$, que foi suficiente para se observar massa constante [Figura 4I-(d)].

Diferentes filmes e biocompósitos foram preparados, sendo estes sumariados na Tabela 10. Filme de celulose (100\% celulose de sisal) foi também preparado e caracterizado, referido com a sigla "Cel".

Tabela 10 - Filmes e biocompósitos preparados a partir dos ésteres de celulose/celulose de sisal.

\begin{tabular}{|c|c|c|c|c|c|c|}
\hline Éster & \multicolumn{4}{|c|}{$\%$ celulose } & Sigla Filme & Sigla Biocompósito \\
\hline & 0 & 12,5 & 15 & 20 & ( $0 \%$ celulose $)$ & $(12,5,15,20 \%$ celulose $)$ \\
\hline Ac. Cel GS I,8 & $\mathrm{X}$ & $*$ & $*$ & $X$ & $\mathrm{Acl}, 8$ & $\mathrm{Acl}, 8 / \mathrm{X} \% \mathrm{Cel}$ \\
\hline But. Cel. GS 0,7 & $\mathrm{x}$ & $*$ & $*$ & $x$ & But0,7 & But0,7/X\%Cel \\
\hline But. Cel. GS I,4 & $\mathrm{X}$ & X & $\mathrm{X}$ & $X$ & But I,4 & Butl,4/X\%Cel \\
\hline But. Cel. GS I,8 & $\mathrm{X}$ & X & $x$ & $x$ & But I,8 & Butl,8/X\%Cel \\
\hline Hex. Cel. I,8 & $\mathrm{X}$ & $X$ & $\mathrm{X}$ & $\mathrm{X}$ & Hexl,8 & Hexl,8/X\%Cel \\
\hline
\end{tabular}

*X\%Cel $=12,5 ; 15 ; 20$.

**filmes sem reforço (0\% celulose) muito frágeis e quebradiços, causando difícil manuseio e caracterizações $\rightarrow$ considerou-se o apenas o preparo de biocompósitos com 20\% de celulose como reforço.

A escolha dos ésteres de celulose/GS que foram utilizados na preparação dos filmes/biocompósitos, sumariados na Tabela 10, foi realizada de forma que as análises permitissem correlacionar efeitos relacionados à mudança de GS em diferentes filmes a partir de um mesmo tamanho de cadeia lateral (butanoatos, GS 0,7-I,8), assim como efeitos relacionados à mudança do tamanho da cadeia lateral (acetato; butanoato e hexanoatos) em um mesmo GS $(I, 8)$. O efeito da adição de celulose (0-20\%) pôde ser estudado em filmes de 
ésteres com diferentes cadeias laterais e de mesmo GS $(1,8)$ e em filmes de mesma cadeia lateral (butanoatos) e GS diferentes.

\subsection{Caracterização dos filmes/biocompósitos a partir de ésteres de celulose/celulose de sisal}

\subsection{Absorção de lítio}

A análise de lítio nas amostras foi realizada por meio da técnica de absorção atômica, em um espectrofotômetro de absorção atômica Varian, modelo AA 240 FS, no laboratório de Saneamento do Departamento de Hidráulica da Escola de Engenharia de São Carlos (EESC), visando avaliar se havia lítio residual nos filmes. Toda a vidraria utilizada para o preparo das amostras foi lavada com uma solução de ácido nítrico $10 \%$ e depois enxaguada com uma solução de $\mathrm{KCl} 2$ ppm. Ambas as soluções foram preparadas com água mili-Q

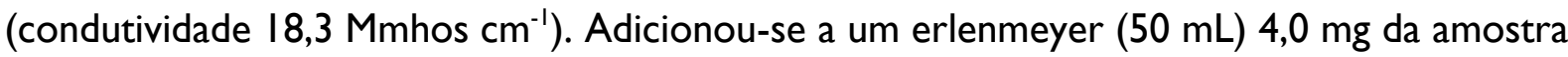
e aproximadamente $\mathrm{I} \mathrm{mL}$ de uma solução de ácido sulfúrico concentrado. Aqueceu-se a solução, agitando-se manualmente, até esta adquirir uma coloração escura. Adicionou-se então um pequeno volume de peróxido de hidrogênio, utilizando-se de uma pipeta Pauster, para clarear a solução. Aqueceu-se, novamente, para retirar o excesso de peróxido de hidrogênio. Deixou-se a solução esfriar por alguns segundos, posteriormente adicionando-se $30 \mathrm{~mL}$ da solução de $\mathrm{KCl} 2 \mathrm{ppm}$, transferindo-a assim para um balão volumétrico $(50 \mathrm{~mL})$, completando-a com a solução de $\mathrm{KCl} 2$ ppm.

\subsubsection{Análise Elementar}

Análise elementar foi utilizada a fim de detectar eventual presença do elemento nitrogênio, o que poderia indicar a presença de DMAc residual, nos filmes de celulose de 
sisal mercerizado, ésteres de celulose e biocompósitos. Utilizou-se de nitrogênio líquido para se obter um pó a partir dos filmes. A análise foi realizada no equipamento Perkin Elmer “Elemental Analysis 2400”.

\subsubsection{Difração de raios $X$}

Procedimento idêntico ao descrito no Capítulo I, Seção 2.2.4.

\subsubsection{Microscopia Eletrônica de Varredura (MEV)}

Procedimento idêntico ao descrito no Capítulo I, Seção 2.2.7.

\subsubsection{Análise Termogravimétrica}

Procedimento idêntico ao descrito no Capítulo I, Seção 2.2.8.

\subsubsection{Ensaios de Tração}

Os ensaios de tração dos filmes foram realizados em equipamento DMA, modelo 2980 da TA Instruments, nas seguintes condições:

Método: I $\mathrm{N} \mathrm{min}{ }^{-1}-18 \mathrm{~N}$

Modo: controle de força 
Pré carga: $0,001 \mathrm{~N}$

Dimensão média da amostra: Comprimento: $10 \mathrm{~mm}$ Largura: 5,3 mm

Garra: Tensão para filme

Os filmes foram previamente secos em estufa de circulação de ar a $110^{\circ} \mathrm{C}$, por $4 \mathrm{~h}$, acondicionadas em dessecador por $24 \mathrm{~h}$ para diminuição da umidade e padronização das condições de análise.

\subsubsection{Análise dinâmico-mecânica (DMA)}

As análises foram feitas em equipamento TA Instruments DMA 2980. As garras utilizadas foram do tipo Tension Film, com as seguintes dimensões dos filmes: (comprimento / largura): 10,0 / 5,3, sendo a frequência de I Hz, amplitude de $4 \mathrm{~mm}$, pré-carga de 0,25 $\mathrm{N}$ e razão de aquecimento de $3{ }^{\circ} \mathrm{C} \mathrm{min}-1$. As análises foram realizadas de $25^{\circ} \mathrm{C}$ a $200{ }^{\circ} \mathrm{C}$. 


\section{Resultados e Discussão}

\section{I Caracterização dos filmes/biocompósitos a partir de ésteres de celulose de sisal e celulose de sisal}

\section{I.I Análise elementar e absorção atômica de lítio}

Após o preparo dos filmes e biocompósitos, os mesmos foram submetidos a diversas lavagens com água destilada, para que houvesse a total remoção de $\mathrm{LiCl}$ e DMAc residuais.

Acompanhou-se a remoção de $\mathrm{LiCl}$ com sucessivas lavagens e consequente medida de condutividade da água de lavagem, a fim de se obter uma água de lavagem com uma condutividade igual ao da água destilada usada no processo.

Após a secagem completa dos filmes, os mesmos foram submetidos à análise de absorção atômica, com a finalidade de se comprovar a ausência do íon lítio nas amostras.

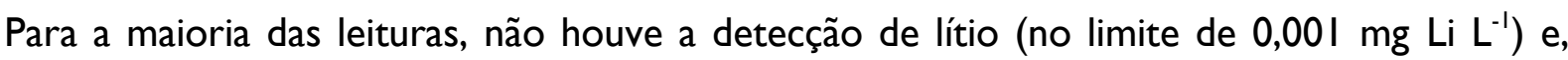
quando detectado, o mesmo estava presente em concentrações limites muito baixas. Isso comprova que todo o $\mathrm{LiCl}$ usado no sistema de dissolução da amostra pôde ser eliminado efetuando-se lavagens dos filmes com água destilada. Ressalta-se que a presença do sal poderia ocasionar efeitos indesejáveis na aplicação dos filmes.

Para se confirmar a ausência de DMAc nas amostras, estas foram submetidas a análise elementar, que é um procedimento que consiste na pirólise da amostra (análise destrutiva) e posterior análise dos gases resultantes de sua decomposição. Desse modo, pode-se avaliar a quantidade relativa de nitrogênio nas amostras. Em todas as análises foram encontradas quantidades percentuais menores que 0,1\% de nitrogênio, comprovando-se que as lavagens foram eficientes parar retirar praticamente todo o solvente, desde que a única fonte de nitrogênio presente seria devido a presença de DMAc. Na celulose de partida (celulose mercerizada), a quantidade percentual de nitrogênio encontrada foi de $0,01 \%$. 


\section{I.2 Microscopia Eletrônica de Varredura}

\section{I.2.I Filmes a partir de acetato de celulose de sisal}

A Figura 42 apresenta as imagens obtidas para as superfícies dos filmes a partir de acetato de celulose de sisal, GS I,8, e celulose de sisal mercerizada. É apresentado também, na Figura 42, o filme preparado a partir de celulose de sisal mercerizada.

Figura 42 - Micrografias das superfícies dos filmes de (a) celulose de sisal mercerizada, (b) acetato de celulose (GS I,8) e (c) biocompósito a partir de acetato de celulose GS I,8 e celulose de sisal (20\%).

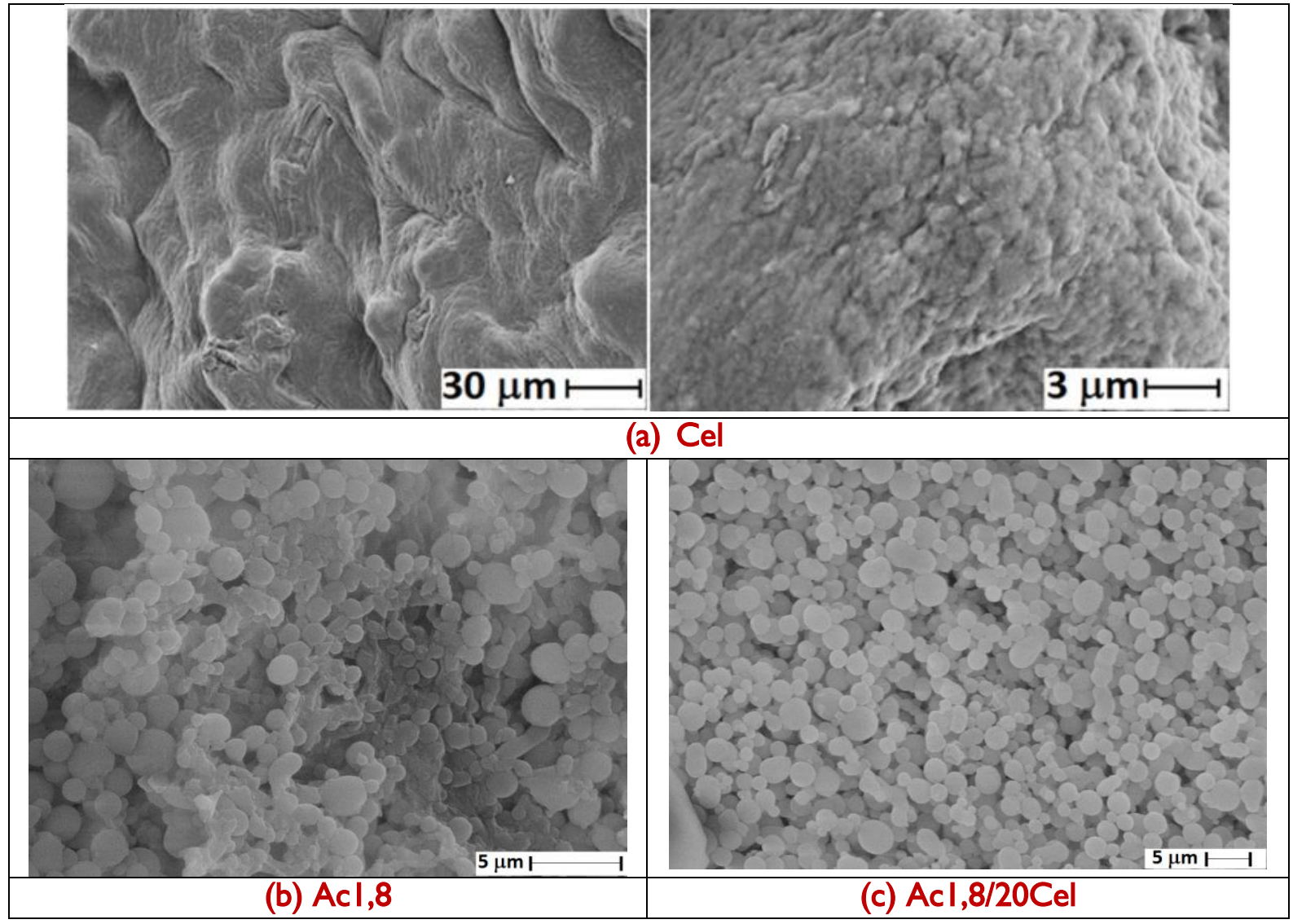

As imagens para o filme de celulose de sisal [Cel, Figura 42-(a)] mostraram uma superfície com um aspecto irregular e ondulado, apontando que agregados de cadeias de celulose foram provavelmente gerados na etapa de dissolução em DMAc/LiCl e, mesmo apesar de filtração ao final do processo de dissolução (papel de filtro de microfibras de 
vidro, retenção de partícula em líquidos: I,2 $\mu \mathrm{m}$, Seção 2.I), agregados menores podem não ter sido removidos e consequentemente sido responsáveis pela geração de agregados maiores durante a formação dos filmes. Além disso, a geração de novos agregados também pode ter acontecido durante a etapa de geração dos filmes.

Em outros trabalhos também inseridos neste mesmo grupo de pesquisa (MacromoLignoCell, IQSC/USP), filmes de celulose de linter mercerizada, também preparados em soluções de $\mathrm{DMAc/LiCl}$, exibiram superfícies similares, embora menos homogêneas e mais fibrosas (MORGADO et al., 2013) quando comparados aos filmes de celulose de sisal mercerizada preparados neste trabalho. Em estudos anteriores, RAMOS, L. et al. (20II) constataram que a celulose de linter exibe cadeias em um "estado de agregação" superior à celulose de sisal, corroborando o resultado aqui apresentado. Neste estudo de RAMOS, L. et al. (20II), realizado em DMAc/LiCl, atribuiu-se o resultado observado ao menor grau de polimerização viscosimétrico da celulose de linter em relação à celulose de sisal, o que favoreceu a agregação das cadeias de linter, assim como à presença de hemiceluloses na celulose de sisal, o que desfavoreceu a agregação.

Para o filme e biocompósito a partir de acetato de celulose de sisal de GS I,8, respectivamente Acl,8 [Figura 42-(b)] e Acl,8/20Cel [Figura 42-(c)], unidades globulares ao longo da superfície dos filmes foram obtidas, com dimensões que variam na faixa de 2-3 $\mu \mathrm{m}$. Destaca-se que a obtenção destas esferas com as dimensões observadas, a partir de soluções de $\mathrm{DMAc/LiCl}$, pode ser importante para a aplicação de liberação controlada de drogas (ALMEIDA et al., 20I3; MORGADO et al., 20I3). Em estudos anteriores, filmes preparados a partir de acetatos de celulose de linter (MORGADO et al., 2013) e a partir de acetato de celulose de sisal (ALMEIDA et al., 20I3), de GS 2,I e 2,2, respectivamente, também apresentaram microesferas em suas superfícies. Nestes estudos, a formação destes elementos globulares demonstrou ser favorecida pelo uso de acetatos de alto GS $(2, I-2,9)$.

ZHOU; CHEN (2008) investigaram a aplicação de microesferas de celulose/quitosana com núcleos e revestimentos hidrofóbicos como potenciais sistemas de liberação controlada de drogas, encontrando bons resultados para drogas com diferentes caráter hidrofílico. Mais recentemente, THAKKER et al. (2014) reportaram a preparação de microesferas consistindo de complexos interpoliméricos de quitosana e acetato-ftalato de celulose para carreamento de 5-fluorouacil, um importante agente antineoplásico. 
3.I.2.2 Filmes a partir de butanoatos de celulose de sisal

A Figura 43 e 44 apresentam as micrografias obtidas para os filmes preparados a partir de butanoato de celulose, com diferentes graus de substituições, e celulose de sisal. A Figura 43 apresenta micrografias referentes às superfícies, enquanto que a Figura 44 traz imagens referentes ao corte transversal. 
Figura 43 - Micrografias das superfícies dos filmes/biocompósitos preparados a partir de butanoatos de celulose com (a) GS 0,7; (b) GS 0,7 e 20\% de celulose; (c) GSI,4; (d) GS I,4 e $20 \%$ de celulose; (e) GS I,8 e (f) GS I,8 e $20 \%$ de celulose.

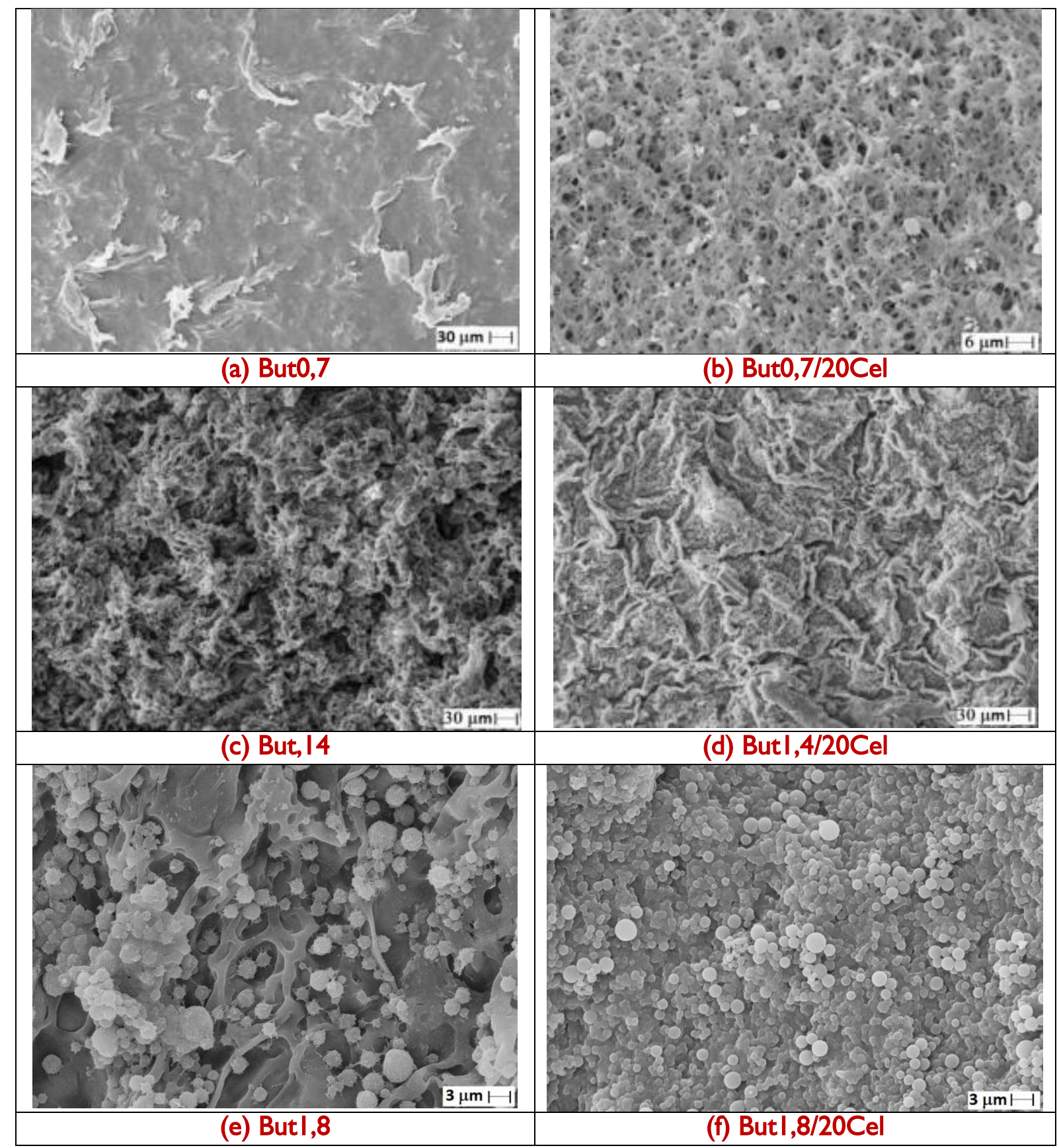


Figura 44 - Micrografias de cortes transversais dos biocompósitos preparados a partir de butanoatos de celulose de (a) GS 0,7 e (b) GS 0,7 e celulose de sisal (20\%).

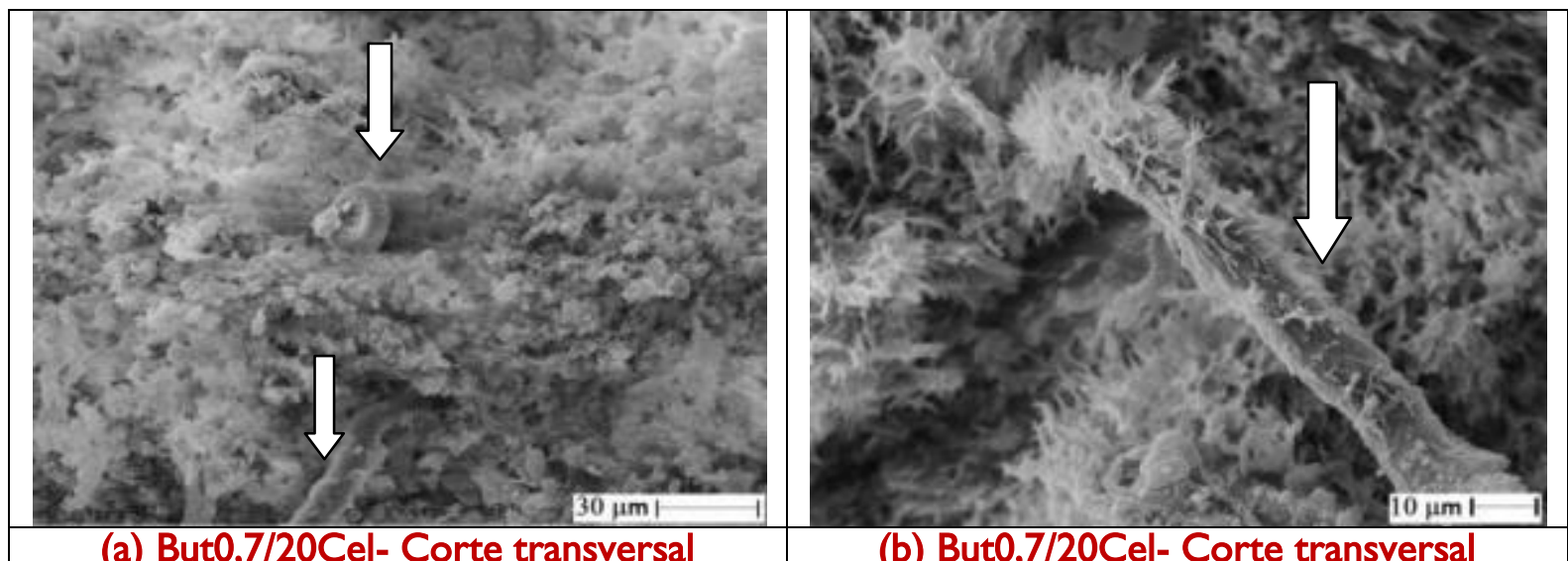

(a) But0,7/20Cel- Corte transversal

(b) But0,7/20Cel- Corte transversal

A partir da Figura 43 pode-se observar que o filme preparado a partir de butanoato de celulose de menor GS [But0,7, Figura 43-(a)] apresentou uma morfologia mais compacta e lisa quando comparado aos filmes preparados a partir de butanoatos de celulose com GS superiores [Butl,4 e Butl,8, Figura 43-(c) e (e), respectivamente]. Estes últimos apresentaram superfícies de aspecto mais fibroso, sendo que But l,8 [Figura 43-e] apresentou elementos globulares, analogamente ao filme preparado a partir de acetato de celulose, de mesmo GS. Para este mesmo filme, pode-se observar que a adição de celulose na composição [Figura 43-(f)] levou a uma superfície composta quase que em sua totalidade por elementos globulares. A adição de fibras na composição dos filmes preparados a partir de butanoatos de celulose de GS 0,7 e I,4 [Figura 43-(b) e (d), respectivamente] levou a uma superfície também com características fibrosas, sugerindo um rearranjo da celulose de sisal durante a formação do filme, formando estruturas supramoleculares.

As imagens obtidas para o corte transversal dos biocompósitos (na região de fratura pós-ensaio de resistência à tração) mostram estruturas fibrosas. As setas indicam regiões onde se podem observar estruturas semelhantes a microfibras, o que também seria um indicativo de um possível rearranjo da celulose de sisal durante a formação do filme [Figura 44-(a) e (b)]. Destaca-se que as dimensões destas estruturas fibrosas em escala submicrométrica $(10-12 \mu \mathrm{m})$ são outros indícios da formação de agregados durante a formação dos filmes e/ou da contribuição de agregados menores (após o processo de dissolução e filtração) na formação dessas estruturas, desde que particulados com dimensões superiores a I,2 $\mu \mathrm{m}$ ficariam retidos após filtração. A presença destas estruturas fibrosas 
pode ser considerada um indicativo da possibilidade de a celulose agir como um agente de reforço nas matrizes dos butanoatos de celulose aqui considerados, o que poderia levar a obtenção de materiais com propriedades superiores, como por exemplo, propriedades mecânicas (discutidas nas seções a seguir).

\section{I.2.3 Filmes a partir de hexanoato de celulose de sisal}

A Figura 45 apresenta as micrografias obtidas via MEV para os filmes/biocompósitos preparados a partir de hexanoato de celulose, GS I,8, e celulose de sisal.

Figura 45 - Micrografias das superfícies para os filmes/biocompósitos preparados a partir de hexanoatos de celulose de (a) GS I,8; (b) GS I,8 e 12,5\% de celulose de sisal; (c) GS I,8 e $20 \%$ de celulose de sisal; (d) GS I,8 e I5\% de celulose de sisal.

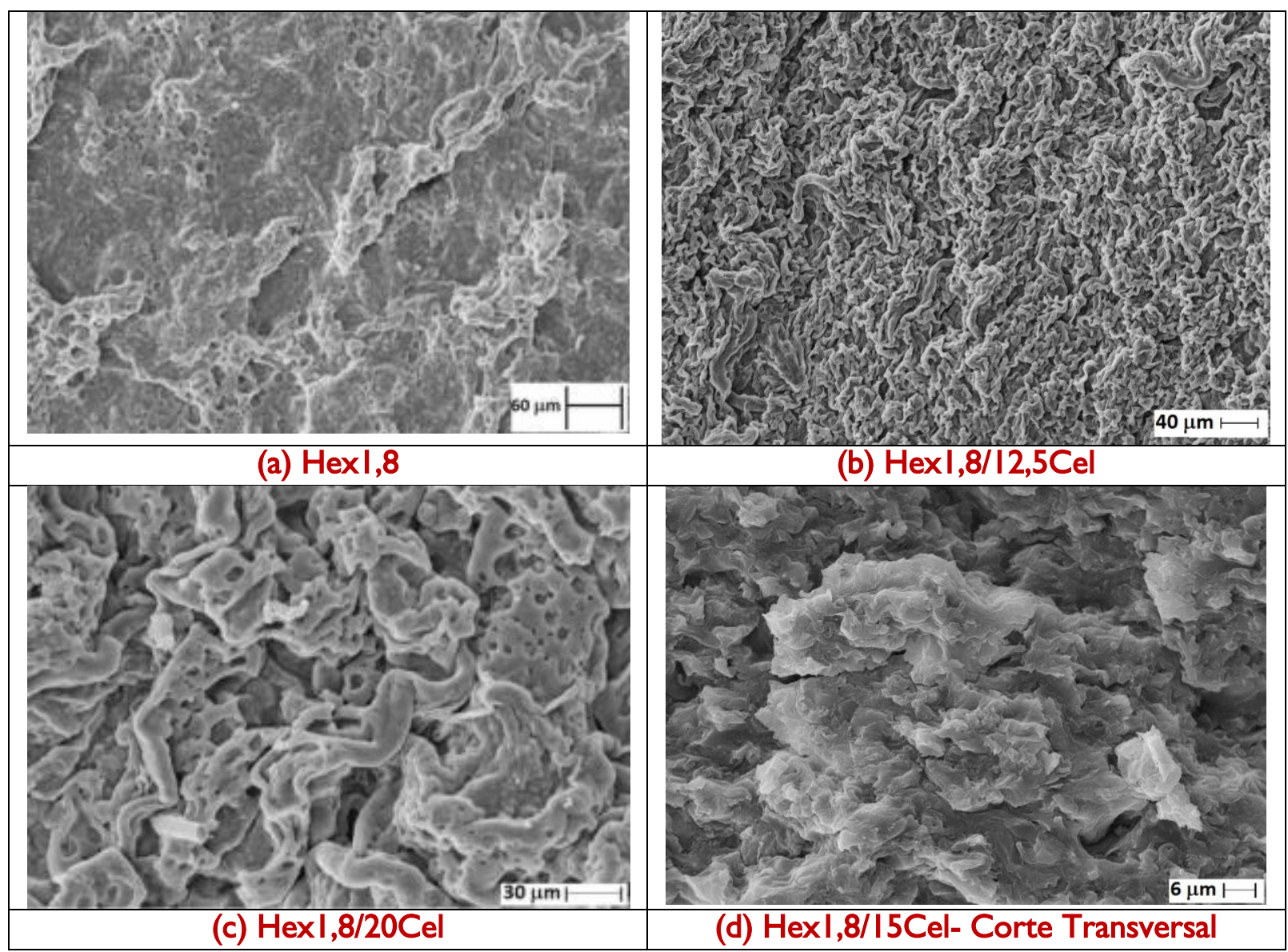


A partir da Figura 45, pode-se observar que o filme preparado a partir de hexanoato de celulose de GS I,8 [HexI,8, Figura 45-(a)] apresentou uma estrutura mais compacta frente aos biocompósitos, os quais apresentaram estruturas fibrosas em suas superfícies [Figura 45-(b) e (c)]. Este fato reforça o que foi observado para os filmes/biocompósitos preparados a partir de butanoatos de celulose (Figura 43, no que diz respeito à adição da celulose na composição e consequente formação de regiões que apontam a existência de estruturas supramoleculares fibrosas. Novamente, observa-se na imagem de MEV para o corte transversal do biocompósito [Hexl,8/I5Cel, Figura 45-(d)] que este, assim como para os biocompósitos a partir de butanoatos de celulose [Figura 44-(a) e (b)], apresentou estruturas sugerindo a presença de fibras. Mais uma vez, ressalta-se que a presença destas estruturas fibrosas pode ser considerada um indicativo de a celulose poder atuar como um agente de reforço na matriz de hexanoato de celulose.

\section{I.3 Difração de raios $X$}

Para os filmes/biocompósitos preparados a partir de ésteres de celulose de sisal/celulose de sisal, obtiveram-se difratogramas de raios $X$ e análises similares àquelas feita para os ésteres de partida (Capítulo I, Seção 3.2.2) foram realizadas.

Assim como abordado no Capítulo I, Seção 3.2.2, os perfis das curvas de raios $X$ para a celulose e seus derivados acetatos são muito semelhantes (Figura 30). Novamente, os difratogramas obtidos para o filme/biocompósito a partir acetato de celulose $(A c \mid, 8$ e Acl,8/20Cel, figuras não mostradas) apresentaram uma razão ruído/sinal muito alta. Futuras análises serão realizadas visando minimizar os ruídos para a obtenção de difratogramas mais adequados para uma análise mais consistente. Não obstante, a Equação 4 foi aplicada em uma análise de caráter preliminar, a ser confirmada o que levou a valores de espaços interplanares de 0,95 e 0,97 $\mathrm{nm}$ para o filme e seu respectivo biocompósito. 
A Figura 46 mostra os difratogramas obtidos para os filmes e biocompósitos a partir de butanoato de celulose de diferentes GS e celulose de sisal.

Figura 46 - Difratograma de raios $X$ para os filmes/biocompósitos a partir de butanoatos de celulose com (a) GS 0,7; (b) GS I,4 e (c) GS I,8.
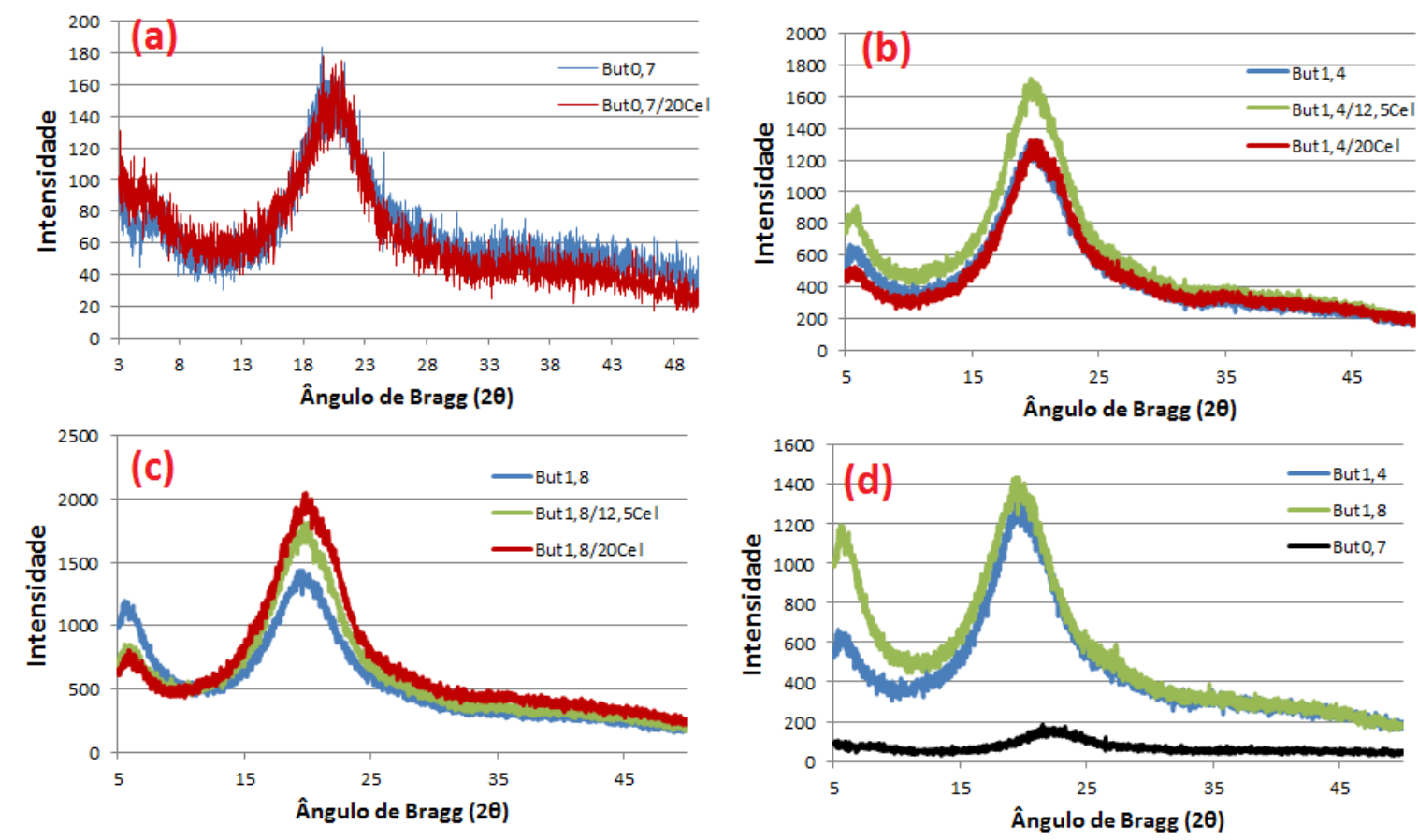

* Curvas para o biocompósitos com 15\% de celulose foram omitidas, para melhor visualização.

Para os filmes/biocompósitos preparados a partir de butanoatos de celulose com GS 0,7, I,4 e I,8 (Figura 46), não houve a variação da distância interplanar (calculado pela Equação 4) com a adição de celulose (entre as séries de filmes de mesmo GS), sugerindo que as cadeias de celulose se organizaram majoritariamente em domínios, pouco ou nada se inserindo entre as cadeias ésteres.

A distância interplanar foi maior para os filmes preparados a partir do butanoato de menor GS $(0,7)$, em relação aos filmes preparado a partir dos ésteres de GS superiores (GSI,4 e I,8 $\rightarrow$ distância interplanar de I,56 nm e I,47 nm, respectivamente). Para os butanoatos de GS 0,7 no intervalo de análise considerado, o pico a baixo valor de ângulo não foi observado, o que indica que o mesmo estaria abaixo de $3^{\circ}$ (Figura 46 a) e, portanto de acordo com Equação 4, o espaço interplanar seria maior que o dos demais.

Como explicado anteriormente (Capítulo I, Seção 3.2.2), a diminuição da distância interplanar, com o aumento do grau de substituição, deve-se provavelmente ao fato que, 
com a gradual introdução de grupos ésteres de cadeia longa na cadeia da celulose, as interações hidrofóbicas intermoleculares entre as cadeias vizinhas passam a ser cada vez mais intensas, gerando maior aproximação entre as mesmas. Adicionalmente, nos grupos butanoatos pode ocorrer rotação em torno da ligação $\mathrm{C}_{\mathrm{sp} 3}-\mathrm{C}_{\mathrm{sp} 3}$, gerando diferentes conformações, inclusive aquelas que podem ocupar menor volume. Em GS menores se tem ainda muitas hidroxilas livres, e as cadeias laterais alifáticas (grupos éster) podem assumir conformações mais estendidas, pois é alta a probabilidade da presença de hidroxilas (pequeno volume) nas cadeias celulósicas vizinhas. Por outro lado, em GS superiores, conformações estendidas das cadeias laterais alifáticas (grupo éster) seriam menos favorecidas, devido à presença de outros grupos ésteres nas cadeias vizinhas (em maior proporção em comparação aos derivados de menor GS). Conformações estendidas, do tipo zig-zag, levaria a repulsão estérica. Neste caso, conformações pregueadas, de menor volume, seriam favorecidas, diminuindo a distância entre cadeias.

Ainda, observa-se que, em relação aos butanoatos de celulose usados para preparar os filmes (Figura 32, em forma de pó), GS I,4 (I,58 nm) e GS I,8 (I,53 nm), as distâncias interplanares calculadas para os respectivos filmes foram ligeiramente menores (Figura 46, I,56 nm e I,47 nm, respectivamente). Esta pequena diferença poderia estar associada, a princípio, a um maior empacotamento das cadeias do polímero conforme o filme foi gerado, associado ao amplo intervalo de tempo fornecido para que houvesse deposição e organização das cadeias poliméricas.

A Figura 47 mostra os difratogramas obtidos para os filmes e biocompósitos a partir de hexanoato de celulose de diferentes GS e celulose de sisal. 
Figura 47 - Difratograma de raios x para os filmes/biocompósitos a partir de hexanoatos de celulose de GS I,0, GS I,8 e celulose de sisal.

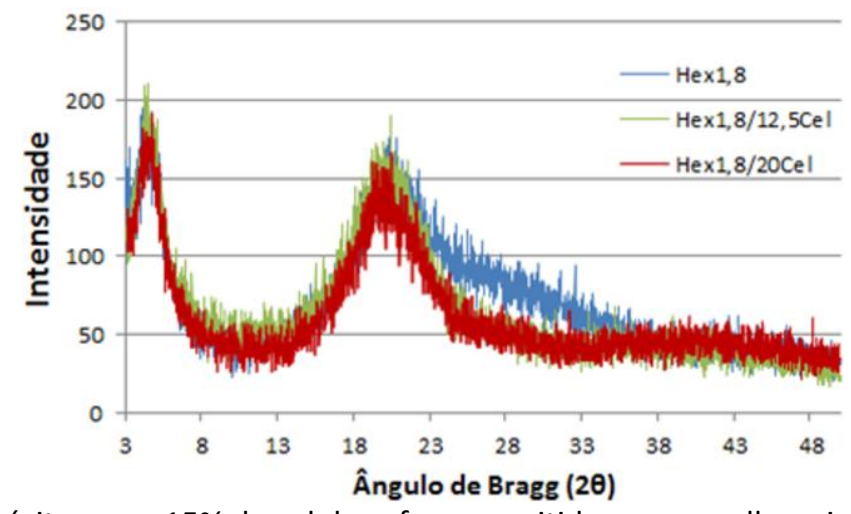

* Curvas para o biocompósitos com 15\% de celulose foram omitidas, para melhor visualização.

Novamente, pode-se observar que para os filmes/biocompósitos preparados a partir de hexanoatos de celulose com GS I,8, não houve variação na distância interplanar com a adição de celulose. A distância interplanar foi calculada como sendo 1,97 nm. Novamente, observa-se que esta distância interplanar é consideravelmente maior do que aquelas observadas para os filmes/biocompósitos preparados a de acetatos e butanoatos de celulose, o que pode ser atribuído à introdução de grupos substituintes hexilas, os quais são maiores que grupos butilas, gerando uma maior repulsão estérica entres estes grupos e/ou maior dificuldade de empacotamento das cadeias. Observa-se que o este valor de distância interplanar (I,97 nm) é ligeiramente maior que o observado para o hexanoato de celulose de partida (GS I,8, I,8I nm), sugerindo que neste caso, diferentemente do observado para os butanoatos de celulose, as cadeias de celulose podem ter parcialmente se distribuído entre parte das cadeias de ésteres. Neste caso, entre algumas cadeias de éster se teria cadeias de celulose (só com hidroxilas, de pequeno volume), favorecendo conformações mais estendidas dos grupos éster das cadeias vizinhas, o que poderia elevar o valor médio da distância interplanar. 


\section{I.4 Análise Termogravimétrica}

$\mathrm{Na}$ Tabela II são apresentados os dados obtidos nas curvas TG para os diferentes filmes e biocompósitos preparados a partir dos diferentes ésteres de celulose de sisal. Como as curvas TG/dTG para os filmes e biocompósitos são muito semelhantes às curvas obtidas para os ésteres de celulose de partida (Figura 34), as primeiras não foram mostradas.

Tabela II - Dados da decomposição térmica do filme de celulose de sisal e filmes /biocompósitos preparados a partir dos ésteres de celulose sisal e celulose de sisal.

\begin{tabular}{|c|c|c|c|c|}
\hline Filme & $\mathrm{T}_{\mathrm{i}}\left({ }^{\circ} \mathrm{C}\right)$ & $\mathrm{T}_{\mathrm{f}}\left({ }^{\circ} \mathrm{C}\right)$ & Perda de massa $2^{\circ}$ Estágio $\left(\mathrm{Ti}\right.$ a $\left.\mathrm{T}_{\mathrm{f}}\right)$ & $\operatorname{Tp}\left({ }^{\circ} \mathrm{C}\right)$ \\
\hline Cel & 273 & 424 & 79 & 361 \\
\hline $\mathrm{Acl}, 8$ & 308 & 423 & 76 & 381 \\
\hline Acl.8/20Cel & 312 & 442 & 80 & 370 \\
\hline But0,7 & 285 & 424 & 85 & 382 \\
\hline But0,7/20Cel & 260 & 410 & 83 & 344 \\
\hline But I,4 & 252 & 408 & 85 & 357 \\
\hline But I,4/I2,5Cel & 280 & 430 & 81 & 377 \\
\hline Butl,4/I5Cel & 265 & 412 & 81 & 332 \\
\hline But I,4/20Cel & 274 & 427 & 81 & 380 \\
\hline But I,8 & 242 & 426 & 83 & 368 \\
\hline But I,8/I2,5Cel & 240 & 434 & 83 & 370 \\
\hline But I,8/I5Cel & 240 & 444 & 82 & 372 \\
\hline But I,8/20Cel & 230 & 430 & 82 & 366 \\
\hline Hexl,8 & 227 & 433 & 81 & 363 \\
\hline Hexl,8/I2,5Cel & 230 & 428 & 80 & 360 \\
\hline Hexl,8/I5Cel & 235 & 426 & 81 & 355 \\
\hline Hexl,8/20Cel & 227 & 430 & 78 & 357 \\
\hline
\end{tabular}


A presença de grupos substituintes no esqueleto da celulose, em geral, ocasiona variações na estabilidade térmica do polímero. Observa-se que para os filmes/biocompósitos com diferentes tamanhos de cadeia, porém GS similares (acetatos, butanoatos e hexanoatos com GS I,8), $\mathbf{T}_{\mathbf{i}}$ diminuiu com o aumento do tamanho da cadeia, assim como a temperatura máxima de decomposição também se deslocou para valores menores. Ressalta-se que esta mesma tendência foi apresentada para os ésteres de celulose de partida (Capítulo I, Seção 3.2.2).

Analisando-se os dados da Tabela II, pode-se notar que, para os butanoatos de celulose, o aumento do GS levou a filmes com menor estabilidade térmica, com $T_{i}$ iniciando em temperaturas relativamente menores, com o mesmo efeito também em $T_{p}$, embora menos pronunciado. Esta tendência foi também observada para butanoatos de celulose de partida (GS 0,7-I,8, Tabela 7). Provavelmente, com o aumento do GS por introdução de grupos acilas na cadeia carbônica, em substituição às hidroxilas, materiais que desenvolvem interações intermoleculares de menor intensidade são gerados, contribuindo para a diminuição da estabilidade térmica observada.

Pela análise da Tabela II, observa-se que a adição de celulose à composição dos filmes não levou a mudanças/tendências significativas na estabilidade térmica.

\section{I.5 Análise Dinâmico-Mecânica}

A análise dinâmico-mecânica (DMA) tem como um dos principais objetivos relacionar as propriedades macroscópicas, tais como as propriedades mecânicas, às relaxações moleculares associadas a mudanças de conformação e a deformações microscópicas geradas a partir de rearranjos moleculares (CANEVAROLO JR., 2007).

Um fator importante a ser analisado, nesse trabalho, diz respeito ao valor do módulo de armazenamento, que é uma medida da energia mecânica que o material é capaz de armazenar, em determinadas condições experimentais, na forma de energia potencial ou elástica (WETTON, 1986; CANEVAROLO JR., 2007). A Figura 48 apresenta os valores de módulo de armazenamento, a $30^{\circ} \mathrm{C}$, para o filme de celulose e filmes de ésteres de celulose 
(com e sem celulose). Esta temperatura específica foi escolhida visando-se avaliar as propriedades dos materiais em aplicações próximas à temperatura ambiente.

Figura 48 - Módulo de armazenamento, a 30, para o filme de celulose de sisal e filmes/biocompósitos a partir de ésteres de celulose e celulose de sisal.

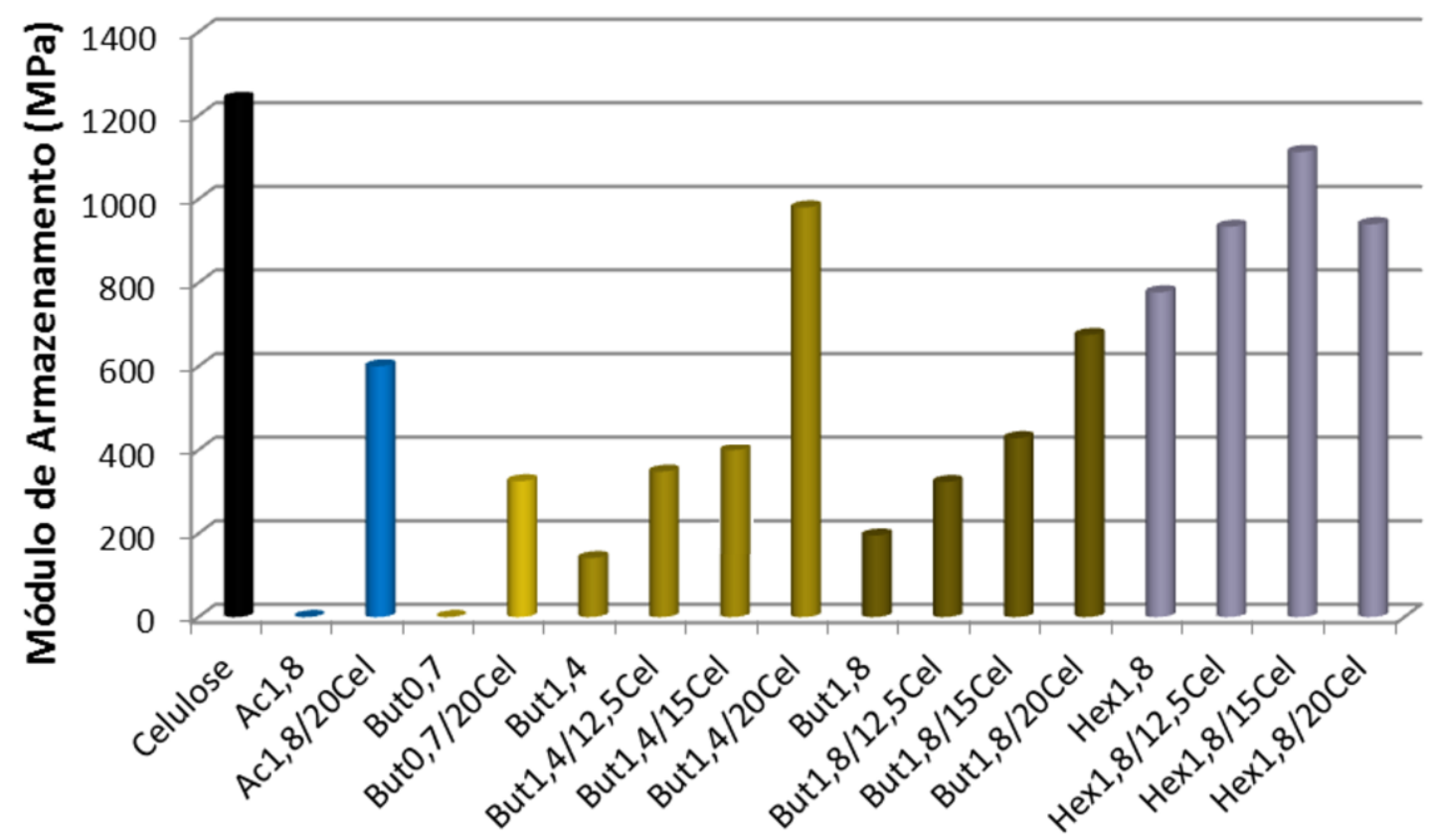

*os erros associados às medidas (triplicatas) variaram em um intervalo entre 5-10\%.

Os filmes a partir de acetato de celulose de sisal (GS I,8) e butanoato de celulose (GS 0,7), sem celulose, se mostraram quebradiços, não sendo possível a análise dos mesmos via DMA. Para os acetatos de celulose de altos GS, uma possível explicação residiria no fato que a diminuição do número de hidroxilas nas cadeias do acetato de celulose, em relação à celulose não derivatizada, pode levar a um filme com menor resistência, já que a presença de grupos acetilas ocasiona interações mais fracas do que a presença das hidroxilas, as quais realizam fortes ligações hidrogênio entre si. Para os butanoatos de celulose de menor GS $(0,7)$, entretanto, provavelmente a introdução de cadeias ésteres mais longas agiu tanto na direção de diminuir o número de hidroxilas livres, passíveis de realizar ligações hidrogênio, quanto também gerando um impedimento estérico, dificultando a aproximação de grupos hidroxilas e, portanto, de ligações hidrogênio intermoleculares.

Observa-se que, com o aumento do GS (butanoatos de GS I,4 e I,8), houve consequentemente um aumento da contribuição das interações hidrofóbicas intercadeias 
para os ésteres, levando a filmes com propriedades mecânicas superiores. É observado que, a introdução de celulose na composição destes filmes (acetato de GS I,8 e butanoato de GS 0,7), tornou possível as análises via DMA. Este resultado pode ser considerado como um indicativo que cadeias de celulose se agruparam durante a preparação de filmes, conforme sugerido pelos resultados de difração de raios $X$ discutidos previamente, gerando estruturas supramoleculares, as quais atuaram como um agente de reforço polimérico. Em trabalhos anteriores, onde foram preparados filmes a partir de acetatos de celulose de sisal e de linter (GS 2,0), reforçados com celulose, também pode-se observar o reforço por parte da fibra na matriz do éster (ALMEIDA et al., 20I3; MORGADO et al., 20I3).

Para os filmes a partir butanoatos e hexanoatos de celulose sem reforço, e de GS I,8, a realização das análises de DMA foram possíveis, contrariamente ao observado para os acetatos de GS análogo. A gradual substituição das hidroxilas presentes na cadeia da celulose (as quais realizam ligação hidrogênio inter e intramoleculares), por grupos acilas, geram derivados que realizam interações intermoleculares de intensidade inferior (interações do tipo van der Waals por parte dos grupos metilênicos da cadeia hidrocarbônica). Ainda que a carbonila do éster participe como uma doadora em de densidade eletrônica em ligações hidrogênio (-C=O---H-O), a intensidade desta é em parte reduzida pela separação das cadeias ocorrida pela introdução de grupos acilas, os quais são consideravelmente mais volumosos que os grupos hidroxilas. Em um estudo baseado em análises de infravermelho, WARWICKER; SPEDDING (1965) reportaram que os grupos hidroxilas remanescentes na parte não cristalina, após acetilação, realizariam ligações hidrogênio de menor intensidade, em comparação aos grupos hidroxilas das regiões não cristalinas da celulose. Neste mesmo estudo, WARWICKER; SPEDDING (I965) ainda demonstraram que o intervalo de força dessas ligações hidrogênio seria estreitado pela acetilação. Mais tarde, JANDURA; KOKTA; RIEDL (2000) reportaram resultados semelhantes, em um estudo também baseado em análises na região do infravermelho.

A introdução de grupos ésteres de cadeias mais longas (butilas e hexilas) resulta em um aumento das interações do tipo van der Waals (hidrofóbicas), em comparação ao grupo acetila, justificando o efeito crescente nos valores de módulo de armazenamento. Em direção a comprovar esta hipótese, nota-se que a performance referente ao módulo de armazenamento para o filme de hexanoato de GS I,8, sem reforço, foi superior ao apresentado pelos filmes de acetato de celulose (Figura 48, filme quebradiço, não analisado) 
e butanoato de celulose (Figura 48, $195 \mathrm{MPa}$ para $777 \mathrm{MPa}$ ), provavelmente resultante do aumento da cadeia lateral e consequente surgimento de interação mais intensas entre estas. É observado que, com exceção de HexI,8/20Cel, a adição de celulose como reforço levou a filmes com maiores módulos de armazenamento em relação aos filmes correspondentes sem reforço, apontando na direção que a celulose estaria agindo com um agente de reforço nas matrizes de ésteres de celulose.

Observa-se que o valor de módulo de armazenamento para o filme de celulose foi superior aos filmes e biocompósitos. Esse fato pode ser possivelmente justificado pela razão de as cadeias de celulose interagirem intensamente, devido à maior presença de hidroxilas, que promovem fortes interações, devido à realização de ligações hidrogênio. Destaca-se que a introdução da celulose na composição dos filmes foi responsável, na maioria das vezes, por aumentar os valores de módulo de armazenamento, consequentemente gerando filmes mais rígidos, sendo assim um indicativo que a celulose atua como um agente de reforço.

A Figura 49 apresenta os valores de temperatura de transição vítrea $\left(\mathrm{T}_{\mathrm{g}}\right)$ para os filme/biocompósitos, calculados a partir do máximo da curva de tan delta (não mostradas). Lembra-se que a $T_{g}$ está relacionada às rotações de ligações entre Csp $^{3}$ da cadeia principal, presentes nos domínios não cristalinos (CANEVAROLO JR., 2007). Do mesmo modo que a celulose não é passível de fusão, em vista da alta energia térmica que seria necessária (se decompondo antes de fundir), o fenômeno de transição térmica também não é observado para este polímero e, consequentemente, para o filme a partir deste. 
Figura 49 - Temperatura de transição vítrea para os filmes/biocompósitos preparados a partir de (a) acetato de celulose; (b) butanoatos de celulose; (c) hexanoatos de celulose.

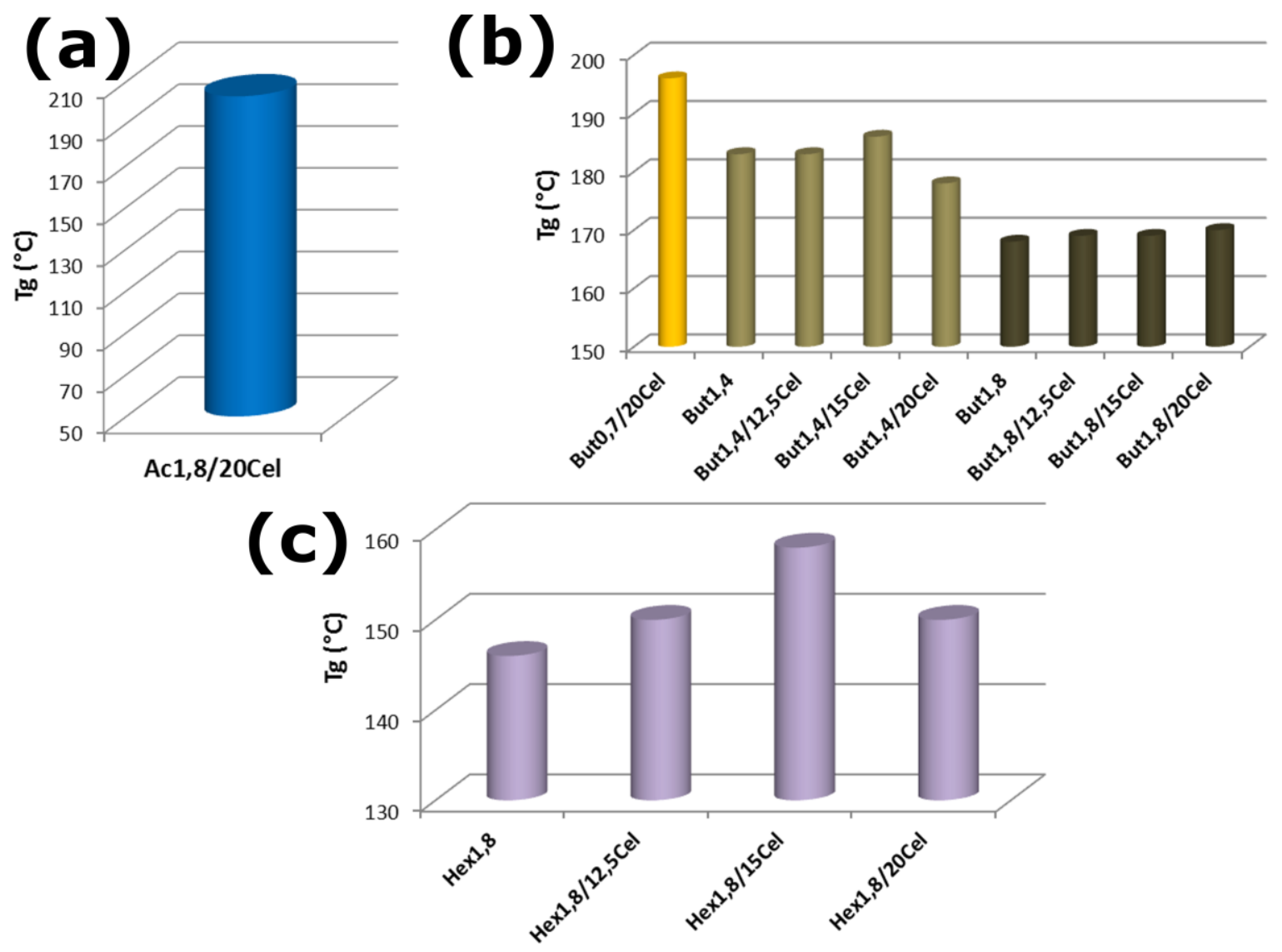

Observa-se, para as séries de filmes/biocompósitos apresentadas, que o valor de transição vítrea é fortemente dependente do tamanho da cadeia lateral substituinte e do GS. Para as séries de filmes/biocompósitos preparados a partir de ésteres com GS I,8, várias considerações devem ser feitas: para o biocompósito preparado a partir de acetato de celulose ( $20 \%$ celulose, desde para o filme puro não foi possível realizar análise), o valor de $\mathrm{T}_{\mathrm{g}}$ observado foi de $203{ }^{\circ} \mathrm{C}$, enquanto para os biocompósitos a partir de butanoatos de celulose o valor caiu para em torno de $170{ }^{\circ} \mathrm{C}$ e para aproximadamente $150{ }^{\circ} \mathrm{C}$, para os biocompósitos a partir de hexanoatos de celulose (Figura 49). A relaxação que ocorre na região de transição vítrea, também chamada de relaxação primária ou relaxação a para polímeros não-cristalinos e semi-cristalinos, é resultante dos movimentos que envolvem os segmentos da cadeia polimérica principal, influenciados diretamente pelos grupos substituintes ligados (FUKAYA et al., 2008). 
Em relação à cadeia lateral éster, com a introdução de grupos metilênicos conforme aumenta $\bigcirc$ tamanho da cadeia, há consequentemente um maior número de $\mathrm{Csp}^{3}$ introduzidos, o que possibilita transições conformacionais envolvendo rotações em torno de ligações s dos grupos n-propila (butanoato) e n-pentila (hexanoato). Estes grupos pendentes mais flexíveis, ligados à cadeia de celulose, permitem que os mesmos se adaptem mais facilmente ao volume livre existente entre as cadeias, o que leva a diminuição da Tg com o aumento da cadeia do éster, assim como observado na Figura 49. Adicionalmente, o maior afastamento das cadeias dificulta a aproximação das hidroxilas livres para interagirem via ligações hidrogênio, o que também atua no sentido de diminuir a $\mathrm{Tg}$.

Pode-se observar que, para os butanoatos de celulose (Figura 49), o aumento do GS levou a filmes/biocompósitos com menores valores de $\mathrm{T}_{\mathrm{g}}$. Com o aumento do GS, isto é, com a gradual substituição de grupos hidroxilas por grupos acilas, diminui-se a extensão de ligações hidrogênio, o que permite uma maior mobilidade molecular (GÓMEZCARRACEDO et al., 2003).

Ressalta-se que a variação da quantidade de celulose nos filmes não mostrou influência significativa nos valores de $T_{g}$ dos filmes, entretanto, no geral, valores de $T_{g}$ ligeiramente maiores foram observados na presença de celulose. Este fato indicaria que a interação da matriz polimérica com as cadeias celulósicas, na interface com os agregados de cadeias de celulose supostamente formados, dificultou a movimentação de segmentos de cadeias dos ésteres, levando a valores de Tg ligeiramente superiores. A influência mais pronunciada foi na série de filmes preparados a partir de hexanoatos de celulose com GS I,8, onde se observou que, inicialmente, os valores de $\mathrm{Tg}$ aumentaram com a adição de celulose (12,5-15\%), porém com um decréscimo quando considerado $20 \%$ de celulose. Efeito similar pode ser observado para a série de filmes preparados a partir de butanoatos com GS I,4. 


\section{I.6 Ensaios de tração}

$\mathrm{Na}$ Figura 50 são apresentados os resultados de tração para o filme de celulose e filmes de ésteres de celulose (com e sem reforço).

Figura 50 - Resistência à tração, a $30^{\circ} \mathrm{C}$, para os filmes/biocompósitos a partir de ésteres de celulose e celulose de sisal.

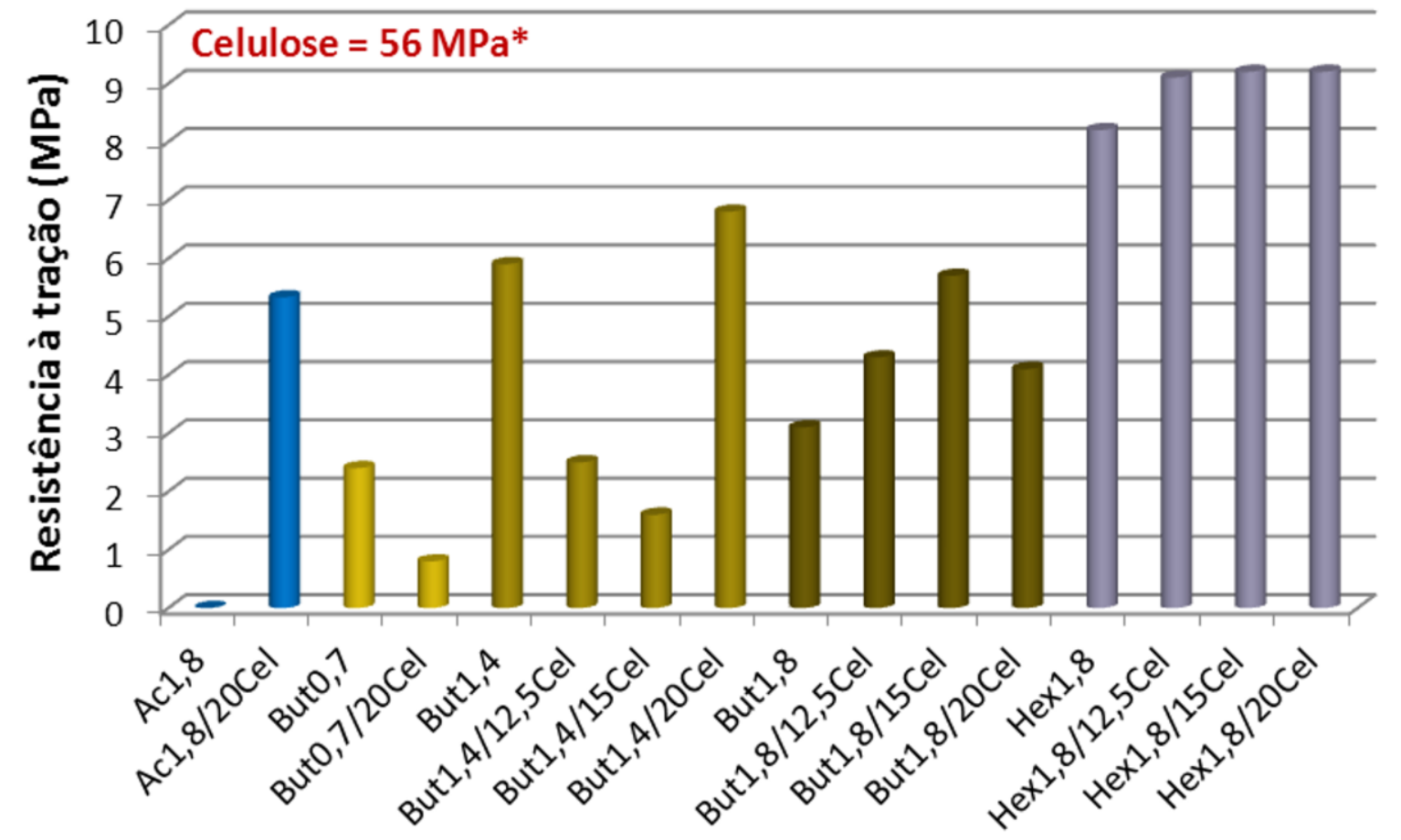

* valor não inserido no gráfico, em virtude da diferença de escala.

**os erros associados às medidas (triplicatas) variaram em um intervalo entre 4-9\%.

O filme de acetato de celulose de sisal $A c l, 8$, sem reforço, mostrou-se quebradiço, não sendo possível a análise do mesmo via ensaio de tração. Como já explicado na seção anterior, uma possível explicação reside no fato que a diminuição do número de hidroxilas nas cadeias do acetato de celulose, em relação à celulose não-derivatizada, pode levar a um filme com menor resistência, já que a presença de grupos acetilas ocasiona interações mais fracas do que a presença das hidroxilas, as quais realizam fortes ligações hidrogênio. Novamente, após a adição de celulose $(\mathrm{Acl}, 8 / 20 \mathrm{Cel})$ a análise se tornou possível, apontando o reforço da celulose na matriz do éster. 
Observa-se que, para os demais biocompósitos, a introdução da celulose levou a um reforço para série preparada a partir de ésteres GS I,8, com exceção de Butl,8/20Cel, com valores superiores de resistência à tração em relação aos filmes sem celulose. Pode ser observado, nas microscopias obtidas por MEV [But l,8/20Cel, Figura 43-(f)], que a introdução de celulose (20\%) nos butanoatos de GS I,8 levou a uma predominância de microesferas na superfície, assemelhando-se às superfícies dos filmes preparados a partir de acetato de celulose e de mesmo GS (Figura 42). Assim, provavelmente a presença destas estruturas globulares ao longo da superfície dos filmes/biocompósitos pode agir de forma negativa nas propriedades mecânicas destes, uma vez que a presença destas levou a filmes frágeis e quebradiços $(A c I, 8)$ e o aumento da presença levou a diminuição da resistência à tração (Butl,8/20Cel). Para os filmes preparados a partir de butanoatos de celulose com GS 0,7 e I,4, a introdução da celulose levou, a princípio, a resultados inferiores de resistência à tração (com exceção de Butl,4/20Cel, que apresentou resistência à tração superior aos demais biocompósitos e filme sem reforço).

Pode observar, pela análise da Figura 50, que para a mesma série de biocompósitos com GSI,8, o aumento da cadeia leva ao aumento da resistência à tração, reforçando a hipótese de que a introdução de grupos ésteres de cadeias longas acabaram por desempenhar interações mais intensas, do tipo van der Waals (hidrofóbicas), em comparação a grupos com cadeias de menor tamanho.

Quanto ao alongamento na ruptura (Figura 5I), observa-se que a introdução de celulose na composição levou, em quase todos os casos, a filmes mais rígidos. $O$ aumento da quantidade da celulose, em uma mesma série, levou ao aumento da rigidez, com valores de alongamento inferiores. Este efeito foi menos evidenciado para a série de filmes a partir de butanoatos de celulose de GS I,4. 
Figura $5 \mathrm{I}$ - Alongamento na ruptura, a $30^{\circ} \mathrm{C}$, para os filmes/biocompósitos a partir de ésteres de celulose e celulose de sisal.

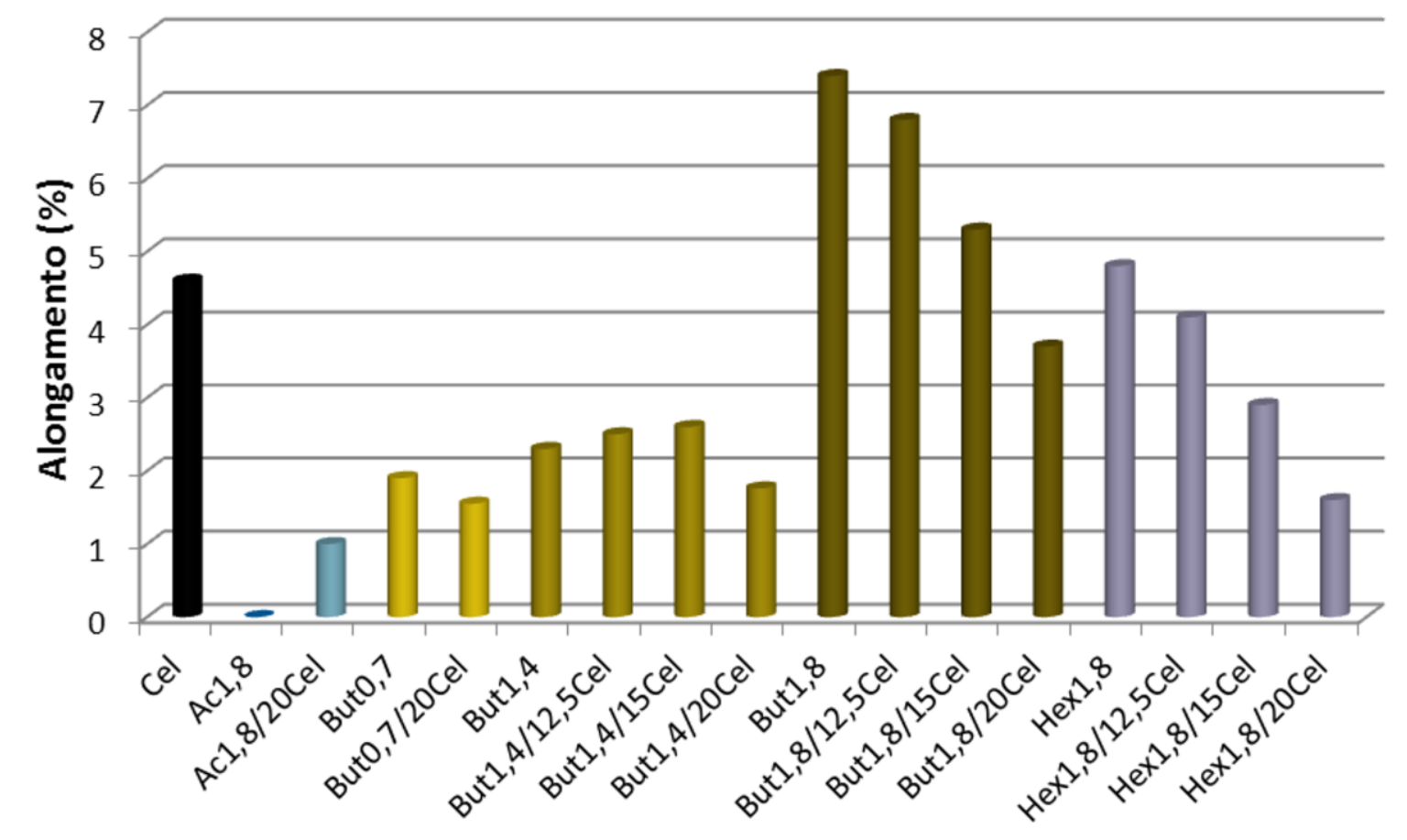

*os erros associados às medidas (triplicata) variaram em um intervalo entre 4-8\%.

Observa-se que, assim como para a análise de DMA, os ensaios de tração mostram resultados muito superiores para o filme de celulose. Isso é possivelmente justificado pela razão das cadeias de celulose serem mais firmemente ligada, devido à maior presença de hidroxilas, que promovem fortes interações, devido à realização de ligações hidrogênio. Entretanto, é válido observado que a introdução da celulose na composição dos filmes foi responsável, na maioria das vezes, por aumentar os valores de módulo de armazenamento, resistência à tração e módulo de tração, sendo assim um indicativo que a celulose atue como um agente de reforço da matriz de ésteres.

Os resultados de módulo de tração (Figura 52) corroboram com os resultados de alongamento na ruptura apresentados (Figura 5I). O módulo de tração é um parâmetro mecânico que busca mensurar a rigidez de um material sólido, e é uma propriedade intrínseca dos materiais, dependente da composição química, microestrutura e defeitos, podendo pode ser obtido por meio da razão entre a tensão exercida e a deformação sofrida pelo material. Assim, pode-se observar que a introdução de celulose, no geral, levou a filmes com maiores valores de módulo, logo filmes mais rígidos. 
Figura 52 - Valores de módulo de tração, a $30^{\circ} \mathrm{C}$, para os filmes/biocompósitos a partir de ésteres de celulose e celulose de sisal.

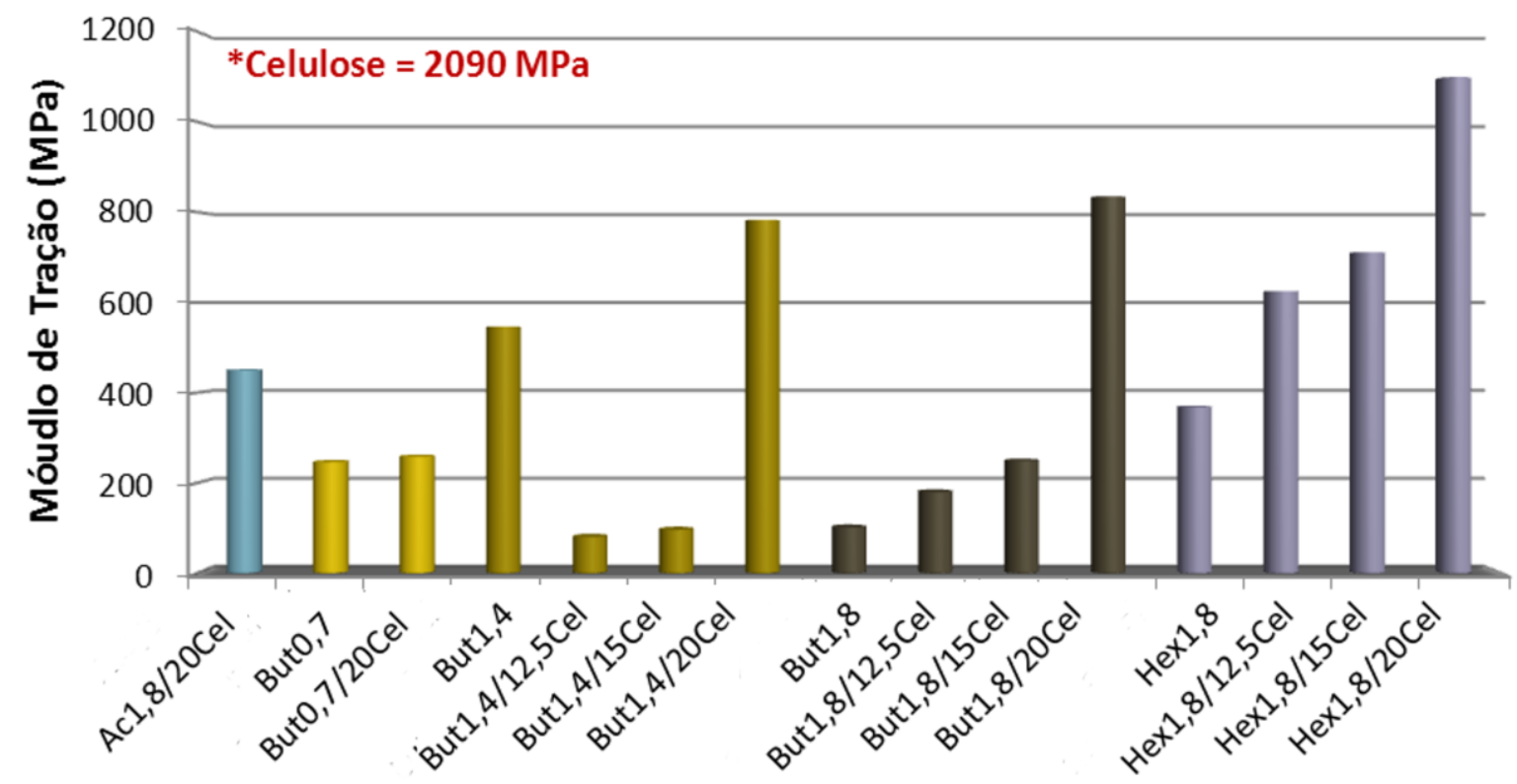

* valor não inserido no gráfico, em virtude da diferença de escala.

*os erros associados às medidas (triplicata) variaram em um intervalo entre 4-6\%.

Observa-se que, assim como para a análise de DMA, os ensaios de tração mostram resultados muito superiores para o filme de celulose. Isso é possivelmente justificado pela razão de as cadeias de celulose serem mais firmemente ligada, devido à maior presença de hidroxilas, que promovem fortes interações, devido à realização de ligações hidrogênio. Entretanto, é válido observado que a introdução da celulose na composição dos filmes foi responsável, na maioria das vezes, por aumentar os valores de módulo de armazenamento, resistência à tração e módulo de tração, sendo assim um indicativo que a celulose atue como um agente de reforço polimérico. 


\section{Breve Sumário e Conclusões Parciais}

Nesta etapa do trabalho, diferentes filmes e biocompósitos (reforço com celulose de sisal) foram preparados, a partir dos ésteres de celulose de sisal preparados em meio homogêneo (etapa anterior). As imagens de MEV para a superfície de ruptura dos biocompósitos revelou a presença de estruturas fibrosas, sugerindo agregação da celulose durante o processo de dissolução e/ou preparação dos filmes e consequente permanência após a eliminação do solvente. A presença destas estruturas fibrosas pode ser considerada um indicativo da possibilidade de a celulose agir como um agente de reforço nas matrizes dos ésteres de celulose. Nesta direção, os resultados de DMA e ensaios de tração revelaram que, de modo geral, a introdução de celulose levou a biocompósitos com propriedades melhores, em relação aos filmes sem reforço. Foram obtidos resultados superiores de módulo de armazenamento e resistência à tração, com a consequente obtenção de materiais com superiores valores de Módulo de Tração (mais rígidos) e menor alongamento na ruptura. Filmes de butanoato de celulose (GS I,8) com $20 \%$ de celulose mostraram valores de módulo de armazenamento (675 $\mathrm{MPa}$ ) quase 4x maiores que o mesmo filme sem reforço (195 MPa). Para os filmes a partir de hexanoatos de celulose (GS I,8), a adição de celulose (I5\%) mostrou aumentar a resistência a tração em até I unidade, em relação ao filme sem reforço. 


\section{CAP 3. FILMES DE ÉSTERES DE CELULOSE E CELULOSE DE SISAL: ESTUDOS DE SUPERFÍCIE UTILIZANDO XPS, TOF-SIMS E ÂNGULO DE CONTATO}

Neste capítulo foi abordado o estudo das superfícies dos filmes preparados a partir de ésteres de celulose de sisal e celulose de sisal, conforme descrito no Capítulo 2. Para tal, foram consideradas técnicas de caracterização não rotineiras, como XPS e ToF-SIMS, visando um estudo detalhado. Adicionalmente, os filmes foram avaliados quanto ao ângulo de contato da superfície com uma gota de água. Os filmes e biocompósitos analisados foram selecionados de forma que as análises de superfície permitissem correlacionar efeitos relacionados à mudança de GS em filmes preparados a partir de um mesmo tipo de cadeia lateral (butanoatos de diferentes GS), assim como efeitos relacionados à mudança do tipo de cadeia lateral (acetato; butanoato e hexanoatos) em um mesmo GS $(1,8)$. O efeito da adição de celulose (20\%) foi avaliado em filmes de ésteres com diferentes cadeias laterais (acetato; butanoato e hexanoatos) e de mesmo GS $(1,8)$.

\section{Introdução}

\section{I.I Técnicas de Microscopia}

A morfologia e a composição química da superfície de materiais podem ser estudadas por meio de técnicas de microscopia química. Neste campo são compreendidas inúmeras técnicas, as quais podem avaliar a composição química em escalas que variam de micrômetros a nanômetros, inferior a resolução de poucos átomos. Estas técnicas podem ser divididas em técnicas espectroscopias e espectrométricas, detectando imagens ou elementos e energias, respectivamente.

As seções a seguir apresentarão algumas informações relevantes, relativas a algumas das técnicas de microscopia utilizadas ao longo deste estudo, compreendendo: 
- FE-SEM (Field Emission Scanning Electron Microscopy) - Microscopia de Varredura Eletrônica por Emissão de Campo

- XPS (X-ray Photoelectron Spectroscopy) - Espectroscopia fotoeletrônica de raios X

- ToF-SIMS (Time-of-Flight Secondary lon Mass Spectroscopy) - Espectroscopia de massa de íons secundários por tempo de vôo.

XPS e ToF-SIMS são importantes técnicas para avaliação de materiais, pois fornecem informações da composição em escalas de poucos nanômetros, a qual corresponde ao intervalo das forças intermoleculares interfaciais. Para comparação, algumas das técnicas usualmente empregadas para a caracterização da superfície química são sumarizadas na Tabela I2 (KINGSHOTT et al., 20II).

Tabela 12 - Métodos de análise para caracterização química da superfície de materiais (KINGSHOTT et al., 20I I).

\begin{tabular}{|c|c|c|}
\hline Técnica & Resolução & $\begin{array}{c}\text { Informações obtidas } \\
\text { SIMS-Estático }\end{array}$ \\
\hline XPS & $<5 \mathrm{~nm}$ & $\begin{array}{r}\text { Química; fragmentos moleculares possibilitam a } \\
\text { obtenção de informações estruturais. }\end{array}$ \\
\hline MIES* & $2-10 \mathrm{~nm}$ & Elementar, Química (Quantitativa). \\
\hline Ângulo de Contato & $<\mathrm{Inm}$ & Química, estrutural, eletrônica. \\
\hline Elipsometria & $300 \mathrm{~nm}$ & Espessura de revestimento, cinética de adsorção. \\
\hline SFA** & $\mu \mathrm{m}$ & Química, conformacional, estrutural. \\
\hline
\end{tabular}

* MIES: Metastable Induced Electron Spectroscopy

** SFA: Surface Force Apparatus

\section{I.2 Microscopia Eletrônica de Varredura por}

\section{Emissão de Campo}

A Microscopia Eletrônica de Varredura por Emissão de Campo (FE-SEM) fornece imagens topográficas de superfícies, com a emissão de campo fornecendo ampla profundidade de campo, aumentando a percepção tridimensional e resolução em comparação às micrografias obtidas por SEM. Mapeamento de elementos também pode ser 
realizado, quando combinado análise de raios $X$ por dispersão de energia (EDX) com SEM. $A$ resolução espacial é de aproximadamente I $\mu \mathrm{m}$ para o mapeamento e aproximadamente 2 $\mathrm{nm}$ para imagem, e a profundidade de análise é da ordem de um micrômetro. A varredura eletrônica é realizada no vácuo e a superfície, como é varrida por elétrons, tem que ser condutora para impedir carga elétrica e aquecimento. Materiais isolantes, como polpas, fibras, filmes de polímeros derivados de celulose e seus ésteres, por exemplo, necessitam ser recobertas por uma camada condutora, procedimento usualmente realizado com ouro, ouro/paládio ou carbono (utilizado neste trabalho). A Figura 53 ilustra o princípio de funcionamento da técnica de FE-SEM.

Figura 53 - Esquema adaptado do princípio de funcionamento de FE-SEM (adaptado de http://infohost.nmt.edu/ mtls/instruments/Fesem/FESEM\%20principle.gif).

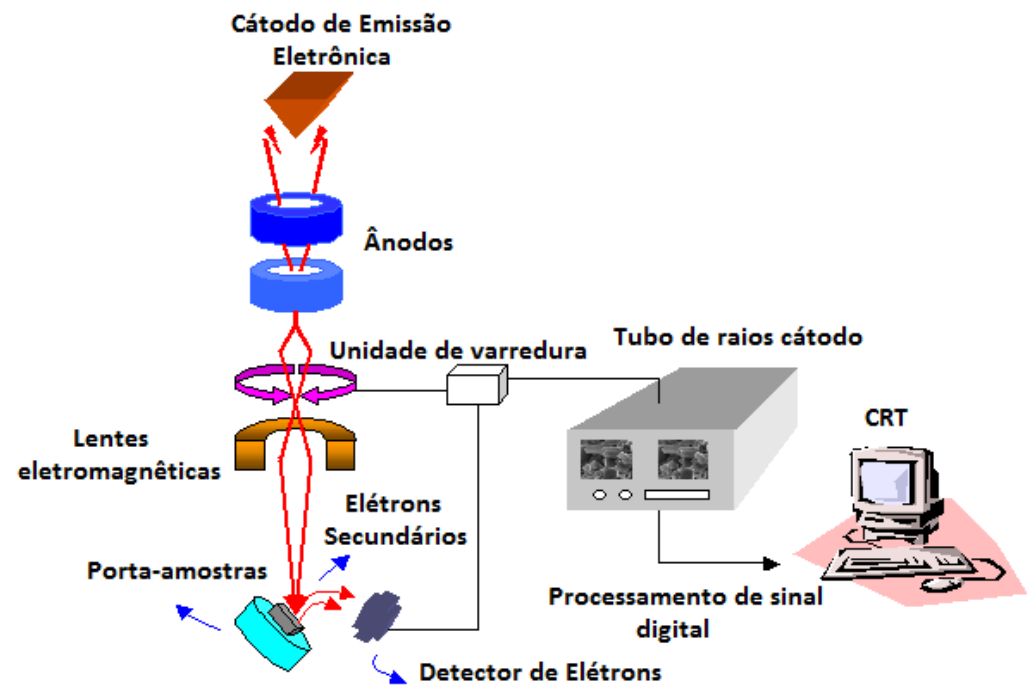

No presente trabalho, a técnica de FE-SEM foi utilizada para a obtenção de micrografias das superfícies dos filmes/biocompósitos preparados a partir de ésteres de celulose de sisal/celulose de sisal, assim como do filme de celulose, para posterior análise morfológica. 


\section{I.3 XPS (X-ray Photoelectron Spectroscopy)}

A técnica de XPS é uma importante ferramenta para determinação de elementos de superfície (com exceção de $\mathrm{H}$ e He). $\mathrm{O}$ princípio da técnica é baseado na medida da energia cinética dos fotoelétrons ejetados de uma superfície sólida, quando esta é bombardeada com raios $\mathrm{X}$ de alta energia em um vácuo ultra alto. $\mathrm{O}$ bombardeamento cria átomos ionizados na amostra, ejetando elétrons livres, os quais possuem suas energias cinéticas relacionadas às suas energias de ligação no átomo original. A resolução espacial da técnica de XPS é de aproximadamente $100 \mathrm{~mm}$, com uma profundidade de análise na ordem de $3-10 \mathrm{~nm}$, dependendo da topografia e inclinação da amostra. A Figura 54 ilustra o princípio de funcionamento da técnica de XPS.

Figura 54 - Princípio de funcionamento da técnica de XPS (adaptado de http://home.iiserbhopal.ac.in/ rssingh/pics/ARPES.png).

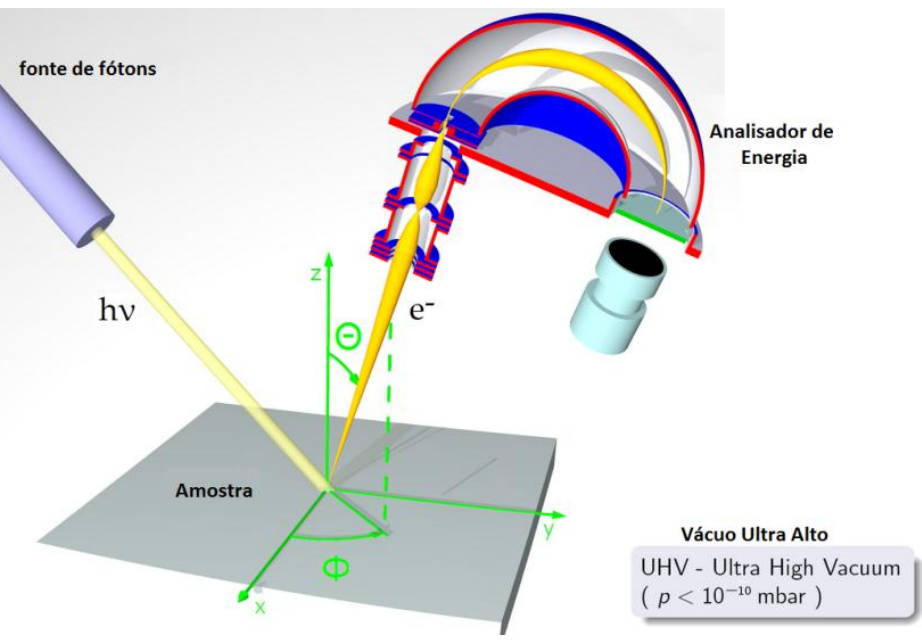

A análise XPS fornece informações sobre a composição química e ligações químicas da superfície sólida. Durante a análise de XPS, uma amostra é iluminada com uma luz monocromática de raios $\mathrm{X}$ e as energias dos fotoelétrons emitidos da amostra são analisadas. No espectro de fotoelétrons, o qual apresenta a distribuição dos fotoelétrons emitidos como uma função de suas energias de ligação, picos podem ser observados, os quais são típicos de elementos presentes na superfície da amostra. Por meio da forma e energia de ligação dos picos contidos no espectro de XPS, a ligação química de elementos da 
superfície pode ser identificada com o auxílio de dados contidos na literatura. Por exemplo, no caso de materiais orgânicos, pode-se identificar através do espectro de carbono $\mathrm{Cls}$ (energia de 282-297 eV), ligações de átomos de carbono como C-C/C-H, C-O, C=O, C-N, O-C-O, O=C-O, C-F, entre outros (KOVAČ, 20II; GUEZGUEZ; MRABET; FERJANI, 20I3).

\section{I.4 ToF-SIMS}

SIMS consiste numa técnica analítica para a análise composicional de superfícies de sólidos e filmes finos (VICKERMAN, 2009). Está técnica é baseada na coleta de espectros de massa de íons positivos ou negativos, os quais são criados na superfície da amostra quando esta é bombardeada com partículas primárias pesadas. Assim, os dados coletados são restritos a mais extrema camada de moléculas na superfície da amostra, com alta sensibilidade química, no intervalo de PPB. Devido a sua habilidade na identificação de estruturas moleculares, isto é, tipos de moléculas na superfície, a técnica de SIMS tem sido extensivamente aplicada em análises de polímeros (VICKERMAN, 2009; ORBLIN; ETA; FARDIM, 20II; CHIA; BOULANGER; LAPIERRE, 20I3). Durante a análise de SIMS, a superfície do polímero/filme é bombardeada com feixes de íons de alta energia ( I-30 keV), o que resulta na injeção ou no "sputtering" de espécies da superfície do sólido. A maioria das partículas emitidas é neutra, mas uma pequena fração destas consiste em íons carregados, os quais são chamados de íons secundários. Os analisadores de massa mais comuns são: (I) analisador de massa quadrupolar (2) analisador de massa com setor magnético e (3) analisador por tempo de vôo (TOF). Eles diferem quanto à transmissão, resolução de massa, detecção de massa, dentre outros aspectos. Entre estes, o ToF-SIMS é o que fornece a maior sensibilidade, resolução e faixa de massas (KOVAČ, 20II). A Figura 55 ilustra o princípio de funcionamento da técnica de ToF-SIMS. 
Figura 55 - Princípio de funcionamento da técnica de ToF-SIMS (adaptado de http://www.phi.com/images/techniques/tof-sims/SIMS-process.gif).

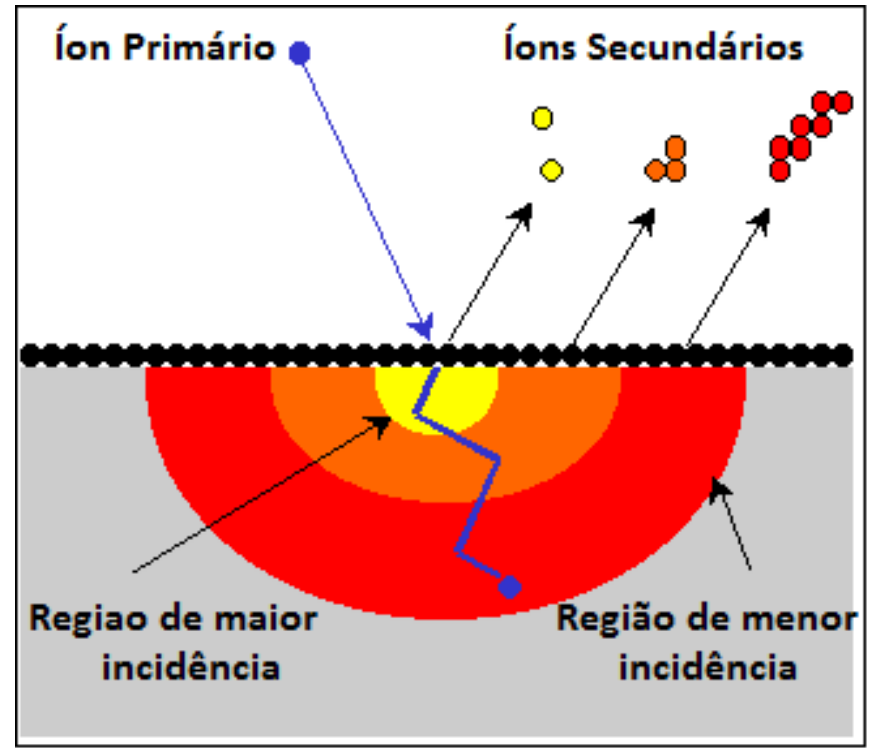

A técnica de ToF-SIMS tem sido extensivamente utilizada ao longo da última década em diversas áreas, dentro da orgânica e inorgânica. Como exemplo, pode-se citar estudos envolvendo detecção de atividade enzimática em substratos sólidos da madeira (GOACHER et al., 20I2), a fragmentação de lignina (SAITO; KATO; TAKAMORI; et al., 2005; SAITO; KATO; TSUJl; et al., 2005), pectina (TOKAREVA; PRANOVICH; HOLMBOM, 20I I), como também em estudos visando mapear a distribuição de componentes da madeira (TOKAREVA; FARDIM; et al., 2007; TOKAREVA; PRANOVICH; et al., 2007) e distribuições espaciais e laterais de componentes de biopolímeros na biomassa (JUNG et al., 20I2).

\section{I.5 XPS e ToF-SIMS como técnicas complementares}

Um avanço importante referente às técnicas de XPS e ToF-SIMS vem ocorrendo devido ao desenvolvimento de novos softwares de imagens, altamente capacitados, capazes de fornecer imagens da distribuição espacial da superfície química, tornando-se assim uma tecnologia essencial para estudos de materiais, como os considerados no presente projeto. 
A técnica de XPS pode se aliar à técnica de ToF-SIMS, oferecendo uma poderosa ferramenta na análise das fibras celulósicas, modificadas e não modificadas. De uma maneira simplificada, em uma análise XPS, carbono e oxigênio são os principais elementos detectados na análise de fibras celulósicas e fibras celulósicas esterificadas, como seria de se esperar. A desconvolução em alta resolução destes espectros de XPS, especificamente do pico $\mathrm{Cls}$, é responsável por fornecer as áreas relativas de $\mathrm{Cl}(\mathrm{C}-\mathrm{H}, \mathrm{C}-\mathrm{C}), \mathrm{C} 2(\mathrm{C}-\mathrm{O}), \mathrm{C} 3$ (O-C-O ou $\mathrm{C}=\mathrm{O})$ e $C 4(\mathrm{O}-\mathrm{C}=\mathrm{O})$. O decréscimo na razão $\mathrm{O} / \mathrm{C}$ e o correspondente aumento na contribuição dos carbonos $\mathrm{Cl}$ (C-C e C-H) seguidos das reações de esterificação, podendo indicar a ocorrência da esperada modificação das cadeias celulósicas. Assim, por meio desta técnica, e usando a matemática adequada, pode-se estimar a cobertura da superfície ( $\Theta f a)$ das fibras pelos grupos ésteres (\%), usando-se as áreas relativas de $C /$ (C-C, C-H) (FREIRE, CARMEN S. R. et al., 2006).

Então, o valor de $\mathrm{Cl}$ refletirá a extensão da cobertura da superfície das fibras pelo agente de modificação, neste caso, pelas cadeias dos grupos ésteres. Esta contribuição de $\mathrm{Cl}$ deve ser vista como uma combinação do (I) comprimento da cadeia do éster e (2) grau de substituição deste (FREIRE, CARMEN S. R. et al., 2006).

Assim, por meio desta técnica, no presente projeto, foram obtidas importantes relações entre o grau de cobertura da superfície, e relações entre $\circ$ grau de cobertura de diferentes ésteres com mesmo GS ou de um grupo de um mesmo éster, com diferentes GS. Este estudo, realizado em filmes/biocompósitos de ésteres de celulose/celulose de sisal, é pioneiro e importante para o entendimento de como se dá a distribuição destes grupos ésteres pela superfície dos filmes, contribuindo para o entendimento da dependência desta distribuição com o tamanho da cadeia do éster, GS e com a presença da celulose nos biocompósitos e, consequentemente, com as propriedades destes filmes. 


\section{Experimental}

Diferentes filmes/biocompósitos a partir de acetatos, butanoatos e hexanoatos de celulose foram selecionados para as análises de superfície (FE-SEM, XPS e ToF-SIMS) e estão sumarizados na Tabela 13.

Ressalta-se que todos os filmes e biocompósitos utilizados nesse estudo foram preparados com extrema cautela, evitando-se o contato com plásticos ou qualquer outra fonte de contaminantes durante a preparação ou armazenamento. Desde que as técnicas de XPS e ToF-SIMS são conhecidas pela alta sensibilidade de detecção, optou-se por não utilizar os filmes/biocompósitos análogos, preparados anteriormente (Capítulo 2), os quais eram armazenados em plásticos de polietileno. A armazenagem da maneira como era feita poderia ser responsável pela contaminação da superfície com siloxanos. Embora a armazenagem tenha ocorrido de forma diferente (entre folhas de alumínio), o método de preparação seguiu procedimentos idênticos aos descritos no Capítulo 2.

Tabela I3 - Filmes/biocompósitos considerados no presente projeto.

\begin{tabular}{|c|c|c|c|c|}
\hline Filme/Biocompósito & & Análise & & Sigla \\
\hline & FE-SEM & XPS & ToF-SIMS & \\
\hline Ac. GS I,8 & X & $x$ & $\mathrm{X}$ & Ac. I,8 \\
\hline Ac. GS I,8/20\% cel. & $x$ & $x$ & & Acl,8/20cel. \\
\hline But. GS 0,7 & $x$ & 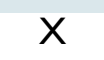 & & But0,7 \\
\hline But. GS I,4 & $x$ & $x$ & & But I,4 \\
\hline But. GS I,8 & $x$ & $x$ & $\mathrm{x}$ & But I,8 \\
\hline But. GS I,8/20\% cel. & $x$ & $x$ & & Butl,8/20cel. \\
\hline Hex. GS I,8 & $x$ & $x$ & $\mathrm{X}$ & HexI,8 \\
\hline Hex. GS I,8/20\% cel. & $x$ & $x$ & $x$ & HexI,8/20cel. \\
\hline Filme de Celulose & $x$ & $X$ & $\mathrm{X}$ & Cel. \\
\hline
\end{tabular}

Os filmes e biocompósitos sumariados na Tabela 13 foram escolhidos tendo-se como perspectiva que as análises de superfície permitissem correlacionar efeitos relacionados à mudança de GS em diferentes filmes a partir de um mesmo tipo de cadeia lateral (acetatos e butanoatos de diferentes GS), assim como efeitos relacionados à mudança do tipo de cadeia 
lateral (acetato; butanoato e hexanoatos) em um mesmo GS $(I, 8)$. $\bigcirc$ efeito da adição de celulose (20\%) foi estudado em filmes de ésteres com diferentes cadeias laterais e de mesmo GS $(1,8)$.

\section{I XPS}

Para o período de Setembro/20I2 à Fevereiro/2013, o aluno foi contemplado com uma Bolsa de Estágio de Pesquisa no Exterior (BEPE/FAPESP - Processo n 2012-008I3-9), onde desenvolveu um trabalho de colaboração com a Åbo Akademi University (Turku, Finlândia), sob supervisão do Prof. Dr. Pedro Fardim. As análises de XPS e ToF-SIMS (Seção 2.2) foram realizadas durante este estágio.

Para as análises de XPS e ToF-SIMS, as amostras dos biocompósitos foram previamente extraídas em Soxhlet, em um sistema de solvente acetona/água (9:1) por 4h. Esta extração foi realizada visando à remoção de possíveis contaminantes nas superfícies dos filmes/biocompósitos, principalmente $\mathrm{Si}$, comumente encontrado como impureza em amostras de celulose e derivados. A presença em grande quantidade destes contaminantes, em especial Si, poderia ser prejudicial às análises, levando a interpretações equivocadas ou mesmo inviabilizando a realização destas.

As medidas de XPS foram realizadas com auxílio de um Espectrômetro PHI Quantum 2000 equipado com uma fonte monocromática de raios $X \mathrm{AIK} \alpha$, operada a $25 \mathrm{~W}$ e com uma combinação de canhão de corrente de elétrons e bombardeio de íons, para compensação de carga. Os fotoelétrons foram coletados em uma área de $300 \mu \mathrm{m} \times 200 \mu \mathrm{m}$, com energia de $18785 \mathrm{eV}$ para varredura ampla (3,5 min), e 23,5 eV para varreduras de alta resolução para $\mathrm{Cls}$ (9 $\mathrm{min})$. As medidas foram realizadas em quatro diferentes pontos em cada amostra. Uma amostra extraída de papel de filtro de fibras celulósicas (livre de cinzas) foi considerada como uma referência interna para celulose, nas medidas de XPS. As razões O/C foram obtidas dos espectros de XPS de baixa resolução. Os espectros de alta resolução de $\mathrm{Cl}$ s foram desconvoluídos para curvas parciais de $\mathrm{Cl}, \mathrm{C2}, \mathrm{C} 3$ e C4, por meio do software provido pela fabricante do instrumento. As seguintes energias de ligação 
relativas à posição de $\mathrm{C}-\mathrm{C}$ (i.e., $\mathrm{Cl}$ ) foram empregadas nos respectivos grupos: $1,7 \pm 0,2 \mathrm{eV}$ para C-O (C2), 3, I $\pm 0,3 \mathrm{eV}$ para $\mathrm{C}=\mathrm{O}(\mathrm{C} 3)$ e 4,6 $\pm 0,3 \mathrm{eV}$ para $\mathrm{O}=\mathrm{C}-\mathrm{O}(\mathrm{C} 4)$.

\subsection{ToF-SIMS}

O equipamento de ToF-SIMS utilizado foi um Physical Electronics PHI TRIFT II. As medidas foram realizadas utilizando um feixe de íon metálico de ${ }^{69} \mathrm{Ga}^{+}$com $25 \mathrm{keV}$ sobre o intervalo de passa de 2-4000 Da, em modo positivo e negativo. Assim, priorizou-se a obtenção de imagem em resolução ótima em detrimento da resolução do pico. A área de superfície excitada foi de $200 \mu \mathrm{m} \times 200 \mu \mathrm{m}$ e, em adição, uma varredura de imagens ToFSIMS foi realizada em uma área de varredura de $100 \mu \mathrm{m} \times 100 \mu \mathrm{m}$. $O$ tempo de aquisição para cada varredura foi de $8 \mathrm{~min}$. A compensação de carga foi realizada usando-se um canhão com fluxo de elétrons pulsados fora de fase com um canhão de íon. Para cada amostra, pelo menos três diferentes áreas foram consideradas para a obtenção de dados.

\section{3 Ângulo de Contato}

O ângulo de contato dinâmico entre a uma gota de água desionizada e a superfície dos filmes/biocompósitos foi medido (TAPPI, 1994). Um equipamento de ângulo de contato modelo CAM 2008 (KSV), equipado com uma câmera e um sistema de gravação, foi usado (Instituto de Física de São Carlos, IFSC/USP) para as medidas. Uma gota de água deionizada (3 $\mu \mathrm{L}$ ) foi depositada sobre a superfície de cada filme/biocompósito e a variação do ângulo de contato foi calculada a partir de 300 medidas, realizada em triplicada (usando três regiões distintas). 


\section{Resultados e Discussão}

\section{I XPS}

As composições elementares dos filmes e biocompósitos foram detectadas via espectros de XPS. A desconvolução de alta resolução do pico $\mathrm{Cl}$ foi responsável em fornecer as áreas relativas de of $\mathrm{Cl}(\mathrm{C}-\mathrm{H}, \mathrm{C}-\mathrm{C}), \mathrm{C} 2(\mathrm{C}-\mathrm{O}), \mathrm{C} 3(\mathrm{O}-\mathrm{C}-\mathrm{O}$ ou $\mathrm{C}=\mathrm{O})$ e $\mathrm{C} 4(\mathrm{O}-$ $\mathrm{C}=\mathrm{O})$.

Em adição aos constituintes moleculares dos derivados de celulose ( $C$ e $O)$, pequenas quantidades de $\mathrm{Si}(0.3-1.6 \%)$ foram detectadas em algumas amostras (com exceção dos filmes de butanoatos com GS 0,7 e I,4), mesmo após cuidadosa preparação das amostras, evitando contatos com plásticos (preparação e armazenamento) ou outras fontes de siloxano. A presença de Si em plantas é usualmente atribuída a uma autoproteção destas em relação ao ambiente externo. Enquanto árvores usam casca como proteção, plantas anuais geram sílica, a qual age como uma película externa. Plantas não madeireiras geralmente exibem um maior teor de cinzas que a madeira por si só; a madeira contém sílica como um constituinte primário, embora diferentes plantas exibam uma vasta gama de variação, tanto no teor de cinzas quanto no teor de sílica (EPSTEIN, 200I).

Para algumas plantas, como o sisal, o teor total de cinzas é baixo e comparável à madeira $(<1 \%)$. O teor total de sílica é insignificante na madeira e somente um pouco maior que no sisal. $\mathrm{O}$ teor de sílica $\left(\mathrm{SiO}_{2}\right)$ em fibras de sisal foi gravimetricamente reportado por SIBANI et al. (20I2) como estando na faixa de $0,33-0,47 \%$. Portanto, neste estudo, a origem da sílica deveu-se majoritariamente à presença desta no material de partida. Reforçando esta hipótese, tem-se que silicatos de sódio são amplamente empregados no processamento de polpas, como por exemplo, antiespumantes. A polpa de sisal utilizada neste trabalho foi delignificada por meio do processo Kraft (“Elemental Chlorine-Free’), consistindo de uma sequência de branqueamento livre de cloro (LACERDA; ZAMBON; FROLLINI, 20I3). Entretanto, sabe-se que normalmente sais de magnésio e silicatos de sódio também podem ser adicionados para ajudar no branqueamento com peróxido alcalino, em processos mecânicos, o que também pode ter acontecido no presente caso. 
O filme de celulose como tal (Cel) diferiu um pouco da amostra de referência de celulose (papel de filtro livre de cinzas), apresentando uma menor razão $\mathrm{O} / \mathrm{C}(0,73 \rightarrow 6,5 \%$ menor), traços de $\mathrm{Si}$, assim como um maior conteúdo de $\mathrm{Cl}$ (14,9 $\rightarrow 30 \%$ maior) e um menor conteúdo de C2 (53,8 $\rightarrow$ 5\% menor, obtido via espectros de XPS de alta resolução), com referência às impurezas não celulósicas presentes na superfície das amostras.

Para os filmes de ésteres de celulose, tendências podem ser observadas nas razões $\mathrm{O} / \mathrm{C}$ e nos conteúdos de $\mathrm{Cl}$ seguindo a estrutura química da cadeia lateral e o GS. As cadeias laterais estão localizadas nas zonas de superfície dos filmes detectadas por XPS (Figura 56), com um aumento da contribuição de $\mathrm{Cl}$ conforme o aumento do GS para um mesmo tipo de grupo lateral (butanoato) e a razão $\mathrm{O} / \mathrm{C}$ diminuindo, indicando a esperada modificação das fibras de celulose (Figura 57).

Figura 56 - Representação esquemática da superfície dos filmes e a área detectável via XPS.

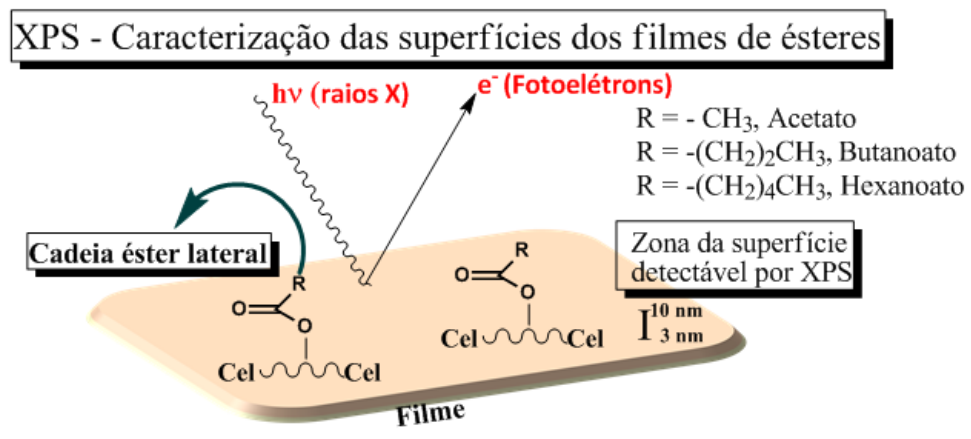

Figura 57 - Variação na (a) razão O/C e (b) Cl para os filmes de ésteres de celulose.
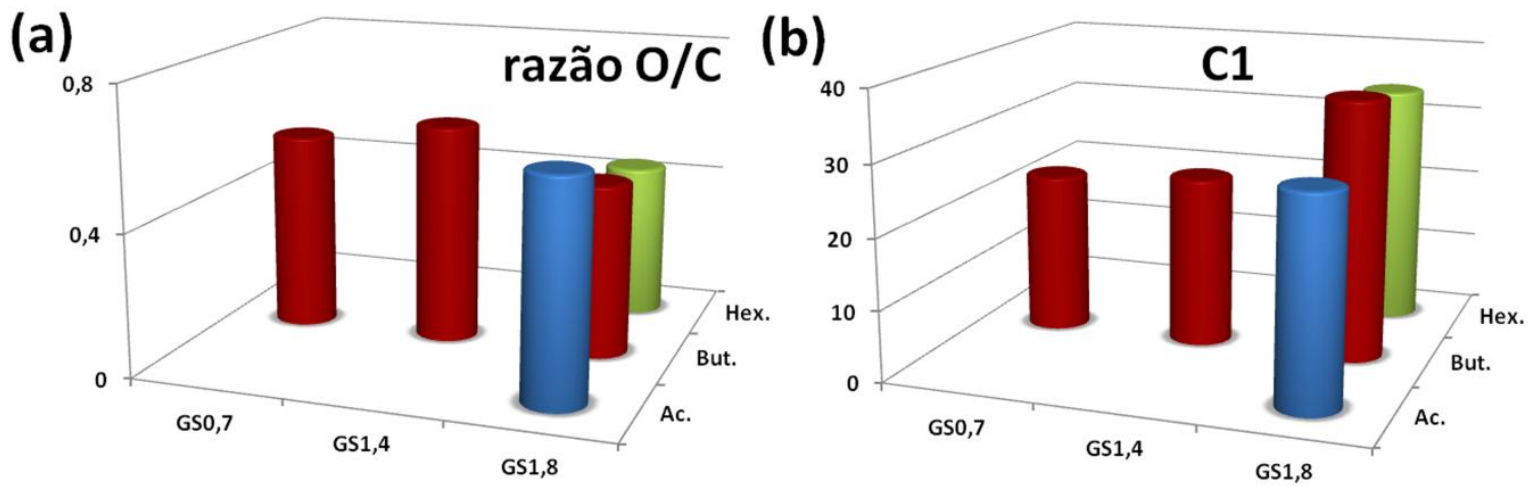

O conteúdo de $\mathrm{Cl}$ reflete a extensão da cobertura da superfície das fibras pelo agente de modificação, neste caso, pelas cadeias dos grupos ésteres. Esta contribuição de $\mathrm{Cl}$ 
deve ser vista como uma combinação do (I) comprimento da cadeia do éster e (2) grau de substituição deste (refletida pela densidade da cadeia lateral inserida). Ademais, as ligações ésteres dos derivados ésteres de celulose são detectados como contribuição em C4 nos espectros de XPS de alta resolução. Na celulose pura, o conteúdo de C4 seria teoricamente zero. Na prática, este não é o caso, e pequenas proporções de C4 são sempre detectadas devido à carga local de amostras isolantes causando ampliação de pico mesmo com a aplicação de carga neutralizante, ou devido a pequenas quantidades de contaminação ou mudanças químicas na estrutura da celulose (CARLSSON; STROEM, 1991). Nas amostras com mais $\mathrm{Cl}$, isto é, com maiores cadeias laterais (Butanoatos e Hexanoatos), o aumento detectado no conteúdo de C4 foi desprezível. Entretanto, em Ac. I.8, a influência da cadeia carbônica do éster pode ser observada nas medidas de XPS.

Nos biocompósitos, as razões O/C foram deslocados para valores superiores em relação aos filmes de referência (éster de mesmo GS, sem reforço), ao mesmo tempo em que decresceu com o aumento da cadeia (Ac > But > Hex), assim como esperado (Figura 58).

Figura 58 - Razões O/C para os filmes de ésteres de celulose e seus respectivos biocompósitos ( $20 \%$ de celulose).

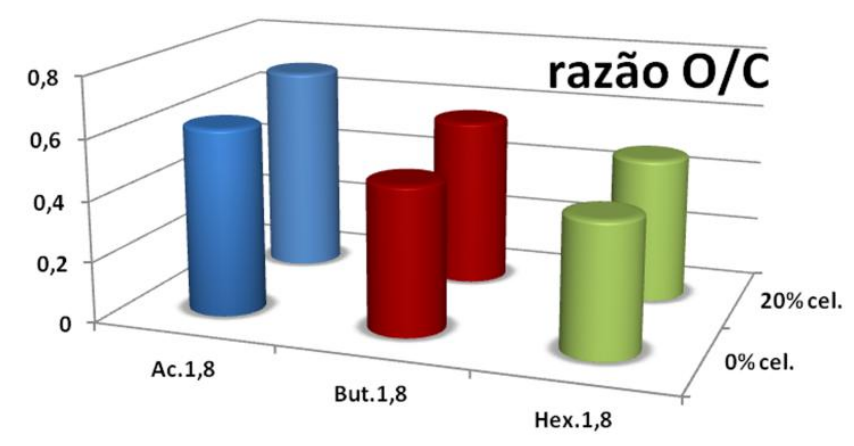

A tendência de aumento em $\mathrm{Cl}(\mathrm{Ac}$. $<$ But.<Hex.) e respectivo decréscimo em $\mathrm{C} 2$ foi ainda evidente com a adição de $20 \%$ de celulose aos biocompósitos (Figura 59). 
Figura 59 - Variação em Cl e C2 para os biocompósitos.

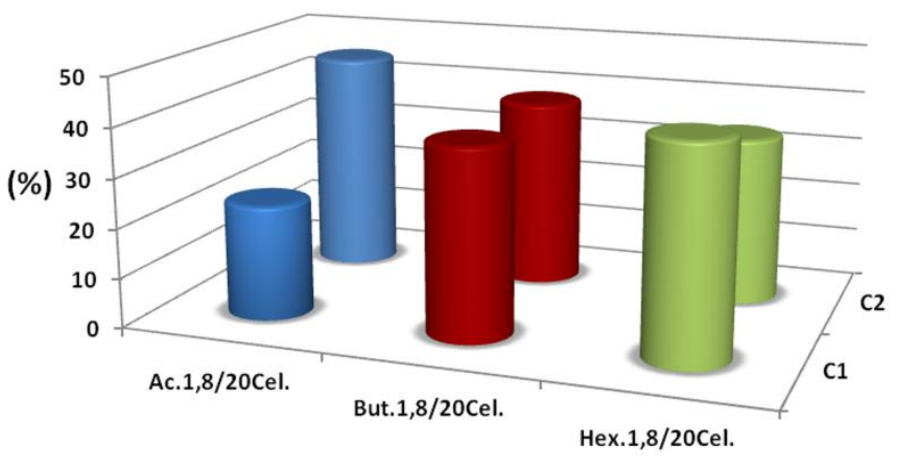

A cobertura superficial (\% $(f \mathrm{fa})$ por cadeias alifáticas dos grupos ésteres, nos filmes e biocompósitos, foi estimada por meio do uso da área relativa de $\mathrm{Cl}(\mathrm{C}-\mathrm{C}, \mathrm{C}-\mathrm{H})$, de acordo com a Equação 5.

$$
\% \theta \mathrm{fa}_{\mathrm{a}}=C \mathrm{FE}_{1}-C \mathrm{FCel} \quad \text { Eq. [5] }
$$

Sendo $\mathrm{CFE}_{1}$ e CFCel, as medidas de $\mathrm{Cl}$ nos filmes/biocompósitos e no filme de celulose (não modificado), respectivamente (FREIRE, CARMEN S. R. et al., 2006). A Figura 60 apresenta os resultados de cobertura superficial para os diferentes filmes de ésteres de celulose de diferentes GS.

Figura 60 - Cobertura superficial por cadeias alifáticas (grupos ésteres) para os filmes de butanoatos de celulose de diferentes GS e filmes de ésteres de celulose com diferentes tamanhos de cadeia (acetato; butanoato e hexanoato) com GS I,8.

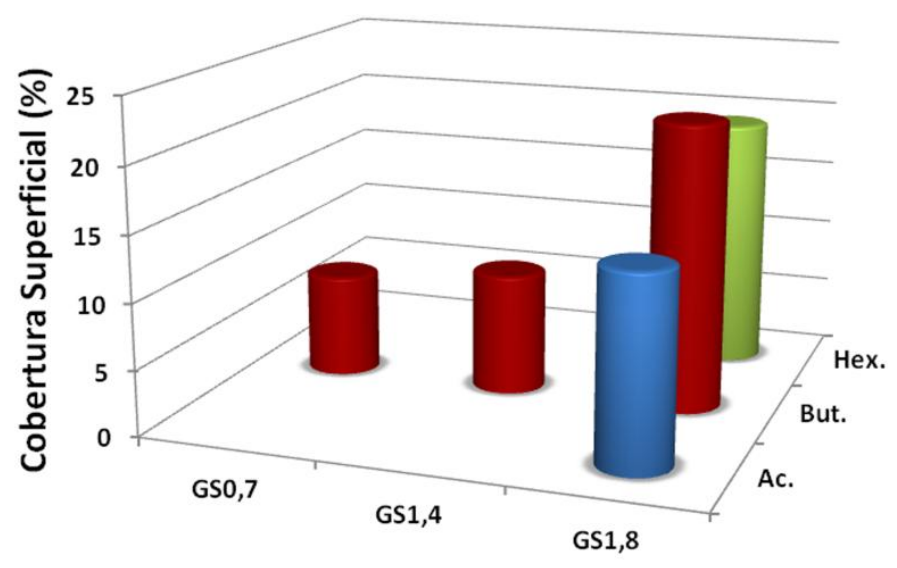

Analisando-se o gráfico (Figura 60), observa-se que a cobertura superficial dos filmes por cadeias alifáticas dos grupos ésteres, conforme esperado, aumenta com o aumento do 
GS para uma mesma cadeia (acetato e butanoato). Ademais, para um mesmo GS $(1,8)$ há uma tendência do aumento do valor de cobertura superficial, quando considerado o acetato em relação aos outros ésteres de cadeias superiores.

A Figura 61 apresenta a cobertura superficial para os diferentes filmes de ésteres de celulose (GS I,8) e seus respectivos biocompósitos ( $20 \%$ de celulose).

Figura 6I - Cobertura superficial por cadeias alifáticas (grupos ésteres) para os filmes de ésteres de celulose com GS I,8 e seus respectivos biocompósitos ( $20 \%$ de celulose).

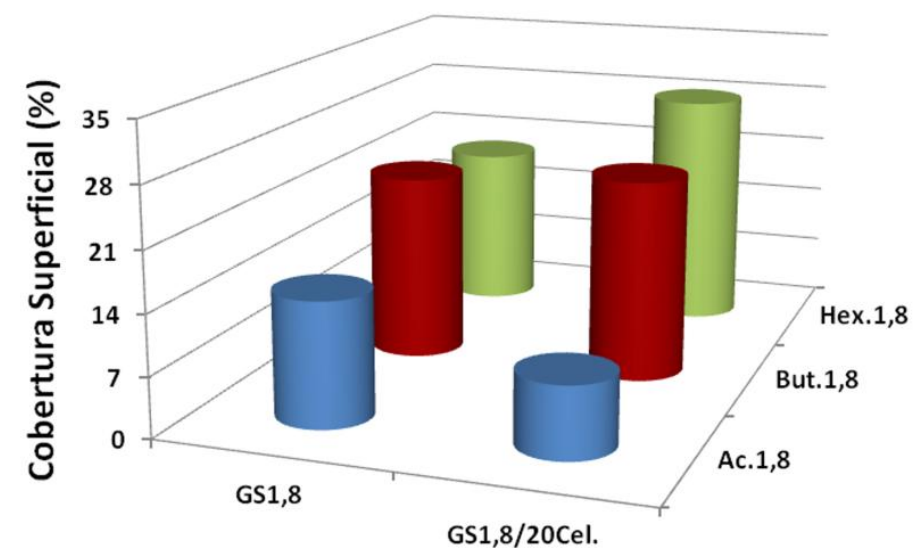

Analisando-se o gráfico (Figura 6I), observa-se que a cobertura superficial por cadeias alifáticas dos grupos ésteres, analisada em termos de $\mathrm{Cl}$, apresentou diferentes tendências. Comparando-se os filmes puros (GS I,8) com aqueles onde a celulose estava presente (GS I,8/20cel.), pode-se observar que o acetato de celulose, butanoato de celulose e hexanoato de celulose apresentaram, respectivamente, uma diminuição significativa $(42,4 \%)$, um ligeiro aumento $(8,2 \%)$ e um significante aumento $(45 \%)$ na cobertura superficial por cadeias ésteres. Este fato pode ser provavelmente atribuído à diferença de tamanhos das cadeias de ésteres consideradas. Conforme se aumenta o tamanho da cadeia do éster (Ac < But < Hex), também se aumenta o caráter hidrofóbico dos grupos ésteres, diminuindo gradualmente a afinidade com a celulose (altamente hidrofílica). Grupos mais hidrofóbicos tendem a se projetar para a superfície, o que é de fato observado com o aumento da cobertura superficial por cadeias ésteres conforme se aumenta o tamanho da cadeia éster considerada. A diminuição observada para o acetato de celulose na presença de celulose, em contraste com os ésteres de cadeias longas, demonstra a maior afinidade da celulose frente a esse grupo éster de menor volume, o que justificaria a maior presença de celulose em sua superfície. 


\subsection{ToF-SIMS}

Para as análises de ToF-SIMS, apenas o filme de celulose e os conjuntos de filmes (sem reforço) e biocompósitos preparados a partir de acetatos e hexanoatos de celulose de GS I,8 e $20 \%$ de celulose foram analisados

Nos espectros positivos de Acl,8, e menos intensamente nos espectros de Hexl,8, a impressão digital de poli (dimetilsiloxano) foi distinguida (picos 28, 73, 147, 191, 207, 222 e $282 \mathrm{Da}$ ). Este composto (derivado de Si) é uma contaminação típica em amostras celulósicas e esteve presente mesmo após cuidadosa preparação das amostras, evitando contatos com plásticos (preparação e armazenamento) ou outras fontes de siloxano. Por outro lado, os picos característicos de celulose, 127 e 145 Da (referência), foram também detectados, com uma razoável intensidade de pico.

O filme Acl,8 mostrou claramente um aumento na intensidade de pico do pico de massa $43\left(\mathrm{C}_{2} \mathrm{H}_{3} \mathrm{O}^{+}\right)$em modo de íon positivo. Este fragmento está presente em amostras celulósicas em geral, mas a acetilação aumentou a contagem em 360x quando comparado a Cel (intensidades normalizadas). Este resultado aponta que os grupos laterais estejam presentes na extremidade da superfície da amostra. $O$ pico de massa 43 foi escolhido para mapeamento de grupos acetatos na superfície da amostra em modo positivo de ionização [Figura 62-(a) e (b)].

Figura 62 - Distribuições de grupos acetato (a) e (b) e hexanoatos (c) e (d) nas amostras Acl,8 e Hexl,8, em modo positivo. Imagens de íons totais. Área varrida: 200x $200 \mu \mathrm{m}^{2}$ (a) e (c) e $100 \times 100 \mu m^{2}$ (b) e (d).
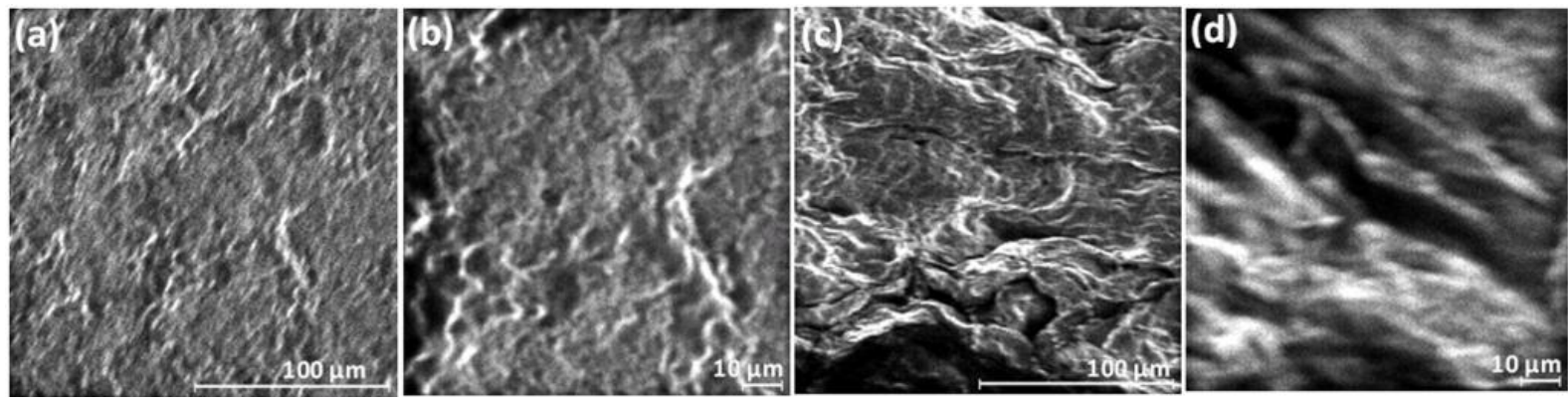
O sinal de fragmento de acetato é visto como um aumento no brilho das imagens no pixel em questão [Figura 62-(a) e (b)]. Parte das diferenças de intensidade é devida a efeitos topográficos, os quais podem ser previstos na imagem de íon total. A distribuição detectada de grupos acetatos foi razoavelmente uniforme na escala investigada.

O espectro de massa positivo para o filme Hexl,8 mostrou um pico de massa eminente em $99 \mathrm{Da}$, o qual não foi detectado em Cel. Experimentalmente, esse pico de massa supostamente representaria o fragmento $\mathrm{C}_{6} \mathrm{H}_{11} \mathrm{O}^{+}$, originado do hexanoato de celulose por meio da clivagem da ligação éster. A distribuição do pico 99 é apresentada na Figura 62-(c) e (d). Aparentemente, os grupos hexanoatos estão homogeneamente presentes na superfície.

Em modo de íon negativo, estes fragmentos também contiveram o oxigênio etérico $(\mathrm{O}-\mathrm{C}=\mathrm{O})$, e os picos foram intensos em ambos Ac. I,8 (m/z 59, $\left.\mathrm{C}_{2} \mathrm{H}_{3} \mathrm{O}_{2}\right)$ e em Hex.l,8 (m/z II $\left.5, \mathrm{C}_{6} \mathrm{H}_{11}\right)$, vide Figura 63.

Figura 63 - Espectros de massa ToF-SIMS de íons negativos no intervalo de 30-I30 Da para os filmes Acl,8 e HexI,8, coletados em uma área de varredura de $200 \times 200 \mu \mathrm{m}^{2}$.
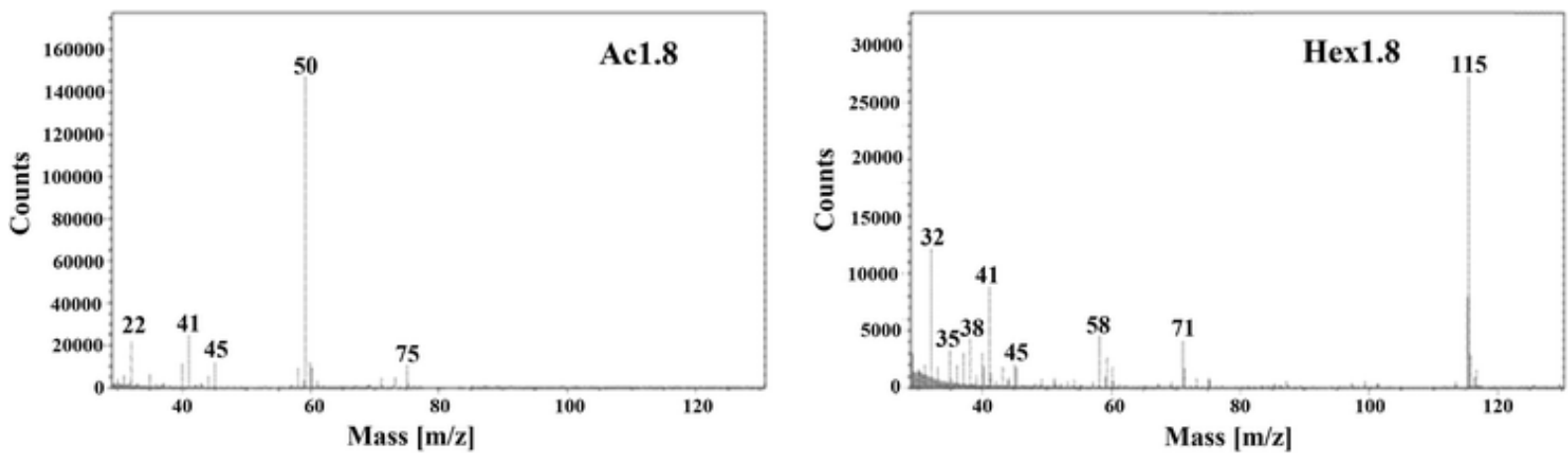

Os mapas de distribuição foram realizados também para o modo negativo, e uma similar distribuição foi encontrada, como observado nas imagens de íons positivos (Figura 64). 
Figura 64 - Distribuições de grupos acetato (a) e (b) e hexanoatos (c) e (d) nas amostras $\mathrm{Acl}, 8$ e Hexl,8, em modo negativo. Imagens de íons totais. Área varrida: 200x $200 \mu \mathrm{m}^{2}$.
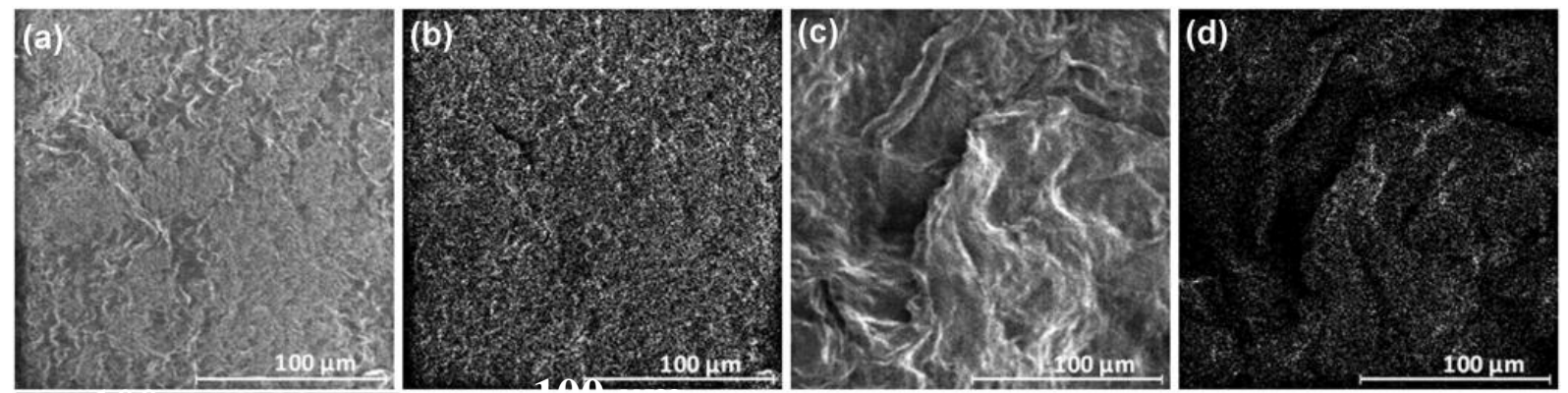

Para os biocompósitos (com celulose adicionada, $20 \%$ em massa), foram obtidos espectros de ToF-SIMS qualitativamente similares aos filmes preparados apenas com o éster de celulose ( $0 \%$ de celulose). A distribuição dos grupos hexanoatos em HexI,8/20Cel é mostrada na Figura 65, em modo positivo e negativo.

Figura 65 - Distribuições de grupos hexanoatos em Hexl,8/20Cel, mapeando o íon positivo $99 \mathrm{Da}$ (imagem de íons totais). Área varrida: $200 \times 200 \mu \mathrm{m}^{2}$ (a) e $100 \times 100 \mu \mathrm{m}^{2}$ (b).

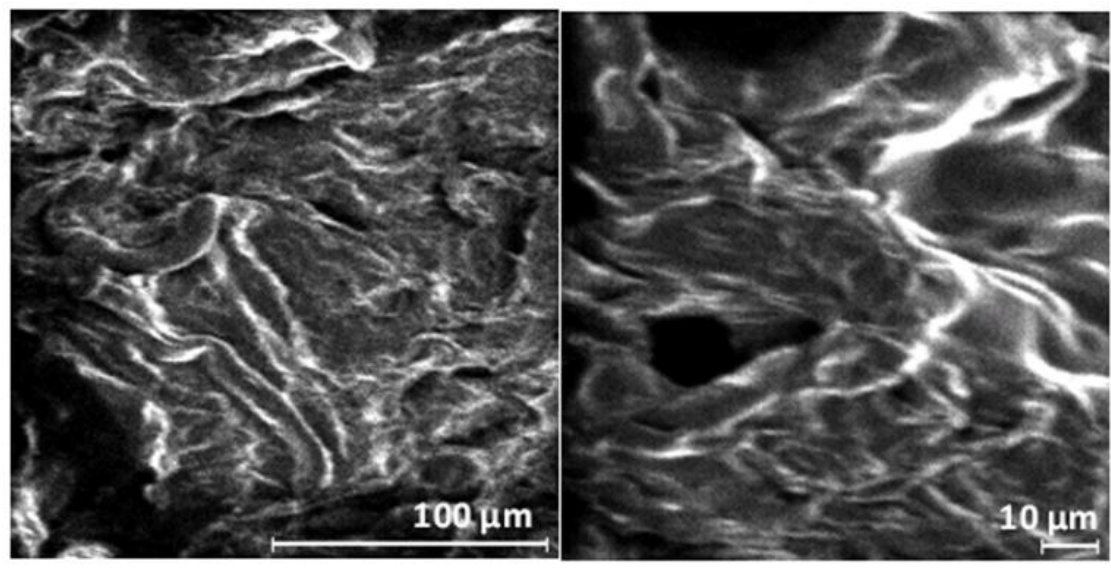

A intensidade de pico no fragmento de massa 99 para o filme de celulose foi claramente menor em comparação com filme de hexanoato sem celulose. As intensidades de pico normalizadas foram calculadas (Tabela 14). 
Tabela 14 - Comparação da intensidade de contagem de massa do fragmento 99 representação o grupo lateral hexanoato no espectro positivo de ToF-SIMS. As intensidades foram normalizadas pelo número total de contagem.

\begin{tabular}{cc}
\hline Amostra & Intensidade normalizada em $\mathbf{~} / \mathbf{z} 99$ \\
\hline Cel & 0,4 \\
Hexl,8 & 3,9 \\
Hexl,8/20Cel & 3,1 \\
\hline
\end{tabular}

Ademais, observa-se que houve um decréscimo na intensidade de pico no fragmento

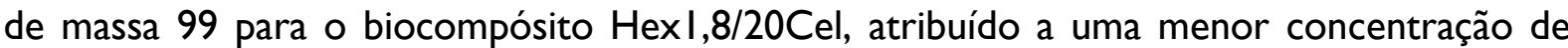
hexanoato de celulose ao longo do filme, em comparação ao filme referência do éster.

\section{3 Ângulo de contato}

A Figura 66 apresenta as curvas das medidas de ângulo de contato para o filme de celulose, filmes de ésteres e de respectivos biocompósitos preparados a partir da mistura dos ésteres de celulose e celulose. A seguinte discussão irá também focar nos valores de histerese do ângulo de contato (chamado doravante, apenas de histerese), propriedade que representa a diferença entre os valores máximos e mínimos do ângulo de contato. Essa técnica tem sido frequentemente utilizada para caracterizar propriedades de superfície, tais como caráter hidrofilico, rugosidade e heterogeneidade (GRUNDKE et al., 1996; GOMES et al., 2007). 
Figura 66 - Ângulo de contato em função do tempo: (a) filme de celulose e filmes de ésteres de celulose (GS I,8); (b) filmes de butanoatos de celulose com diferentes GS $(0,7-I, 8)$ e (c) filme de celulose e filmes de ésteres de celulose com GS I,8 e seus respectivos biocompósitos ( $20 \%$ de celulose).
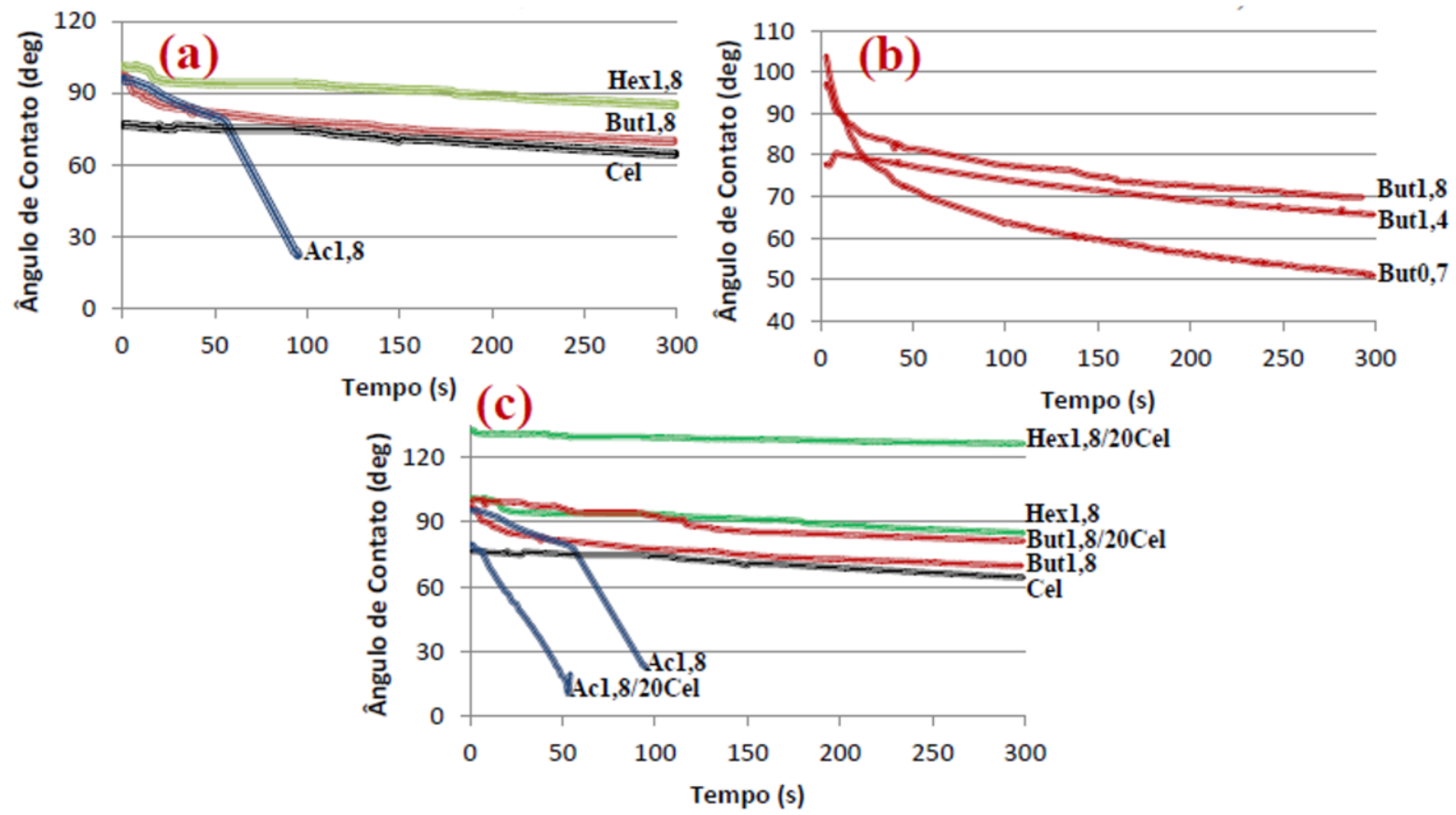

A partir das curvas de ângulo de contato em função do tempo (Figura 66), obteve-se os valores de ângulo de avanço (máximo) e ângulo de recuo (mínimo), assim como os valores de histerese (diferença entre os ângulos mencionados). Os valores supracitados estão sumariados na Tabela I5. 
Tabela 15 - Ângulos de avanço e de recuo para o filme de celulose, filmes de ésteres de celulose e biocompósitos a partir de ésteres de celulose e celulose.

\begin{tabular}{c|c|c|c|}
\hline Filme/Biocompósito & \multicolumn{3}{|c|}{ Ângulo ( $\left.{ }^{\circ}\right)$} \\
\hline \multirow{2}{*}{ Cel } & Avanço & Recuo & Histerese \\
\hline Acl,8 & 76,5 & $62, I$ & 14,4 \\
\hline Acl, $8 / 20$ Cel & 95,6 & 22,3 & 73,4 \\
\cline { 2 - 4 } But0,7 & 79,8 & 19,5 & 60,2 \\
ButI,4 & 103,8 & 50,9 & 52,8 \\
ButI,8 & 77,8 & 65,6 & 12,2 \\
\cline { 2 - 4 } ButI,8/20Cel & 97,1 & 69,8 & 27,3 \\
\cline { 2 - 4 } HexI,8 & 99,9 & 80,0 & 20,0 \\
\cline { 2 - 4 } HexI,8/20Cel & 101,4 & 83,6 & 17,8 \\
\cline { 2 - 4 } & 132,4 & 125,7 & 6,7 \\
\hline
\end{tabular}

Podem ser observados valores superiores de ângulos de avanço para os filmes de

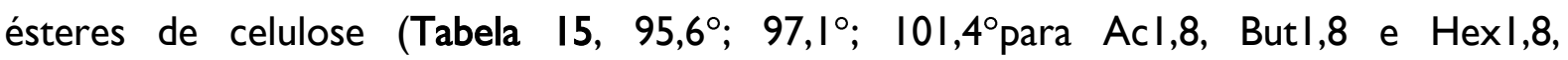
respectivamente) em comparação ao filme de celulose (Cel, $76,5^{\circ}$ ), indicando um maior (e crescente) caráter hidrofóbico para os primeiros. Esse resultado pode ser atribuído à presença dos grupos ésteres nas superfícies dos filmes, o que concede um maior caráter hidrofóbico, acompanhando o aumento da cadeia do éster, quanto comparado aos grupos hidroxilas altamente polares presentes na estrutura da celulose. CRÉPY et al. (2009) reportou valores de ângulo de contato passando por um máximo entre 100 e $109^{\circ}$ para ésteres de ácidos graxos (12-18 carbonos).

Em relação ao filme Acl,8, observa-se que o ângulo de avanço $\left(95,6^{\circ}\right.$, Tabela 15) foi maior que aquele obtido para o filme de celulose $\left(76,5^{\circ} \mathrm{C}\right.$, Tabela 15), como uma consequência da interação da gota de água e os domínios hidrofóbicos presentes na superfície de $A c l, 8$. Entretanto, o contato entre a superfície do filme $A c l, 8$ e a gota de água levou a uma projeção da superfície em direção à gota, gerando uma protuberância na superfície. Esse fenômeno progrediu rapidamente até total absorção da gota de água em direção à protuberância gerada. Assim, como consequência da absorção da gota de água, o ângulo de contato decresceu rapidamente, levando a um alto valor de histerese $\left(79,4^{\circ}\right)$ para $\mathrm{Acl}$,8, em um curto intervalo de tempo (Tabela 15). 
Os resultados mencionados no parágrafo anterior podem indicar que, inicialmente, a gota de água interagiu com os domínios hidrofóbicos presentes na superfície de Acl,8 e, logo após esse primeiro contato, seguiu interagindo com os domínios hidrofílicos, o que levou ao maior valor de histerese quando comparado ao filme de celulose (14,4 $4^{\circ}$, Tabela I5). Em relação ao filme de celulose (Cel), os grupos hidroxilas estariam participando preferencialmente de ligações hidrogênio intra e intermoleculares, justificando a menor dependência temporal do ângulo de contato da gota com a superfície do filme. A interação da água com os domínios hidrofílicos do acetato $(A c I, 8)$ envolve tanto grupos hidroxilas livres como carbonilas, aumentando a afinidade com a água, a qual por sua vez pode ser favorecida pelo menor tamanho da cadeia éster, quando comparado aos outros ésteres de maior cadeia.

Pode-se observar que a histerese para But I,8 e Hex I,8 (Tabela 15, 27,3 ${ }^{\circ}$ e 17,8 respectivamente) decresceu em relação a $\mathrm{Acl}, 8\left(79,4^{\circ}\right)$. Esse fato pode ser atribuído ao aumento do caráter hidrofóbico conforme se aumenta o tamanho da cadeia do éster, assim como a um maior efeito de impedimento estérico que essas cadeias ésteres conferem às hidroxilas e grupos carbonilas, entravando as interações com a água.

O filme de butanoato de celulose de menor GS, But0,7, apresentou o maior ângulo de avanço (52,8 $8^{\circ}$ Tabela 15) em comparação aos butanoatos de maiores GS (But l,4 e But I,8, Tabela 15), o que indicaria um menor caráter hidrofílico, contrariamente ao que seria esperado. Entretanto, But0,7 apresentou a maior histerese (53, Tabela 2), em comparação a Butl,4 e Butl,8, indicando sua alta afinidade com água.

É de conhecimento geral que o primeiro contato da gota de água com a superfície (Rodrigues et al., 20l4), o qual denota o ângulo de avanço, é altamente influenciado pela morfologia da superfície. Como pode ser observado nas figuras de MEV (Figura 43), But0,7 apresentou uma superfície mais compacta e lisa quando comparada às superfícies dos filmes de GS superiores (Butl,4 e Butl,8), os quais apresentaram estruturas fibrosas e microesferas em suas superfícies. A presença destes elementos nas superfícies de Butl,4 e Butl,8 podem ter influenciado a interação com a água, isto é, os ângulos de avanço observados podem não refletir exatamente a afinidade dessas superfícies com a água. 
Em relação aos filmes de butanoatos, conforme se aumentou o GS (0,7 para I,4 e I,8), menores valores de histerese foram observados (Tabela $15,52,8^{\circ}$ para $12,2^{\circ}$ e $27,3^{\circ} \mathrm{m}$ respectivamente), devido ao aumento do caráter hidrofóbico nas superfícies dos filmes.

As curvas presentes na Figura 66 mostram diferentes comportamentos em relação à presença da celulose nos biocompósitos, com uma forte dependência com o tamanho da cadeia éster. A presença de celulose no filme de acetato de celulose de GS I,8, Acl,8/20Cel, levou a um biocompósito com maior caráter hidrofílico, resultando em um menor ângulo de

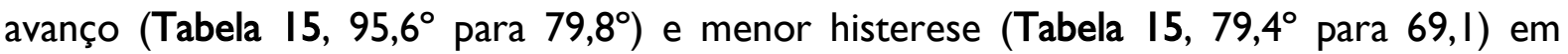
relação ao filme puro $(A c l, 8)$. Ressalta-se que $A c l, 8 / 20 C$ el exibiu o mesmo comportamento previamente descrito para o filme puro $(\mathrm{Acl}, 8)$, observando-se também o surgimento de uma protuberância após o primeiro contato da superfície com uma gota de água, seguido de completa absorção após um curto período. Consequentemente, esse biocompósito apresentou o maior valor de histerese entre todos os outros, corroborando com o que foi observado para o conjunto de filmes puros (sem celulose). Destaca-se, ainda, que os resultados XPS indicaram maior presença de celulose na superfície de Acl,8 (comparativamente aos outros ésteres), o que pode também ter contribuído para com o comportamento observado.

Para os filmes de butanoato de celulose e hexanoato de celulose, a adição de celulose levou a biocompósitos com maiores ângulos de avanço (Tabela 15, 97, $1^{\circ}$ para 99,9 e $101,4^{\circ}$ para $132^{\circ}$, respectivamente), com significativo decréscimo na histerese (Tabela 15 , 27,3 para $19,9^{\circ}$ e $17,8^{\circ}$ para $6,7^{\circ}$, respectivamente), indicando um menor caráter hidrofílico das superfícies dos biocompósitos. Essa tendência observada está de acordo com os resultados obtidos via análise XPS (seção 4.I.2), nos quais a cobertura da superfície dos filmes pelas cadeias de ésteres de celulose foi analisada em termos de $\mathrm{Cl}$.

Nas análises via XPS, um decréscimo na cobertura da superfície por cadeias de acetato foi observado para $\mathrm{Acl}, 8 / 20 \mathrm{Cel}$ (Figura 6I) quando comparado ao filme puro (Acl,8, Figura 6I), enquanto que para o biocompósito a partir de butanoato de celulose (Butl,8/20Cel, Figura 6I), houve um aumento nessa propriedade em relação ao filme puro (Butl,8, Figura 6I). A presença de celulose levou a um aumento ainda maior na cobertura da superfície por cadeias ésteres em Hexl,8/20Cel (Figura 6I), quando comparado ao filme puro (Hexl,8, Figura 6I). Esses resultados indicariam uma maior presença de celulose na superfície do biocompósito preparado a partir de acetato de celulose, levando a uma 
superfície mais hidrofílica, assim como constado via análises XPS. Em contrapartida, o aumento da cobertura superficial por cadeias ésteres nos filmes preparados a partir de cadeias maiores (butanoatos e hexanoatos) indicaria um aumento no caráter hidrofóbico de suas superfícies, assim como verificado nos resultados de ângulo de contato. 


\section{Breve Sumário e Conclusões Parciais}

Em linhas gerais, o uso de técnicas avançadas de caracterização de superfícies permitiu estabelecer importantes correlações entre as diferentes matrizes dos filmes/biocompósitos, preparadas a partir de ésteres de celulose de sisal com diferentes tamanhos de cadeia, GS, assim como investigação sobre a influência da presença da celulose.

Os resultados de XPS revelaram um aumento na contribuição do carbono alifático com o aumento do GS, quando a cadeia lateral manteve-se constante (butanoatos), assim como um decréscimo na razão $\mathrm{O} / \mathrm{C}$, confirmando as modificações esperadas nas fibras celulósicas. Ademais, os resultados de XPS mostraram que as razões O/C para os biocompósitos (GS 1,8, 20\% celulose) foram superiores em comparações aos filmes de ésteres puros, sem a presença de celulose. Concomitantemente, a razão $\mathrm{O} / \mathrm{C}$ diminuiu com o aumento da cadeia lateral (Acetatos $>$ Butanoatos $>$ Hexanoatos). De acordo com os dados de ToF-SIMS, os grupos ésteres estavam uniformemente distribuídos ao longo das superfícies dos filmes e biocompósitos.

A adição de celulose à matriz de acetato de celulose gerou um biocompósito mais hidrofílico, resultando em um menor ângulo de contato de avanço. Em contrapartida, a adição de celulose às matrizes de butanoato e hexanoato de celulose aumentou o ângulo de contato de avanço e diminuiu a histerese, indicando a diminuição de hidrofilicidade nas superfícies dos biocompósitos; a diminuição do caráter hidrofílico foi devido à maior cobertura das superfícies destes biocompósitos por cadeias ésteres alifáticas (verificado por XPS). Os resultados apresentados neste trabalho aumentaram a compreensão das interações entre a celulose e as cadeias de ésteres de celulose em filmes preparados a partir dessas macromoléculas. Além disso, estes resultados forneceram importantes informações a respeito da distribuição destas cadeias ao longo da superfície dos filmes e biocompósitos.

Os capítulos seguintes irão tratar da utilização da celulose de sisal, ou mesmo a fibra lignocelulósica de sisal, na preparação de diferentes materiais. O Capítulo 4 descreve um estudo que visou estabelecer condições ótimas na obtenção de microesferas (beads) de celulose de sisal. O Capítulo 5 corresponde a um estudo da eletrofiação de soluções preparadas a partir da fibra lignocelulósica de sisal, ou da celulose extraída a partir dela, 
visando à obtenção de membranas (mats) constituídas por fibras na escala submicrométrica e nanométricas. 


\section{CAP 4. MICROESFERAS DE CELULOSE DE SISAL}

Como mencionado anteriormente, este o próximo capítulos são centrados na valorização da celulose de sisal, ou da fibra lignocelulósica de sisal, como matérias primas para a preparação de diferentes materiais: microesferas (beads) e membranas (mats) constituídas por fibras na escala sub e nanométricas. Este capítulo reporta um estudo que visou à busca de condições de pré-tratamento da polpa celulósica de sisal que propiciasse a sua adequada dissolução em sistema aquoso constituído por $\mathrm{NaOH} /$ réia. Assim, após a dissolução, pôde-se estudar a obtenção de microesferas de celulose de sisal via coagulação em meio ácido.

\section{Introdução}

\section{I.I Microesferas de celulose}

As microesferas de celulose (denominadas beads, em inglês) (Figura 67) são partículas esféricas porosas que apresentam uma vasta gama de aplicação em variados campos. Microesferas de celulose têm sido descritas em patentes desde 195I(O'NEILL JR.; REICHARDT, 195I), com os primeiros produtos comerciais surgindo a partir da década de 1970 (PEŠKA et al., 1976). O princípio geral envolvido na preparação destas microesferas, usualmente, concerne à dissolução de um derivado de celulose (como ésteres e éteres de celulose), seguido da regeneração da celulose em um banho de coagulação, no qual a composição química é própria para se realizar a “des-derivatização”, ou seja, hidrólise, desacetilação, dentre outras reações (BAI; LI, 2006). 
Figura 67 - Microesfera de celulose (DU et al., 2010).

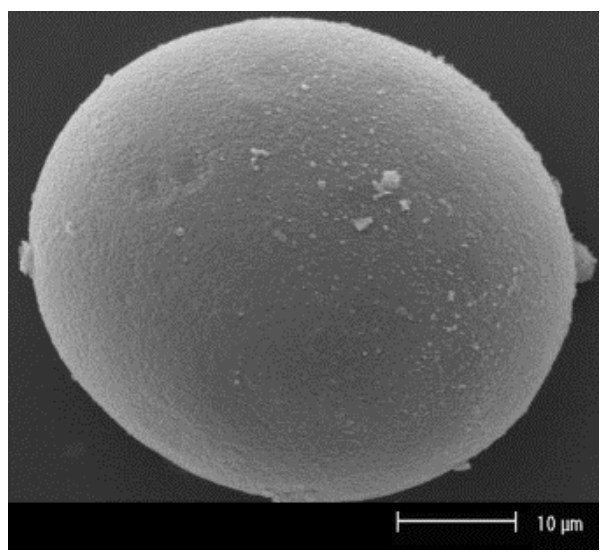

As microesferas de celulose podem ser preparadas a partir de soluções, seja pelo uso de instrumentos clássicos, como os atomizadores (ROSENBERG et al., 2007), ou mesmo em escala de laboratório, com uma seringa (TRYGG et al., 20I2; TRYGG et al., 20I4) ou pela pressão em uma solução através de um material perfurado (LINKO et al., 1977). Para se melhorar algumas propriedades específicas de absorção, a celulose pode ser co-dissolvida com outros tipos de polissacarídeos, como quitina (ZHOU; ZHANG; GUO, 2005) ou quitosana (DUAN et al., 20I2; VIJAYALAKSHMI; GOMATHI; SUDHA, 20I4). A mistura de celulose com ésteres de celulose em solventes comuns tem se mostrado como uma estratégia muito influente na razão de aspecto das microesferas formadas (DE OLIVEIRA; GLASSER, 1996).

As microesferas com alta porosidade e alta estabilidade a altas pressões são de especial interesse na área cromatográfica, com aplicações direcionadas a técnicas de separação. Na literatura são encontrados estudos onde microesferas de celulose e de celulose quimicamente modificada são usadas em diversas aplicações cromatográficas, como por exemplo, em Cromatografia de Exclusão por Tamanho (ZHANG, Q. L. et al., 20I4). Outras aplicações para as microesferas de celulose e seus derivados são encontradas no uso destas no suporte de síntese de fases sólidas (YAN et al., 2013), processos de trocas de íons (HIROTA et al., 2009), remoção de íons pesados (ZHOU et al., 2004; GONTE; BALASUBRAMANIAN; MUMBREKAR, 20I3) e imobilização de enzimas (CHEN; TSAO, 1977; WU et al., 20I4).

Nas duas últimas décadas, grandes avanços na de área de liberação controlada tem sido alcançada e numerosas abordagens têm sido investigadas e detalhadas a respeito do comportamento na liberação de fármacos específicos. As microesferas de celulose e seus 
derivados têm encontrado um significante espaço nesta área (GERICKE; TRYGG; FARDIM, 20I3; YILDIR et al., 20I3; TRYGG et al., 20I4). BAJEROVA et al. (20II) demonstraram a possibilidade da obtenção de microesferas de oxicelulose contendo diclofenaco de potássio com um alto desempenho de aprisionamento e encapsulamento do fármaco. Drogas baseadas no acoplamento de benzocaína e prazosin por ligações covalentes e iônicas a microesferas de celulose modificada, com posterior confecção de comprimidos, também são relatadas (VOLKERT et al., 2009). Mais recentemente, YILDIR et al. (20I3) reportaram um estudo usando diferentes métodos de preparação de microesferas porosas de celulose para posterior uso como carreadores de fármacos, como teofilina, 5'-fosfato de riboflavina e cloridrato de lidocaína monoidratada

No presente trabalho, celulose de sisal e celulose microcristalina foram usadas como matéria-prima na preparação de microesferas, por meio da extrusão de soluções preparadas a partir destes polímeros em solução coagulante, e posterior caracterização de suas propriedades, visando gerar informações úteis frente a possibilidade de aplicação destes materiais nos mais diversos campos.

\section{I.2 Sistema de solvente aquoso $\mathrm{NaOH} /$ Uréia}

Nos últimos anos, tem crescido o número de investigações envolvendo a dissolução de celulose em soluções aquosas contendo $\mathrm{NaOH}$ e Uréia e potenciais aplicações. Iniciado no começo da década de 2000 (ZHOU; ZHANG, 2000; ZHANG; RUAN; ZHOU, 200I), o uso de soluções aquosas de $\mathrm{NaOH} /$ Uréia (ZHANG, D. et al., 20I2), $\mathrm{NaOH} / T$ iouréia (ALMEIDA et al., 20I0; MORGADO; FROLLINI; et al., 20II) e mesmo $\mathrm{NaOH} /$ Uréia/Tiouréia (Zuo, 20l3) tem despertado grande atenção e interesse, visto a necessidade atual de busca por solventes verdes ou ditos “environmental friendly”. Diversos estudos caminham em direção a procurar as composições ótimas para a mistura $\mathrm{NaOH} /$ Uréia e $\mathrm{NaOH} / T$ iouréia, sendo comumente citado o uso de $6 \% \mathrm{NaOH} / 4 \%$ Uéia, $7 \% \mathrm{NaOH} / 12 \%$ Uréia e $6 \% \mathrm{NaOH} / 5 \%$ Tiouréia (ZHOU; ZHANG, 2000; ZHANG; RUAN; GAO, 2002; ZHOU et al., 2002; ZHOU et al., 2005; TRYGG; FARDIM, 20I I; ZHANG, D. et al., 20।2). 
Diversos estudos têm sido publicados ao longo dos últimos 15 anos procurando entender os aspectos e mecanismos envolvidos na dissolução da celulose em sistemas álcalis com uréia, tiouréia e a mistura destes (ZHOU; ZHANG, 2000; ZHANG; RUAN; GAO, 2002; QI; CHANG; ZHANG, 2008; XIONG et al., 20I4). Estudos demonstram que sistemas aquosos baseados em álcalis $(\mathrm{LiOH}$ ou $\mathrm{NaOH})$ misturados com Uréia/Tiouréia são não derivatizantes para a dissolução e formação de soluções verdadeiras de celulose. Alguns mecanismos propostos se baseiam na formação de complexos de hidratos de $\mathrm{NaOH}-$ hidratos de uréia - água livre - celulose (Figura 68) . NaOH ou LiOH seria responsáveis pela destruição das ligações intra e intermoleculares entre as moléculas de celulose (Figura 3), facilitando a separação das cadeias de polímero. Hidrato de uréia agiria como doadorreceptor de ligações hidrogênio entre as moléculas do solvente, evitando a reassociação das moléculas de celulose, assim levando a dissolução molecular deste polímero (CAl et al., 2008).

Figura 68 - Representação esquemática da formação de complexos entre de hidratos de

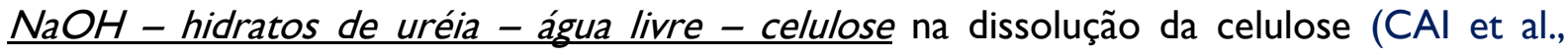
2008).

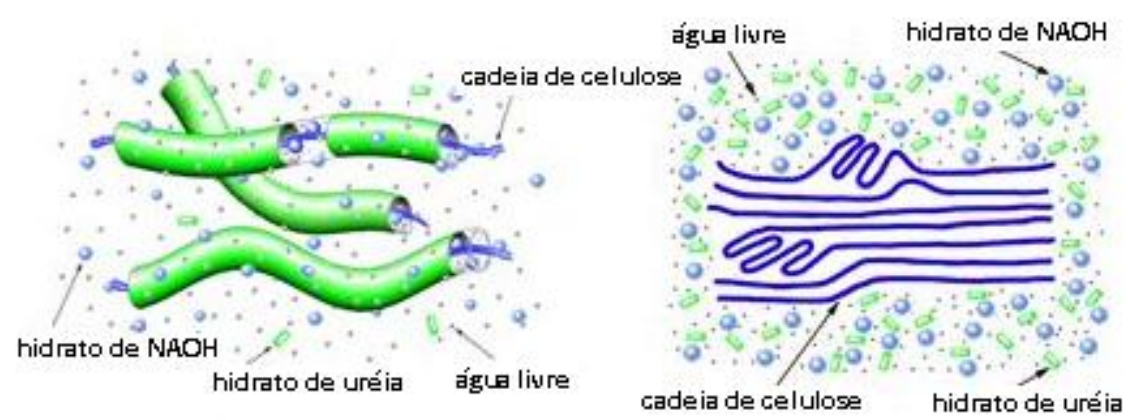

Estudos recentes têm sido reportados em que tentativas de melhor elucidar o papel da uréia na dissolução da celulose, em sistemas alcalinos aquosos, são descritas. ISOBE, NORIYUKI et al. (20I3), via monitoramento da dissolução da celulose neste sistema de solvente utilizando as técnicas de DSC e raios $X$, sugeriu não haver interação direta da uréia com a celulose durante o processo de dissolução. Entretanto, segundo ISOBE, NORIYUKI et al. (20I3) a uréia apresenta um importante papel na diminuição da cristalinidade da celulose e talvez ajude o hidrato álcali a penetrar nas regiões cristalinas da celulose por meio da estabilização das moléculas de celulose intumescidas, levando a um aumento da fração dissolvida da celulose. Segundo ISOBE, NORIYUKI et al. (20I3), esta estabilização seria devido a um acumulo local de uréia na região hidrofóbica da superfície da celulose, 
prevenindo que as cadeias celulósicas dissolvidas se associem via interações desta natureza. A hipótese de que a insolubilidade da celulose pode ser associada a características hidrofóbicas desta foi primeiramente reportada por LINDMAN; KARLSTRÖM; STIGSSON (2010), e ficou conhecida como "the Lindman hypothesis".

O papel da uréia na dissolução de celulose em soluções de $\mathrm{NaOH}$ /uréia foi também estudado via RMN, em um estudo recentemente publicado por XIONG et al. (20I4). Neste estudo, os resultados sugeriram que a uréia não apresenta interação direta com a celulose e $\mathrm{NaOH}$, assim como não há influência da uréia nas dinâmicas estruturais da água. Segundo XIONG et al. (20l4), durante a dissolução, os grupos hidroxílicos da celulose estariam interagindo preferencialmente, via ligações hidrogênio, com os íons $\mathrm{OH}^{-}(\mathrm{NaOH})$ e moléculas de água. A uréia seria responsável por aumentar a solubilidade e estabilidade da celulose em solução acumulando-se próxima às regiões hidrofóbicas via forças de van der Waals, assim prevenindo que as moléculas de celulose se reagregassem. Assim, o papel da uréia estaria muito mais na direção de estabilizar a solução do que de romper ligações hidrogênio e dissolver a celulose. Este resultado estaria em consonância com o anteriormente proposto por LINDMAN; KARLSTRÖM; STIGSSON (2010) e ISOBE, NORIYUKI et al. (20I3). Assim, no processo de dissolução, $\mathrm{OH}^{-}$seria responsável por romper as ligações hidrogênio, $\mathrm{Na}^{+}$estabilizaria os grupos hidroxilas (hidrofílicos) e uréia estabilizaria a parte hidrofóbica da celulose.

ZHOU et al. (2005) investigaram a dissolução de O-(2-hidróxietil) celulose (HEC) em soluções aquosas de $6 \% \mathrm{NaOH} / 4 \%$ Uréia, examinando as características desse sistema de solvente em particular, assim como a esterificação da celulose em meio homogêneo. Mudanças estruturais e ativação da celulose por soluções alcalinas com uréia foram também estudadas por KUNZE; FINK (2005). Vários trabalhos na literatura sugerem que há um limite máximo no GP da celulose para dissolução (em diferentes composições do sistema de solvente), sendo que celuloses com GP superiores a certos valores não poderiam ser dissolvidas em determinadas soluções (ZHOU; ZHANG, 2000; ZHOU et al., 2002; ZHOU et al., 2005).

No presente trabalho, utilizou-se o sistema de solvente aquoso baseado em $7 \% \mathrm{NaOH} / 12 \%$ Uréia, o qual tem demonstrado comprovada eficiência para a dissolução de celulose ao longo da última década (ZHANG; RUAN; ZHOU, 200I; ZHOU et al., 2005; TRYGG et al., 20I2). 


\section{I.3 Pré-tratamento na biomassa celulósica}

Como já discutido anteriormente, sistemas aquosos baseados em $\mathrm{NaOH}$, com ou sem aditivos (e.g., uréia e tiouréia), tem recebido grande atenção como meios aquosos baratos e ecologicamente viáveis. Entretanto, tem sido demonstrado que assim como no sistema de solvente DMAc/LiCl (RAMOS, L. et al., 20II), as moléculas de celulose não estão completamente dissolvidas em sistemas aquosos baseados em $\mathrm{NaOH}$, levando à formação e coexistência de agregados (ROY; BUDTOVA; NAVARD, 2003). Ademais, a dependência da solubilidade da celulose com ○ GP também tem sido estudado nestes sistemas, com resultados apontando que apenas celuloses de baixo GP podem ser dissolvidas (QI; CHANG; ZHANG, 2008; TRYGG; FARDIM, 20II). Estes fatos demonstram que para muitos sistemas de solventes, como DMAc/LiCl e aqueles baseados em $\mathrm{NaOH}_{(\mathrm{aq.})}$, há a necessidade de pré-tratamentos na massa celulósica, visando à redução do tamanho da cadeia polimérica, assim como também a cristalinidade em alguns casos.

Ressalta-se que a redução do GP é, em muitas vezes, condicionada à necessidade de se obter soluções com concentrações superiores ao limite geralmente alcançado na dissolução da celulose em questão. Um bom exemplo é a preparação de microesferas de celulose, como acontece no presente capítulo, via coagulação de soluções de celulose em meio ácido: soluções com concentrações muito baixas podem se mostrar não adequadas para coagulação. Por outro lado, a redução do GP para conseguir o aumento da concentração na dissolução tem que ser estudada com cuidado, pois um GP muito baixo pode levar à formação de microesferas com baixas propriedades mecânicas, de modo que a coagulação por si só pode ser inviabilizada.

O próximo tópico abordará alguns aspectos importantes a cerca de um tipo de prétratamento (ácido) em massa celulósica, o qual foi utilizado neste trabalho visando garantir a dissolução da celulose de sisal no sistema de solvente aquoso baseado em $\mathrm{NaOH} /$ Uréia. 


\section{Tratamento Ácido}

A hidrólise ácida tem sido constantemente aplicada como um tipo de pré-tratamento para gerar cadeias celulósicas menores e mais acessíveis para agentes químicos. Tradicionalmente, a hidrólise é usada a altas temperaturas e baixas concentrações de ácido, ou vice-versa (ADEL et al., 2010). Entretanto, além da grande demanda de energia necessária para esse processo, há o problema relacionado à degradação de açúcares gerados durante a hidrólise e consequentemente a formação de subprodutos indesejáveis, como ○ furfural, ácido fórmico e ácido acético (LIU et al., 1999).

Tratamentos ácidos em massa celulósica são em sua maioria conduzidos em meios aquosos. Investigações têm mostrado que a hidrólise ácida conduzida em álcool aumenta a degradação da celulose (LIN; CHANG; HSU, 2009) em relação àquela conduzida em meio aquoso, o que pode ser provavelmente explicado ao maior coeficiente de atividade dos íons hidrogênio no primeiro (HARNED; FLEYSHER, 1925). A influência na hidrólise da celulose realizada em água ou etanol foi investigada por LIN; CHANG; HSU (2009), o qual demonstrou que a taxa de degradação da celulose tem uma forte dependência com o meio, favorecendo o uso do etanol. TRYGG; FARDIM (20II) investigaram o uso de solução de etanol-HCl, em diferentes temperaturas, no tratamento da massa celulósica. Neste estudo, TRYGG; FARDIM (20II) avaliaram, via microscopia e métodos reológicos, o efeito de diferentes condições de pré-tratamento na solubilidade da celulose em $\mathrm{NaOH}_{(\text {aq.) }} /$ Uréia.

No presente trabalho, celulose de sisal (nativa e mercerizada) foi submetida a diferentes condições de pré-tratamento em meio etanol-ácido, visando gerar celulose em condição ótima para posterior dissolução no sistema aquoso $7 \% \mathrm{NaOH} / 2 \%$ Uréia. Entendese condição ótima aquela em que a dissolução levasse a uma solução homogênea e transparente, passível de posterior coagulação para formação de microesferas de celulose (concentração e viscosidade adequadas). 


\section{Experimental}

\section{I Materiais}

Celulose de sisal (GP: 743, Índice de cristalinidade (Ic): 72\%, Capítulo I, seções 3.I.2 e 3.I.3), celulose de sisal mercerizada (GP: 680, Ic: 63\%, ver Capítulo I, seções 3.1 .2 e 3.I.3) e celulose microcristalina Avicel PH-IOI (GP: 126, Ic: 8I\%, caracterizada segundo os procedimentos descritos anteriormente, Capítulo I, seções 2.2.4 e 2.2.5) foram utilizadas no presente estudo. A celulose microcristalina foi adquirida pela empresa FMC, Inc. (São Paulo, Brasil).

Etanol comercial (92,5\%) e ácido clorídrico (37\%) (Merck KGaA) foram utilizados no tratamento da celulose de sisal e celulose de sisal mercerizada.

Para a dissolução da celulose no sistema aquoso $\mathrm{NaOH} /$ Uréia e posterior coagulação para geração de microesferas, utilizou-se Uréia (99,5\%) e ácido nítrico (65\%), ambos da Merck KGaA e $\mathrm{NaOH}(97 \%)$ da Fluka Analytical.

\subsection{Pré-tratamento da celulose de sisal}

Celulose de sisal (Sc) e celulose de sisal mercerizada (ScM) foram tratadas em um sistema composto por etanol 92,5\% / ácido clorídrico 37\% (4\%) a $75{ }^{\circ} \mathrm{C}$, em diferentes intervalos de tempo (2-5h) (TRYGG; FARDIM, 20II). O material foi seco em estufa de circulação a $60{ }^{\circ} \mathrm{C}$ por $24 \mathrm{~h}$ e posteriormente armazenado em temperatura ambiente. Diferentes condições de pré-tratamento foram estudadas, procurando uma condição ótima para a posterior dissolução da celulose no solvente aquoso baseado em $\mathrm{NaOH} / \mathrm{U}$ réia. 


\subsection{Pré-Estudo da dissolução da celulose de sisal no sistema aquoso baseado em $\mathrm{NaOH} /$ Uréia}

Visando-se obter a melhor condição para dissolução e posterior coagulação das microesferas, soluções aquosas de SC e ScM (tratadas e não-tratadas em etanol/ácido clorídrico) em $7 \% \mathrm{NaOH} / 12 \%$ Uréia foram preparadas, com a massa de celulose seca variando em um intervalo de $2 \%-6 \%$ da massa total da solução final. O conteúdo de umidade da celulose foi incluído na quantidade final de água da solução. Após 20 min de vigorosa agitação, a suspensão foi resfriada a $-12^{\circ} \mathrm{C}$ seguindo com agitação por mais $30 \mathrm{~min}$. Após esse período, verificou-se visualmente a solubilidade da celulose no sistema de solvente.

\subsection{Preparação das microesferas de celulose a partir da dissolução em $\mathrm{NaOH} /$ Uréia}

Microesferas de celulose de sisal e celulose microcristalina foram preparados por meio da extrusão a frio $\left(-12^{\circ} \mathrm{C}\right)$ das soluções aquosas dos polímeros em $\mathrm{NaOH} /$ Uréia diretamente na solução ácida coagulante $\left(\mathrm{HNO}_{3}\right)$. O esquema geral de dissolução e coagulação é representado na Figura 69.

Figura 69 - Esquema geral da dissolução da celulose e posterior regeneração na forma de microesferas via extrusão da solução, a partir de seringa, em banho coagulante ácido.

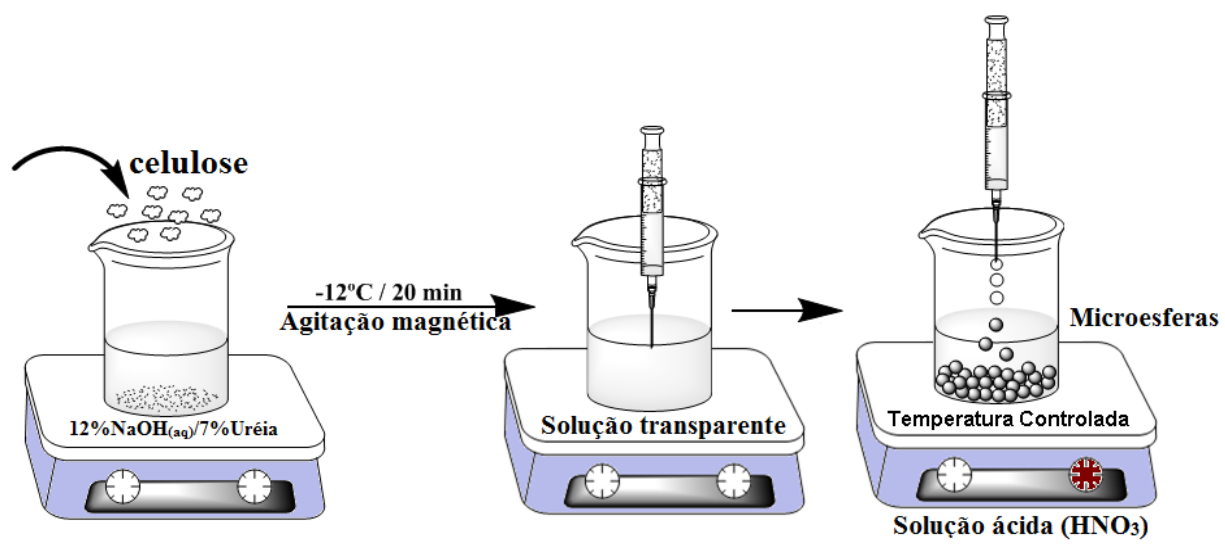


O processo de extrusão foi realizada utilizando seringas $(5 \mathrm{~mL})$ Eppendorf, localizadas a $\mathrm{I} \mathrm{cm}$ acima da superfície das soluções. A temperatura e concentração ácida do meio coagulante foram variadas separadamente, mantendo-se sempre uma variável constante. Em cada experimento, grandes volumes do meio ácido coagulante foram usados, visando minimizar a neutralização, visto que a solução extrudada apresentava forte caráter alcalino. O efeito da concentração ácida do meio coagulante na coagulação das microesferas de celulose (sisal e microcristalina) foi estudado em diferentes concentrações de ácido nítrico $(2,4$ e $6 \mathrm{M})$ a $25^{\circ} \mathrm{C}$. O efeito da temperatura na coagulação foi estudado em meio coagulante $4 \mathrm{M}$ a 25,50 e $70{ }^{\circ} \mathrm{C}$, para ambos os tipos de celulose.. As microesferas coaguladas a 50 e $70{ }^{\circ} \mathrm{C}$ foram mantidos nesta temperatura por $2 \mathrm{~h}$, com posterior resfriamento até atingir temperatura ambiente. As microesferas foram mantidas na solução ácida por $24 \mathrm{~h}$. Após esse período, as mesmas foram exaustivamente lavadas com água corrente e posteriormente água destilada (onde ficaram armazenados até posterior caracterização), até que o pH da água de lavagem fosse atingido.

\subsection{Caracterização das microesferas}

\subsection{FE-SEM}

As morfologias das superfícies das microesferas de celulose de sisal e microcristalina foram analisadas por FE-SEM em um equipamento LEO Gemini I530. As amostras foram recobertas com carbono e magnificacões da ordem de 500-10000x foram consideradas. 


\subsubsection{Determinação da área, volume, índice de circularidade e porosidade total das microesferas de celulose}

A área, volume e índice de circularidade das microesferas de celulose foram avaliados seguindo o método reportando por (TRYGG et al., 20I2). Baseado neste método, para cada amostra foram obtidas imagens para uma população média de 100-150 microesferas secas apenas em papel e posteriormente secas em estufa de circulação a $105^{\circ} \mathrm{C}$ por $4 \mathrm{~h}$. A massa média das microesferas secas em papel, assim como também para aquelas secas em estufa, foi determina a partir de uma população mínima de trinta microesferas. As imagens, obtidas com auxílio de um escâner, foram processadas pelo Software Fiji Image Processing. As imagens óticas foram convertidas para imagens binárias e a forma ajustada para elipses. Assim, puderam-se calcular os valores de áreas e índices de circularidade e, assumindo completa esfericidade das microesferas, calcularam-se os volumes a partir do comprimento do menor eixo da elipse. A porosidade total foi calculada a partir da massa das microesferas ainda intumescidas (secos em papel) e após secagem em estufa, considerando-se a densidade de $\mathrm{I}, 5 \mathrm{~g} \mathrm{~cm}^{-3}$ para a celulose (ETTENAUER et al., 20I I).

\subsubsection{Avaliação da resistência das microesferas de celulose após aplicação de força centrífuga em diferentes condições}

As microesferas (secas em papel) preparados a partir de celulose de sisal e celulose microcristalina foram submetidas a testes de resistência, os quais consistiram da centrifugação destas a partir do uso de diferentes velocidades rotacionais (1000-4000 rpm). O tamanho e forma foram determinados, assim como descrito na seção anterior, antes e após cada experimento de centrifugação. A comparação dos resultados obtidos foi realizada em direção de se avaliar como as propriedades consideradas são afetadas nas diferentes condições. 


\section{Resultados e discussão}

\section{I Estudo da dissolução da celulose de sisal no sistema aquoso $\mathrm{NaOH} /$ Uréia}

Em busca de uma condição ótima para dissolução (dissolução completa da celulose; \% de celulose adequada para a posterior coagulação das microesferas), diversas condições de pré-tratamento da celulose de sisal nativa $(\mathrm{Sc})$ e mercerizada $(\mathrm{ScM})$ foram testadas. O prétratamento ácido foi realizado em etanol $92,5 \% / \mathrm{HCl} 37,5 \%(4 \%)$, a $75^{\circ} \mathrm{C}$, em diferentes tempos (2, 3 e $5 \mathrm{~h})$ e dissoluções em diferentes \% de celulose foram testadas no sistema aquoso $7 \% \mathrm{NaOH} / 12 \%$ Uréia. Algumas dessas condições estão sumarizadas na Tabela 16. Nos casos em que a completa dissolução foi atingida, testou-se a formação de por meio da extrusão das soluções em ácido nítrico $2 \mathrm{M}$.

Tabela 16 - Diferentes condições de pré-tratamento (etanol-ácido, $75^{\circ} \mathrm{C}$ ) e dissolução em $\mathrm{NaOH}_{(\mathrm{aq} .)} /$ Uréia e avaliação de formação de microesferas em $\mathrm{HNO}_{3} 2 \mathrm{M}$.

\begin{tabular}{|c|c|c|c|c|}
\hline & Amostra & $\%$ Cel. & Dissolução em $\mathrm{NaOH}_{(\mathrm{aq} .)} /$ Uréia & Microesferas $\left(\mathrm{HNO}_{3}, 2 \mathrm{M}\right)$ \\
\hline $1^{\circ}$ & Sc & 2 & -- & -- \\
\hline $2^{\circ}$ & ScM & 2 & -- & -- \\
\hline $3^{\circ}$ & $\mathrm{P} 2 \mathrm{~h}-\mathrm{Sc}$ & 5 & -- & -- \\
\hline $4^{\circ}$ & $\mathrm{P} 2 \mathrm{~h}-\mathrm{ScM}$ & 5 & -- & -- \\
\hline $5^{\circ}$ & $\mathrm{P} 2 \mathrm{~h}-\mathrm{Sc}$ & 2 & Parcial & -- \\
\hline $6^{\circ}$ & $\mathrm{P} 2 \mathrm{~h}-\mathrm{ScM}$ & 2 & Sim & Não \\
\hline $7^{\circ}$ & $\mathrm{P} 2 \mathrm{~h}-\mathrm{ScM}$ & 3,5 & Sim & Não \\
\hline $8^{\circ}$ & $\mathrm{P} 2 \mathrm{~h}-\mathrm{ScM}$ & 4,0 & Sim & Beads irregulares e fracos* \\
\hline $9^{\circ}$ & $\mathrm{P} 2 \mathrm{~h}-\mathrm{ScM}$ & 4,5 & Parcial & -- \\
\hline $10^{\circ}$ & P3h-ScM & 4,5 & Parcial & -- \\
\hline $11^{\circ}$ & P3h-ScM & 5,0 & Parcial & -- \\
\hline $12^{\circ}$ & P5h-ScM & 4,5 & Sim & Não \\
\hline $13^{\circ}$ & P5h-ScM & 5,0 & Sim & Não \\
\hline $14^{\circ}$ & P3h-Sc* & 5,5 & Sim & Sim \\
\hline $15^{\circ}$ & P3h-ScM* & 5,5 & Sim & Sim \\
\hline
\end{tabular}

$P 2 h \rightarrow 2 h$ de tratamento; $P 3 h \rightarrow 3 h$ de tratamento; $P 5 h \rightarrow 5 h$ de tratamento.

* Apesar da formação de beads, a caracterização (antes e após secagem) mostrou-se não viável. 
$\mathrm{Na}$ Tabela 16, observa-se que as condições ótimas foram atingidas com prétratamento da massa celulósica por $3 \mathrm{~h}$ em etanol-ácido e dissolução em $7 \% \mathrm{NaOH}_{(\mathrm{aq})} / 12 \%$ Uréia em $5,5 \%\left(14^{\circ}\right.$ e $\left.15^{\circ}\right)$. Como explicado anteriormente, na seção experimental, todas as soluções foram centrifugadas após cada experimento de dissolução e novamente resfriadas por $10 \mathrm{~min}$. Todas as soluções, exceto as soluções $14^{\circ}$ e $15^{\circ}$ (transparentes), mostraram-se turvas previamente a centrifugação (presença de fibras celulósicas não dissolvidas). Entretanto, todas as soluções (incluindo $14^{\circ}$ e $15^{\circ}$ ) mostram-se, de certa forma, mais transparentes após centrifugação e resfriamento. Provavelmente, em relação às soluções $14^{\circ}$ e $15^{\circ}$, isto pode ser atribuído à remoção de contaminações insolúveis presentes na polpa celulósica ou mesmo a remoção de uma quantidade mínima de fibras celulósicas não dissolvidas. Para estas duas soluções, em particular, a formação de microesferas em solução coagulante ácida (Ácido Nítrico 2 M) mostrou-se possível.

O GP e $I_{c}$ calculado para a amostra $14^{\circ}$ (via análise viscosimétrica e difração de raios $X$, respectivamente) foi de 113 de $80 \%$, respectivamente. Isto indica uma redução de $84,7 \%$ no valor de GP em relação à polpa de celulose de sisal não mercerizada (GP: 743) e um aumento de $8 \%$ na cristalinidade (72\% para $80 \%$ ). TRYGG et al. (2012) reportaram uma redução de $77 \%$ no GP para uma polpa de celulose (60\% Picea / 40\% pinho) submetida ao pré-tratamento nas mesmas condições aqui utilizadas, porém com $2 \mathrm{~h}$ de duração. Em um estudo anterior, TRYGG; FARDIM (20II) demonstraram que o pré-tratamento em etanolácido (nas mesmas condições aqui empregadas) não altera, independentemente do tempo e temperatura, a quantidade de hemiceluloses presente na polpa, apontando que o aumento da solubilidade no sistema aquoso de $\mathrm{NaOH} /$ Uréia é provavelmente devido a degradação das cadeias de celulose e remoção da camada primária da parede celular (identificado via análise de FE-SEM). Assim, este tratamento na polpa de celulose em etanol-ácido permite, por meio da redução do GP (redução do tamanho médio das cadeias poliméricas), a dissolução no sistema aquoso baseado em $\mathrm{NaOH} /$ Uréia. Sem o pré-tratamento, esse sistema não é eficiente o suficiente para quebrar a estrutura da fibra e, consequentemente, atingir a dissolução total.

Assim, no presente trabalho, o pré-tratamento $14^{\circ}$ (Tabela 16) na massa celulósica (sisal) foi utilizado previamente à dissolução/formação das microesferas, desde que este foi realizado nas mesmas condições do pré-tratamento $15^{\circ}$, entretanto utilizando-se a celulose 
não mercerizada ao invés da mercerizada, o que levou a redução de um passo de prétratamento (mercerização).

\subsection{Preparação das microesferas de celulose a partir da dissolução em $\mathrm{NaOH} /$ Uréia}

Microesferas a partir de celulose de sisal pré-tratada (pré-tratamento 14², Tabela 16) e celulose microcristalina foram preparados em $7 \% \mathrm{NaOH}_{(\mathrm{aq})} / 12 \%$ Uréia. A concentração em massa de celulose em solução foi de 5,5\% e 5,0\%, respectivamente. Diferentes concentrações de ácido nítrico no meio coagulante foram consideradas $(2,4$ e $6 \mathrm{M})$ a $25^{\circ} \mathrm{C}$, assim como diferentes temperaturas $\left(50^{\circ} \mathrm{C}\right.$ e $\left.75^{\circ} \mathrm{C}\right)$ com ácido nítrico $4 \mathrm{M}$.

3.3 Determinação da área, índice de circularidade, forma, massa e porosidade total das microesferas

$\mathrm{Na}$ Tabela 17, encontram-se os valores médios de área, índice de circularidade, volume, massa e porosidade total para as microesferas de celulose de sisal e celulose microcristalina coagulados em $\mathrm{HNO}_{3}$, a $25^{\circ} \mathrm{C}$, em diferentes concentrações: 2, 4 e $6 \mathrm{M}$. 
Tabela 17 - Valores médios de área, índice de circularidade, volume, massa e porosidade total para as microesferas de celulose de sisal e celulose microcristalina preparadas em $\mathrm{NaOH}_{(\text {aq.) }} /$ Uréia e coagulados em diferentes concentrações de $\mathrm{HNO}_{3}$, a $25^{\circ} \mathrm{C}$.

\begin{tabular}{|c|c|c|c|}
\hline$\left[\mathrm{HNO}_{3}\right]$ & Sisal & Microcristalina & Propriedades \\
\hline $2 M$ & 7,516 & 7,094 & \\
\hline $4 M$ & 8,351 & 7,343 & Área $\left(\mathrm{mm}^{2}\right)$ \\
\hline $6 M$ & 7,165 & 7,145 & \\
\hline $2 M$ & 0,877 & 0,880 & \\
\hline $4 M$ & 0,876 & 0,880 & İndice de circularidade \\
\hline $6 M$ & 0,886 & 0,887 & \\
\hline $2 M$ & 13,52 & 13,55 & \\
\hline $4 M$ & 13,30 & 13,50 & Volume $\left(\mathrm{mm}^{3}\right)$ \\
\hline $6 M$ & 13,08 & 12,94 & \\
\hline $2 M$ & $\mathrm{I}, 320$ & $I,|4|$ & \\
\hline $4 M$ & $\mathrm{I}, 278$ & $\mathrm{I}, 147$ & Massa* (mg) \\
\hline $6 M$ & 1,139 & 1,136 & \\
\hline $2 M$ & 93,8 & 93,7 & \\
\hline $4 M$ & 93,9 & 89,7 & Porosidade Total (\%) \\
\hline $6 M$ & 93,6 & 93,9 & \\
\hline
\end{tabular}

* medida após secagem em estufa por $4 \mathrm{~h}$ a $105^{\circ} \mathrm{C}$. As demais propriedades correspondem à microesfera seca apenas em papel.

Analisando os dados da Tabela 17, observa-se que o aumento da concentração ácida do meio coagulante levou a um aumento da área das microesferas em um primeiro

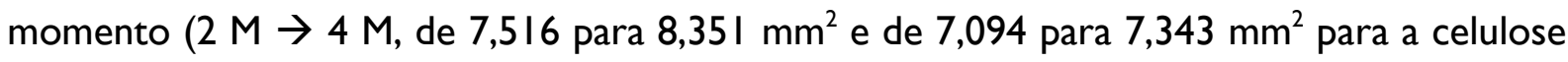
de sisal e microcristalina, respectivamente), entretanto observa-se uma redução da mesma quando a concentração ácida atinge um valor superior $\left(6 \mathrm{M}\right.$, de $8,35 \mathrm{I}$ para $7,165 \mathrm{~mm}^{2}$ e de 7,343 para $7,145 \mathrm{~mm}^{2}$ para a celulose de sisal e microcristalina, respectivamente).

Observando-se o volume das microesferas, observa-se uma redução deste ao passo que o meio coagulante de torna mais ácido, com os valores decrescendo de 13,52-13,08 $\mathrm{mm}^{3}$ para celulose de sisal e 13,55-12,94 $\mathrm{mm}^{3}$ para celulose microcristalina, quando o meio passa de 2 M para 6 M. O mesmo efeito é observado para a massa das microesferas, sendo que mais pronunciadamente para as microesferas preparadas a partir de celulose de sisal. 
Por fim, a índice de circularidade e porosidade total das microesferas de sisal aparentaram não possuírem dependência direta com a concentração ácida do meio. Os valores de índice de circularidade variaram em um intervalo estreito de $0,87-0,88$, sendo que as microesferas assumiram suas formas imediatamente após o contato da gota com o meio ácido. Quando à porosidade total, com exceção das microesferas de celulose microcristalina coagulados em ácido nítrico 4 M (89,7\%), as restantes apresentaram valores semelhantes de porosidade total, na ordem de $93,8 \%$.

Para os beads coagulados em temperaturas superiores $\left(50\right.$ e $\left.70^{\circ} \mathrm{C}\right)$, escolhendo-se $\mathrm{HNO}_{3} 4 \mathrm{M}$ como meio coagulante, os seguintes resultados foram obtidos (Tabela 18).

Tabela 18 - Valores médios de área, índice de circularidade, volume, massa e porosidade total para os beads de celulose de sisal e celulose microcristalina preparados em $\mathrm{NaOH}_{\text {(aq.) }} /$ Uréia e coagulados em ácido nítrico $4 \mathrm{M}$ a diferentes temperaturas.

\begin{tabular}{|c|c|c|c|c|}
\hline$\left[\mathrm{HNO}_{3}\right]-4 \mathrm{M}$ & $25^{\circ} \mathrm{C}$ & $50^{\circ} \mathrm{C}$ & $70^{\circ} \mathrm{C}$ & Propriedades \\
\hline Microcristalina & 7,343 & $7,25 I$ & 6,716 & Área $\left(\mathrm{mm}^{2}\right)$ \\
\hline Sisal & 8,351 & 7,556 & $* *$ & Área $\left(\mathrm{mm}^{2}\right)$ \\
\hline Microcristalina & 0,880 & 0,898 & 0,895 & İndice de circularidade \\
\hline Sisal & 0,876 & 0,869 & -- & Índice de circularidade \\
\hline Microcristalina & 13,50 & 13,37 & II,57 & Volume $\left(\mathrm{mm}^{3}\right)$ \\
\hline Sisal & 16,54 & 14,02 & -- & Volume $\left(\mathrm{mm}^{3}\right)$ \\
\hline Microcristalina & 12,96 & 14,57 & 14,12 & Massa (mg) \\
\hline Sisal & 14,52 & 16,17 & -- & Massa (mg) \\
\hline Microcristalina & $\mathrm{I}, \mathrm{I} 47$ & $\mathrm{I}, \mathrm{I} 22$ & $\mathrm{I}, 075$ & Massa* (mg) \\
\hline Sisal & $\mathrm{I}, 278$ & 1,180 & -- & Massa (mg) \\
\hline Microcristalina & 89,7 & 95,1 & 95,16 & Porosidade Total (\%) \\
\hline Sisal & 93,9 & 95,3 & -- & Porosidade Total (\%) \\
\hline
\end{tabular}

A partir dos dados na Tabela 18, observa-se que o aumento de temperatura no meio de coagulação levou a um decréscimo nos valores de área das microesferas, assim como nos valores de volume. Por outro lado, os valores de massa das microesferas secas em papel 
(ainda intumescidas) aumentaram com o aumento de temperatura, enquanto que os valores de massa das microesferas, após secagem em estufa, decresceram. Este fato pode ser explicado ao se analisar os valores de porosidade total das microesferas, propriedade a qual aumenta conforme se aumenta o valor de temperatura do meio coagulante, indicando uma maior presença de micro e pequenos mesoporos a $25^{\circ} \mathrm{C}$ e macroporos a $50{ }^{\circ} \mathrm{C}$ e $70^{\circ} \mathrm{C}$. Este fato foi também descrito por TRYGG et al. (20I2), em um estudo que mostrou o aumento na presença de macroporos $(560 \AA$ ) em relação à mesoporos (39 $\AA$ ), conforme o aumento da acidez do meio coagulante, na obtenção de microesferas de celulose. Em baixas concentrações ácidas, a coagulação é mais lenta e a celulose tem mais tempo para se rearranjar e formar cavidades menores, enquanto que, com o aumento da acidez do meio, a coagulação mais rápida propicia a formação de macroporos.

Desde que microesferas mais porosas (com maior presença de macroporos) podem armazenar maior quantidade de água inclusa (coagulados a $50^{\circ} \mathrm{C}$ e $70^{\circ} \mathrm{C}$, maior porosidade, Tabela 18), espera-se que a massa destas, ainda intumescidas seja maior, devido à presença de uma maior quantidade de água internamente a estrutura da micropartícula. Em contrapartida, observa-se que a massa final das microesferas (após secagem) vai em direção oposta ao que seria esperado, desde que uma maior quantidade de água foi perdida naquelas microesferas mais porosas, as quais apresentaram maior massa enquanto intumescidas. Assim como anteriormente, não foram observadas diferenças significativas nos valores de índice de circularidade para as microesferas de celulose de sisal e celulose microcristalina.

\subsection{FE-SEM}

As mudanças morfológicas nas superfícies dos beads de celulose de sisal e celulose microcristalina coagulados em ácido nítrico (2, 4 e $6 \mathrm{M}$ ) foram estudados via FE-SEM (Figura 70). As ampliações foram realizadas com magnificações da ordem de 10000x sobre as superfícies de microesferas individuais. 
Figura 70 - Micrografias das superfícies das microesferas de celulose de sisal e celulose microcristalina preparadas em $\mathrm{NaOH}_{(\mathrm{aq} .)} /$ Uréia e coagulados em diferentes concentrações de $\mathrm{HNO}_{3}$.
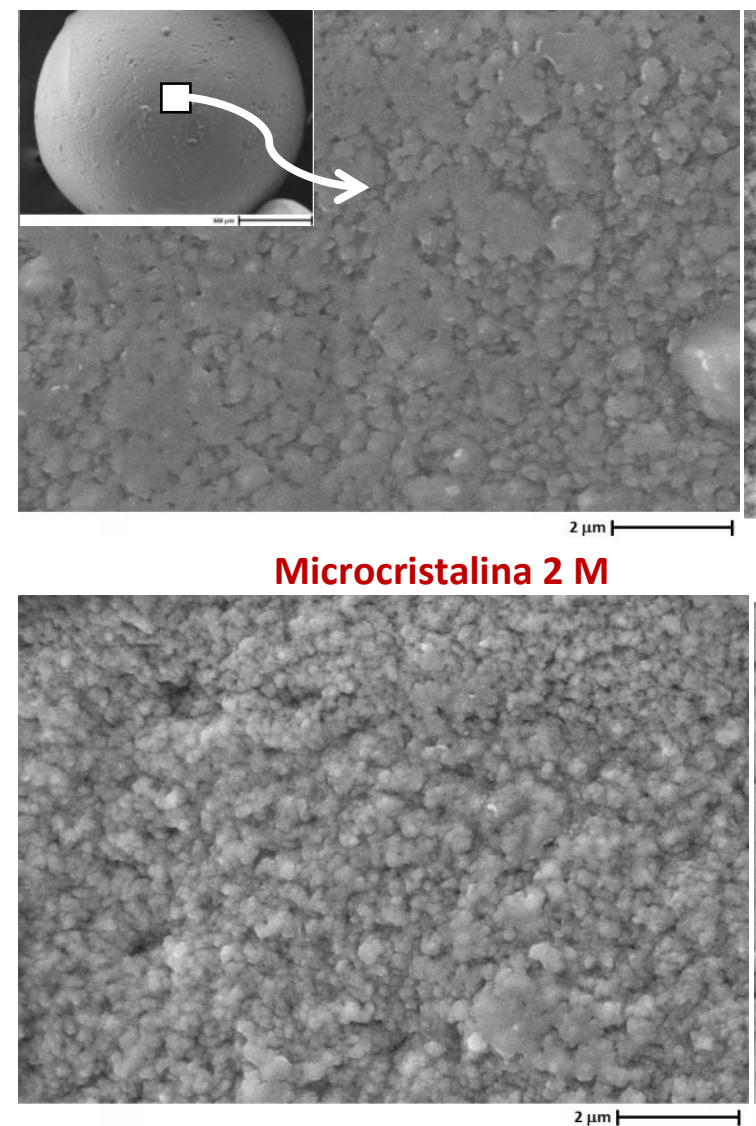

Microcristalina $4 \mathrm{M}$

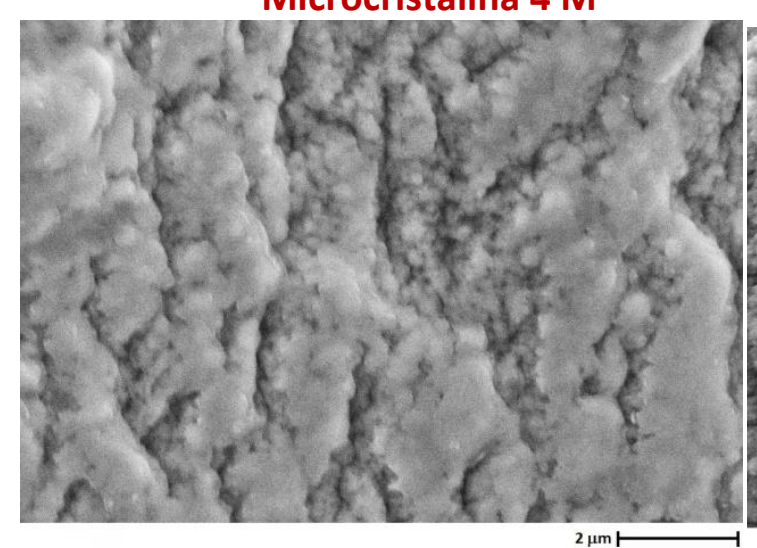

Microcristalina $6 \mathrm{M}$

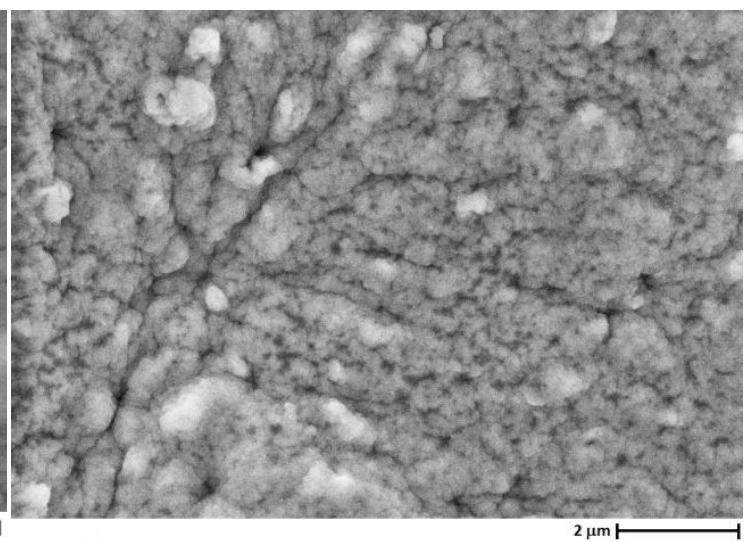

Sisal 2 M

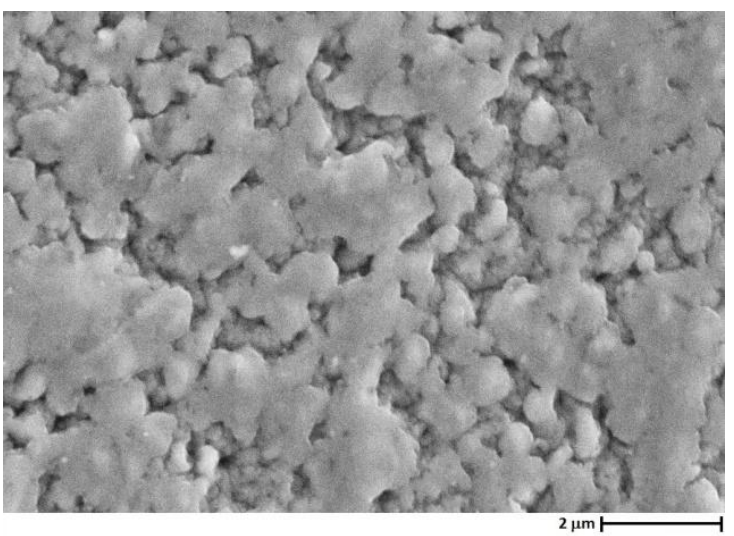

Sisal $4 \mathrm{M}$

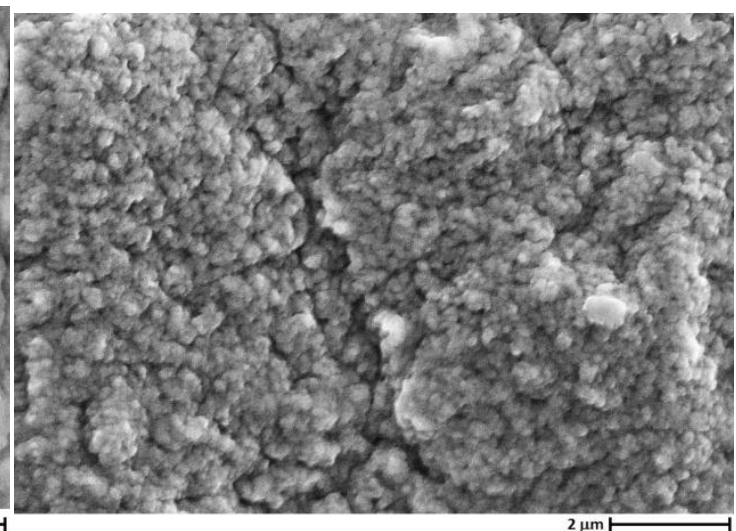

Sisal $6 \mathrm{M}$

Pode-se observar que com o aumento da concentração ácida no meio coagulante, microesferas com superfícies mais rugosas foram obtidos (Figura 70). Observa-se para as microesferas obtidas em $\mathrm{HNO}_{3} 2 \mathrm{M}$, a ausência de amplas cavidades e agregados aponta em direção de que a agregação continuou a formar estruturas mais sólidas (compactas) após o primeiro contato com a solução coagulante, ou que a coagulação procedeu via outro 
mecanismo. Com o aumento da concentração ácida do meio coagulante, amplas cavidades (Microcristalina $4 \mathrm{M}$ e Sisal $4 \mathrm{M}$ ), assim como regiões com aspectos mais fibrosos (Microcristalina $6 \mathrm{M}$ e Sisal $6 \mathrm{M}$ ) são observadas. Este fato aponta que a rápida coagulação, ocorrida nos meios mais concentrados, pode ter sido responsável por "desacelerar" a agregação das fibrilas de celulose após o primeiro contato com o meio ácido, resultando nestas estruturas (Trygg et al., 20l I).

As mudanças morfológicas nas superfícies dos microesferas de celulose de sisal e celulose microcristalina coagulados em ácido nítrico $4 \mathrm{M}$, em diferentes temperaturas, foram também investigadas via FE-SEM (Figura 7I). As ampliações foram realizadas com magnificações da ordem de 10000x sobre as superfícies de microesferas individuais. 
Figura 7I - Micrografias das superfícies das microesferas de celulose de sisal e celulose microcristalina preparadas em $\mathrm{NaOH}_{(\text {aq.) }}$ /Uréia e coaguladas em diferentes temperaturas em $\mathrm{HNO}_{3} 4 \mathrm{M}$.

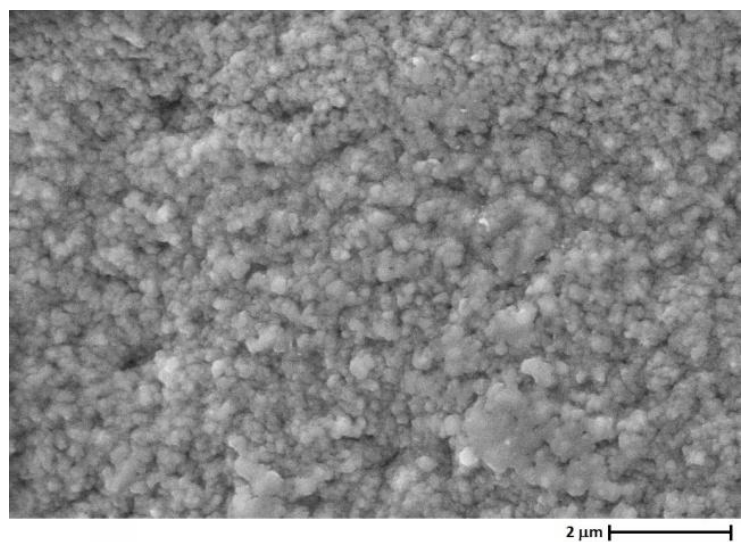

Microcristalina $4 \mathrm{M}-25^{\circ} \mathrm{C}$

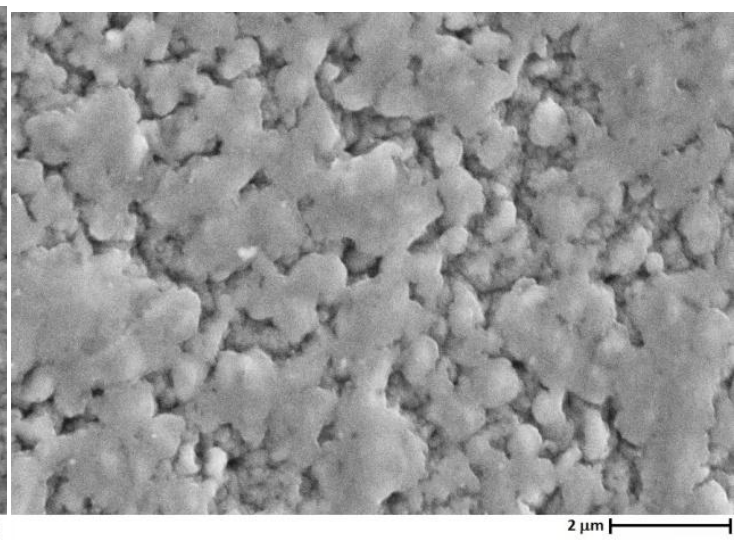

Sisal $4 \mathrm{M}-25^{\circ} \mathrm{C}$

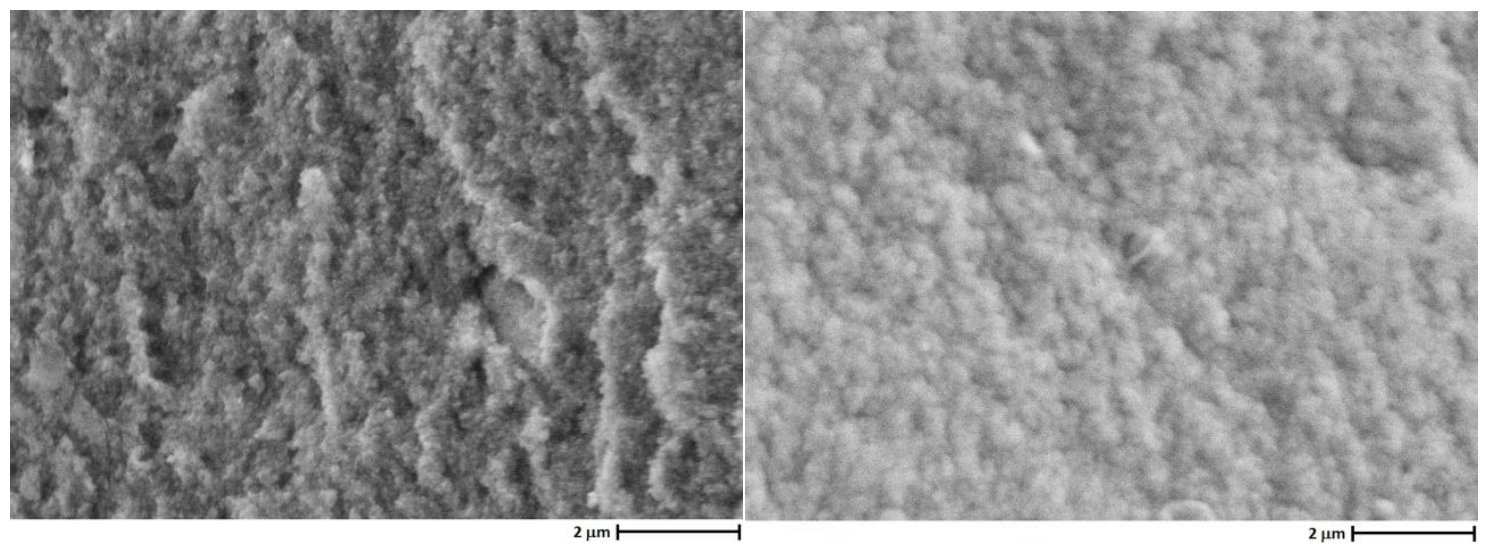

Microcristalina $4 \mathrm{M}-50^{\circ} \mathrm{C}$ Sisal $4 \mathrm{M}-50^{\circ} \mathrm{C}$

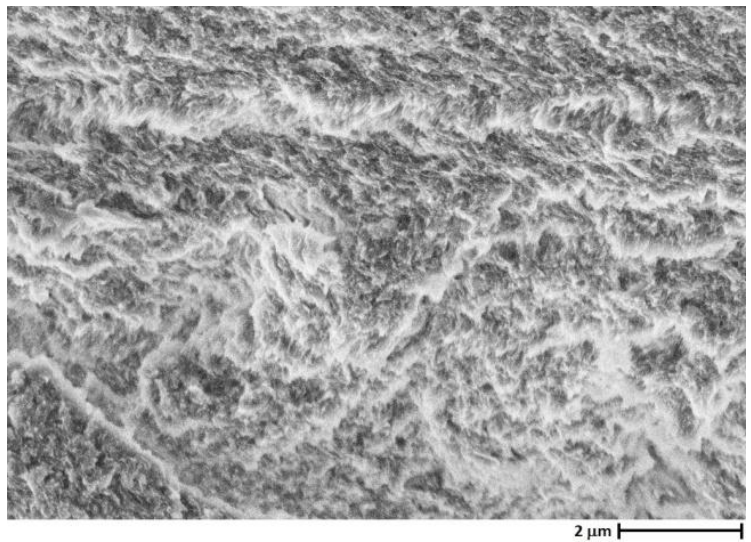

Microcristalina $4 \mathrm{M}-70^{\circ} \mathrm{C}$

Pode-se observar que com o aumento da temperatura do meio coagulante, houve o aumento da rugosidade superficial das microesferas de celulose de sisal e microcristalina (Figura 7I). Para as microesferas de celulose de sisal, observa-se que a coagulação a $50^{\circ} \mathrm{C}$ levou a uma superfície mais compacta e homogênea, com menos cavidades. Desde que o 
aumento na temperatura proporciona uma coagulação mais rápida, provavelmente o tempo para fusão das fibrilas foi também diminuído, levando a uma redução no tamanho destas. Ademais, o aumento da temperatura de coagulação pode ter sido responsável por interceptar a agregação, consequentemente resultando em fibrilas e estruturas mais finas.

\subsection{Avaliação da resistência das microesferas após aplicação de força centrífuga}

Esta análise, a qual visou analisar os efeitos de diferentes velocidades de centrifugação nas propriedades das microesferas de celulose de sisal (área, volume e índice de circularidade), foi desenvolvida no grupo de pesquisa no qual a parte do projeto contida neste Capítulo foi desenvolvida (Åbo Akademi University - Laboratory of Fibre and Cellulose Techonology). Esta análise consistiu da centrifugação dos beads em diferentes velocidades (1000-4000 rpm), avaliando-se a forma e tamanho das microesferas previamente a após cada experimento. A Figura 72 apresenta as alterações ocorridas nestas propriedades, nas diferentes velocidades, para as microesferas de celulose de sisal.

Para o intervalo de centrifugação considerado, não houve alteração significativa nestas propriedades para os beads de celulose microcristalina. 
Figura 72 - Efeito de diferentes velocidades de centrifugação na área, volume e índice de circularidade das microesferas de celulose de sisal.
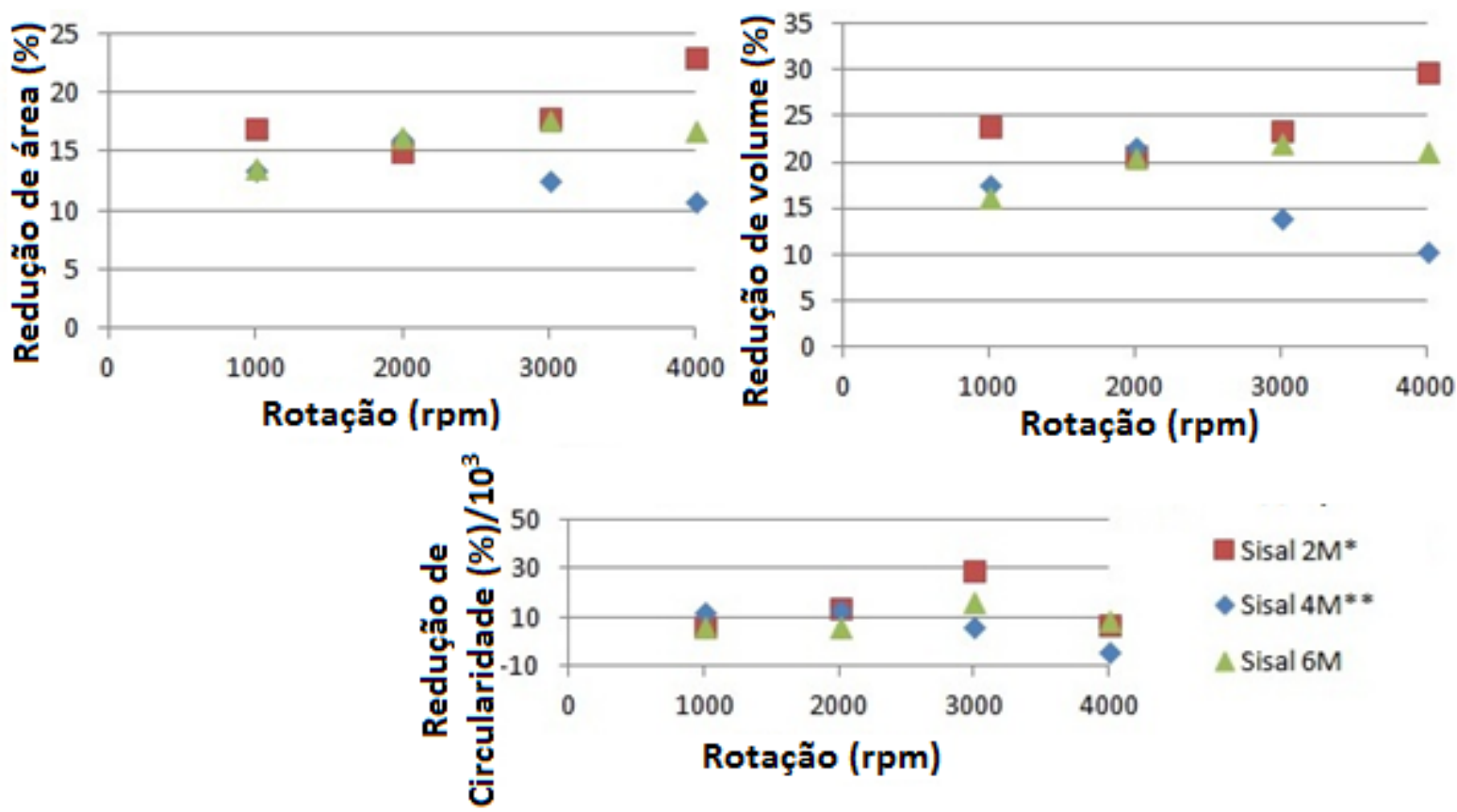

* 50\% das microesferas foram destruídos após a centrifugação a 3000-4000 rpm.

** 30\% das microesferas foram destruídos após a centrifugação a 3000-4000 rpm.

Ao se analisar os gráficos da Figura 72, observa-se que apenas para $\circ$ caso das microesferas coaguladas em ácido nítrico $6 \mathrm{M}$, não houve destruição de parte dos mesmos durante os experimentos. Ademais, observa-se que, para estas microesferas, a redução do volume (16-22\%) e da área (13-18\%) aumentou (com uma ligeira estabilização no intervalo de 3000-4000 rpm) conforme se aumentou a velocidade de centrifugação. Os valores de índice de circularidade mostraram não variar significantemente no intervalo apresentado. Estes resultados demonstram que, para o caso destas microesferas preparadas em $\mathrm{HNO}_{3}$ $6 \mathrm{M}$, estas propriedades (volume e área) são direta e proporcionalmente afetadas conforme se aumenta a "agressividade do teste" (maiores velocidades). Entretanto, há provavelmente uma distribuição equitativa de forças ao longo dos eixos, não afetando significativamente a índice de circularidade.

Para o caso das microesferas coaguladas em $2 \mathrm{M}$ e $4 \mathrm{M}$, a análise se torna um pouco mais complexa. Observa-se que para 1000-2000 rpm, onde não há a destruição de parte das microesferas, a redução de área e volume para as microesferas coaguladas em $4 \mathrm{M}$ acompanha o intervalo encontrado para $6 \mathrm{M}$, enquanto para as microesferas coaguladas em $2 \mathrm{M}$ a redução inicial (1000 rpm) de volume/área é maior, encontrando-se em um ponto 
comum (2000 rpm) com 4 M e 6 M. Em 3000-4000 rpm, observa-se que há uma menor redução de área/volume para as microesferas coaguladas em $4 \mathrm{M}$, enquanto observa-se uma maior redução destas propriedades para as microesferas coaguladas em $2 \mathrm{M}$. Este resultado é muito interessante, visto que no intervalo de 3000-4000 rpm, onde houve a destruição parcial das microesferas, pode-se considerar que apenas as microesferas de maior resistência permaneceram (dentre a amostragem considerada).

Estes resultados apontam na direção de que com o aumento da acidez do meio coagulante, microesferas mais resistentes são obtidas: (I) para $6 \mathrm{M}$ não houve destruição dos beads no intervalo de 1000-4000 rpm, apresentando as curvas sempre nos intervalo médio entre 2 M e $4 \mathrm{M}$; (2) para $2 M$ houve a maior redução inicial (1000 rpm) de área/volume; (3) após a destruição parcial das microesferas, observa-se uma menor redução de área/volume/índice de circularidade para as microesferas em $4 \mathrm{M}$ em relação a $2 \mathrm{M}$.

O próximo capítulo (Capítulo 5) abordará um estudo sobre a eletrofiação da fibra lignocelulósica de sisal, e da celulose extraída a partir dela, visando à obtenção de fibras na escala submicrométrica e nanométricas. 


\section{Breve Sumário e Conclusões Parciais}

Neste estudo, abordou-se a preparação de microesferas a partir da dissolução de celulose de sisal em sistema aquoso composto por $\mathrm{NaOH} /$ Uréia, seguido de coagulação em meio ácido. Devido ao GP da polpa celulósica de sisal usada neste trabalho se mostrar elevado o suficiente para impedir a dissolução das fibras em concentração adequada para posterior coagulação, a busca de um pré-tratamento na massa celulósica foi necessário previamente a preparação das microesferas. Após testar diversas condições de tratamento, condições ótimas foram atingidas na dissolução/coagulação das fibras, a partir do prévio tratamento da celulose em sistema etanol-ácido $\left(\mathrm{HCl} 37 \%, 4 \%\right.$ em massa, $\left.3 \mathrm{~h}, 75{ }^{\circ} \mathrm{C}\right)$. Utilizou-se sistema aquoso baseado em $12 \% \mathrm{NaOH}_{(\mathrm{aq} .)} / 7 \%$ Uréia como solvente e ácido nítrico em diferentes concentrações ácidas como meios coagulantes.

Com o aumento da concentração ácida do meio coagulante (ácido nítrico, 2 M para $4 \mathrm{M}$ e $6 \mathrm{M}$ ), verificou-se a formação de microesferas com superfícies mais rugosas. Efeito similar foi observado em concentração ácida constante $(4 M)$ e consequente aumento de temperatura do meio coagulante (ácido nítrico $4 \mathrm{M}$ a $25-70^{\circ} \mathrm{C}$ ). Resultados de avaliação de resistência, via aplicação de força centrífuga, apontaram na direção da obtenção de microesferas mais resistes com o aumento da acidez do meio coagulante.

A preparação de microesferas a partir de celulose de sisal vêm em direção à aplicação destes materiais nos mais diversos campos (como na liberação controlada de fármacos, cromatografia, dentre outros). A partir deste estudo, pode-se mostrar que apesar

No próximo capítulo (Capítulo 5) será descrito um estudo sobre a eletrofiação da fibra lignocelulósica de sisal, e da celulose extraída a partir dela, visando à obtenção de fibras na escala submicrométrica e nanométricas. 


\section{CAP 5. ELETROFIAÇÃO DA FIBRA LIGNOCELULÓSICA DE SISAL E SEUS DERIVADOS}

\section{Introdução}

Neste último capítulo, relata-se a utilização de uma técnica recentemente introduzida no Grupo de Pesquisa no qual este trabalho foi desenvolvido, conhecida como eletrofiação (electrospinning). Esta técnica permitiu que, a partir da fibra lignocelulósica de sisal ou seu componente principal, a celulose, fibras na escala nano (fibras < $100 \mathrm{~nm}$ ) e micro $(100 \mathrm{~nm}<$ fibras $<1000 \mathrm{~nm}$ ) fossem obtidas a partir de soluções desses materiais. Destaca-se que a obtenção de fibras nesta escala, a partir de uma fibra lignocelulósica não previamente tratada, teve caráter inédito, até onde atinja o nosso conhecimento. Ademais, esses resultados abriram novos caminhos para que esse método começasse a ser utilizado em outros trabalhos de pesquisa do Grupo, no qual membranas (mats) de polímeros termoplásticos têm sido preparadas via técnica de eletrofiação, com reforço da fibra lignocelulósica (DE OLIVEIRA SANTOS et al., 2013).

\section{I.I Definição de nanofibras}

A terminologia normativa definida pela ISO publicada no final de Setembro/2008, sob o número ISO / TS 27687 ("Nanotechnology - terminology and definitions for the "nanoobjects", i.e., Nanoparticle, nanofiber and nanoplate") (Figura 73), pode ser usada para a definição de "nano-objetos":

(i) Definição de nano como sendo o intervalo de dimensão entre $\mathrm{I}$ e $100 \mathrm{~nm}$.

(ii) Objetos nano são materiais com uma, duas ou três dimensões no domínio nano. 
Figura 73 - Diagrama esquemático mostrando algumas formas para nano-objetos.

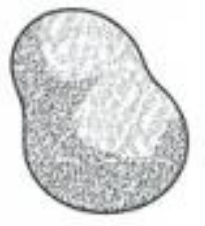

a) nanopartícula

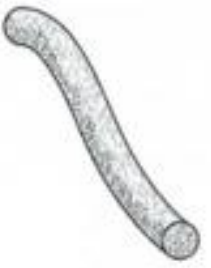

b) nanofibra

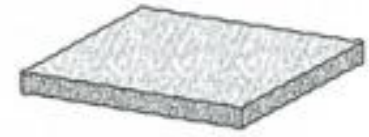

c) nanoplaca

Dentre estes nano-objetos, nanopartículas [Figura 73-(a)] são nanomateriais que contêm as suas três dimensões no campo de nano; "nanoplacas" [Figura 73-(c)] contêm uma dimensão na escala nano, enquanto nanofibras [Figura 73-(b)] são nano objetos com duas dimensões na escala nano, com a terceira dimensão sendo significantemente superior.

Aplicando-se as especificações técnicas ISO (ISO/TS 27687 e ISO/TS 80004-I) e o relatório técnico ISO (ISO/TR II360), alguns conceitos e definição podem ser estabelecidos para os materiais celulósicos, entre eles são destacados:

(i) Cellulose Nanomaterial (Nanomaterial a partir de celulose): Nanomaterial a partir de celulose é uma classe de materiais que contém objetos celulósicos em escala nano. Nesta classe, são compreendidos os nanocristais de celulose (CNC), nanofibrila de celulose (CNF), microcristal de celulose (CMC) e microfibrila de celulose (CMF). A relação hierárquica para estes termos são designados no esquema apresentado na Figura 74. 
Figura 74 - Termos padrões utilizados para nanomateriais celulósicos (ISO/TS 27687).

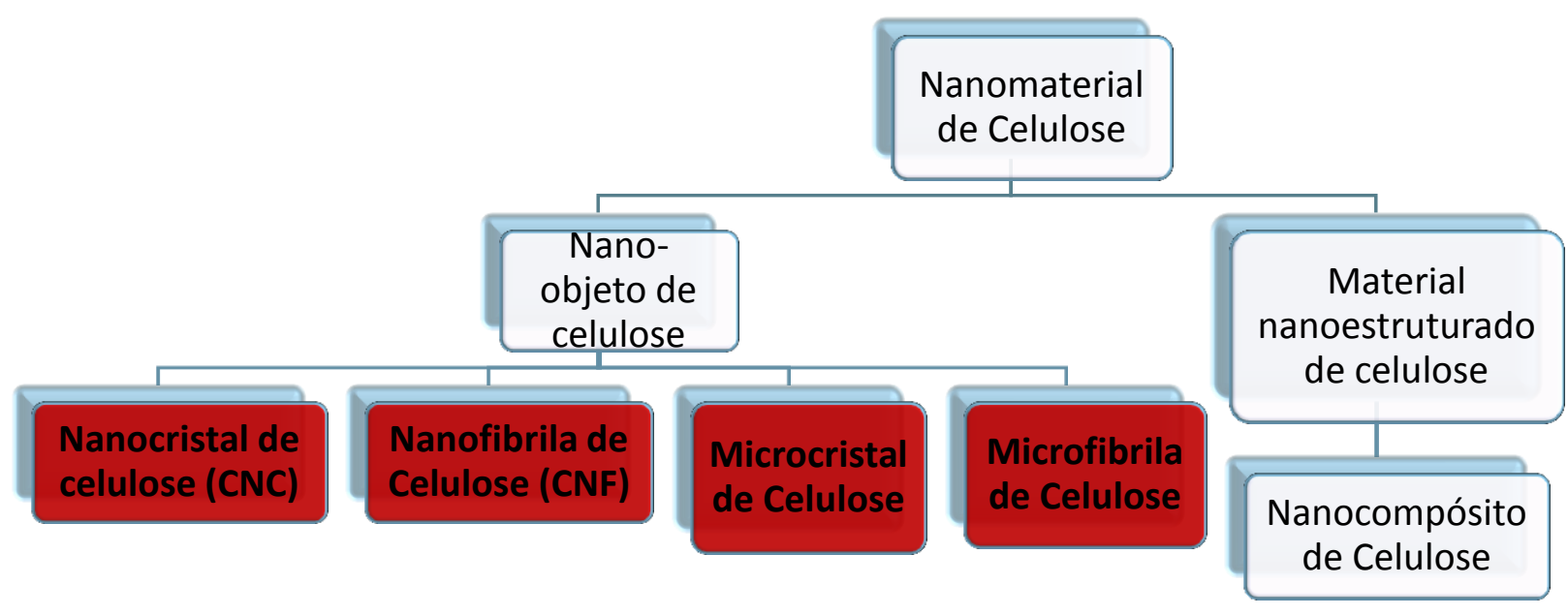

(ii) Nanocristal de Celulose (CNC): Em forma de haste ou "whisker" ("bigode"), consiste em nanofibras celulósicas remanescentes após hidrólise ácida de polpa de madeira, fibras de plantas não oriundas de madeira, microfibrilas de celulose, nanofibrilas de celulose (ISO/TS 80004-I). CNCs, no geral, possuem alta razão de aspecto (relação entre comprimento e largura), com espessuras no intervalo de 3-5 nm e comprimento na faixa de $50-500 \mathrm{~nm}$, e alto grau de cristalinidade (ISO/TS 80004-I).

(iii) Nanofibrila de celulose (CNF): nanofibra de celulose produzida quando técnicas específicas são incorporadas no refinamento mecânico de fibras de madeira e fibras de plantas não oriundas da madeira. CNF's, no geral, possuem alta razão de aspecto, com espessuras no intervalo de 4-20 nm e comprimento na faixa de 500-2000 nm, e alto grau de cristalinidade (ISO/TS 80004-I).

(iv) Microfibrila de celulose (CMF): Material celulósico geralmente considerado por conter múltiplas fibrilas elementares. Possui uma alta razão de aspecto com 10-100 nm de espessura, 0,5-10 $\mu \mathrm{m}$ de comprimento, usualmente produzido via refinamento mecânico de polpa de madeira altamente purificada ou polpa de plantas não oriundas de madeira (ISO/TS 80004-I). 
Microcristal de celulose (CMC): Material celulósico poroso nanoestruturado,

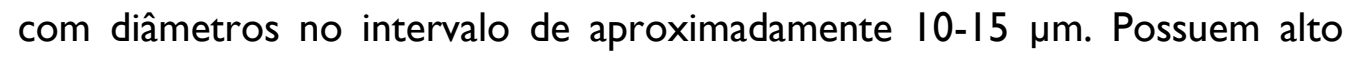
grau de cristalinidade e são compostos por feixes agregados de microfibrilas de celulose (escala nanométrica), usualmente produzidos por hidrólise ácida de polpa de madeira (ISO/TS 80004-I).

É importante que estes critérios sejam de amplo conhecimento, principalmente no campo científico, no qual milhares de trabalhos são divulgados anualmente. No presente trabalho, as fibras com espessuras no intervalo de $100 \mathrm{~nm}-1000 \mathrm{~nm}$ foram referenciadas como fibras ultrafinas, como adotado por alguns autores (HUANG et al., 2003; SON et al., 2004a). Nas seções a seguir, será abordada a importância na obtenção e estudo destes materiais em escalas $<1000 \mathrm{~nm}$, assim como os principais métodos de obtenção.

\section{I.2 Fibras ultrafinas e nanofibras}

A redução do diâmetro de materiais poliméricos fibrosos da escala micrométrica

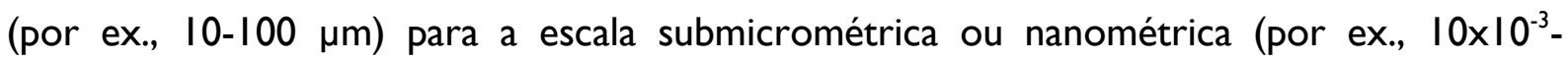
$100 \times 10^{-3} \mu \mathrm{m}$, respectivamente) é responsável por gerar $\circ$ aparecimento de propriedades muito especiais. Entre estas propriedades, cita-se $\circ$ aumento da área de superfície em relação ao volume (para uma nanofibra, esta razão pode ser $10^{3}$ vezes maior em relação a sua microfibra), flexibilidade nas funcionalidades de superfície, aumento nos valores de condutividade elétrica e térmica e desempenho mecânico superior (como rigidez e resistência à tração), quando comparado com qualquer outra forma do mesmo material. Estas propriedades apresentadas, assim como muitas outras, tornam estes materiais excelentes candidatos para aplicação em diversos campos, objetivando a obtenção de novos materiais ou mesmo o aperfeiçoamento de materiais já existentes (ZHUANG et al., 2014).

Nos últimos anos, a produção de nanofibras e/ou fibras ultrafinas tem sido possível por inúmeras técnicas, tais como fiação (LIU; OUYANG; XIAO, 20I2), separação de fases (MA; ZHANG, 1999), automontagem (WHITESIDES; GRZYBOWSKI, 2002), síntese template (FENG et al., 2003; TAO; DESAl, 2007; BHOWMICK et al., 20I2), eletrofiação (electrospinning) (HUANG et al., 2003; LI; XIA, 2004; OCHANDA et al., 20I2; GAO et al., 
20I4), dentre outras. Todas as técnicas mencionadas contêm inúmeras e individuais particularidades, tais como a possibilidade de obtenção de nanofibras individuais longas (fiação), obtenção de túbulos e fibrilas nanométricas a partir de diversos materiais, como polímeros condutores, metais, semicondutores podem ser fabricados (síntese template), entre outros exemplos.

Muitos processos têm sido usados para a obtenção de nanofibras e fibras ultrafinas a partir de materiais celulósicos (Tabela 19). Todos esses métodos levam a diferentes tipos de materiais nanofibrilares, dependendo da matéria-prima da celulose e seu pré-tratamento, e mais importante, dependendo do tipo de processo.

Tabela 19 - Processos para a produção ou extração de nanofibras e fibras ultrafinas de celulose altamente purificadas.

\begin{tabular}{|c|c|}
\hline Processo de extração e métodos & Referências \\
\hline Tratamentos mecânicos (ex, trituração criogênica) & (THIRIPURA SUNDARI; RAMESH, 20I2) \\
\hline Moagem & (NOGI et al., 2009; ABE; YANO, 20I0) \\
\hline Tratamentos químicos (ex, hidrólise) & (LIU; DU, 20I2) \\
\hline $\begin{array}{l}\text { Tratamentos biológicos, ex: hidrólise assistida por } \\
\text { enzimas }\end{array}$ & (AL-ABDALLAH; DAHMAN, 2013) \\
\hline $\begin{array}{l}\text { Oxidação da superfície de microfibrilas mediado } \\
\text { por TEMPO ( } N \text {-oxil-2,2,6,6-tetrametilpiperidina) e } \\
\text { subsequente tratamento mecânico }\end{array}$ & (SAITO et al., 2009; IWAMOTO et al., 20I0) \\
\hline Métodos sintéticos e de eletrofiação & $\begin{array}{l}\text { (BHOWMICK et al., 20I2; OCHANDA et al., } \\
2012 \text { ) }\end{array}$ \\
\hline Técnica ultrassônica & (CHENG; WANG; HAN, 20I0) \\
\hline
\end{tabular}

Dentre as técnicas apresentadas, a eletrofiação demonstra ser, até agora, o único método para a produção em massa de fibras ultrafinas contínuas, a partir de uma vasta gama de polímeros. 


\section{I.3 Eletrofiação (electrospinning)}

A técnica de eletrofiação (electrospinning) tem sido reconhecida nos últimos anos como uma das mais eficientes no preparo de fibras ultrafinas e nanofibras, como descrito em milhares de trabalhos relatados na literatura. Como abordado anteriormente, a redução do diâmetro da fibra polimérica da escala micrométrica para nanométrica exerce grande influência nas propriedades da fibra, principalmente em suas propriedades mecânicas. As fibras eletrofiadas possuem uma grande área de superfície, com potencial de aplicação em uma vasta gama de áreas, desde produção de vestuários de proteção (RAMAKRISHNA; RAMASESHAN, 2008), cosméticos. (GHOLAMI; TAVANAI; MORADI, 20II), até áreas como liberação controlada de drogas (WANG et al., 20I2), aplicações biomédicas (VIJU, 2009; KROGSTAD; WOODROW, 20I4) e preparação de compósitos (MAHAPATRA et al., 20I2; MARTÍNEZ-SANZ et al., 20I2; KIM; KIM, 20I4).

O princípio geral de operação da técnica de eletrofiação é relativamente simples: fibras ultrafinas são produzidas, com diâmetros que variam desde $100 \mathrm{~nm}$ (ou menos, caracterizando nanofibras) até $1000 \mathrm{~nm}$ (ou mais), a partir da aplicação de um campo eletroestático de alta voltagem ( $1-45 \mathrm{kV}$, usualmente), o qual é operado entre uma agulha metálica (de diâmetro variável) e um coletor metálico. A Figura 75 apresenta um equipamento de eletrofiação (IME Technologies), de modelo idêntico ao usado neste trabalho.

Figura 75 - Equipamento utilizado no processo de eletrofiação'

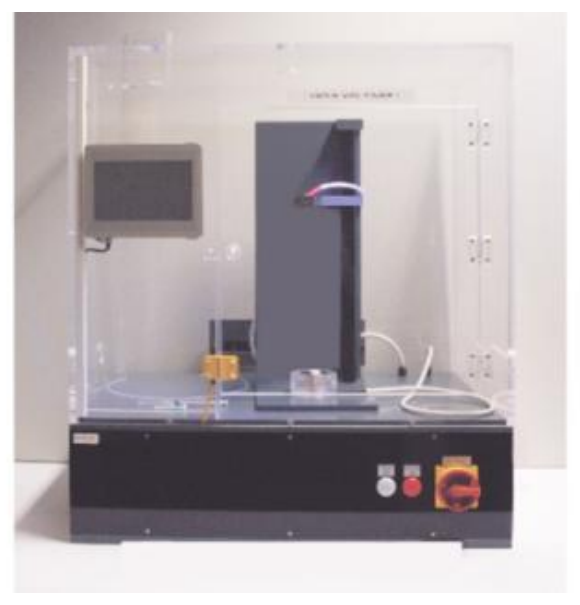

\footnotetext{
${ }^{1}$ Disponível em http://www.imetechnologies.nl/Electrospinning-Apparatus-n263m338, acesso em 18/02/2012.
} 
Uma grande quantidade de trabalhos envolvendo a técnica de eletrofiação tem sido desenvolvida nos últimos 20 anos (Figura 76, I4.388 ocorrências para o termo “electrospinning" na base de dados SCOPUS, no período de 1994 a Outubro/2014).

Figura 76 - Número de trabalhos publicados e indexados na base de dados SCOPUS no período de 1993 a 201 I contendo "electrospinning" como palavra-chave.

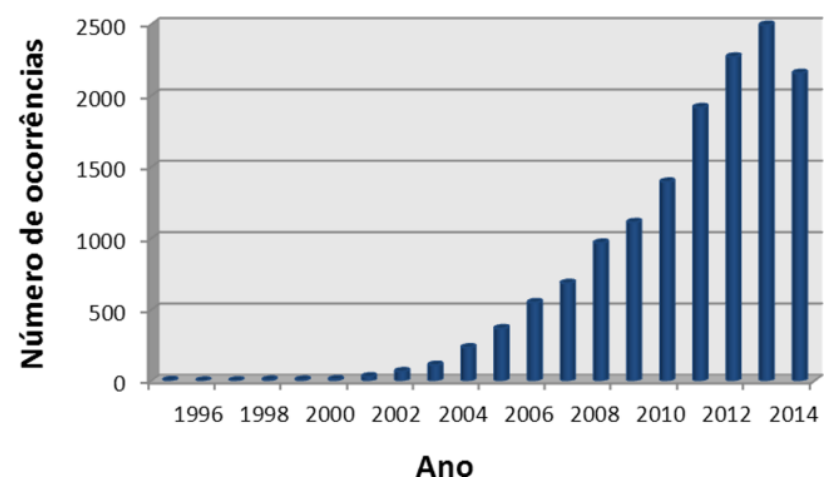

Dentre os 15.000 trabalhos publicados durante este período, as contribuições majoritárias se encontram dentro das áreas de Ciência dos Materiais, Engenharia, Engenharia Química e Química (Figura 77). Estes números vêm a comprovar a enorme potencialidade desta técnica para a produção e caracterização de novos materiais.

Figura 77 - Divisão dos trabalhos publicados por área de publicação, no período de 199420 I4, para o termo "electrospinning" na base de dados SCOPUS.

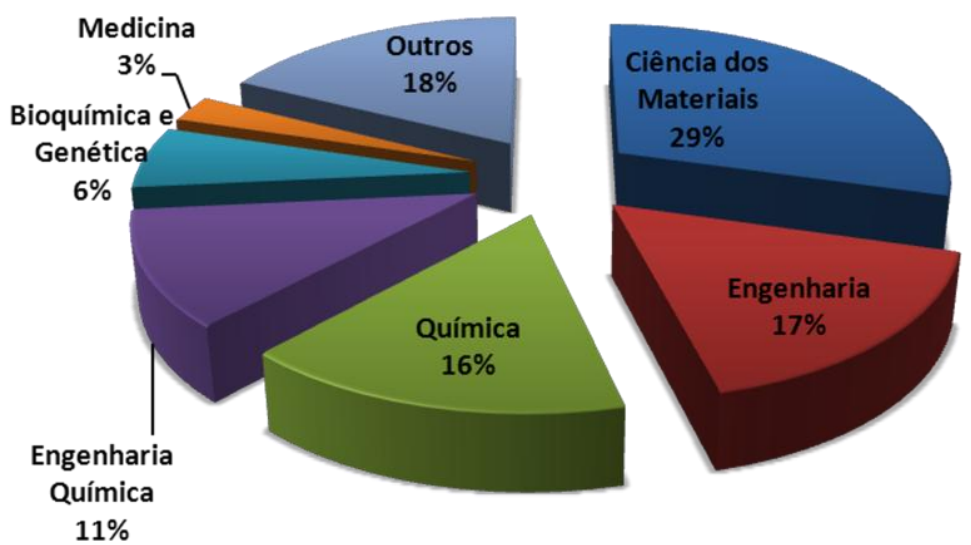

Ademais, verifica-se que, no decorrer dos últimos 15 anos, entre o período de 2000 a 20I5, houve um aumento na ordem de mais de 50 vezes no número de publicações, com um indicativo de que, nos próximos anos, ainda milhares de trabalhos serão publicados utilizando a técnica de eletrofiação na produção de novos materiais. 


\section{I.3.I Fundamentos da técnica de eletrofiação}

Em termos gerais, a técnica de eletrofiação pode ser descrita por três componentes básicos para a realização de todo o processo: (I) fonte de alta voltagem, (2) tubo capilar com uma pipeta ou agulha com diâmetro muito pequeno e (3) coletor metálico (Figura 78).

Figura 78 - Representação esquemática do funcionamento da técnica de eletrofiação.

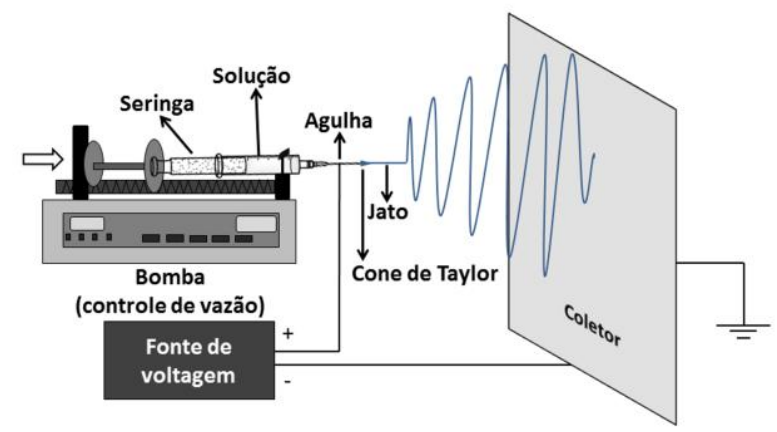

A técnica de eletrofiação pode ser aplicada a soluções poliméricas ou mesmo a polímeros fundidos, a depender da configuração do equipamento. Na técnica de eletrofiação, a elevada voltagem aplicada é usada para criar um jato de solução polimérica eletricamente carregada, ou para fundir o polímero pela pipeta ou agulha. Assim, antes de atingir o coletor, ocorre a evaporação do solvente no jato de solução ou a solidificação do polímero fundido, e o polímero é coletado como uma rede interconectada de fibras. Um eletrodo é colocado dentro da solução de fiação/polímero fundido ou, alternativamente, em contato com a ponta da agulha onde está presente a solução polimérica, enquanto outro eletrodo é colocado no coletor. A extremidade do tubo capilar, que contém a solução polimérica mantida pela sua tensão superficial, é submetida ao campo elétrico, induzindo carga na superfície do líquido. Um jogo de forças, no qual age a repulsão mútua de cargas e a contração das cargas superficiais para o contra-eletrodo, gera uma força diretamente oposta à tensão superficial (FANG; RENEKER, 1997). Enquanto a intensidade do campo elétrico é aumentada, a superfície hemisférica do fluido no tubo capilar (ou agulha) se alonga, de forma a adquirir uma superfície cônica, conhecida como o cone de Taylor (MELCHER; TAYLOR, 1969). Ainda, com o aumento do campo elétrico, este pode adquirir um valor crítico, no qual a força de repulsão eletroestática supera a tensão superficial e o jato de fluído carregado é ejetado do cone de Taylor. $O$ jato de solução polimérica descarregada passa por um 
processo de instabilidade e alongamento, o qual permite que este se torne muito longo e fino. Enquanto isso, o solvente evapora, deixando para trás uma fibra polimérica carregada. No caso da massa fundida, o jato descarregado se solidifica enquanto se desloca pelo ar.

$\mathrm{Na}$ eletrofiação de soluções poliméricas, com exceções de equipamentos com adaptações especiais, o processo de eletrofiação é conduzido à temperatura ambiente, sob condições atmosféricas. Entretanto, em virtude da volatilidade e potencial toxicidade de alguns solventes ou mesmo polímeros utilizados, é extremamente aconselhável que os processos sejam conduzidos dentro de câmeras especiais, com sistemas de ventilação. Além disso, uma fonte de tensão com um alto intervalo de $\mathrm{kVs}$ é necessária, tornando necessário que haja um grande cuidado para evitar o contato com o jato carregado durante a manipulação ou mesmo a geração de faíscas, que podem causar danos à integridade das membranas eletrofiadas.

A princípio, quase todos os polímeros solúveis ou passíveis de fusão podem ser processados em fibras através da técnica de eletrofiação, desde que parâmetros tais como solubilidade, temperatura de transição-vítrea, temperatura de fusão, velocidade de cristalização, massa molecular média, distribuição de massa molecular, densidade de ramificações (se presente), pressão de vapor do solvente (no caso de soluções) e valor de $\mathrm{pH}$ (no caso de soluções aquosas ou ácido/base) e os parâmetros de processo (tais como concentração, condutividade elétrica, tensão superficial, taxa de alimentação da solução, separação do eletrodo e geometria, temperatura e umidade relativa) sejam conhecidos para que condições possam ser corretamente ajustadas (GREINER; WENDORFF, 2007).

Em geral, observa-se que as fibras se tornam mais uniformes e assumem uma forma cilíndrica com o aumento da concentração da solução; os diâmetros das fibras também aumentam significativamente com $\bigcirc$ aumento da concentração do polímero. Em concentrações mais baixas, a formação de fibras mais finas é favorecida, entretanto pode-se começar a observar a presença de beads (gotas) ao longo do eixo das fibras; em diluições ainda maiores, a formação de fibras já não mais acontece. A formação de beads pode ser prevenida pelo aumento da condutividade elétrica da solução, que favorece fibras com diâmetros na ordem de poucos nanômetros (FONG; CHUN; RENEKER, 1999).

As viscosidades apropriadas para soluções variam tipicamente de dezenas a centenas de millipascals por segundo, e as condutividades elétricas em solventes orgânicos variam 
tipicamente de nano à microsiemens por centímetro. A morfologia das fibras visando à forma cilíndrica pode também ser direcionada pela escolha apropriada do sistema de solvente (solventes com alto ponto de ebulição/baixo ponto de ebulição) (FONG; CHUN; RENEKER, 1999).

Dentre os principais "defeitos" associados às fibras pós eletrofiação, a presença de beads ao longo do eixo é corriqueiramente relatada em diversos estudos, sendo geralmente associada à instabilidade do jato da solução polimérica (FONG; CHUN; RENEKER, 1999), a qual foi um assunto extensivamente estudado por ENTOV; SHMARYAN (1997). Neste estudo, são indicados os principais fatores que levam a formação dos beads como sendo a viscosidade da solução, densidade de cargas líquidas carregadas pelo jato de solução e a tensão superficial. A tensão superficial caminha na direção da formação de beads, sendo que tensões superficiais reduzidas favorecem a formação de fibras sem beads (FONG; CHUN; RENEKER, 1999).

Conforme a viscosidade da solução aumenta, os beads se tornam maiores e a distância média entre eles também aumenta, as fibras ganham diâmetros mais largos e a forma dos beads se altera de esférica para fusiforme. Com o aumento da densidade de cargas líquidas, os beads se tornam menores e mais fusiformes, enquanto os diâmetros das fibras se tornam menores. A redução gradual da tensão superficial leva também ao desparecimento gradual dos beads. A neutralização das cargas carregadas pelo jato favorece a formação dos beads, desde que a tensão na fibra depende da repulsão das cargas líquidas e a interação das cargas líquidas com o campo elétrico (FONG; CHUN; RENEKER, 1999).

Não se é possível fazer recomendações gerais para concentrações particulares e viscosidades resultantes, condutividades elétricas e tensões superficiais, desde que os valores ideais destes parâmetros variam consideravelmente com o sistema polímero-solvente. Ainda que a técnica de eletrofiação de soluções poliméricas permita a produção de fibras com diâmetros relativamente pequenos, a sua produtividade, em termos de soluções que variam de $1-20 \%$ (massa), é moderado. Além disso, a rápida evaporação do solvente, no caso daqueles com baixo ponto de ebulição/alta pressão de vapor, pode impedir substancialmente - processo de eletrofiação e pode destruir a evolução das fibras pela geração de regiões filmogênicas (GREINER; WENDORFF, 2007). Uma alternativa poderia ser a eletrofiação a partir do estado fundido, mas para todos os casos, com poucas exceções (polímeros com pontos de fusão baixo), este método leva a diâmetros médios de fibra que são 
consideravelmente maiores que I $\mu \mathrm{m}$ e com ampla distribuição de diâmetros, como resultado de altas viscosidades dos polímeros (LYONS; LI; KO, 2004). Devido à alta viscosidade gerada pelo polímero fundido, a eletrofiação nestes casos exige grandes separações dos eletrodos, o que por sua vez exige maiores campos elétricos. Abaixo da atmosfera normal, campos elétricos muito elevados podem levar a risco de choque elétrico (FONG; CHUN; RENEKER, 1999).

\section{I.3.2 Eletrofiação aplicada à biomassa celulósica}

Fibras celulósicas comerciais têm sido constantemente fabricadas pelo processo de dry-jet wet spinning (fiação no estado úmido com jato seco) (TURBAK, I98I), com óxido de N-metilmorfolina (NMMO) / água (conhecido como processo Lyocel). Neste método, as fibras celulósicas são dissolvidas e então extrudadas em ar, sob calor e pressão adequadas, e então submergidas em um banho de coagulação. KANG et al. (2002) utilizou NMMO, pela primeira vez, para realizar a eletrofiação, juntamente com dióxido de nitrogênio. As fibras obtidas apresentaram diâmetros entre $200-400 \mathrm{~nm}$, e foram eletrofiadas, a $90-95{ }^{\circ} \mathrm{C}$, a partir de solução $2 \%$ de celulose mercerizada; entretanto, algumas fibras apresentaram diâmetros superiores a $700 \mathrm{~nm}$. Alguns anos depois, KIM et al. (2006) também eletrofiou celulose, entretanto, utilizou como solvente o sistema binário constituído de DMAc/LiCl com a solução à temperatura ambiente, mas com um coletor aquecido a $\sim 100^{\circ} \mathrm{C}$. O $\mathrm{LiCl}$, além da função no sistema de solvente sal/solvente orgânico, teve a função de ajudar a vencer as interações eletroestáticas entre a celulose e DMAc. Este estudo demonstrou que fibras secas e estáveis poderiam ser fiadas a partir de soluções de celulose $3 \%$ em DMAc/LiCl, usando um banho de coagulação (para remoção de $\mathrm{LiCl}$ ) e coletores aquecidos (para remoção de solvente).

Uma das grandes vantagens no uso de $\mathrm{DMAc} / \mathrm{LiCl}$ está no fato que este sistema de solvente dissolve celuloses de diferentes origens, a várias concentrações, e trata-se de um sistema de solvente não derivatizante. Já o uso de $\mathrm{NMMO} / \mathrm{H}_{2} \mathrm{O}$ requer elevadas temperaturas para eletrofiação (soluções aquecidas) (KIM et al., 2006) e apresenta uma gama limitada de aplicação no campo da fiação, apesar deste consistir em um sistema mais simples 
que DMAc/LiCl. Destaca-se que as fibras produzidas a partir de processos diferentes, como celuloses eletrofiadas em sistemas de solventes diferentes (DMAc/LiCl e $\mathrm{NMMO} / \mathrm{H}_{2} \mathrm{O}$ ) podem diferir estruturalmente. KIM et al. (2006) demonstrou que fibras a partir de $\mathrm{DMAc/LiCl}$ mostravam ser não cristalinas, enquanto as fibras a partir do outro sistema de solvente apresentava cristalinidade.

O derivado de celulose provavelmente mais conhecido, o acetato de celulose, tem sido eletrofiado faz algum tempo (Tabela 20). Em I998, JAEGER et al. (1998), a partir de uma solução de acetato de celulose em acetona, obteve fibras com beads. Estes "defeitos" ao longo da fibra podem ser oriundos da baixa viscosidade do solvente e, devido ao baixo ponto de ebulição da acetona, pode ocorrer também a rápida evaporação do solvente e gelificação da solução, o que afeta a formação contínua de fibras, levando à ocorrência de defeitos (BARTHEL; HEINZE, 2006).

Tabela 20 - Exemplos de soluções de celulose e derivados de celulose usados na técnica de eletrofiação.

\begin{tabular}{|c|c|c|}
\hline Polímero & Solvente(s) & Referências \\
\hline \multirow{5}{*}{ Celulose } & NMMO & (KANG et al., 2002) \\
\hline & $\mathrm{NMMO} / \mathrm{H}_{2} \mathrm{O}(\mathrm{I}: \mathrm{I})$ & (KIM et al., 2006) \\
\hline & NMMO/DMSO & (MAGALHÃES; CAO; LUCIA, 2009) \\
\hline & 8 wt\% DMAc/LiCl & (KIM et al., 2006) \\
\hline & Líquidos lônicos & (HÄRDELIN et al., 20I2) \\
\hline \multirow[t]{2}{*}{ Acetato de celulose } & Acetona & $(\mathrm{HUI}, 20 \mathrm{II})$ \\
\hline & Acetona/DMAc (1:2 / 2:1) & (LI; XIA, 2004) \\
\hline Etilcelulose & THF/DMAc (100:0 / I:4) & (PARK; HAN; LEE, 2007) \\
\hline \multirow[t]{2}{*}{ Metilcelulose } & $\mathrm{H}_{2} \mathrm{O} /$ Etanol $(\mathrm{I}: \mathrm{I})$ & (FRENOT; HENRIKSSON; \\
\hline & & WALKENSTRÖM, 2007) \\
\hline
\end{tabular}

Embora, nas últimas décadas, a técnica de eletrofiação tenha ganhado destaque como uma técnica versátil na preparação de fibras nas escalas submicrométrica e nano, tem havido uma notável falta de investigação considerando como matéria-prima a biomassa lignocelulósica, ou seja, fibras constituídas majoritariamente por celulose, hemiceluloses e lignina. Poucos estudos têm sido publicados a respeito da eletrofiação da biomassa lignocelulósica, e todos eles são restritos ao uso da biomassa pré-tratada com solução aquosa alcalina, ao líquido iônico acetato de I-etil-3-metilimidazol como solvente e DMF 
com co-solvente para aumentar a fiabilidade (AHN et al., 20I2; KANG et al., 20I3). Nestes estudos anteriores, os autores empregaram o tratamento alcalino visando reduzir a quantidade de lignina e hemiceluloses na fibra lignocelulósica, visando aumentar o teor de celulose, em busca de favorecimento na posterior eletrofiação. Entretanto, até o presente trabalho, a eletrofiação em temperatura ambiente da biomassa lignocelulósica sem prévio pré-tratamento, não havia sido reportada.

$\mathrm{Na}$ eletrofiação à temperatura ambiente, o uso de um solvente que volatilize facilmente nesta condição é altamente desejado. Neste contexto, o ácido trifluoroacético (TFA), um ácido organofluorado, é amplamente usado em síntese orgânica devido a sua elevada força ácida, alta volatilidade e miscibilidade com uma vasta gama de solventes orgânicos. Ao longo dos anos, TFA tem sido usado para romper a rede cristalina da celulose, levando a completa separação e dissolução de suas cadeias devido à esterificação quase que exclusiva dos grupos hidroxila no carbono C6 (HASEGAWA et al., 1992).

O alto conteúdo de celulose na fibra lignocelulósica de sisal, com o único componente fiável, favorece a fiação das hemiceluloses e particularmente da lignina, quando estes três componentes são eletrofiados. A estrutura linear da celulose favorece o alinhamento de suas cadeias, o que não é favorecido no caso das hemiceluloses e inviável no caso da lignina. A lignina, como já abordado anteriormente (Revisão Bibliográfica, Seção I.2.3), consiste de uma rede macromolecular tridimensional (protolignina) e por isso a sua dissolução requer a quebra de ligações covalentes para romper essa rede 3D. FANTA et al. (1984) investigaram a hidrólise da palha de trigo com TFA IN por $7 \mathrm{~h}$ e reportaram a degradação da hemicelulose e lignina em $80 \%$ e 10\%, respectivamente, enquanto as macromoléculas de celulose permaneceram não afetadas após a dissolução em TFA. Mais tarde, MORRISON; STEWART (1998) e DONG et al. (2009) também reportaram não haver significativa despolimerização da celulose após 8 dias de solubilização em TFA (99\%) a $37^{\circ} \mathrm{C}$ ou 16 h de solubilização em TFA (>99\%) a $60^{\circ} \mathrm{C}$, respectivamente.

Neste trabalho, uma nova abordagem envolvendo a eletrofiação, a temperatura ambiente, da biomassa lignocelulósica não previamente tratada (fibra lignocelulósica de sisal) e o seu componente principal (celulose de sisal) foi explorada. TFA foi usado como solvente para "separar" os componentes da fibra lignocelulósica, consequentemente levando à dissolução da celulose, hemiceluloses e lignina. A posterior reconstrução da fibra na escala nanométrica ou submicrométrica (ultrafinas) foi realizada via eletrofiação, a temperatura 
ambiente. Para se avaliar a influência da lignina e hemiceluloses durante 0 processo de eletrofiação, a celulose de sisal mercerizada, a qual é livre de lignina e possui um baixo conteúdo de hemiceluloses, foi também considerada no processo de eletrofiação. Levandose em conta que as hemiceluloses e lignina são fortemente ligadas à celulose na estrutura fibrosa lignocelulósica, estes componentes dificultam os movimentos das cadeias de celulose em solução, o que pode influenciar no jato e na fiação da celulose.

Até onde chega o nosso conhecimento, esta foi a primeira vez em que fibras ultrafinas foram produzidas a partir da biomassa lignocelulósica por eletrofiação a temperatura ambiente, utilizando-se TFA como solvente. O processo descrito neste trabalho traz vantagens tecnológicas associadas à economia energética de usar a fibra lignocelulósica nativa, sem a necessidade de pré-tratamentos e também representa reduções de custos associadas ao uso de apenas um solvente. Estas fibras ultrafinas podem ser usadas em uma vasta gama de aplicações, por exemplo, como membranas para preparar estruturas filmogênicas em "sanduíche" ou até mesmo como reforço em compósitos, em vista que os micro/nanodiâmetros resultam em uma alta área de superfície especifica, de até 1000 vezes maior que para microfibras, o que permite um contato direto entra as cadeias celulósicas e as matrizes poliméricas. 


\section{Experimental}

\section{I Materiais}

Como materiais de partida, utilizou-se a celulose de sisal mercerizada (será adotada a sigla SP, no presente capítulo) e a fibra lignocelulósica de sisal (será adotada a sigla LSF, no presente capítulo), a qual foi adquirida da Sisal Sul Indústria e Comércio LTDA, São Paulo, Brasil. As fibras lignocelulósicas de sisal foram refluxadas em um sistema etanol/cicloexano $(I: I, v / v, 10 \mathrm{~min})$ visando a remoção de terpenos, gorduras e ceras. Ressalta-se que este processo não tem influência e/ou altera o teor de celulose, hemiceluloses e lignina. A composição das fibras foi previamente determinada por DE OLIVEIRA SANTOS et al. (20I4) como sendo: $64,9 \pm 2,7 \%$ celulose; II,7 $\pm 0,9 \%$ lignina; $25,4 \pm 4,3 \%$ hemiceluloses; $7,1 \pm 0,1 \%$ umidade; $0,4 \pm 0,1 \%$ cinzas. $O$ índice de cristalinidade, determinado via difração de raios $X$ foi de $58 \%$ (DE OLIVEIRA SANTOS et al., 20I4).

Como solvente, utilizou-se o ácido trifluoroacético (TFA) (Mallinckrodt Chemicals), da forma como foi recebido.

\subsection{Dissolução dos materiais de partida}

LSF e SP foram solubilizadas em TFA em concentrações de $2 \times 10^{-2} \mathrm{~g} \mathrm{~mL}^{-1}$ e $3 \times 10^{-2} \mathrm{~g}$ $\mathrm{mL}^{-1}$, respectivamente, sob agitação magnética, a temperatura ambiente. Após $48 \mathrm{~h}$ de agitação, constatou-se a completa solubilização dos materiais de partida e soluções monofásicas e homogêneas foram obtidas.

Ressalta-se que, para ambos os materiais de partida, concentrações superiores às utilizadas foram testadas, o que levou à gelificação das soluções após dissolução, inviabilizando o processo de eletrofiação. Concentrações inferiores às utilizadas levaram a 
não eletrofiação ou a um fenômeno semelhante ao electrospraying (dispersão da solução em forma de aerossol), no caso de LSF e SP, respectivamente.

\subsection{Processo de Eletrofiação}

Para a eletrofiação, utilizou-se um aparato de eletrofiação da IME Technologies (Figura 76). As soluções foram acondicionadas em tubos capilares (diâmetro interior: I,00 mm; diâmetro exterior: I,6 mm), os quais foram conectados a uma bomba para o controle da vazão de solução. A voltagem utilizada foi de $25 \mathrm{kV}$ e a distância agulha-coletor de $4 \mathrm{~cm}$.

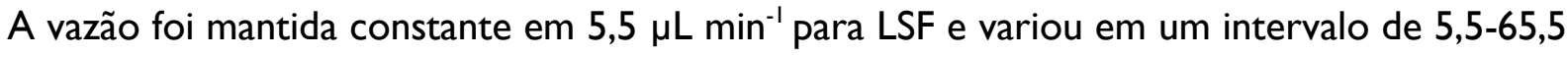
$\mu \mathrm{L} \min ^{-1}$ para SP. Em todos os casos, foram usadas agulhas com diâmetro interno de 0,45 $\mathrm{mm}$ e, como aparato coletor de fibras, utilizou-se chapas delgadas de vidro acopladas ao contra eletrodo (coletor metálico).

\subsection{Caracterização dos materiais}

\subsection{FTIR-ATR}

As análises de FTIR-ATR foram realizadas no Grupo de Fotoquímica do Instituto de Química de São Carlos, USP. Para as análises, utilizou-se um espectrômetro da Perkin-Elmer modelo 100 FTIR com um acessório de amostragem ATR (Attenuated total reflectance) acoplado (Perkin-Elmer Inc., Norwalk, CT, USA). Antes de cada análise, as amostras foram secas a $105^{\circ} \mathrm{C}$ por $4 \mathrm{~h}$. Os espectros foram coletados a temperatura ambiente na região de $4000-600 \mathrm{~cm}^{-1}$. 


\subsubsection{Microscopia Eletrônica de Varredura}

As análises das nanofibras obtidas foram realizadas segundo procedimento descrito no Capítulo I item 2.2.7, contando também com a obtenção de imagens a partir do uso de outro Microscópio Eletrônica de Varredura, FEl Magellan 400 L, do Laboratório de Caracterização Estrutura/DEMA (Departamento de Engenharia de Materiais), da Universidade Federal de São Carlos (UFSCar).

\subsubsection{Análise Termogravimétrica}

Procedimento idêntico ao descrito no Capítulo I, Seção 2.2.8. 
P ág i n a | 222 


\section{Resultados e discussão}

\section{I FTIR-ATR}

A Figura 79 mostra os espectros de FTIR obtidos para a LSF de partida e eletrofiada.

Figura 79 - Espectros de FTIR-ATR para a LSF de partida e eletrofiada (a) e ampliação na região de $2200-600 \mathrm{~cm}^{-1}$ (b).
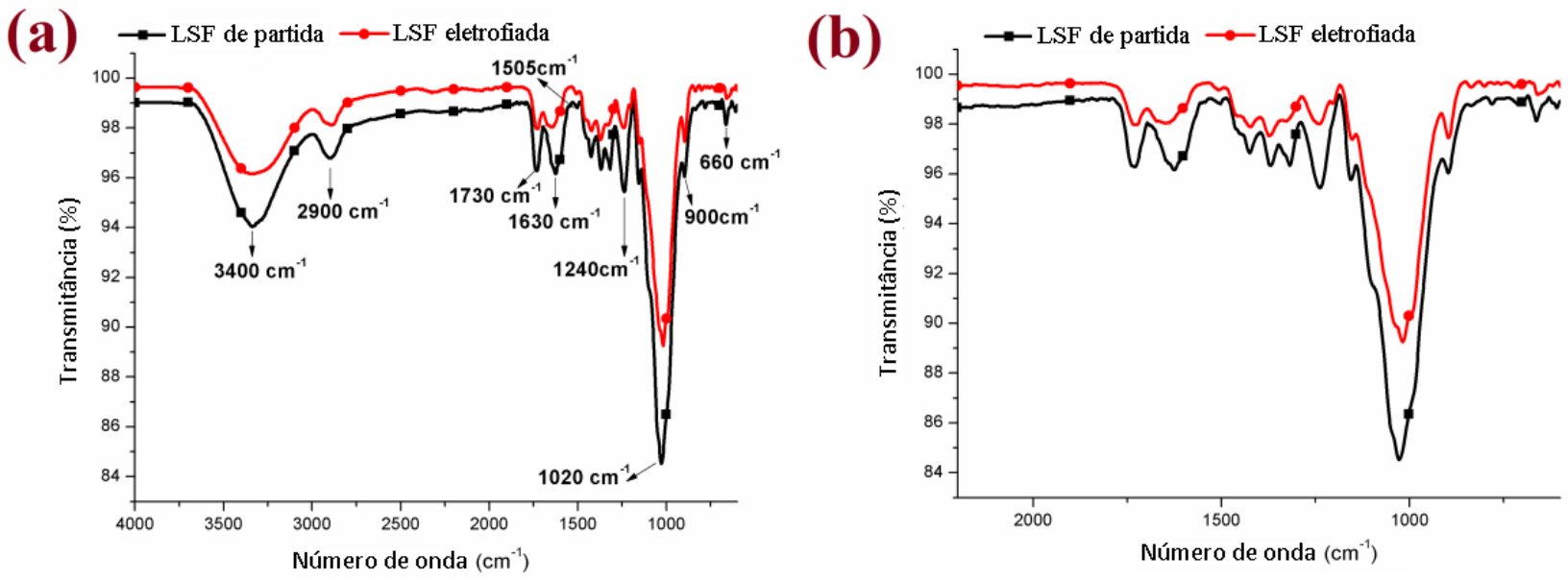

Os espectros de FTIR para LSF de partida e eletrofiada (Figura 79) revelaram picos/bandas característicos de um típico material lignocelulósico. Em aproximadamente $3400 \mathrm{~cm}^{-1}$, observou-se uma banda intensa, a qual pode ser atribuída ao estiramento da ligação O-H das hidroxilas presentes na celulose, lignina e hemiceluloses; bandas adicionais envolvendo a deformação da ligação $\mathrm{O}-\mathrm{H}$, de água residual adsorvida, também foram observadas em $1630 \mathrm{~cm}^{-1}$; estiramento da ligação C-H em $2900 \mathrm{~cm}^{-1}$; vibrações de estiramento da ligação C-O do esqueleto da celulose em $1020 \mathrm{~cm}^{-1}$; modos de deformação das ligações C-O-C, C-C-O e C-C-H e vibrações de estiramento dos átomos de C-5 e C-6 em $900 \mathrm{~cm}^{-1}$ (PRONIEWICZ et al., 200I); deformação fora do plano da ligação C-OH em $668 \mathrm{~cm}^{-1}$ (SCHWANNINGER et al., 2004); vibrações do esqueleto aromático da lignina em $1505 \mathrm{~cm}^{-1}$; deformação axial assimétrica da ligação =C-O-C da lignina em $1240 \mathrm{~cm}^{-1}$, vibração 
de valência da ligação $\mathrm{C}=\mathrm{O}$ dos grupos acetil e $\mathrm{COOH}$ nas xilanas das hemiceluloses em $1730 \mathrm{~cm}^{-1}$.

Os grupos hidroxilas da celulose, hemiceluloses e lignina podem ser esterificados por ação do solvente (Figura 80), TFA, o qual também pode agir como um catalisador ácido neste tipo de reação. Neste caso, seriam esperados que picos na região de $1790 \mathrm{~cm}^{-1}$, nos espectros de FTIR, fossem obtidos, os quais seriam relacionados à absorção dos carbonilas dos grupos trifluoroacetato.

Figura 80 - Principais componentes de uma fibra lignocelulósica: sítios reativos suscetíveis à esterificação pelo TFA.
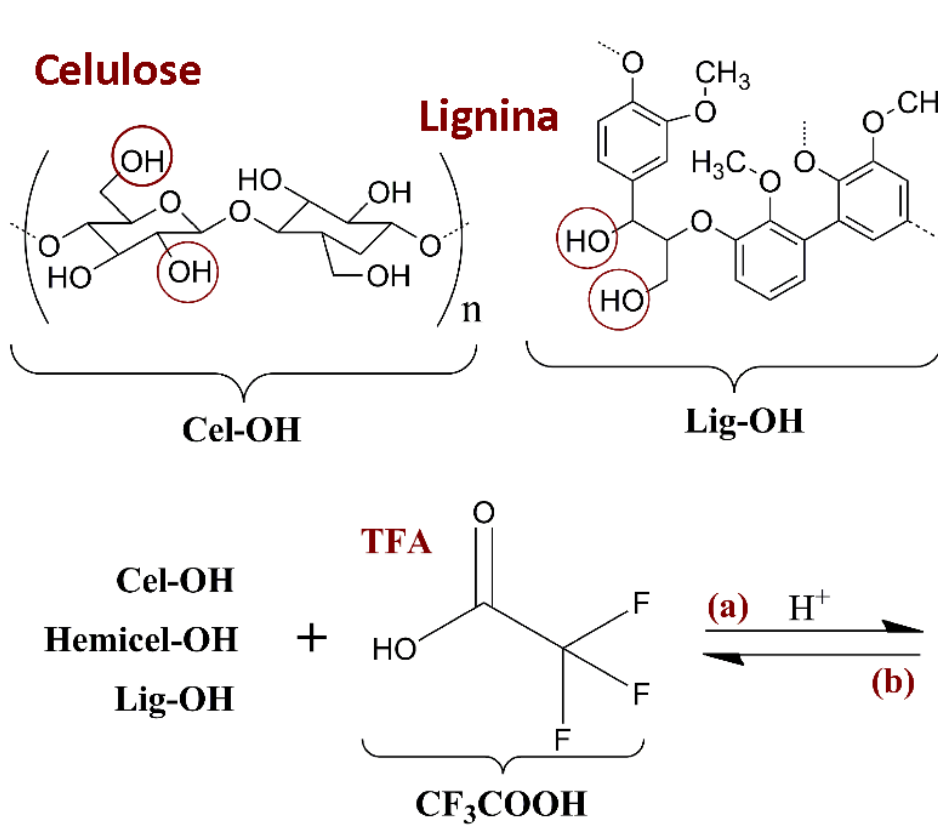

(a)reação de esterificação

(b) reação de hidrólise

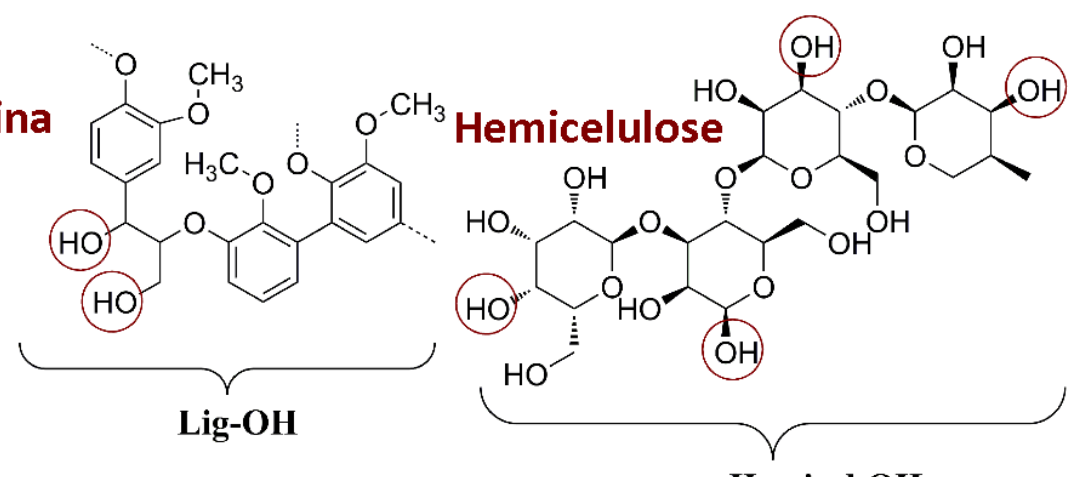

Hemicel-OH

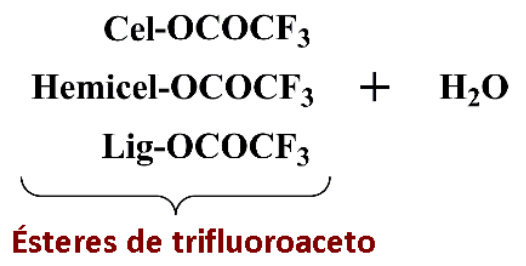

HASEGAWA et al. (1992) demonstraram que as moléculas de celulose são dissolvidas em TFA por meio da formação de grupos ésteres do tipo trifluoracetil, quase que seletivamente localizados nos grupos hidroxilas primários do carbono $\mathrm{C} 6$, da cadeia de celulose. MONTAÑO-LEYVA et al. (20II) reportaram que nanofibras de celulose obtidas por eletrofiação, a partir do uso de TFA como solvente, possuíam uma banda em $1790 \mathrm{~cm}^{-1}$ nos espectros de FTIR, devido às carbonilas dos grupos trifluoracetilas. Entretanto, nesse mesmo estudo, o autor relatou que com o passar do tempo e a constante exposição das nanofibras ao ar (presença de umidade), a banda referente às carbonilas dos grupos trifluoracetato desapareceu, devido à hidrólise deste grupo éster, que regenera os grupos 
hidroxila. No caso dos componentes da fibra lignocelulósica, isto significa regenerar celulose, hemiceluloses e lignina (Figura 80, (b) reação de hidrólise).

As análises de espectroscopia na região do infravermelho das fibras obtidas no presente trabalho, via eletrofiação, a partir de fibras de sisal, não foram feitas de imediato após a eletrofiação. Os espectros obtidos indicaram que se ocorreu a esterificação durante a dissolução, os grupos ésteres foram hidrólisados em contato com a umidade do ar. Este fato é suportado pelo fato de não haver nenhuma banda na região de $1790 \mathrm{~cm}^{-1}$ no espectro de FTIR de LSF eletrofiada (Figura 79).

A Figura 81 mostra os espectros de FTIR para SP de partida e eletrofiada.

Figura 8I - Espectros de FTIR-ATR para SP de partida e eletrofiada (a) e ampliação na região de $2200-600 \mathrm{~cm}^{-1}$ (b).
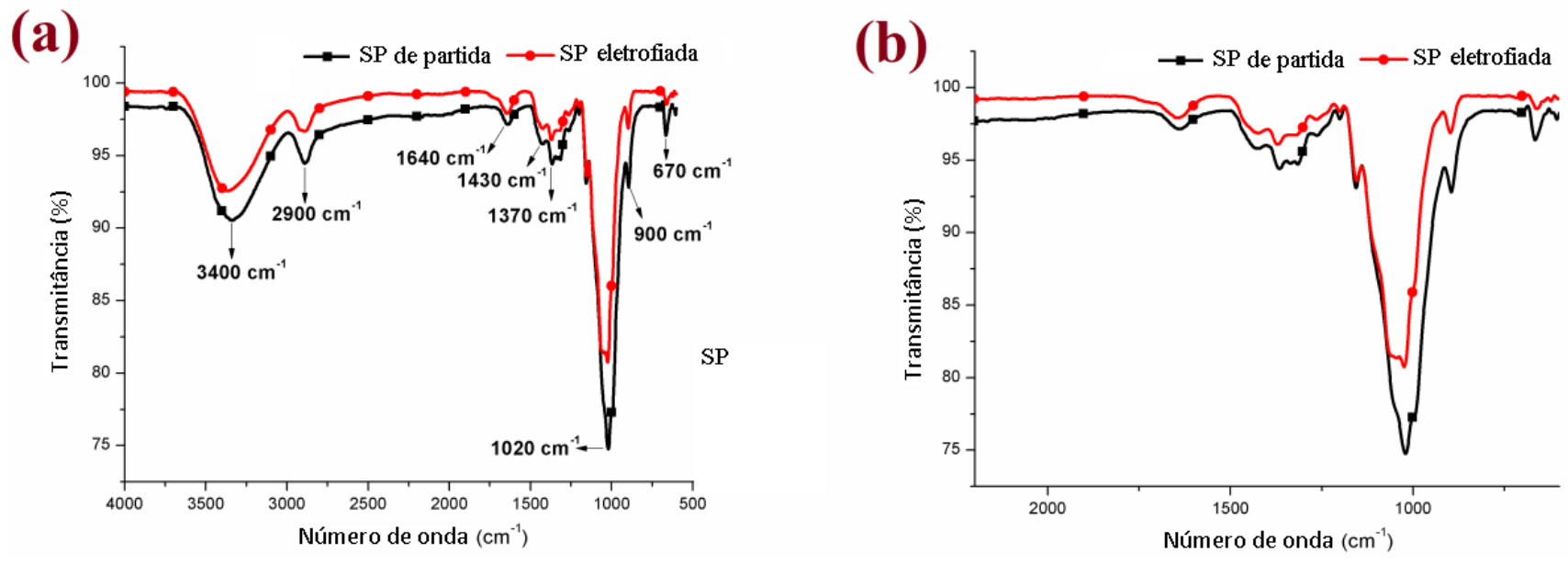

Os espectros para SP de partida e eletrofiada (Figura 8I) revelaram picos/bandas característicos de um típico material celulósico. Em aproximadamente $3400 \mathrm{~cm}^{-1}$, observouse uma banda intensa, a qual pode ser atribuída ao estiramento da ligação $\mathrm{O}-\mathrm{H}$ das hidroxilas celulósicas; estiramento da ligação C-H em $2900 \mathrm{~cm}^{-1}$; vibrações de deformação no plano das ligações $\mathrm{H}-\mathrm{C}-\mathrm{H}$ e O-C-H em $1430 \mathrm{~cm}^{-1}$; vibração de deformação da ligação C-H em 1370 $\mathrm{cm}^{-1}$; vibrações de estiramento da ligação C-O do esqueleto da celulose em $1020 \mathrm{~cm}^{-1}$; modos de deformação das ligações C-O-C, C-C-O e C-C-H e vibrações de estiramento dos átomos de C-5 e C-6 em $900 \mathrm{~cm}^{-1}$ (PRONIEWICZ et al., 200I); deformação fora do plano da ligação C-OH em $668 \mathrm{~cm}^{-1}$ (SCHWANNINGER et al., 2004). Bandas adicionais, 
envolvendo a deformação da ligação O-H de água adsorvida, também foram observadas em $1640 \mathrm{~cm}^{-1}$.

Os espectros de FTIR para SP de partida e eletrofiada (Figura 8I) não mostraram diferenças significativas e nenhuma banda na região de $1790 \mathrm{~cm}^{-1}$ foi observado, o que é novamente um indicativo da ausência de grupos trifluoroacetato após eletrofiação e exposição ao ambiente.

\subsection{Microscopia Eletrônica de Varredura (MEV)}

A Figura 82 mostra as micrografias para a amostra de LSF eletrofiada. 
Figura 82 - Micrografias das fibras obtidas a partir da eletrofiação da LSF em TFA.

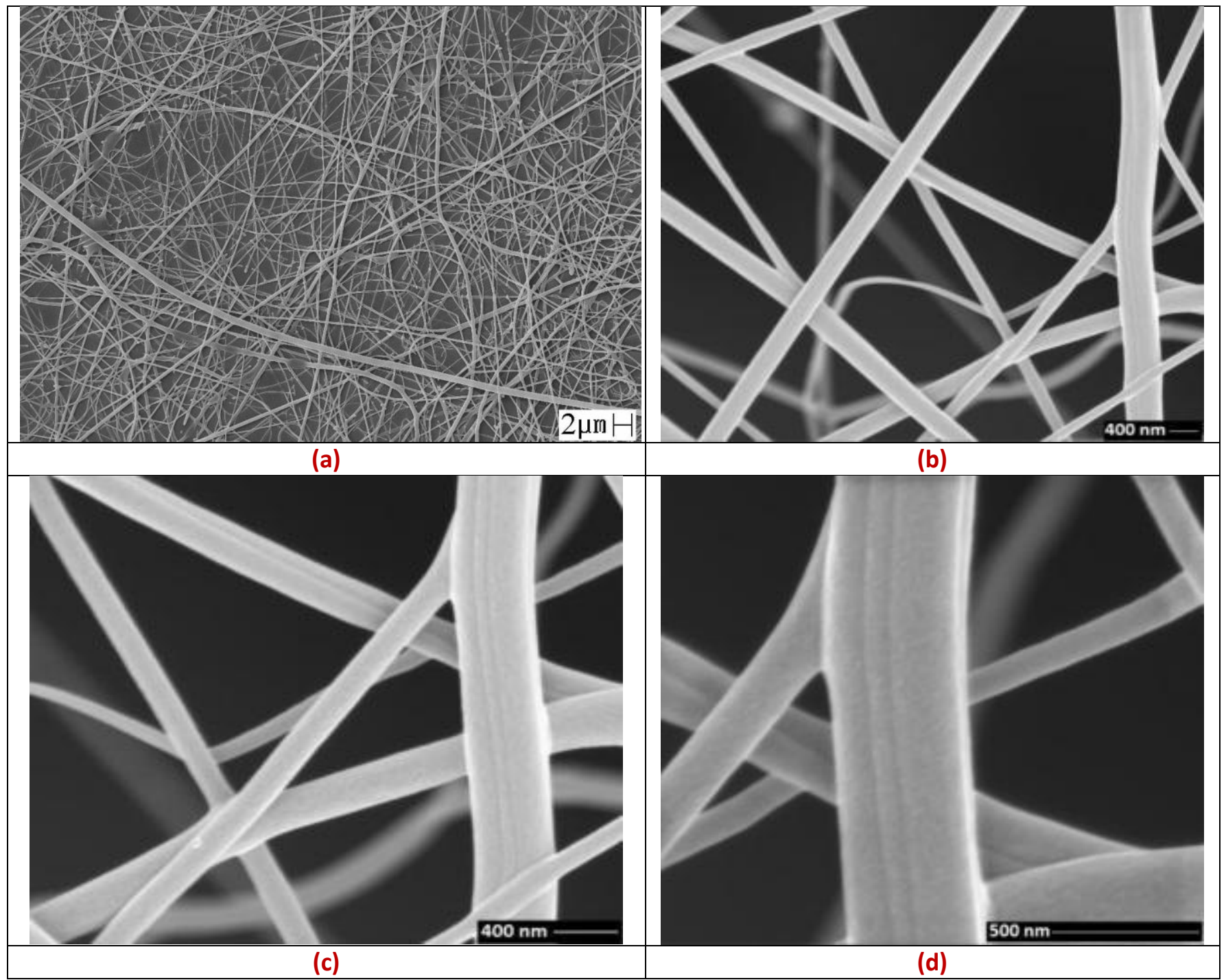

As micrografias para a amostra de LSF eletrofiada (Figura 82) mostraram uma rede homogênea de fibras ultrafinas, as quais apresentaram um largo intervalo de diâmetro (I20$510 \mathrm{~nm}$ ), com um diâmetro médio de $230 \mathrm{~nm}$. Esse largo intervalo pode ser atribuído à presença de lignina na fibra lignocelulósica, a qual pode interferir na fiação da celulose por perturbar o alinhamento das cadeias poliméricas, levando a produção de fibras eletrofiadas com amplos intervalos de diâmetros.

Diferentemente dos trabalhos reportados por AHN et al. (2012) e KANG et al. (20/3), nos quais a biomassa lignocelulósica previamente tratada com solução aquosa alcalina foi eletrofiada a partir de soluções em líquidos iônicos/DMF, as fibras eletrofiadas obtidas neste trabalho exibiram uma rede homogênea, com superfícies lisas e sem defeitos, tais como fibras “dobradas", nós e regiões filmogênicas. No estudo publicado por AHN et al. 
(20/2), para se alcançar uma eletrofiação estável, fibras lignocelulósicas (cânhamo) precisaram de um pré-tratamento em $\mathrm{NaOH}$ 17,5\% (I h, temperatura ambiente) seguido de tratamento em $\mathrm{NaClO}_{2}(5 \mathrm{~h}$, ebulição) para gerar uma redução do teor de lignina de 7,I para 4,2\%; outros pré-tratamentos realizados neste estudo levaram a fibras com um teor de lignina $>5 \%$, as quais não foram eletrofiadas com sucesso, seja pela ocorrência de electrospraying, seja pela eletrofiação com a presença de defeitos como nós, fibras “dobradas” e regiões filmogênicas. Nos pré-tratamentos em solução alcalina aquosa, reportados por AHN et al. (20I2), reportou-se também que a celulose, após o tratamento alcalino, foi também parcialmente degradada. Ressalta-se que as fibras lignocelulósicas de sisal, utilizadas no presente trabalho, possuíam um teor de lignina de $1 \mathrm{I}, 7 \%$. Este teor de lignina é cerca de $65 \%$ maior que o teor para as fibras de cânhamo nativa reportadas por AHN et al. (20/2) e $280 \%$ maior que as fibras de cânhamo tratadas em meio aquoso alcalino (4,2\% de lignina após tratamento), as quais foram as únicas que se mostraram adequadas para dissolução e posterior eletrofiação.

Assim, o presente trabalho representa um grande avanço ao eletrofiar fibras lignocelulósicas, sem a necessidade de tratamento prévio, e com maiores teores de lignina, o que, no geral, pode contribuir negativamente na fiabilidade das soluções.

A Figura 83 mostra as micrografias para a membrana obtida pela eletrofiação da solução da polpa celulósica de sisal (SP). 
Figura 83 - Micrografias das fibras obtidas a partir da eletrofiação de SP, em TFA, em diferentes vazões de solvente.

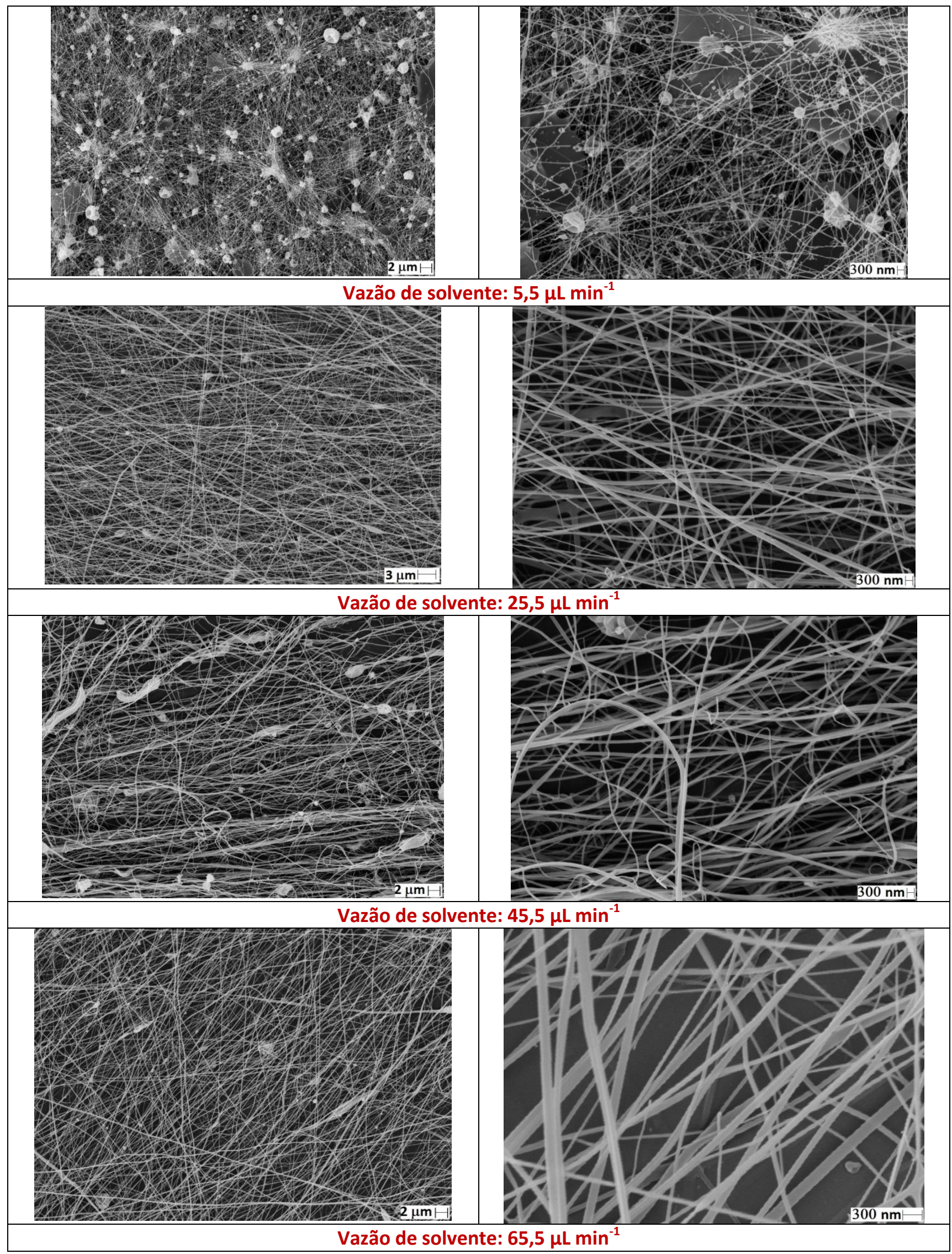


As micrografias para a SP eletrofiada (Figura 83) indicaram que, com o aumento do fluxo da solução, usando-se fluxos de solução de $25,5,45,5$ e $65,5 \mu \mathrm{L} \min ^{\top} \mathrm{I}$, houve o decréscimo da presença de defeitos ao longo das redes de fibras. Assim, nanofibras $(<100$ $\mathrm{nm}$ ) e fibras ultrafinas foram produzidas com diâmetros no intervalo de 65-160 nm, 90-165 $\mathrm{nm}$ e 90-200 nm, no sentido crescente de fluxo de solução. Estes resultados demonstram que o aumento no fluxo de solvente levou a um aumento nos diâmetros médios das fibras obtidas. LIM et al. (2010) também constataram, ao eletrofiar etilcelulose em trifluoretanol, que o aumento do fluxo de solvente levou a formação de fibras com diâmetros médios superiores. Son et al. (2004) também observaram um aumento linear nos diâmetros médios das fibras com o aumento do fluxo de solvente, na eletrofiação de acetato de celulose em acetona/água. Estudos anteriores, os quais também usaram TFA como solvente na dissolução da massa celulósica, reportaram nanofibras de algodão e polpa de madeira no intervalo de 30-50 nm (OHKAWA et al., 2009) e fibras ultrafinas a partir de palha de trigo Durum com diâmetros na ordem de 270 nm (MONTAÑO-LEYVA et al., 20I I).

O diâmetro da fibra eletrofiada e do jato da solução, durante o processo de eletrofiação, possuem estrita correlação com a taxa de vazão da solução (MUNIR et al., 2009). De acordo com observações empíricas, um aumento na vazão produz fibras mais com diâmetros maiores (SON et al., 2004b; HOMAYONI; RAVANDI; VALIZADEH, 2009), enquanto for possível manter o cone de Taylor estável (SON et al., 2004b). Entretanto, se a vazão é muito alta para permitir o tempo necessário para evaporação do solvente da fibra, uma rede "achatada" de fibras pode ser obtida. Portanto, uma taxa de vazão baixa é tipicamente visada enquanto se é possível manter o cone de Taylor, desde que há tempo suficiente para a evaporação do solvente e resulta em fibras mais finas e homogêneas. No entanto, para SP, a menor taxa de vazão $\left(5,5 \mu \mathrm{L} \mathrm{min}{ }^{-1}\right)$ resultou em uma rede de fibras com a presença de beads e algumas regiões "achatadas". Provavelmente, esse fluxo de solvente estava abaixo do limiar para a voltagem de operação $(25 \mathrm{kV})$, o que pode ter levado à evaporação do solvente na agulha, o que causou instabilidade do jato durante a eletrofiação. Assim, esse fluxo levou as fibras mais finas de todas $(40-60 \mathrm{~nm})$, embora tenha resultado em uma rede de fibras defeituosas.

FONG; CHUN; RENEKER (1999) propuseram que a formação das fibras, durante a eletrofiação, é dependente de uma combinação de fatores: balanço de forças causadas pela tensão superficial, viscosidade da solução e densidade de cargas líquidas no jato. Ressalta-se 
que diferentes concentrações de LSF e SP foram testadas para se determinar as condições ótimas (por exemplo, viscosidade) que levassem à eletrofiação de cada um destes materiais. A alta viscosidade da solução de LSF $\left(2 \times 10^{-2} \mathrm{~g} \mathrm{~mL}^{-1}\right)$, a qual foi devida à presença de lignina (II,7\%) e hemiceluloses (25,4\%), mostrou-se adequada para ○ processo de eletrofiação. Novamente, destaca-se que essa concentração de LSF foi o limiar para prevenir a gelificação da solução e, abaixo desse limiar, a eletrofiação não foi possível sob as condições testadas. Por outro lado, para SP, o qual é livre de lignina e possui um baixo teor de hemiceluloses (Capítulo I, Seção 3.I.5), exibiu menor viscosidade que a solução de LSF na mesma concentração de $2 \times 10-2 \mathrm{~g} \mathrm{~mL}^{-1}$ (não adequada para eletrofiação sob as condições testadas), a qual precisou ser aumentada (para $3 \times 10-2 \mathrm{~g} \mathrm{~mL}^{-1}$ ) para permitir a eletrofiação. Devido a estas diferenças, a vazão de solução também requisitou ajustes para otimizar o processo de eletrofiação para cada solução (LSF e SP). Portanto, somente a menor vazão entre as testadas, de 5,5 $\mu \mathrm{L} \mathrm{min}^{-1}$, resultou na eletrofiação da solução de LSF, enquanto aumentos nesta levaram ao fenômeno de electrospraying.

\subsection{Análise Termogravimétrica}

A Figura 84 apresenta as curvas dTG para a SP e LSF de partidas e eletrofiadas. 
Figura 84 - Curvas dTG da (a) LSF de partida e eletrofiada e (b) da SP de partida e eletrofiada (atmosfera de $\mathrm{N}_{2}$, taxa de aquecimento de $20^{\circ} \mathrm{C} \mathrm{min}^{-1}$ ).

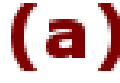

$\rightarrow$ LSF de partida - - LSF eletrofiada

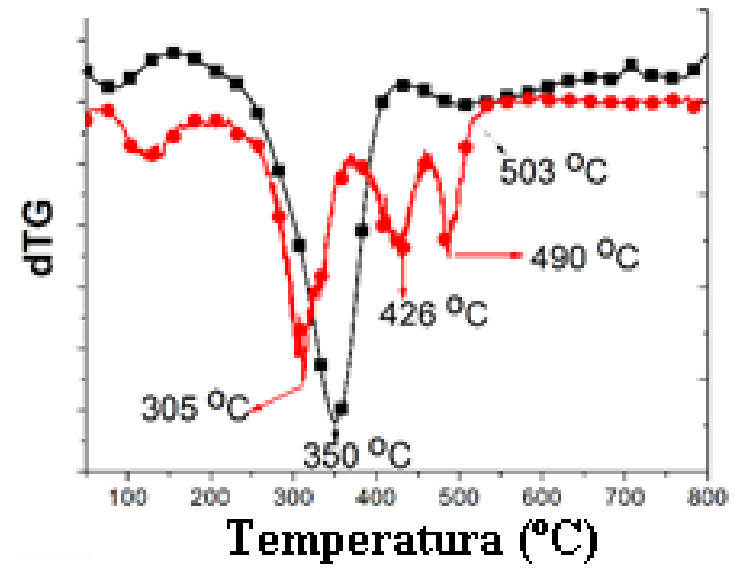

(b)

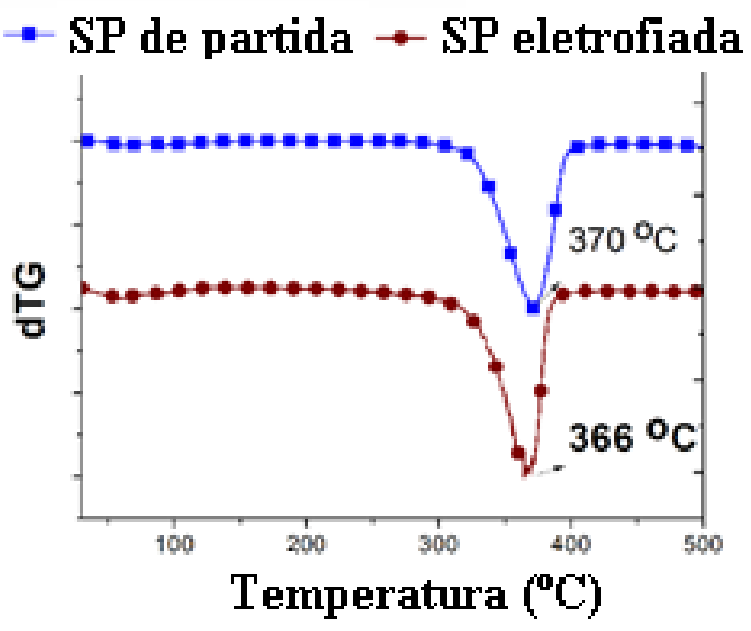

Na região de $75-125^{\circ} \mathrm{C}$, as curvas dTG da LSF de partida e eletrofiada [Figura 84-(a)] exibiram um pico, o qual foi provavelmente associado à perda de água devido à umidade absorvida e adsorvida pela fibra (ORNAGHI et al., 20l4) [perda de massa de aproximadamente $6 \%$, baseado na curvas TGs (figuras não mostradas)]. A maior parte das moléculas de água é ligada às cadeias de hemiceluloses presentes nas regiões não cristalinas da fibra. Nos intervalos de $245-380^{\circ} \mathrm{C}$ (LSF eletrofiada) e $245-450{ }^{\circ} \mathrm{C}$ (LSF de partida), as curvas TG (figuras não mostradas) mostraram uma perda de massa de $52 \%$ e $46 \%$, respectivamente, e picos de $\mathrm{T}_{\mathrm{p}}$ de $305{ }^{\circ} \mathrm{C}$ e $350{ }^{\circ} \mathrm{C}$ [curvas dTG, Figura 84-(a)], respectivamente, os quais podem ser atribuídos à decomposição da hemicelulose seguido da decomposição da celulose. Os valores de $T_{p}$, os quais correspondem à taxa máxima de perda de massa, indicam que a LSF eletrofiada exibiu uma menor estabilidade térmica que a LSF de partida.

O pico largo e de baixa intensidade observado na curva dTG da LSF de partida [Figura 84-(a)], em cerca de $503^{\circ} \mathrm{C}$, relaciona-se à quebra de ligações da protolignina (lignina nativa). A estrutura aromática da lignina confere uma maior estabilidade térmica a essa macromolécula comparativamente à celulose. Em comparação à LSF de partida, a curva TG da LSF eletrofiada (figura não mostrada) exibiu um perfil diferente a partir de $400{ }^{\circ} \mathrm{C}$, e dois picos foram observados em $426^{\circ} \mathrm{C}$ e $490^{\circ} \mathrm{C}$ (dTG). Ambos os picos podem ser atribuídos à decomposição térmica das estruturas geradas pela quebra da protolignina durante a dissolução em TFA. Como abordado anteriormente, a dissolução da fibra lignocelulósica 
requer que ligações covalentes sejam quebradas visando romper a rede $3 D$ da lignina, o que leva à degradação da protolignina. Portanto, a decomposição térmica das estruturas geradas pela quebra da protolignina foi provavelmente responsável pelos diferentes comportamentos/perfis observados nas curvas TG e dTG e pela diferença de estabilidade térmica observada.

Curvas TG (figuras não mostradas) e dTG [Figura 84-(b)] similares foram obtidas para a SP de partida e eletrofiada. Até $125^{\circ} \mathrm{C}$, uma perda de massa de aproximadamente $6 \%$ foi observada devido à água absorvida/adsorvida. Nos intervalos de $260-420{ }^{\circ} \mathrm{C}$ e $240-415$ ${ }^{\circ} \mathrm{C}$, a SP de partida e eletrofiada passaram por uma perda de massa de $77 \%$ e $80 \%$, respectivamente, as quais foram devido à despolimerização da celulose. De acordo com as curvas dTG [Figure 84-(b)], os valores de $T_{p}$ para SP eletrofiada e de partida foram próximos, nos valores de $366^{\circ} \mathrm{C}$ e $370^{\circ} \mathrm{C}$, respectivamente.

\section{Breve Sumário e Conclusões Parciais}

O estudo aqui apresentado introduziu um novo método para a eletrofiação da biomassa lignocelulósica, à temperatura ambiente, a partir de fibras lignocelulósicas de sisal como material de partida. $O$ ácido trifluoroacético demonstrou ser um excelente solvente para romper a estrutura fibrosa lignocelulósica, o que levou à separação de seus principais componentes. A partir do uso da técnica de eletrofiação, a reconstrução da estrutura fibrosa lignocelulósica (LSF) gerou redes homogêneas de fibras ultrafinas com diâmetros variando no intervalo de 120 a $510 \mathrm{~nm}$, sem a presença de resíduos não-eletrofiados. A eletrofiação do principal componente da fibra lignocelulósica, a celulose (SP), pode também ser realizada à temperatura ambiente, e além de fibras ultrafinas, nanofibras foram geradas. Neste caso, alguns ajustes na vazão da solução foram necessários para a obtenção de redes de fibras mais homogêneas e livres de defeitos. Assim, fibras ultrafinas e nanofibras de celulose foram geradas em uma ampla janela de diâmetros apenas variando a vazão da solução. Os resultados apresentados neste trabalho abrem uma vasta gama de possíveis aplicações, nas quais as fibras ultrafinas e nanofibras, preparadas a partir da biomassa lignocelulósica, podem 
ser empregadas, tais como membranas, filmes em estruturas do tipo sanduíche ou mesmo como reforço em materiais compósitos. 


\section{CONCLUSÕES GERAIS}

Pode-se concluir que o presente trabalho, o qual visou à valorização da fibra lignocelulósica de sisal e de seu componente majoritário (celulose), atingiu as metas pretendidas. A síntese de ésteres de celulose, em meios homogêneo e heterogêneo, foi explorada de maneira a possibilitar o estabelecimento de importantes correlações quanto à obtenção de ésteres de diferentes tamanhos de cadeia e GS. Em meio homogêneo, a síntese de ésteres com diferentes tamanhos de cadeia (acetatos, butanoatos e hexanoatos) e com controle efetivo do GS, por meio do ajuste da razão $\mathrm{Mol}_{\text {Anidrido }} / \mathrm{Mol}_{\text {Celulose }}$, foi de extrema importância, pois permitiu o planejamento da etapa posterior, na qual estes ésteres foram empregados na preparação de filmes e biocompósitos, estes últimos consistindo da mistura de ésteres de celulose e celulose de sisal.

Em meio heterogêneo, a obtenção de acetatos de celulose com GS controlado, via catálise iodo, mostrou ser possível apenas variando-se o tempo de reação. Neste meio, o qual se mostrou mais seletivo quanto à obtenção de ésteres de cadeias mais longas, levou à busca de novas rotas de síntese, as quais necessitaram o envolvimento de diferentes agentes esterificantes, catalisadores e solventes que levassem ao intumescimento da massa celulósica, visando à ativação da mesma. Assim, a obtenção de butanoatos de celulose completamente substituídos foi possível em um tempo significativamente inferior (30 minutos) ao tempo necessário em meio homogêneo para atingir um GS 3,0 (I 2 h).

A preparação de filmes e biocompósitos, a partir de ésteres com diferentes tamanhos de cadeia (acetatos, butanoatos e hexanoatos), GS $(0,7-1,8)$ e quantidade de celulose $(0-20,0 \%)$, foi de fundamental importância no estudo das propriedades destes materiais. Importantes correlações foram possíveis com base em uma completa caracterização das propriedades mecânicas, morfológicas, térmicas e de superfície. Nesta direção, a grande variedade de propriedades apresentadas permite a preparação de materiais com características bem definidas, a partir da escolha de derivados específicos, com tamanhos de cadeia e GS controlados. No geral, os filmes preparados a partir de ésteres de celulose apresentaram baixas propriedades de tração, mas a celulose de sisal demonstrou ser um agente de reforço adequado para obtenção de materiais com melhores propriedades mecânicas, com a vantagem de se usar um processo de uma única etapa para a preparação 
do filme, o que não ocorre, por exemplo, quando nanocristais de celulose devem ser previamente preparados para serem usados com reforço em filmes.

Por meio de um estudo detalhado de pré-tratamento da massa celulósica em sistema etanol- $\mathrm{HCl}$, foi possível atingir condições ótimas na dissolução da celulose de sisal em sistema aquoso de $\mathrm{NaOH} /$ Uréia e posterior coagulação em meio ácido. Este processo permitiu a preparação controlada de microesferas de celulose, as quais apresentaram propriedades muito bem definidas, a partir do controle das propriedades do meio coagulante (concentração e temperatura). A preparação de microesferas a partir de celulose de sisal vêm em direção à aplicação destes materiais nos mais diversos campos, como na liberação controlada de fármacos, cromatografia ou mesmo como suporte para absorção/adsorção de nanopartículas, visando fornecer propriedades diversas (magnéticas, fluorescentes, dentre outras).

$\mathrm{Na}$ última etapa do trabalho, introduziu-se, de forma inédita até onde atinja o nosso conhecimento, um método para a eletrofiação da biomassa lignocelulósica não tratada, à temperatura ambiente. Por meio do uso do ácido trifluoroacético (TFA), a dissolução das fibras, pelo rompimento da estrutura lignocelulósica, foi realizada e seguida da posterior reconstrução via técnica de eletrofiação. Assim, fibras ultrafinas com diâmetros variando no intervalo de 120 a $510 \mathrm{~nm}$, sem a presença de resíduos não-eletrofiados, foram obtidas. A eletrofiação da celulose de sisal pode também ser realizada à temperatura ambiente e, além de fibras ultrafinas, nanofibras $(<100 \mathrm{~nm})$ foram geradas, apenas com ajustes na vazão da solução. Os resultados apresentados neste estudo abriram uma vasta gama de possíveis aplicações, nas quais as fibras ultrafinas e nanofibras, preparadas a partir da biomassa lignocelulósica, podem ser empregadas, tais como membranas, filmes em estruturas do tipo sanduíche ou mesmo como reforço em materiais compósitos.

Para finalizar, pode-se dizer que o presente trabalho contribuiu para ampliar o conhecimento nas áreas fundamentais da química da celulose, no que tange os tratamentos da massa celulósica, dissolução, derivatização e posterior aplicação da celulose e de seus derivados na preparação de diferentes materiais. Ao longo de todo o trabalho, os conhecimentos adquiridos têm gerado novas perspectivas na aplicação dos materiais preparados, assim como contribuído para perspectivas futuras de ampliação do conjunto considerado. Assim, em breves exemplos, pode-se citar a contribuição do conhecimento adquirido na eletrofiação da biomassa celulósica, a qual está sendo usada na preparação de 
membranas a partir da eletrofiação de soluções mistas de polímeros termoplásticos e fibras lignocelulósicas; uso dos ésteres de celulose, com diferentes tamanhos de cadeia e GS, na preparação de membranas eletrofiadas com propriedades diversificadas; microesferas de celulose de sisal como suporte para a adsorção/absorção de nanopartículas, visando fornecer propriedades magnéticas. 
P ág i n a | 238 


\section{REFERÊNCIAS BIBLIOGRÁFICAS}

ABE, K.; YANO, H. Comparison of the characteristics of cellulose microfibril aggregates isolated from fiber and parenchyma cells of moso bamboo (phyllostachys pubescens).

Cellulose, v. 17, n. 2, p. 271-277, 2010.

ADEL, A. M.; EL-WAHAB, Z. H. A.; IBRAHIM, A. A.; AL-SHEMY, M. T.

Characterization of microcrystalline cellulose prepared from lignocellulosic materials. Part i.

Acid catalyzed hydrolysis. Bioresource Technology, v. 101, n. 12, p. 4446-4455, 2010.

AHN, Y.; LEE, S. H.; KIM, H. J.; YANG, Y. H.; HONG, J. H.; KIM, Y. H.; KIM, H. Electrospinning of lignocellulosic biomass using ionic liquid. Carbohydrate Polymers, v. 88, n. 1, p. 395-398, 2012.

AL-ABDALLAH, W.; DAHMAN, Y. Production of green biocellulose nanofibers by gluconacetobacter xylinus through utilizing the renewable resources of agriculture residues.

Bioprocess and Biosystems Engineering, v. 36, n. 11, p. 1735-1743, 2013.

ALBUQUERQUE, T. L. D.; DA SILVA, I. J.; DE MACEDO, G. R.; ROCHA, M. V. P. Biotechnological production of xylitol from lignocellulosic wastes: A review. Process Biochemistry, v. 49, n. 11, p. 1779-1789, 2014.

ALMEIDA, E. V. R.; FROLLINI, E.; CASTELLAN, A.; COMA, V. Chitosan, sisal cellulose, and biocomposite chitosan/sisal cellulose films prepared from thiourea/naoh aqueous solution. Carbohydrate Polymers, v. 80, n. 3, p. 655-664, 2010.

ALMEIDA, E. V. R.; MORGADO, D. L.; RAMOS, L. A.; FROLLINI, E. Sisal cellulose and its acetates: Generation of films and reinforcement in a one-pot process. Cellulose, v. 20, n. 1, p. 453-465, 2013.

AMIM JR., J.; PETRI, D. F. S.; MAIA, F. C. B.; MIRANDA, P. B. Filmes ultrafinos de ésteres de celulose: Preparo, caracterização e imobilização de proteínas. Química Nova, v. 33, p. 2064-2069, 2010.

ASHFAQ, M.; KHAN, S.; VERMA, N. Synthesis of pva-cap-based biomaterial in situ dispersed with cu nanoparticles and carbon micro-nanofibers for antibiotic drug delivery applications. Biochemical Engineering Journal, v. 90, p. 79-89, 2014.

ASS, B. A. P.; CIACCO, G. T.; FROLLINI, E. Cellulose acetates from linters and sisal: Correlation between synthesis conditions in dmac/licl and product properties. Bioresource Technology, v. 97, n. 14, p. 1696-1702, 2006.

ASS, B. A. P.; FROLLINI, E.; HEINZE, T. Studies on the homogeneous acetylation of cellulose in the novel solvent dimethyl sulfoxide/tetrabutylammonium fluoride trihydrate. Macromolecular Bioscience, v. 4, n. 11, p. 1008-1013, 2004. 
ATALLA, R. H.; ISOGAI, A. Recent developments in spectroscopic and chemical characterization of cellulose. In: DEKKER, N. Y. M. (Ed.). Polysaccharides : Structural diversity and functional versatility. Boca Raton: CRC Press, 2005. p. 123-127.

AZIZI SAMIR, M. A. S.; ALLOIN, F.; DUFRESNE, A. Review of recent research into cellulosic whiskers, their properties and their application in nanocomposite field.

Biomacromolecules, v. 6, n. 2, p. 612-626, 2005.

BAI, Y.-X.; LI, Y.-F. Preparation and characterization of crosslinked porous cellulose beads. Carbohydrate Polymers, v. 64, n. 3, p. 402-407, 2006.

BAJEROVA, M.; KREJCOVA, K.; RABISKOVA, M.; MUSELIK, J.; DVORACKOVA, K.; GAJDZIOK, J.; MASTEIKOVA, R. Oxycellulose beads with drug exhibiting ph-dependent solubility. AAPS PharmSciTech, v. 12, n. 4, p. 1348-57, 2011.

BARTHEL, S.; HEINZE, T. Acylation and carbanilation of cellulose in ionic liquids. Green Chemistry, v. 8, n. 3, p. 301-306, 2006.

BARUD, H. S.; DE ARAÚJO JÚNIOR, A. M.; SANTOS, D. B.; DE ASSUNÇÃO, R. M. N.; MEIRELES, C. S.; CERQUEIRA, D. A.; RODRIGUES FILHO, G.; RIBEIRO, C. A.;

MESSADDEQ, Y.; RIBEIRO, S. J. L. Thermal behavior of cellulose acetate produced from homogeneous acetylation of bacterial cellulose. Thermochimica Acta, v. 471, n. 1-2, p. 6169, 2008.

BENDAHOU, A.; HAJLANE, A.; DUFRESNE, A.; BOUFI, S.; KADDAMI, H.

Esterification and amidation for grafting long aliphatic chains on to cellulose nanocrystals: A comparative study. Research on Chemical Intermediates, p. 1-18, 2014.

BHOWMICK, B.; BAIN, M. K.; MAITY, D.; BERA, N. K.; MONDAL, D.; MOLLICK, M. M. R.; MAITI, P. K.; CHATTOPADHYAY, D. Synthesis of dendritic polyaniline nanofibers by using soft template of sodium alginate. Journal of Applied Polymer Science, v. 123, n. 3, p. 1630-1635, 2012.

BISWAS, A.; SELLING, G.; APPELL, M.; WOODS, K. K.; WILLETT, J. L.; BUCHANAN, C. M. Iodine catalyzed esterification of cellulose using reduced levels of solvent.

Carbohydrate Polymers, v. 68, n. 3, p. 555-560, 2007.

BISWAS, A.; SHOGREN, R. L.; WILLETT, J. L. Solvent-free process to esterify polysaccharides $\dagger$. Biomacromolecules, v. 6, n. 4, p. 1843-1845, 2005.

BOTARO, V. R.; GANDINI, A.; BELGACEM, M. N. Heterogeneous chemical modification of cellulose for composite materials. Journal of Thermoplastic Composite Materials, v. 18, n. 2, p. 107-117, 2005.

BURCHARD, W. Solubility and solution structure of cellulose derivatives. Cellulose, v. 10, n. 3, p. 213-225, 2003.

BURTON, R. A.; GIDLEY, M. J.; FINCHER, G. B. Heterogeneity in the chemistry, structure and function of plant cell walls. Nature Chemical Biology, v. 6, n. 10, p. 724-732, 2010. 
BUSCHLE-DILLER, G.; ZERONIAN, S. H. Enhancing the reactivity and strength of cotton fibers. Journal of Applied Polymer Science, v. 45, n. 6, p. 967-979, 1992.

CAI, J.; ZHANG, L.; LIU, S.; LIU, Y.; XU, X.; CHEN, X.; CHU, B.; GUO, X.; XU, J.; CHENG, H.; HAN, C. C.; KUGA, S. Dynamic self-assembly induced rapid dissolution of cellulose at low temperatures. Macromolecules, v. 41, n. 23, p. 9345-9351, 2008.

CANEVAROLO JR., W. D. Técnicas de caracterização de polímeros. São Paulo: Ed. Artliber, 2007. 380 p.

CARLSSON, C. M. G.; STROEM, G. Reduction and oxidation of cellulose surfaces by means of cold plasma. Langmuir, v. 7, n. 11, p. 2492-2497, 1991.

CASARANO, R.; NAWAZ, H.; POSSIDONIO, S.; DA SILVA, V. C.; EL SEOUD, O. A. A convenient solvent system for cellulose dissolution and derivatization: Mechanistic aspects of the acylation of the biopolymer in tetraallylammonium fluoride/dimethyl sulfoxide.

Carbohydrate Polymers, v. 86, n. 3, p. 1395-1402, 2011.

CASTRO, D. O. Biocompósitos a partir de "polietileno verde", óleos vegetais, macro e nano fibras de curauá. 2014. 196f. (Tese) - Instituto de Química de São Carlos, Universidade de São Paulo, São Carlos, 2014.

CASTRO, D. O.; FROLLINI, E.; MARINI, J.; RUVOLO-FILHO, A. Preparation and characterization of biocomposites based on curaua fibers, high-density biopolyethylene (hdbpe) and liquid hydroxylated polybutadiene (lhpb). Polimeros, v. 23, n. 1, p. 65-73, 2013.

CHEN, L. F.; TSAO, G. T. Chemical procedures for enzyme immobilization on porous cellulose beads. Biotechnology and Bioengineering, v. 19, n. 10, p. 1463-1473, 1977.

CHEN, Q.; YANG, R.; ZHAO, B.; LI, Y.; WANG, S.; WU, H.; ZHUO, Y.; CHEN, C. Investigation of heat of biomass pyrolysis and secondary reactions by simultaneous thermogravimetry and differential scanning calorimetry. Fuel, v. 134, p. 467-476, 2014.

CHENG, Q.; WANG, S.; HAN, Q. Novel process for isolating fibrils from cellulose fibers by high-intensity ultrasonication. Ii. Fibril characterization. Journal of Applied Polymer Science, v. 115, n. 5, p. 2756-2762, 2010.

CHIA, A. C. E.; BOULANGER, J. P.; LAPIERRE, R. R. Unlocking doping and compositional profiles of nanowire ensembles using sims. Nanotechnology, v. 24, n. 4, p. 17, 2013.

CIACCO, G. T.; LIEBERT, T. F.; FROLLINI, E.; HEINZE, T. J. Application of the solvent dimethyl sulfoxide/tetrabutyl-ammonium fluoride trihydrate as reaction medium for the homogeneous acylation of sisal cellulose. Cellulose, v. 10, n. 2, p. 125-132, 2003.

CIACCO, G. T.; MORGADO, D. L.; FROLLINI, E.; POSSIDONIO, S.; EL SEOUD, O. A. Some aspects of acetylation of untreated and mercerized sisal cellulose. Journal of the Brazilian Chemical Society, v. 21, n. 1, p. 71-77, 2010. 
CRÉPY, L.; CHAVERIAT, L.; BANOUB, J.; MARTIN, P.; JOLY, N. Synthesis of cellulose fatty esters as plastics - influence of the degree of substitution and the fatty chain length on mechanical properties. ChemSusChem, v. 2, n. 2, p. 165-170, 2009.

DAWSEY, T. R.; MCCORMICK, C. L. Lithium chloride/dimethylacetamide solvent for cellulose. A literature review. Journal of Macromolecular Science - Reviews in Macromolecular Chemistry and Physics, v. C30, n. 3-4, p. 405-440, 1990.

DE OLIVEIRA SANTOS, R. P. Compósitos baseados em PET reciclado, fibras de sisal e plasticizantes oriundos de fontes renováveis. 2012. 157f. (Dissertação (Mestrado em Ciência e Engenharia de Materiais)) -, Universidade de São Paulo, São Carlos, 2012.

DE OLIVEIRA SANTOS, R. P.; OLIVEIRA CASTRO, D.; COLLÀ RUVOLO-FILHO, A.; FROLLINI, E. Processing and thermal properties of composites based on recycled pet, sisal fibers, and renewable plasticizers. Journal of Applied Polymer Science, v. 131, n. 12, p. 13, 2014.

DE OLIVEIRA SANTOS, R. P.; RODRIGUES, B. V. M.; RAMIRES, E. C.; RUVOLOFILHO, A.; FROLLINI, E. Electrospun nano/ultrafine fiber mats obtained from recycled pet and sisal fibers. 3rd International Polysaccharide Conference, 2013. Nice. p.368.

DE OLIVEIRA, W.; GLASSER, W. G. Hydrogels from polysaccharides. Ii. Beads with cellulose derivatives. Journal of Applied Polymer Science, v. 61, n. 1, p. 81-86, 1996.

DE PAULA, M. P.; LACERDA, T. M.; ZAMBON, M. D.; FROLLINI, E. Adding value to the brazilian sisal: Acid hydrolysis of its pulp seeking production of sugars and materials. Cellulose, v. 19, n. 3, p. 975-992, 2012.

DONG, D.; SUN, J.; HUANG, F.; GAO, Q.; WANG, Y.; LI, R. Using trifluoroacetic acid to pretreat lignocellulosic biomass. Biomass and Bioenergy, v. 33, n. 12, p. 1719-1723, 2009.

DORN, S.; PFEIFER, A.; SCHLUFTER, K.; HEINZE, T. Synthesis of water-soluble cellulose esters applying carboxylic acid imidazolides. Polymer Bulletin, v. 64, n. 9, p. 845$854,2010$.

DU, K.-F.; YAN, M.; WANG, Q.-Y.; SONG, H. Preparation and characterization of novel macroporous cellulose beads regenerated from ionic liquid for fast chromatography. Journal of Chromatography A, v. 1217, n. 8, p. 1298-1304, 2010.

DUAN, J.; WANG, Y.; WANG, Y.; XIONG, X. Preparation and characterization of cellulose-coated chitosan beads with improved strength and acid resistivity. Journal of Applied Polymer Science, v. 126, n. suppl. 1, p. E173-E179, 2012.

EBRINGEROVÁ, A.; HEINZE, T. Xylan and xylan derivatives - biopolymers with valuable properties, 1: Naturally occurring xylans structures, isolation procedures and properties. Macromolecular Rapid Communications, v. 21, n. 9, p. 542-556, 2000.

EDGAR, K. Cellulose esters in drug delivery. Cellulose, v. 14, n. 1, p. 49-64, 2007. 
EDGAR, K. J.; BUCHANAN, C. M.; DEBENHAM, J. S.; RUNDQUIST, P. A.; SEILER, B. D.; SHELTON, M. C.; TINDALL, D. Advances in cellulose ester performance and application. Progress in Polymer Science, v. 26, n. 9, p. 1605-1688, 2001.

EL-KAFRAWY, A. Investigation of the cellulose/licl/dimethylacetamide and cellulose/licl/nmethyl-2-pyrrolidinone solutions by **1**3c nmr spectroscopy. Journal of Applied Polymer Science, v. 27, n. 7, p. 2435-2443, 1982.

EL SEOUD, O. A.; NAWAZ, H.; AREAS, E. P. Chemistry and applications of polysaccharide solutions in strong electrolytes/dipolar aprotic solvents: An overview.

Molecules, v. 18, n. 1, p. 1270-313, 2013.

ENTOV, V. M.; SHMARYAN, L. E. Numerical modeling of the capillary breakup of jets of polymeric liquids. Fluid Dynamics, v. 32, n. 5, p. 696-703, 1997.

EPSTEIN, E. Silicon in plants: Facts vs. Concepts. In: L.E. DATNOFF, G. H. S.;

KORNDÖRFER, G. H. (Ed.). Studies in plant science. Amsterdam: Elsevier, 2001. v.8, p. 115.

ETTENAUER, M.; LOTH, F.; THÜMMLER, K.; FISCHER, S.; WEBER, V.;

FALKENHAGEN, D. Characterization and functionalization of cellulose microbeads for extracorporeal blood purification. Cellulose, v. 18, n. 5, p. 1257-1263, 2011.

EYLEY, S.; THIELEMANS, W. Surface modification of cellulose nanocrystals. Nanoscale, v. 6, n. 14, p. 7764-7779, 2014.

FANG, X.; RENEKER, D. H. DNA fibers by electrospinning. Journal of Macromolecular Science, Part B, v. 36, n. 2, p. 169-173, 1997.

FANTA, G. F.; ABBOTT, T. P.; HERMAN, A. I.; BURR, R. C.; DOANE, W. M. Hydrolysis of wheat straw hemicellulose with trifluoroacetic acid. Fermentation of xylose with pachysolen tannophilus. Biotechnol Bioeng, v. 26, n. 9, p. 1122-5, 1984.

FENG, L.; LI, S. H.; ZHAI, J.; SONG, Y. L.; JIANG, L.; ZHU, D. B. Template based synthesis of aligned polyacrylonitrile nanofibers using a novel extrusion method. Synthetic Metals, v. 135-136, p. 817-818, 2003.

FENGEL, D.; WEGENER, G. Wood: Chemistry, ultrastructure, reactions. Berlin: Walter de Gruyter, 1983. $613 \mathrm{p}$.

FLAQUÉ, C.; MONTSERRAT, S. Thermal degradation of celluloses and their vinylic copolymers by thermogravimetric analysis. Journal of Applied Polymer Science, v. 74, n. 1, p. 201-209, 1999.

FONG, H.; CHUN, I.; RENEKER, D. H. Beaded nanofibers formed during electrospinning. Polymer, v. 40, n. 16, p. 4585-4592, 1999.

FREIRE, C. S. R.; GANDINI, A. Recent advances in the controlled heterogeneous modification of cellulose for the development of novel materials. Cellulose Chemistry and Technology, v. 40, n. 9-10, p. 691-698, 2006. 
FREIRE, C. S. R.; SILVESTRE, A. J. D.; NETO, C. P.; BELGACEM, M. N.; GANDINI, A. Controlled heterogeneous modification of cellulose fibers with fatty acids: Effect of reaction conditions on the extent of esterification and fiber properties. Journal of Applied Polymer Science, v. 100, n. 2, p. 1093-1102, 2006.

FREIRE, C. S. R.; SILVESTRE, A. J. D.; PASCOAL NETO, C.; GANDINI, A.; FARDIM, P.; HOLMBOM, B. Surface characterization by xps, contact angle measurements and tof-sims of cellulose fibers partially esterified with fatty acids. Journal of Colloid and Interface Science, v. 301, n. 1, p. 205-209, 2006.

FRENOT, A.; HENRIKSSON, M. W.; WALKENSTRÖM, P. Electrospinning of cellulosebased nanofibers. Journal of Applied Polymer Science, v. 103, n. 3, p. 1473-1482, 2007.

FREUDENBERG, K.; CHEN, C. L.; HARKIN, J. M.; NIMZ, H.; RENNER, H. Observation on lignin. Chemical Communications (London), n. 11, p. 224-225, 1965.

FREUDENBERG, K.; NIMZ, H. A further proof of the identity of natural and biosynthetic lignin. Chemical Communications (London), n. 5, p. 132-133, 1966.

FUJISAWA, S.; SAITO, T.; KIMURA, S.; IWATA, T.; ISOGAI, A. Comparison of mechanical reinforcement effects of surface-modified cellulose nanofibrils and carbon nanotubes in plla composites. Composites Science and Technology, v. 90, p. 96-101, 2014.

FUKAYA, Y.; HAYASHI, K.; WADA, M.; OHNO, H. Cellulose dissolution with polar ionic liquids under mild conditions: Required factors for anions. Green Chemistry, v. 10, n. 1, p. 44-46, 2008.

GAO, Y.; TRUONG, Y. B.; ZHU, Y.; LOUIS KYRATZIS, I. Electrospun antibacterial nanofibers: Production, activity, and in vivo applications. Journal of Applied Polymer Science, v. 131, n. 18, p. 9041-9053, 2014.

GARARD, I. D. The preparation and properties of colloidal and monoclinic sulfur in organic liquids. Journal of the American Chemical Society, v. 49, n. 3, p. 630-636, 1927.

GERICKE, M.; TRYGG, J.; FARDIM, P. Functional cellulose beads: Preparation, characterization, and applications. Chemical Reviews, v. 113, n. 7, p. 4812-4836, 2013.

GHAEMI, N.; MADAENI, S. S.; ALIZADEH, A.; DARAEI, P.; ZINATIZADEH, A. A.; RAHIMPOUR, F. Separation of nitrophenols using cellulose acetate nanofiltration membrane: Influence of surfactant additives. Separation and Purification Technology, v. 85 , p. 147-156, 2012.

GHOLAMI, A.; TAVANAI, H.; MORADI, A. R. Production of fibroin nanopowder through electrospraying. Journal of Nanoparticle Research, v. 13, n. 5, p. 2089-2098, 2011.

GLASSER, W. G.; TAIB, R.; JAIN, R. K.; KANDER, R. Fiber-reinforced cellulosic thermoplastic composites. Journal of Applied Polymer Science, v. 73, n. 7, p. 1329-1340, 1999. 
GOACHER, R. E.; EDWARDS, E. A.; YAKUNIN, A. F.; MIMS, C. A.; MASTER, E. R. Application of time-of-flight-secondary ion mass spectrometry for the detection of enzyme activity on solid wood substrates. Analytical Chemistry, v. 84, n. 10, p. 4443-51, 2012.

GOMES, G. S.; DE ALMEIDA, A. T.; KOSAKA, P. M.; ROGERO, S. O.; CRUZ, A. S.; IKEDA, T. I.; PETRI, D. F. S. Cellulose acetate propionate coated titanium: Characterization and biotechnological application. Materials Research, v. 10, n. 4, p. 5, 2007.

GÓMEZ-CARRACEDO, A.; ALVAREZ-LORENZO, C.; GÓMEZ-AMOZA, J. L.; CONCHEIRO, A. Chemical structure and glass transition temperature of non-ionic cellulose ethers. Journal of Thermal Analysis and Calorimetry, v. 73, n. 2, p. 587-596, 2003.

GONTE, R. R.; BALASUBRAMANIAN, K.; MUMBREKAR, J. D. Porous and cross-linked cellulose beads for toxic metal ion removal: $\mathrm{Hg}(\mathrm{ii})$ ions. Journal of Polymers, v. 2013, p. 9, 2013.

GREINER, A.; WENDORFF, J. H. Electrospinning: A fascinating method for the preparation of ultrathin fibers. Angewandte Chemie International Edition, v. 46, n. 30, p. 5670-5703, 2007.

GRUNDKE, K.; BOGUMIL, T.; WERNER, C.; JANKE, A.; PÖSCHEL, K.; JACOBASCH, H. J. Liquid-fluid contact angle measurements on hydrophilic cellulosic materials. Colloids and Surfaces A: Physicochemical and Engineering Aspects, v. 116, n. 1-2, p. 79-91, 1996.

GUEZGUEZ, I.; MRABET, B.; FERJANI, E. Xps and contact angle characterization of surface modified cellulose acetate membranes by mixtures of pmhs/pdms. Desalination, $v$. 313, p. 208-211, 2013.

HABIBI, Y. Key advances in the chemical modification of nanocelluloses. Chemical Society Reviews, v. 43, n. 5, p. 1519-1542, 2014.

HAHN-HÄGERDAL, B.; GALBE, M.; GORWA-GRAUSLUND, M. F.; LIDÉN, G.; ZACCHI, G. Bio-ethanol - the fuel of tomorrow from the residues of today. Trends in Biotechnology, v. 24, n. 12, p. 549-556, 2006.

HALIDAN, M.; KURBANJIAN, R.; ABLIMIT; AYNUR. Homogeneous synthesis of longchain fatty acid esters of cellulose by using co-reagent. Huagong Xuebao/CIESC Journal, v. 61, n. 11, p. 3014-3019, 2010.

HÄRDELIN, L.; THUNBERG, J.; PERZON, E.; WESTMAN, G.; WALKENSTRÖM, P.; GATENHOLM, P. Electrospinning of cellulose nanofibers from ionic liquids: The effect of different cosolvents. Journal of Applied Polymer Science, v. 125, n. 3, p. 1901-1909, 2012.

HARNED, H. S.; FLEYSHER, M. H. The activity coefficients of hydrochloric acid in solutions of ethyl alcohol. Journal of the American Chemical Society, v. 47, n. 1, p. 82-92, 1925.

HASEGAWA, M.; ISOGAI, A.; ONABE, F.; USUDA, M. Dissolving states of cellulose and chitosan in trifluoroacetic acid. Journal of Applied Polymer Science, v. 45, n. 10, p. 1857$1863,1992$. 
HE, Y. Z.; PANG, H.; LIAO, B.; HU, M. L. Preparation of cellulose benzoate used as chiral stationary phases. Gaofenzi Cailiao Kexue Yu Gongcheng/Polymeric Materials Science and Engineering, v. 23, n. 1, p. 72-75, 2007.

HEINZE, T.; LIEBERT, T. Unconventional methods in cellulose functionalization. Progress in Polymer Science, v. 26, n. 9, p. 1689-1762, 2001.

HIROTA, M.; TAMURA, N.; SAITO, T.; ISOGAI, A. Surface carboxylation of porous regenerated cellulose beads by 4 -acetamide-tempo/naclo/naclo2 system. Cellulose, v. 16, n. 5 , p. 841-851, 2009.

HO, J. A. A.; WAUCHOPE, R. D. A strip liposome immunoassay for aflatoxin b1. Analytical Chemistry, v. 74, n. 7, p. 1493-1496, 2002.

HOMAYONI, H.; RAVANDI, S. A. H.; VALIZADEH, M. Electrospinning of chitosan nanofibers: Processing optimization. Carbohydrate Polymers, v. 77, n. 3, p. 656-661, 2009.

HUANG, Z. M.; ZHANG, Y. Z.; KOTAKI, M.; RAMAKRISHNA, S. A review on polymer nanofibers by electrospinning and their applications in nanocomposites. Composites Science and Technology, v. 63, n. 15, p. 2223-2253, 2003.

HUI, W. X., H. Q.;JIAN, H. C. Study on structures of electrospinning cellulose acetate nanofibers. Advanced Materials Research, v. 175-176, p. 242-246, 2011.

HULT, E. L.; LARSSON, P. T.; IVERSEN, T. Cellulose fibril aggregation - an inherent property of kraft pulps. Polymer, v. 42, n. 8, p. 3309-3314, 2001.

ISOBE, N.; CHEN, X.; KIM, U. J.; KIMURA, S.; WADA, M.; SAITO, T.; ISOGAI, A. Tempo-oxidized cellulose hydrogel as a high-capacity and reusable heavy metal ion adsorbent. Journal of Hazardous Materials, v. 260, p. 195-201, 2013.

ISOBE, N.; NOGUCHI, K.; NISHIYAMA, Y.; KIMURA, S.; WADA, M.; KUGA, S. Role of urea in alkaline dissolution of cellulose. Cellulose, v. 20, n. 1, p. 97-103, 2013.

IWAMOTO, S.; KAI, W.; ISOGAI, T.; SAITO, T.; ISOGAI, A.; IWATA, T. Comparison study of tempo-analogous compounds on oxidation efficiency of wood cellulose for preparation of cellulose nanofibrils. Polymer Degradation and Stability, v. 95, n. 8, p. 13941398, 2010.

JAEGER, R.; BERGSHOEF, M. M.; BATLLE, C. M. I.; SCHÖNHERR, H.; JULIUS VANCSO, G. Electrospinning of ultra-thin polymer fibers. Macromolecular Symposia, v. 127, n. 1, p. 141-150, 1998.

JANDURA, P.; KOKTA, B. V.; RIEDL, B. Fibrous long-chain organic acid cellulose esters and their characterization by diffuse reflectance ftir spectroscopy, solid-state $\mathrm{cp} / \mathrm{mas} 13 \mathrm{c}-\mathrm{nmr}$, and x-ray diffraction. Journal of Applied Polymer Science, v. 78, n. 7, p. 1354-1365, 2000. 
JANG, S.-W.; KIM, J.-C.; CHANG, J.-H. Preparation and characterization of cellulose nanocomposite films with two different organo-micas. Cellulose, v. 16, n. 3, p. 445-454, 2009.

JOHNSTON, J. H.; NILSSON, T. Nanogold and nanosilver composites with lignincontaining cellulose fibres. Journal of Materials Science, v. 47, n. 3, p. 1103-1112, 2012.

JUNG, S.; FOSTON, M.; KALLURI, U. C.; TUSKAN, G. A.; RAGAUSKAS, A. J. 3d chemical image using tof-sims revealing the biopolymer component spatial and lateral distributions in biomass. Angewandte Chemie - International Edition, v. 51, n. 48, p. 12005-12008, 2012.

KANG, V. S.; KIM, H. Y.; RYU, Y. J.; LEE, D. R. Manufacturing the cellulose web by using electro-spinning and in-vitro behaviour of oxidized cellulose web. Journal of the Korean Fiber Society, v. 39, p. 7, 2002.

KANG, Y.; AHN, Y.; LEE, S. H.; HONG, J. H.; KU, M. K.; KIM, H. Lignocellulosic nanofiber prepared by alkali treatment and electrospinning using ionic liquid. Fibers and Polymers, v. 14, n. 4, p. 530-536, 2013.

KARRER, P.; WIDMER, F. Polysaccharide ix. Zur kenntnis der cellulose und des lignins. Helvetica Chimica Acta, v. 4, n. 1, p. 700-702, 1921.

KASCHUK, J. J. Hidrólise enzimática da polpa celulósica de sisal. 2014. 170f. Dissertação (Mestrado) - Instituto de Química de São Carlos, Universidade de São Paulo, São Carlos, 2014.

KIM, C. W.; KIM, D. S.; KANG, S. Y.; MARQUEZ, M.; JOO, Y. L. Structural studies of electrospun cellulose nanofibers. Polymer, v. 47, n. 14, p. 5097-5107, 2006.

KIM, M. S.; KIM, G. Three-dimensional electrospun polycaprolactone (pcl)/alginate hybrid composite scaffolds. Carbohydrate Polymers, v. 114, p. 213-221, 2014.

KIM, S.; DALE, B. E. Global potential bioethanol production from wasted crops and crop residues. Biomass and Bioenergy, v. 26, n. 4, p. 361-375, 2004.

KIM, W. G.; LEE, J. S.; BUCKNALL, D. G.; KOROS, W. J.; NAIR, S. Nanoporous layered silicate amh-3/cellulose acetate nanocomposite membranes for gas separations. Journal of Membrane Science, v. 441, p. 129-136, 2013.

KINGSHOTT, P.; ANDERSSON, G.; MCARTHUR, S. L.; GRIESSER, H. J. Surface modification and chemical surface analysis of biomaterials. Current Opinion in Chemical Biology, v. 15, n. 5, p. 667-676, 2011.

KLEMM, D.; HEUBLEIN, B.; FINK, H. P.; BOHN, A. Cellulose: Fascinating biopolymer and sustainable raw material. Angewandte Chemie - International Edition, v. 44, n. 22, p. 3358-3393, 2005. 
KLEMM, D.; PHILIPP, B.; HEINZE, T.; HEINZE, U.; WAGENKNECHT, W. General considerations on structure and reactivity of cellulose: Section 2.1-2.1.4. In: (Ed.).

Comprehensive cellulose chemistry. New York: Wiley-VCH, 2004. p. 9-29.

KOSAKA, P. M.; KAWANO, Y.; EL SEOUD, O. A.; PETRI, D. F. S. Catalytic activity of lipase immobilized onto ultrathin films of cellulose esters. Langmuir, v. 23, n. 24, p. 12167 12173, 2007.

KOVAČ, J. Surface characterization of polymers by xps and sims techniques. Materiali in Tehnologije, v. 45, n. 3, p. 191-197, 2011.

KROGSTAD, E. A.; WOODROW, K. A. Manufacturing scale-up of electrospun poly(vinyl alcohol) fibers containing tenofovir for vaginal drug delivery. International Journal of Pharmaceutics, v. 475, n. 1, p. e282-e291, 2014.

KROON-BATENBURG, L. M. J.; KROON, J. The crystal and molecular structures of cellulose i and ii. Glycoconjugate Journal, v. 14, n. 5, p. 677-690, 1997.

KROUIT, M.; GRANET, R.; KRAUSZ, P. Photobactericidal plastic films based on cellulose esterified by chloroacetate and a cationic porphyrin. Bioorganic \& Medicinal Chemistry v. 16, n. 23, p. 10091-10097, 2008.

KROUIT, M.; GRANET, R.; KRAUSZ, P. Photobactericidal films from porphyrins grafted to alkylated cellulose - synthesis and bactericidal properties. European Polymer Journal, v. 45, n. 4, p. 1250-1259, 2009.

KUNZE, J.; FINK, H. P. Structural changes and activation of cellulose by caustic soda solution with urea. Macromolecular Symposia, v. 223, p. 175-187, 2005.

LACERDA, T. M.; ZAMBON, M. D.; FROLLINI, E. Effect of acid concentration and pulp properties on hydrolysis reactions of mercerized sisal. Carbohydrate Polymers, v. 93, n. 1, p. 347-356, 2013.

LEE, K.-Y.; BLAKER, J. J.; BISMARCK, A. Surface functionalisation of bacterial cellulose as the route to produce green polylactide nanocomposites with improved properties.

Composites Science and Technology, v. 69, n. 15-16, p. 2724-2733, 2009.

LEE, Y. Y.; IYER, P.; TORGET, R. W. Dilute-acid hydrolysis of lignocellulosic biomass. In: TSAO, G. T.; BRAINARD, A. P.; BUNGAY, H. R.; CAO, N. J.; CEN, P.; CHEN, Z.; DU, J.; FOODY, B.; GONG, C. S.; HALL, P.; HO, N. W. Y.; IRWIN, D. C.; IYER, P.; JEFFRIES, T. W.; LADISCH, C. M.; LADISCH, M. R.; LEE, Y. Y.; MOSIER, N. S.; MÜHLEMANN, H. M.; SEDLAK, M.; SHI, N. Q.; TSAO, G. T.; TOLAN, J. S.; TORGET, R. W.; WILSON, D. B.; XIA, L. (Ed.). Recent progress in bioconversion of lignocellulosics. Berlin: Springer, 1999. v. 65 , p. $93-115$.

LI, B.; KONECKE, S.; WEGIEL, L. A.; TAYLOR, L. S.; EDGAR, K. J. Both solubility and chemical stability of curcumin are enhanced by solid dispersion in cellulose derivative matrices. Carbohydrate Polymers, v. 98, n. 1, p. 1108-1116, 2013. 
LI, D.; XIA, Y. Electrospinning of nanofibers: Reinventing the wheel? Advanced Materials, v. 16, n. 14, p. 1151-1170, 2004.

LI, W.; WU, Y.; LIANG, W.; LI, B.; LIU, S. Reduction of the water wettability of cellulose film through controlled heterogeneous modification. ACS Applied Materials and Interfaces, v. 6, n. 8, p. 5726-5734, 2014.

LIM, Y.-M.; GWON, H.-J.; JEUN, J. P.; NHO, Y.-C. Preparation of cellulose-based nanofibers using electrospinning. Rijeka: InTech, 2010. p. Disponível em: < http://www.intechopen.com/books/export/citation/EndNote/nanofibers/preparation-ofcellulose-based-nanofibers-using-electrospinning >. Acesso em: 5 out. 2014.

LIN, J.-H.; CHANG, Y.-H.; HSU, Y.-H. Degradation of cotton cellulose treated with hydrochloric acid either in water or in ethanol. Food Hydrocolloids, v. 23, n. 6, p. 1548$1553,2009$.

LINDMAN, B.; KARLSTRÖM, G.; STIGSSON, L. On the mechanism of dissolution of cellulose. Journal of Molecular Liquids, v. 156, n. 1, p. 76-81, 2010.

LINKO, Y.-Y.; VISKARI, R.; POHJOLA, L.; LINKO, P. Preparation and performance of cellulose bead-entrapped whole cell glucose isomerase. Journal of Solid-Phase

Biochemistry, v. 2, n. 3, p. 203-212, 1977.

LIU, D.; ZHONG, T.; CHANG, P. R.; LI, K.; WU, Q. Starch composites reinforced by bamboo cellulosic crystals. Bioresource Technology, v. 101, n. 7, p. 2529-2536, 2010.

LIU, G.; DING, J.; QIAO, L.; GUO, A.; DYMOV, B. P.; GLEESON, J. T.; HASHIMOTO, T.; SAIJO, K. Polystyrene-block-pory(2-cinnamoylethyl methacrylate) nanofibers preparation, characterization, and liquid crystalline properties. Chemistry - A European Journal, v. 5, n. 9, p. 2740-2749, 1999.

LIU, G.; DU, S. Fabrication of aluminiferous nanofibers by simple hydrolysis of nano-sized al/aln powder. Advanced Materials Research, v. 430-432, p. 790-794, 2012.

LIU, P.; OUYANG, Y.; XIAO, R. Fabrication and morphology development of isotactic polypropylene nanofibers from isotactic polypropylene/polylactide blends. Journal of Applied Polymer Science, v. 123, n. 5, p. 2859-2866, 2012.

LU, Y.; TEKINALP, H. L.; EBERLE, C. C.; PETER, W.; NASKAR, A. K.; OZCAN, S. Nanocellulose in polymer composites and biomedical applications. Tappi Journal, v. 13, n. 6, p. 47-54, 2014.

LUCENA, M. D. C. C.; V. DE ALENCAR, A. E.; MAZZETO, S. E.; SOARES, S. D. A. The effect of additives on the thermal degradation of cellulose acetate. Polymer Degradation and Stability, v. 80, n. 1, p. 149-155, 2003.

LYND, L. R.; WEIMER, P. J.; VAN ZYL, W. H.; PRETORIUS, I. S. Microbial cellulose utilization: Fundamentals and biotechnology. Microbiology and Molecular Biology Reviews, v. 66, n. 3, p. 506-577, 2002. 
LYND, L. R.; ZYL, W. H. V.; MCBRIDE, J. E.; LASER, M. Consolidated bioprocessing of cellulosic biomass: An update. Current Opinion in Biotechnology, v. 16, n. 5, p. 577-583, 2005 .

LYONS, J.; LI, C.; KO, F. Melt-electrospinning part i: Processing parameters and geometric properties. Polymer, v. 45, n. 22, p. 7597-7603, 2004.

MA, P. X.; ZHANG, R. Synthetic nano-scale fibrous extracellular matrix. Journal of Biomedical Materials Research, v. 46, n. 1, p. 60-72, 1999.

MAGALHÃES, W. L. E.; CAO, X.; LUCIA, L. A. Cellulose nanocrystals/cellulose core-inshell nanocomposite assemblies. Langmuir, v. 25, n. 22, p. 13250-13257, 2009.

MAHAPATRA, A.; GARG, N.; NAYAK, B. P.; MISHRA, B. G.; HOTA, G. Studies on the synthesis of electrospun pan-ag composite nanofibers for antibacterial application. Journal of Applied Polymer Science, v. 124, n. 2, p. 1178-1185, 2012.

MAMAT, H.; ROUZ, K.; ABLIMIT; AYNUR. Homogeneous synthesis of long-chain fatty acid cellulose esters with p-toluenesulfonyl chlorid as coreactant. Shiyou

Huagong/Petrochemical Technology, v. 39, n. 9, p. 1040-1045, 2010.

MANSIKKAMÄKI, P.; LAHTINEN, M.; RISSANEN, K. Structural changes of cellulose crystallites induced by mercerisation in different solvent systems; determined by powder Xray diffraction method. Cellulose, v. 12, n. 3, p. 233-242, 2005.

MANTANIS, G. I.; YOUNG, R. A.; ROWELL, R. M. Swelling of compressed cellulose fiber webs in organic liquids. Cellulose, v. 2, n. 1, p. 1-22, 1995.

MARTÍNEZ-SANZ, M.; OLSSON, R. T.; LOPEZ-RUBIO, A.; LAGARON, J. M. Development of bacterial cellulose nanowhiskers reinforced evoh composites by electrospinning. Journal of Applied Polymer Science, v. 124, n. 2, p. 1398-1408, 2012.

MATSUMURA, H.; SUGIYAMA, J.; GLASSER, W. G. Cellulosic nanocomposites. I. Thermally deformable cellulose hexanoates from heterogeneous reaction. Journal of Applied Polymer Science, v. 78, n. 13, p. 2242-2253, 2000.

MCCORMICK, C. L.; LICHATOWICH, D. K. Homogeneous solution reactions of cellulose, chitin, and other polysaccharides to produce controlled-activity pesticide systems. Journal of Polymer Science: Polymer Letters Edition, v. 17, n. 8, p. 479-484, 1979.

MEGIATTO, J. J. D.; HOAREAU, W.; GARDRAT, C.; FROLLINI, E.; CASTELLAN, A. Sisal fibers: Surface chemical modification using reagent obtained from a renewable source; characterization of hemicellulose and lignin as model study. Journal of Agricultural and Food Chemistry, v. 55, n. 21, p. 8576-8584, 2007.

MEGIATTO JR, J. D.; HOAREAU, W.; GARDRAT, C.; FROLLINI, E.; CASTELLAN, A. Sisal fibers: Surface chemical modification using reagent obtained from a renewable source; characterization of hemicellulose and lignin as model study. Journal of Agricultural and Food Chemistry, v. 55, n. 21, p. 8576-8584, 2007. 
MEGIATTO JR, J. D.; SILVA, C. G.; ROSA, D. S.; FROLLINI, E. Sisal chemically modified with lignins: Correlation between fibers and phenolic composites properties. Polymer Degradation and Stability, v. 93, n. 6, p. 1109-1121, 2008.

MELCHER, J. R.; TAYLOR, G. I. Electrohydrodynamics - a review of role of interfacial shear stresses. Annual Review of Fluid Mechanics, v. 1, p. 111-\&, 1969.

MOHAMMADI, T.; SALJOUGHI, E. Effect of production conditions on morphology and permeability of asymmetric cellulose acetate membranes. Desalination, v. 243, n. 1-3, p. 1-7, 2009.

MOHANTY, A. K.; WIBOWO, A.; MISRA, M.; DRZAL, L. T. Development of renewable resource-based cellulose acetate bioplastic: Effect of process engineering on the performance of cellulosic plastics. Polymer Engineering \& Science, v. 43, n. 5, p. 1151-1161, 2003.

MONTAÑO-LEYVA, B.; RODRIGUEZ-FELIX, F.; TORRES-CHÁVEZ, P.; RAMIREZWONG, B.; LÓPEZ-CERVANTES, J.; SANCHEZ-MACHADO, D. Preparation and characterization of durum wheat (triticum durum) straw cellulose nanofibers by

electrospinning. Journal of Agricultural and Food Chemistry, v. 59, n. 3, p. 870-875, 2011.

MOON, R. J.; MARTINI, A.; NAIRN, J.; SIMONSEN, J.; YOUNGBLOOD, J. Cellulose nanomaterials review: Structure, properties and nanocomposites. Chemical Society Reviews, v. 40, n. 7, p. 3941-3994, 2011.

MORGADO, D. L.; FROLLINI, E. Thermal decomposition of mercerized linter cellulose and its acetates obtained from a homogeneous reaction. Polimeros, v. 21, n. 2, p. 111-117, 2011.

MORGADO, D. L.; FROLLINI, E.; CASTELLAN, A.; ROSA, D. S.; COMA, V. Biobased films prepared from naoh/thiourea aqueous solution of chitosan and linter cellulose.

Cellulose, v. 18, n. 3, p. 699-712, 2011.

MORGADO, D. L.; MARTINS, V. C. A.; PLEPIS, A. M. G.; FROLLINI, E. Aggregation of chains of cellulose acetates in licl/dmac: Evaluation via viscometry. Agregação de cadeias de acetatos de celulose em LiCl/DMAc: Avaliação via viscosimetria, v. 21, n. 2, p. 143-145, 2011.

MORGADO, D. L.; RODRIGUES, B. V. M.; ALMEIDA, E. V. R.; EL SEOUD, O. A.; FROLLINI, E. Bio-based films from linter cellulose and its acetates: Formation and properties. Materials, v. 6, p. 2410-2435, 2013.

MORGENSTERN, B.; KAMMER, H. W. On the particulate structure of cellulose solutions. Polymer, v. 40, n. 5, p. 1299-1304, 1999.

MORRISON, I. M.; STEWART, D. Plant cell wall fragments released on solubilisation in trifluoroacetic acid. Phytochemistry, v. 49, n. 6, p. 1555-1563, 1998.

MOSIER, N.; WYMAN, C.; DALE, B.; ELANDER, R.; LEE, Y. Y.; HOLTZAPPLE, M.; LADISCH, M. Features of promising technologies for pretreatment of lignocellulosic biomass. Bioresource Technology, v. 96, n. 6, p. 673-686, 2005. 
MUNIR, M. M.; SURYAMAS, A. B.; ISKANDAR, F.; OKUYAMA, K. Scaling law on particle-to-fiber formation during electrospinning. Polymer, v. 50, n. 20, p. 4935-4943, 2009.

NATARAJ, S. K.; ROY, S.; PATIL, M. B.; NADAGOUDA, M. N.; RUDZINSKI, W. E.; AMINABHAVI, T. M. Cellulose acetate-coated $\alpha$-alumina ceramic composite tubular membranes for wastewater treatment. Desalination, v. 281, n. 1, p. 348-353, 2011.

NIMZ, H. Beech lignin - proposal of a constitutional scheme. Angewandte Chemie International Edition in English, v. 13, n. 5, p. 313-321, 1974.

NOGI, M.; IWAMOTO, S.; NAKAGAITO, A. N.; YANO, H. Optically transparent nanofiber paper. Advanced Materials, v. 21, n. 16, p. 1595-1598, 2009.

O'NEILL JR., J. J.; REICHARDT, E. P. Method of producing cellulose pellets. US n.2543928A, 6 mar 1951.

OCHANDA, F. O.; SAMAHA, M. A.; TAFRESHI, H. V.; TEPPER, G. C.; GAD-EL-HAK, M. Fabrication of superhydrophobic fiber coatings by dc-biased ac-electrospinning. Journal of Applied Polymer Science, v. 123, n. 2, p. 1112-1119, 2012.

OHKAWA, K.; HAYASHI, S.; NISHIDA, A.; YAMAMOTO, H.; DUCREUX, J.

Preparation of pure cellulose nanofiber via electrospinning. Textile Research Journal, v. 79, n. 15, p. 1396-1401, 2009.

OKAMURA, K.; NORIMOTO, M.; SHIRAISHI, N. Change of x-ray diffraction peaks in aliphatic cellulose ester homologues. Wood Research, n. 69, p. 89-90, 1983.

ORBLIN, E.; ETA, V.; FARDIM, P. Surface chemistry of vessel elements by fe-sem, $\mu$-xps and tof-sims. Holzforschung, v. 65, n. 5, p. 681-688, 2011.

ORNAGHI, H., JR.; POLETTO, M.; ZATTERA, A.; AMICO, S. Correlation of the thermal stability and the decomposition kinetics of six different vegetal fibers. Cellulose, v. 21, n. 1, p. 177-188, 2014.

OUAJAI, S.; SHANKS, R. A. Preparation, structure and mechanical properties of all-hemp cellulose biocomposites. Composites Science and Technology, v. 69, p. 2119-2126, 2009.

PALMQVIST, E.; HAHN-HÄGERDAL, B. Fermentation of lignocellulosic hydrolysates. Ii: Inhibitors and mechanisms of inhibition. Bioresource Technology, v. 74, n. 1, p. 25-33, 2000 .

PARK, J. Y.; HAN, S. W.; LEE, I. H. Preparation of electrospun porous ethyl cellulose fiber by thf/dmac binary solvent system. Journal of Industrial and Engineering Chemistry, v. 13, n. 6, p. 1002-1008, 2007.

PERES DE PAULA, M.; LACERDA, T. M.; FROLLINI, E. Sisal cellulose acetates obtained from heterogeneous reactions. Express Polymer Letters, v. 2, n. 6, p. 423-428, 2008. 
PEŠKA, J.; ŠTAMBERG, J.; HRADIL, J.; ILAVSKÝ, M. Cellulose in bead form : Properties related to chromatographic uses. Journal of Chromatography A, v. 125, n. 3, p. 455-469, 1976.

POHL, M.; SCHALLER, J.; MEISTER, F.; HEINZE, T. Novel bulky esters of biopolymers: Dendritic cellulose. Macromolecular Symposia, v. 262, n. 1, p. 119-128, 2008.

POSSIDONIO, S.; FIDALE, L. C.; EL SEOUD, O. A. Microwave-assisted derivatization of cellulose in an ionic liquid: An efficient, expedient synthesis of simple and mixed carboxylic esters. Journal of Polymer Science Part A: Polymer Chemistry, v. 48, n. 1, p. 134-143, 2010.

PRONIEWICZ, L. M.; PALUSZKIEWICZ, C.; WESEŁUCHA-BIRCZYŃSKA, A.; MAJCHERCZYK, H.; BARAŃSKI, A.; KONIECZNA, A. Ft-ir and ft-raman study of hydrothermally degradated cellulose. Journal of Molecular Structure, v. 596, n. 1-3, p. 163-169, 2001.

QI, H.; CHANG, C.; ZHANG, L. Effects of temperature and molecular weight on dissolution of cellulose in naoh/urea aqueous solution. Cellulose, v. 15, n. 6, p. 779-787, 2008.

QIU, K.; NETRAVALI, A. N. A review of fabrication and applications of bacterial cellulose based nanocomposites. Polymer Reviews, v. 54, n. 4, p. 598-626, 2014.

RAMAKRISHNA, S.; RAMASESHAN, R. Battlefield filtration. Chemical Engineer, n. 809, p. 34-36, 2008.

RAMIRES, E. C.; DE OLIVEIRA, F.; FROLLINI, E. Composites based on renewable materials: Polyurethane-type matrices from forest byproduct/vegetable oil and reinforced with lignocellulosic fibers. Journal of Applied Polymer Science, v. 129, n. 4, p. 2224-2233, 2013.

RAMIRES, E. C.; FROLLINI, E. Tannin-phenolic resins: Synthesis, characterization, and application as matrix in biobased composites reinforced with sisal fibers. Composites Part B: Engineering, v. 43, n. 7, p. 2851-2860, 2012.

RAMOS, L.; MORGADO, D.; EL SEOUD, O.; DA SILVA, V.; FROLLINI, E. Acetylation of cellulose in licl-n,n -dimethylacetamide: First report on the correlation between the reaction efficiency and the aggregation number of dissolved cellulose. Cellulose, v. 18, n. 2, p. 385$392,2011$.

RAMOS, L. A.; ASSAF, J. M.; EL SEOUD, O. A.; FROLLINI, E. Influence of the supramolecular structure and physicochemical properties of cellulose on its dissolution in a lithium chloride/n,n-dimethylacetamide solvent system. Biomacromolecules, v. 6, n. 5, p. 2638-2647, 2005.

RAMOS, L. A.; MORGADO, D. L.; GESSNER, F.; FROLLINI, E.; EL SEOUDB, O. A. A physical organic chemistry approach to dissolution of cellulose: Effects of cellulose mercerization on its properties and on the kinetics of its decrystallization. Arkivoc, v. 2011, n. 7, p. 416-425, 2011. 
RATANAKAMNUAN, U.; MANOROM, W.; INTHASAI, P. Preparation of biodegradable film from esterified corn husk cellulose. Advanced Materials Research, v. 701, p. 229-233, 2013.

RAZERA, I. A. T. Fibras lignocelulósicas como agente de reforço de compósitos de matriz fenólica e lignofenólica. 2006. 168f. (Doutorado) - Instituto de Química de São Carlos, Universidade de São Paulo, São Carlos, 2006.

REDDY, N.; YANG, Y. Biofibers from agricultural byproducts for industrial applications. Trends in Biotechnology, v. 23, n. 1, p. 22-27, 2005.

REGIANI, A. M.; FROLLINI, E.; MARSON, G. A.; GUILHERME, M.; SEOUD, O. A. E. L. Some aspects of acylation of cellulose under homogeneous solution conditions. Journal of Polymer Science, Part A: Polymer Chemistry, v. 37, n. 9, p. 1357-1363, 1999.

RÖDER, T.; MORGENSTERN, B.; SCHELOSKY, N.; GLATTER, O. Solutions of cellulose in $\mathrm{n}, \mathrm{n}$-dimethylacetamide/lithium chloride studied by light scattering methods. Polymer, v. 42, n. 16, p. 6765-6773, 2001.

RODRIGUES, B. V. M.; HEIKKILÄ, E.; FROLLINI, E.; FARDIM, P. Multi-technique surface characterization of bio-based films from sisal cellulose and its esters: A fe-sem, $\mu$-xps and tof-sims approach. Cellulose, v. 21, n. 3, p. 15, 2014.

ROSENBERG, P.; SUOMINEN, I.; ROM, M.; JANICKI, J.; FARDIM, P. Tailored cellulose beads for novel applications. Cellulose Chemistry and Technology, v. 41, n. 4-6, p. 243 254, 2007.

ROY, C.; BUDTOVA, T.; NAVARD, P. Rheological properties and gelation of aqueous cellulose-naoh solutions. Biomacromolecules, v. 4, n. 2, p. 259-264, 2003.

SAIRAM, M.; SREEDHAR, B.; MOHAN RAO, D. V.; PALANIAPPAN, S. Synthesis and thermal degradation kinetics of cellulose esters. Polymers for Advanced Technologies, v. 14, n. 7, p. 477-485, 2003.

SAITO, K.; KATO, T.; TAKAMORI, H.; KISHIMOTO, T.; FUKUSHIMA, K. A new analysis of the depolymerized fragments of lignin polymer using tof-sims.

Biomacromolecules, v. 6, n. 5, p. 2688-2696, 2005.

SAITO, K.; KATO, T.; TSUJI, Y.; FUKUSHIMA, K. Identifying the characteristic secondary ions of lignin polymer using tof-sims. Biomacromolecules, v. 6, n. 2, p. 678-683, 2005.

SAITO, T.; HIROTA, M.; TAMURA, N.; KIMURA, S.; FUKUZUMI, H.; HEUX, L.; ISOGAI, A. Individualization of nano-sized plant cellulose fibrils by direct surface carboxylation using tempo catalyst under neutral conditions. Biomacromolecules, v. 10, n. 7 , p. 1992-1996, 2009.

SASSI, J. F.; CHANZY, H. Ultrastructural aspects of the acetylation of cellulose. Cellulose, v. 2, n. 2, p. 111-127, 1995. 
SCHEIRS, J.; CAMINO, G.; TUMIATTI, W. Overview of water evolution during the thermal degradation of cellulose. European Polymer Journal, v. 37, n. 5, p. 933-942, 2001.

SCHMIDT, S.; LIEBERT, T.; HEINZE, T. Synthesis of soluble cellulose tosylates in an ecofriendly medium. Green Chemistry, v. 16, n. 4, p. 1941-1946, 2014.

SCHULZ, L.; SEGER, B.; BURCHARD, W. Structures of cellulose in solution. Macromolecular Chemistry and Physics, v. 201, n. 15, p. 2008-2022, 2000.

SCHWANNINGER, M.; RODRIGUES, J. C.; PEREIRA, H.; HINTERSTOISSER, B. Effects of short-time vibratory ball milling on the shape of ft-ir spectra of wood and cellulose.

Vibrational Spectroscopy, v. 36, n. 1, p. 23-40, 2004.

SHEN, D. K.; GU, S. The mechanism for thermal decomposition of cellulose and its main products. Bioresour Technol, v. 100, n. 24, p. 6496-504, 2009.

SIBANI, B.; SANDHYAMAYEE, S.; SABITA, P.; BIJAY, M. K. Sisal fiber: A potential raw material for handmade paper. Indian Pulp and Paper Technical Association, v. 24, n. 2, p. $8,2012$.

SON, W. K.; YOUK, J. H.; LEE, T. S.; PARK, W. H. Electrospinning of ultrafine cellulose acetate fibers: Studies of a new solvent system and deacetylation of ultrafine cellulose acetate fibers. Journal of Polymer Science, Part B: Polymer Physics, v. 42, n. 1, p. 5-11, 2004a.

SON, W. K.; YOUK, J. H.; LEE, T. S.; PARK, W. H. Preparation of antimicrobial ultrafine cellulose acetate fibers with silver nanoparticles. Macromolecular Rapid Communications, v. 25 , n. 18 , p. 1632-1637, 2004 b.

SOYKEABKAEW, N.; SIAN, C.; GEA, S.; NISHINO, T.; PEIJS, T. All-cellulose nanocomposites by surface selective dissolution of bacterial cellulose. Cellulose, v. 16, n. 3 , p. 435-444, 2009.

SPIRIDON, I.; POPA, V. I. Hemicelluloses: Major sources, properties and applications. In: GANDINI, A.; BELGACEM, M. N. (Ed.). Monomers, polymers and composites from renewable resources. Amsterdam: Elsevier, 2008. p. 289-304.

STAMM, A. J.; TARKOW, H. Penetration of cellulose fibers. Journal of Physics Colloid Chemistry, v. 54, n. 6, p. 745-53, 1950.

SUN, J. X.; SUN, X. F.; SUN, R. C.; SU, Y. Q. Fractional extraction and structural characterization of sugarcane bagasse hemicelluloses. Carbohydrate Polymers, v. 56, n. 2, p. 195-204, 2004.

SUN, R. C.; SUN, X. F. Fractional and structural characterization of hemicelluloses isolated by alkali and alkaline peroxide from barley straw. Carbohydrate Polymers, v. 49, n. 4, p. 415-423, 2002.

TAO, S. L.; DESAI, T. A. Aligned arrays of biodegradable poly( $\varepsilon$-caprolactone) nanowires and nanofibers by template synthesis. Nano Letters, v. 7, n. 6, p. 1463-1468, 2007. 
TAPPI, P. Surface wettability of paper. 1994.

TASHIRO, K.; KOBAYASHI, M. Theoretical evaluation of three-dimensional elastic constants of native and regenerated celluloses: Role of hydrogen bonds. Polymer, v. 32, n. 8, p. 1516-1526, 1991.

TAUBNER, T.; ČOPÍKOVÁ, J.; HAVELKA, P.; SYNYTSYA, A. Preparation of amidated derivatives of monocarboxy cellulose. Cellulose, v. 20, n. 4, p. 2045-2055, 2013.

TERBOJEVICH, M.; COSANI, A.; CONIO, G.; CIFERRI, A.; BLANCHI, E. Mesophase formation and chain rigidity in cellulose and derivatives. 3. Aggregation of cellulose in n,ndimethylacetamide-lithium chloride. Macromolecules, v. 18, n. 4, p. 640-646, 1985.

THAKKER, S. P.; ROKHADE, A. P.; ABBIGERIMATH, S. S.; ILIGER, S. R.; KULKARNI, V. H.; MORE, U. A.; AMINABHAVI, T. M. Inter-polymer complex microspheres of chitosan and cellulose acetate phthalate for oral delivery of 5-fluorouracil. Polymer Bulletin, v. 71, n. 8, p. 2113-2131, 2014.

THAKUR, V. K.; THAKUR, M. K.; RAGHAVAN, P.; KESSLER, M. R. Progress in green polymer composites from lignin for multifunctional applications: A review. ACS Sustainable Chemistry \& Engineering, v. 2, n. 5, p. 1072-1092, 2014.

THIRIPURA SUNDARI, M.; RAMESH, A. Isolation and characterization of cellulose nanofibers from the aquatic weed water hyacinth-eichhornia crassipes. Carbohydrate Polymers, v. 87, n. 2, p. 1701-1705, 2012.

TOKAREVA, E. N.; FARDIM, P.; PRANOVICH, A. V.; FAGERHOLM, H. P.; DANIEL, G.; HOLMBOM, B. Imaging of wood tissue by tof-sims: Critical evaluation and development of sample preparation techniques. Applied Surface Science, v. 253, n. 18, p. 7569-7577, 2007.

TOKAREVA, E. N.; PRANOVICH, A. V.; FARDIM, P.; DANIEL, G.; HOLMBOM, B. Analysis of wood tissues by time-of-flight secondary ion mass spectrometry. Holzforschung, v. 61, n. 6, p. 647-655, 2007.

TOKAREVA, E. N.; PRANOVICH, A. V.; HOLMBOM, B. R. Characteristic fragment ions from lignin and polysaccharides in tof-sims. Wood Science and Technology, v. 45, n. 4, p. 767-785, 2011.

TORIZ, G.; ARVIDSSON, R.; WESTIN, M.; GATENHOLM, P. Novel cellulose esterpoly(furfuryl alcohol)-flax fiber biocomposites. Journal of Applied Polymer Science, v. 88, n. 2, p. 337-345, 2003.

TRYGG, J.; FARDIM, P. Enhancement of cellulose dissolution in water-based solvent via ethanol-hydrochloric acid pretreatment. Cellulose, v. 18, n. 4, p. 987-994, 2011.

TRYGG, J.; FARDIM, P.; GERICKE, M.; MÄKILÄ, E.; SALONEN, J. Physicochemical design of the morphology and ultrastructure of cellulose beads. Carbohydrate Polymers, v. 93, n. 1, p. 291-299, 2012. 
TRYGG, J.; YILDIR, E.; KOLAKOVIC, R.; SANDLER, N.; FARDIM, P. Anionic cellulose beads for drug encapsulation and release. Cellulose, v. 21, n. 3, p. 1945-1955, 2014.

TURBAK, A. F. Recent developments in cellulose solvent systems. Tappi Journal, v. 67, n. 1, p. 94-96, 1984.

TURBAK, A. F. E.-K., A.; SNYDER, F. W.; AUERBACH, A. B. Solvent system for cellulose. US n.4302252A, 24 nov 1981.

VAN EIJCK, J.; BATIDZIRAI, B.; FAAIJ, A. Current and future economic performance of first and second generation biofuels in developing countries. Applied Energy, v. 135, p. 115$141,2014$.

VICKERMAN, J. C. Molecular sims - a journey from single crystal to biological surface studies. Surface Science, v. 603, n. 10-12, p. 1926-1936, 2009.

VIJAYALAKSHMI, K.; GOMATHI, T.; SUDHA, P. N. Preparation and characterization of nanochitosan/sodium alginate/microcrystalline cellulose beads. Der Pharmacia Lettre, v. 6, n. 4, p. 65-77, 2014.

VIJU, S. Medical applications of electrospun nanofibers. Technische Textilien, v. 52, n. 1, p. E16-E17, 2009.

VINCENDON, M. 1h nmr study of the chitin dissolution mechanism. Die Makromolekulare Chemie, v. 186, n. 9, p. 1787-1795, 1985.

VOLKERT, B.; WOLF, B.; FISCHER, S.; LI, N.; LOU, C. Application of modified bead cellulose as a carrier of active ingredients. Macromolecular Symposia, v. 280, n. 1, p. 130$135,2009$.

WALKER, J. C. F. Basic wood chemistry and cell wall ultrastructure. In: WALKER, J. C. F.; BUTTERFIELD, B. G.; HARRIS, J. M.; LANGRISH, T. A. G.; UPRICHARD, J. M. (Ed.). Primary wood processing. New York: Springer 2006. p. 23-67.

WANG, B.; RUAN, X.; CHEN, L.; CHEN, J.; YANG, Y. Heterogeneous chemical modification of cotton cellulose with vinyl sulfone dyes in non-nucleophilic organic solvents. Industrial \& Engineering Chemistry Research, v. 53, n. 41, p. 15802-15810, 2014.

WANG, H.; SHAO, Z.; BACHER, M.; LIEBNER, F.; ROSENAU, T. Fluorescent cellulose aerogels containing covalently immobilized (zns)x(cuins2)1-x/zns (core/shell) quantum dots. Cellulose, v. 20, n. 6, p. 3007-3024, 2013.

WANG, W.; CAO, J.; LAN, P.; WU, W. Drug release from electrospun fibers of poly(3hydroxybutyrate-co-3- hydroxyvalerate) grafted with poly(n-vinylpyrrolidone). Journal of Applied Polymer Science, v. 124, n. 3, p. 1919-1928, 2012.

WARWICKER, J. O.; SPEDDING, H. Effect of chemical agents on the fine structure of cellulose. Part ii. The action of acetyl chloride. Journal of Applied Polymer Science, v. 9, n. 5, p. 1913-1928, 1965. 
WETTON, R. Dynamic mechanical thermal analysis of polymers and related systems. In: DAWKINS, J. V. (Ed.). Developments in polymer characterization. London: Elsevier Applied Science Publishers, 1986. p. 179-221.

WHITESIDES, G. M.; GRZYBOWSKI, B. Self-assembly at all scales. Science, v. 295, n. 5564, p. 2418-2421, 2002.

WIEDERSCHAIN, G. Y. Polysaccharides. Structural diversity and functional versatility. Biochemistry (Moscow), v. 72, n. 6, p. 675-675, 2007.

WU, R.; HE, B.; ZHANG, B.; ZHAO, G.; LI, J.; LI, X. Preparation of immobilized pectinase on regenerated cellulose beads for removing anionic trash in whitewater from papermaking. Journal of Chemical Technology \& Biotechnology, v. 89, n. 7, p. 1103-1109, 2014.

WU, R. L.; WANG, X. L.; LI, F.; LI, H. Z.; WANG, Y. Z. Green composite films prepared from cellulose, starch and lignin in room-temperature ionic liquid. Bioresource Technology, v. 100, n. 9, p. 2569-2574, 2009.

XIAO, B.; SUN, X. F.; SUN, R. Chemical, structural, and thermal characterizations of alkalisoluble lignins and hemicelluloses, and cellulose from maize stems, rye straw, and rice straw.

Polymer Degradation and Stability, v. 74, n. 2, p. 307-319, 2001.

XIONG, B.; ZHAO, P.; HU, K.; ZHANG, L.; CHENG, G. Dissolution of cellulose in aqueous naoh/urea solution: Role of urea. Cellulose, v. 21, n. 3, p. 1183-1192, 2014.

XU, Y.; WANG, C.; STARK, N. M.; CAI, Z.; CHU, F. Miscibility and thermal behavior of poly ( $\varepsilon$-caprolactone)/long-chain ester of cellulose blends. Carbohydrate Polymers, v. 88, n. 2, p. 422-427, 2012.

YAN, J.; HORAK, D.; LENFELD, J.; HAMMOND, M.; KAMALI-MOGHADDAM, M. A tosyl-activated magnetic bead cellulose as solid support for sensitive protein detection. $\mathbf{J}$

Biotechnol, v. 167, n. 3, p. 235-40, 2013.

YAN, L.; ZHU, Q. Direct observation of the fringed micelles structure of cellulose molecules solvated in dimethylacetamide/licl system. Polymer International, v. 51, n. 8, p. 738-739, 2002.

YILDIR, E.; KOLAKOVIC, R.; GENINA, N.; TRYGG, J.; GERICKE, M.; HANSKI, L.; EHLERS, H.; RANTANEN, J.; TENHO, M.; VUORELA, P.; FARDIM, P.; SANDLER, N. Tailored beads made of dissolved cellulose - investigation of their drug release properties. International Journal of Pharmaceutics, v. 456, n. 2, p. 417-423, 2013.

YUAN, Y. M.; LI, Q. J.; YAO, S. K.; ZHANG, W.; ZHANG, J. F. Immobilization of papain on regenerated cellulose from ionic liquids. Applied Mechanics and Materials, v. 448-453, p. 1651-1655, 2014.

ZHANG, C.; LIU, R.; XIANG, J.; KANG, H.; LIU, Z.; HUANG, Y. Dissolution mechanism of cellulose in n,n-dimethylacetamide/lithium chloride: Revisiting through molecular interactions. The Journal of Physical Chemistry B, v. 118, n. 31, p. 9507-9514, 2014. 
ZHANG, D.; XIE, J.; YU, P.; HUANG, X.; YANG, M.; LIU, H. Antifungal activity and humidity sensitivity of quaternized cellulose synthesized in naoh/urea aqueous solution. Cellulose, v. 19, n. 1, p. 189-198, 2012.

ZHANG, K.; FISCHER, S.; GEISSLER, A.; BRENDLER, E. Analysis of carboxylate groups in oxidized never-dried cellulose ii catalyzed by tempo and 4-acetamide-tempo.

Carbohydrate Polymers, v. 87, n. 1, p. 894-900, 2012.

ZHANG, L.; RUAN, D.; GAO, S. Dissolution and regeneration of cellulose in naoh/thiourea aqueous solution. Journal of Polymer Science, Part B: Polymer Physics, v. 40, n. 14, p. 1521-1529, 2002.

ZHANG, L.; RUAN, D.; ZHOU, J. Structure and properties of regenerated cellulose films prepared from cotton linters in naoh/urea aqueous solution. Industrial and Engineering Chemistry Research, v. 40, n. 25, p. 5923-5928, 2001.

ZHANG, Q. L.; SHI, F.; WANG, P.; LIN, D. Q.; YAO, S. J. Preparation of cellulose adsorbents with ionic liquid and pore expansion for chromatographic applications. Journal of Applied Polymer Science, v. 131, n. 7, p., 2014.

ZHANG, X.; LI, J.; YANG, W.; BLASIAK, W. Formation mechanism of levoglucosan and formaldehyde during cellulose pyrolysis. Energy \& Fuels, v. 25, n. 8, p. 3739-3746, 2011.

ZHAO, M.; XU, X. L.; JIANG, Y. D.; SUN, W. Z.; WANG, W. F.; YUAN, L. M. Enantioseparation of trans-stilbene oxide using a cellulose acetate membrane. Journal of Membrane Science, v. 336, n. 1-2, p. 149-153, 2009.

ZHOU, D.; ZHANG, L.; GUO, S. Mechanisms of lead biosorption on cellulose/chitin beads. Water Research, v. 39, n. 16, p. 3755-3762, 2005.

ZHOU, D.; ZHANG, L.; ZHOU, J.; GUO, S. Cellulose/chitin beads for adsorption of heavy metals in aqueous solution. Water Research, v. 38, n. 11, p. 2643-2650, 2004.

ZHOU, H.-Y.; CHEN, X.-G. Characteristics and degradation of chitosan/cellulose acetate microspheres with different model drugs. Frontiers of Materials Science in China, v. 2, n. 4, p. 417-425, 2008.

ZHOU, J.; ZHANG, L. Solubility of cellulose in naoh/urea aqueous solution. Polymer Journal, v. 32, n. 10, p. 866-870, 2000.

ZHOU, J.; ZHANG, L.; CAI, J.; SHU, H. Cellulose microporous membranes prepared from naoh/urea aqueous solution. Journal of Membrane Science, v. 210, n. 1, p. 77-90, 2002.

ZHOU, Q.; ZHANG, L.; LI, M.; WU, X.; CHENG, G. Homogeneous hydroxyethylation of cellulose in naoh/urea aqueous solution. Polymer Bulletin, v. 53, n. 4, p. 243-248, 2005.

ZHUANG, X.; MAI, Y.; WU, D.; ZHANG, F.; FENG, X. Two-dimensional soft nanomaterials: A fascinating world of materials. Advanced Materials, p., 2014. 
ZUGENMAIER, P. History of cellulose research. In: ZUGENMAIER, P. (Ed.). Crystalline cellulose and derivatives. Berlin: Springer 2008. p. 7-51. 